\title{
Functional effects of the MICA-129 dimorphism on NK cell activity and association with the outcome of hematopoietic stem cell transplantation
}

\author{
Doctoral Thesis \\ In partial fulfillment of the requirements for the degree \\ "Doctor rerum naturalium (Dr. rer. nat.)“ \\ in the Molecular Medicine Study Program \\ at the Georg-August-University Göttingen
}

submitted by

Antje Isernhagen

born in

Winsen/Luhe, Germany

Göttingen, February 2014 


\section{Members of the thesis committee}

Supervisor and first member of the thesis committee:

Prof. Dr. Lutz Walter

Department of Primate Genetics

German Primate Center Göttingen

Second member of the thesis committee:

Prof. Dr. Heidi Hahn

Department of Human Genetics

Georg-August-University Göttingen

Third member of the thesis committee:

$\underline{\text { Prof. Dr. Ralf Dressel }}$

Department of Cellular and Molecular Immunology

Georg-August-University Göttingen

Date of Disputation: 


\section{Affidavit}

Here I declare that my doctoral thesis entitled

"Functional effects of the MICA-129 dimorphism on NK cell activity and association with the outcome of hematopoietic stem cell transplantation"

has been written independently with no other sources and aids than quoted. This thesis has not been submitted elsewhere for any academic degree.

Antje Isernhagen

February 2014

Göttingen, Germany 


\section{Table of contents}

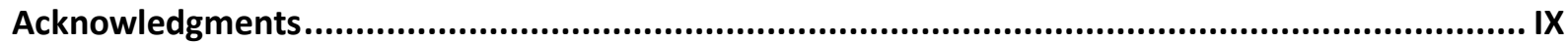

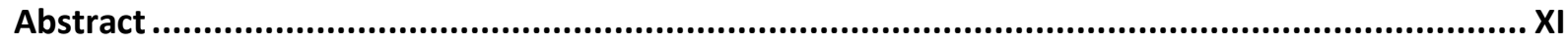

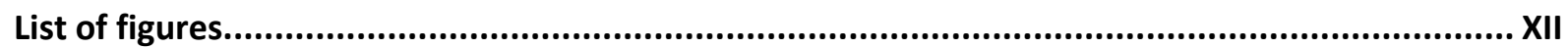

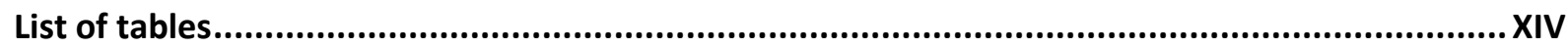

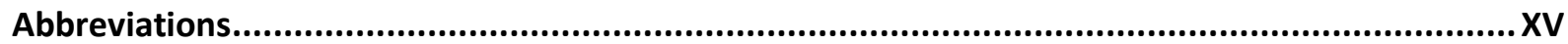

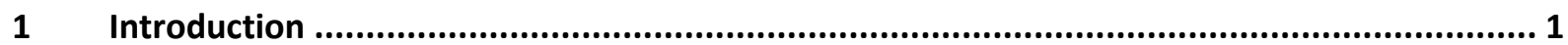

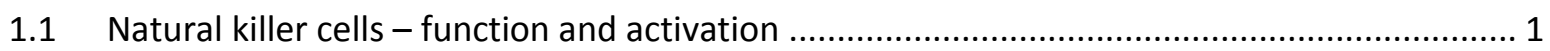

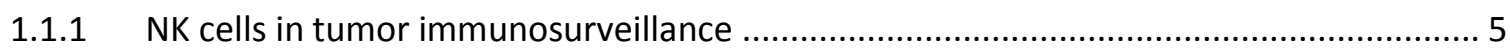

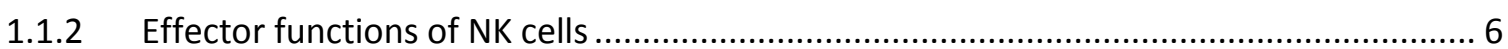

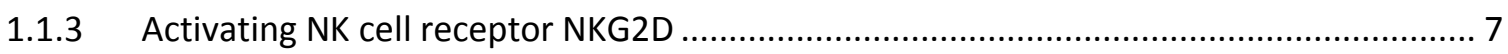

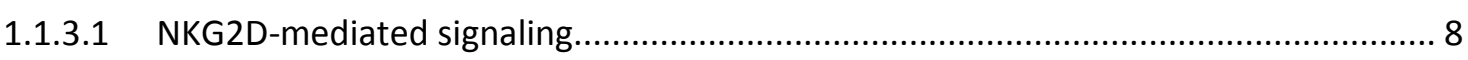

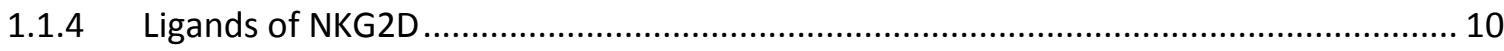

1.1.4.1 Regulation of NKG2D ligand expression ................................................................. 11

1.1.5 Tumor immune evasion - NKG2D down-regulation and MICA shedding ....................... 12

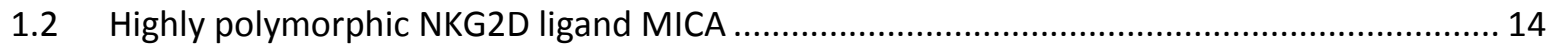

1.2.1 MICA structure and MICA-NKG2D interaction ........................................................... 15

1.2.2 MICA polymorphisms - MICA-129Met/Val dimorphism ............................................ 16

1.2.3 Associations of MICA polymorphisms with diseases ..................................................... 17

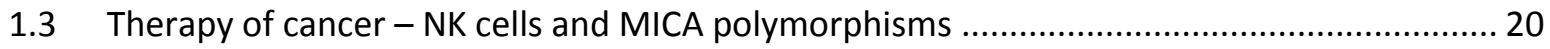

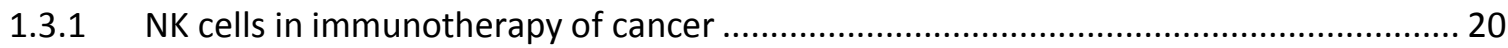

1.3.2 Targeting of NKG2D or its ligands for cancer therapy ................................................ 22

1.3.3 Importance of MICA polymorphisms in HSCT .................................................................. 23

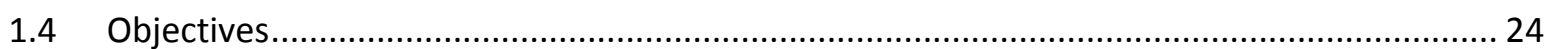

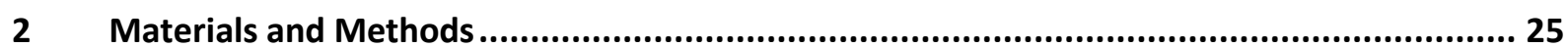

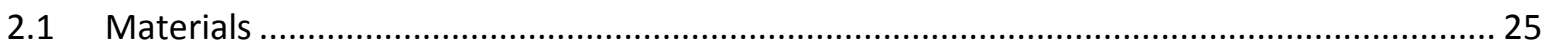

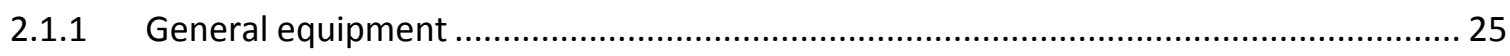

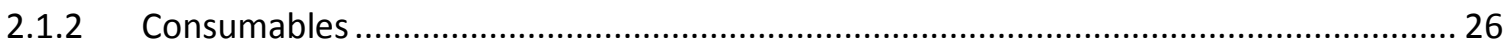

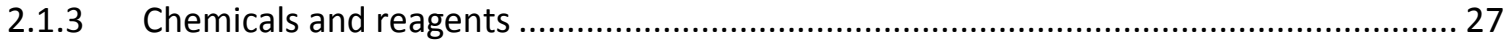

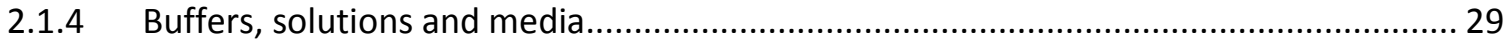

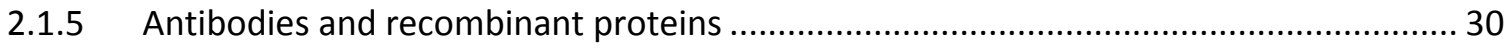

2.1.5.1 Primary and secondary antibodies for flow cytometry .......................................... 30 
2.1.5.2 Primary and secondary antibodies for western blot analysis ............................... 31

2.1.5.3 Antibodies for enzyme-linked immunosorbent assay (ELISA) ................................. 32

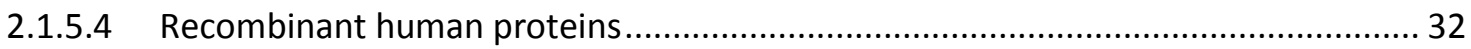

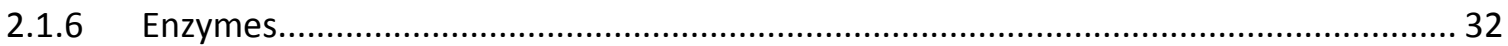

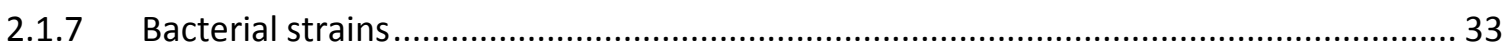

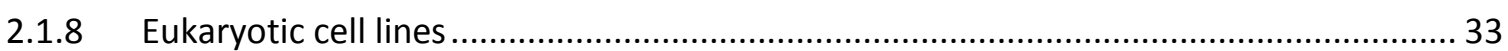

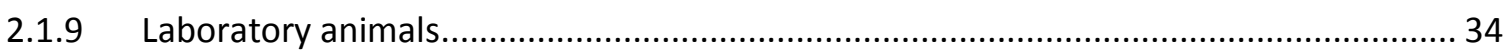

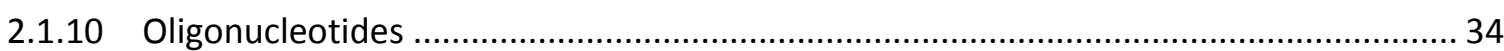

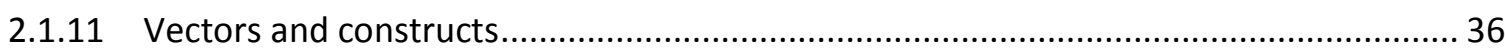

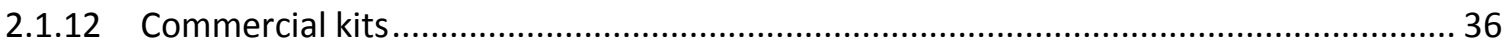

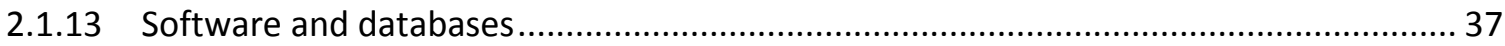

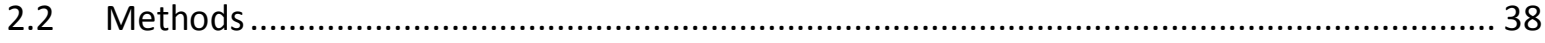

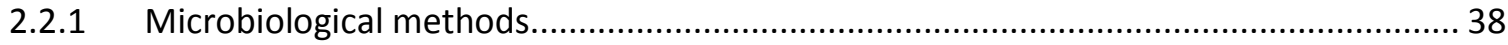

2.2.1.1 Transformation of chemo-competent E. coli .......................................................... 38

2.2.1.2 Culture and storage of chemo-competent E. coli .................................................. 38

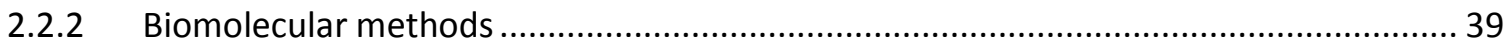

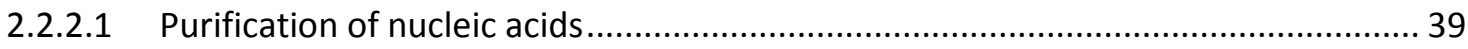

2.2.2.1.1 Extraction of nucleic acids from agarose gels ................................................ 39

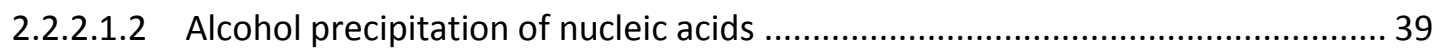

2.2.2.1.3 Phenol-chloroform extraction of nucleic acids ................................................. 39

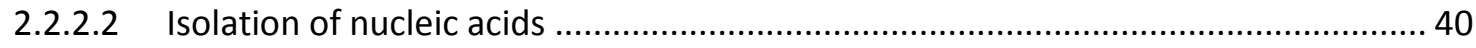

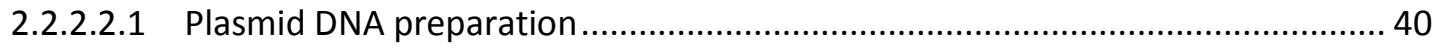

2.2.2.2.2 Genomic DNA preparation ................................................................................ 40

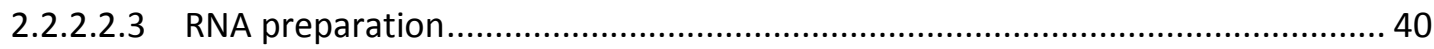

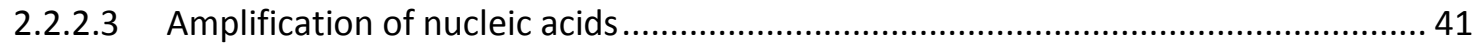

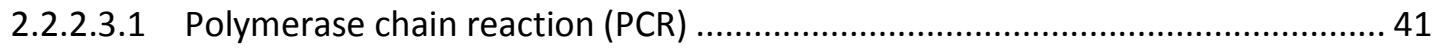

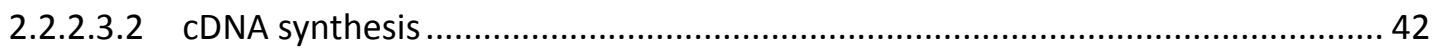

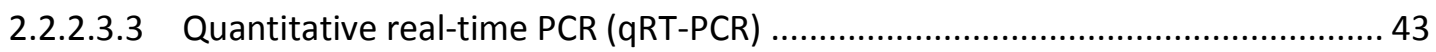

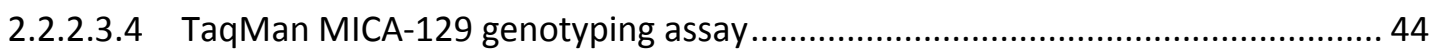

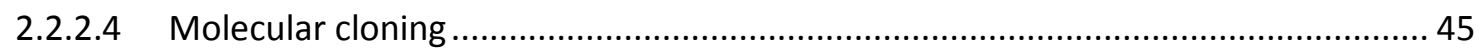

2.2.2.4.1 Restriction endonuclease digestion of nucleic acids........................................ 45

2.2.2.4.2 Dephosphorylation of vector DNA ...................................................................... 45

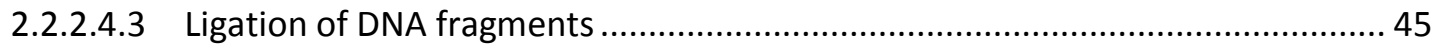




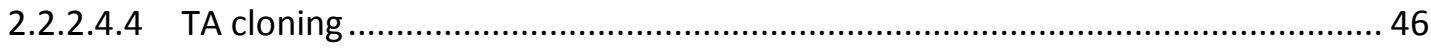

2.2.2.5 Agarose gel electrophoresis of nucleic acids.......................................................... 46

2.2.2.6 Photometric determination of nucleic acid concentration .................................... 47

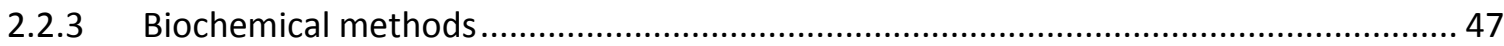

2.2.3.1 Production and purification of recombinant Fc-fusion proteins............................... 47

2.2.3.2 Bio-Rad protein assay for determination of protein concentration .......................... 48

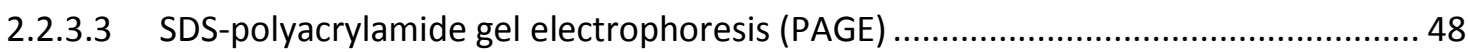

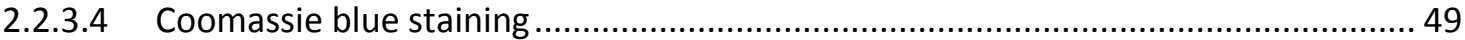

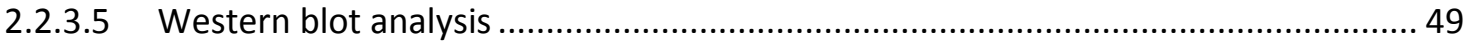

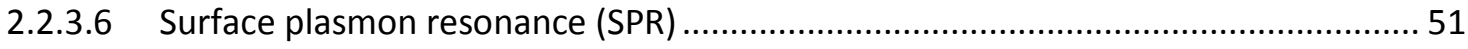

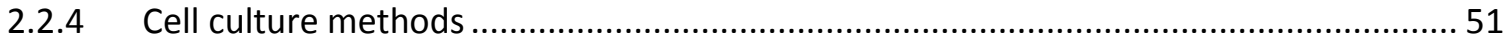

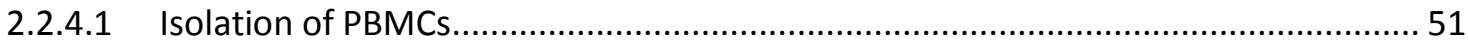

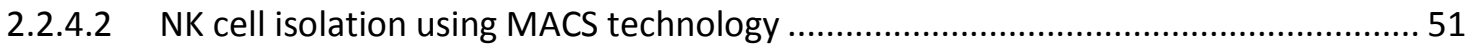

2.2.4.3 NK cell stimulation and production of NK cell lysates............................................ 52

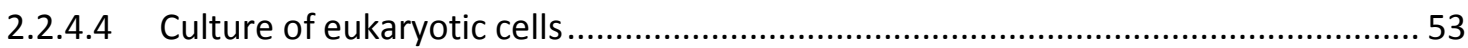

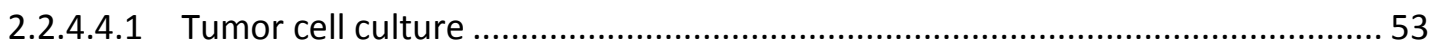

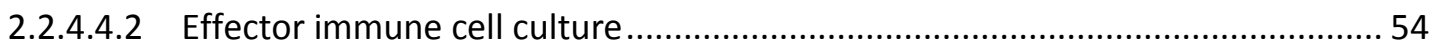

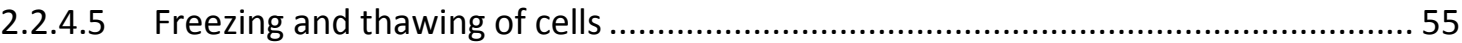

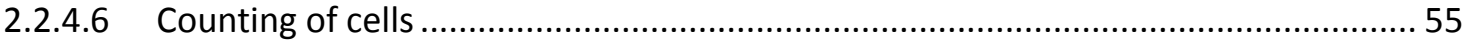

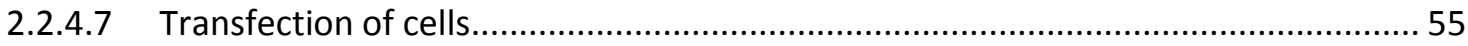

2.2.4.8 Cell culture for analysis of secreted proteins ........................................................... 56

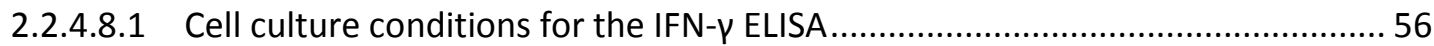

2.2.4.8.2 Cell culture conditions for the SMICA ELISA ........................................................ 57

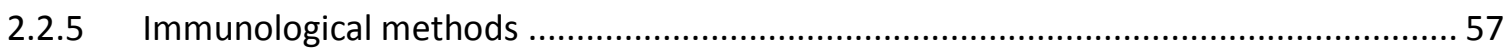

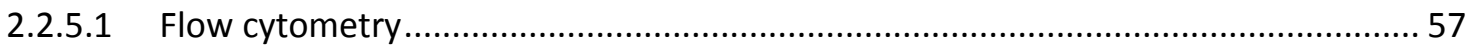

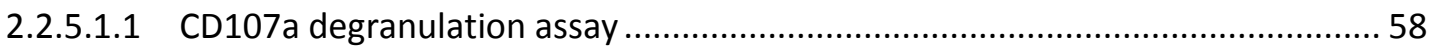

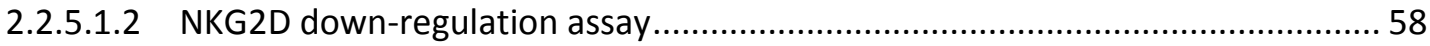

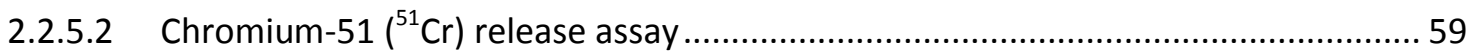

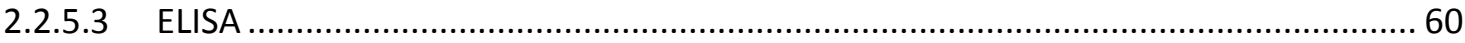

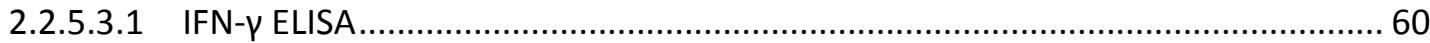

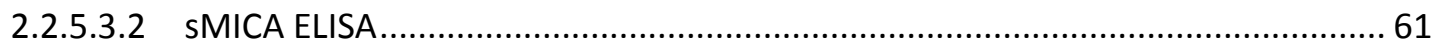

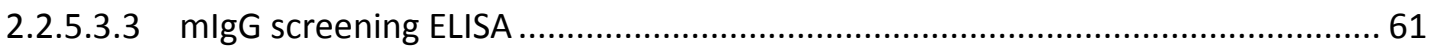

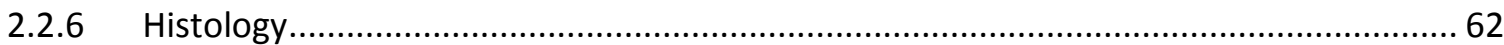




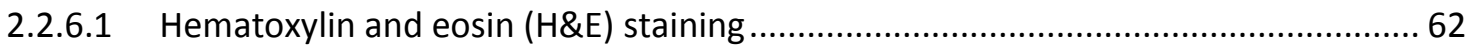

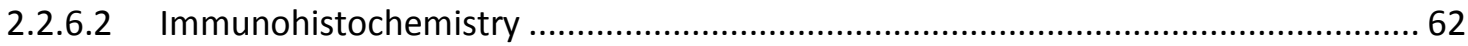

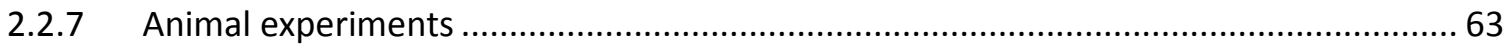

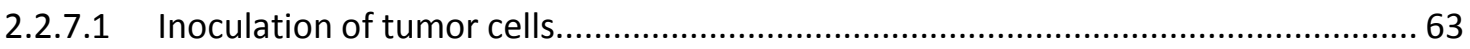

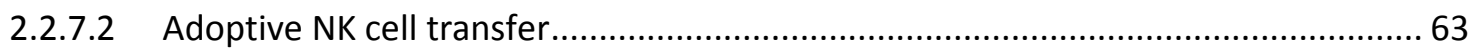

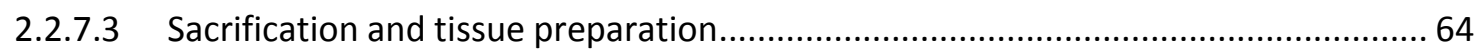

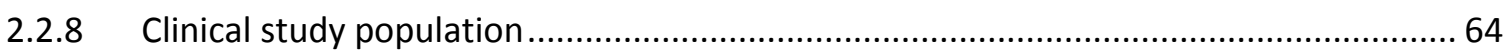

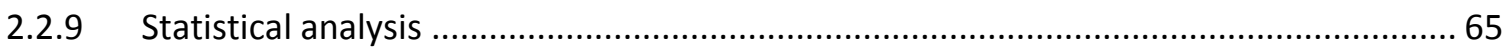

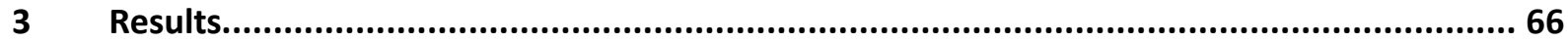

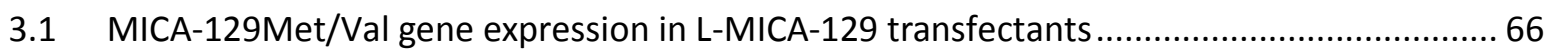

3.2 Influence of the MICA-129Met/Val polymorphism on binding avidity................................... 68

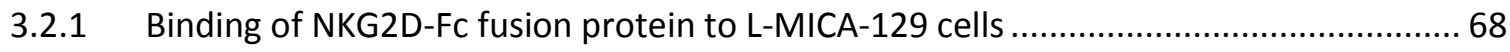

3.2.2 Binding of MICA-129-Fc fusion proteins to NKG2D of human NK cells .......................... 70

3.3 Functional effects of the MICA-129 dimorphism on human NK cells .................................... 75

3.3.1 Impact of the MICA-129 dimorphism on NKG2D-mediated signaling …........................ 75

3.3.2 Influence of the MICA-129 dimorphism on NK cell cytotoxicity .................................... 78

3.3.2.1 Degranulation of NK cells after stimulation with MICA-129-Fc proteins ................... 78

3.3.2.2 Degranulation of NK cells after co-culture with L-MICA-129 targets......................... 79

3.3.2.3 Susceptibility of MICA-129-expressing targets to NK cell-mediated killing ............... 82

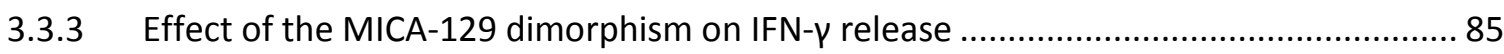

3.4 Impact of the MICA-129 dimorphism on MICA shedding and NKG2D counter-

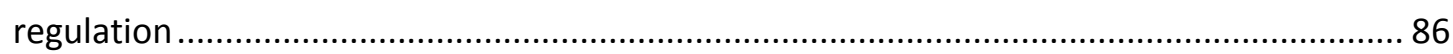

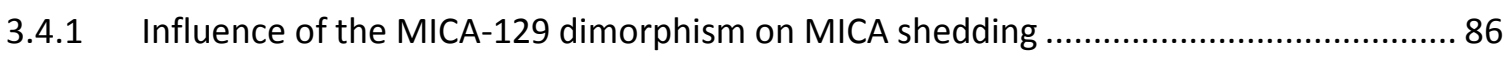

3.4.1.1 MICA shedding of mouse L-MICA-129-expressing cells ........................................... 86

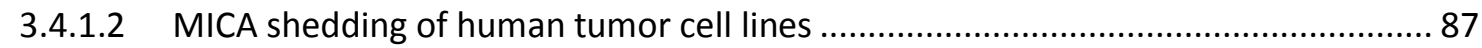

3.4.2 NKG2D down-regulation on NK cells after co-culture with L-MICA-129 cells ................ 90

3.5 Establishment of a mouse model for studying the impact of the MICA-129 dimorphism on an experimental adoptive immunotherapy of cancer .................................................... 92

3.5.1 Tumor growth after inoculation of L-MICA-129 cells................................................. 92

3.5.2 Adoptive NK cell therapy of L-MICA-129-bearing mice ................................................ 95

3.5.3 Optimization of NK cell stimulation for adoptive transfer ............................................. 96

3.6 Association of the MICA-129 dimorphism with survival and GVHD after HSCT .................... 98 
4.1 Different functional effects of the high and low avidity MICA-129Met/Val variant on NK cell activity

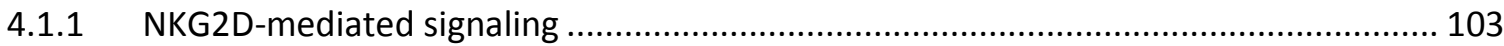

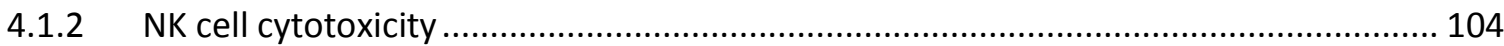

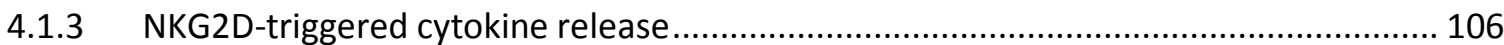

4.2 Influence of the MICA-129 dimorphism on MICA shedding and NKG2D counter-

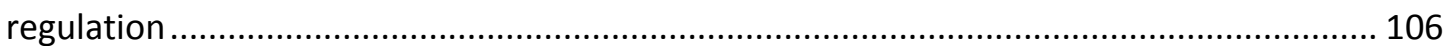

4.3 Association of the MICA-129 dimorphism with the outcome of HSCT ................................ 109

4.4 Open questions - MICA-129 gene expression and adoptive NK cell transfer ...................... 113

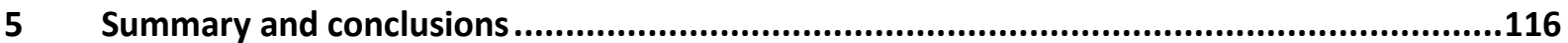

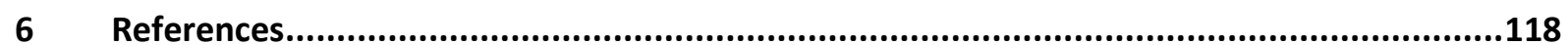

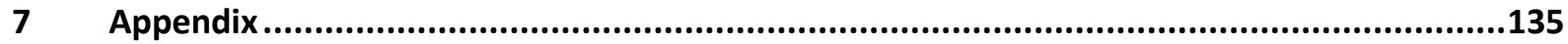

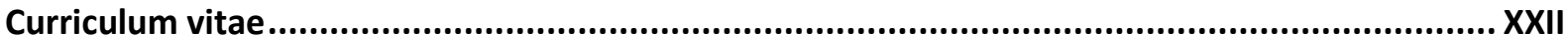




\section{Acknowledgments}

First, I would like to express my gratitude to Prof. Ralf Dressel from the Department of Cellular and Molecular Immunology of the University Medical Center Göttingen (UMG) for giving me the opportunity to accomplish my doctoral studies in his research group. I thank you for your competent advice, support and your confidence in me as scientist.

I sincerely thank Prof. Lutz Walter from the Department of Primate Genetics of the German Primate Center (DPZ) Göttingen for supervision of my work within the Ph.D. program Molecular Medicine, for very helpful suggestions and for providing reagents.

Many thanks also to Prof. Heidi Hahn from the Department of Human Genetics of the UMG for being member of my thesis committee and for following my project with great interest and stimulating discussions during thesis committee meetings.

I also want to acknowledge our technical assistant Leslie Elsner for experimental support and technical help. Her many years work experience helped me in various situations.

Many thanks to Dr. Michael Engelke for his expert opinion regarding questions on signaling pathways.

Furthermore, I would like to offer my special thanks to Elena Viktorova, Dr. Dörthe Malzahn, Dr. Yesilda Balavarva and Prof. Heike Bickeböller from the Department of Genetic Epidemiology of the UMG for statistical analyses.

I also would like to thank Prof. Gerald Wulf, Prof. Dieter Kube, Frederike von Bonin and Janne Marieke Wermuth from the Department of Hematology and Medical Oncology of the UMG for providing clinical samples and data and for genotyping clinical samples.

I thank Markus Kilisch and Prof. Blanche Schwappach from the Department of Molecular Biology of the UMG for SPR analyses.

In addition, I owe thanks to the head of the Institute for Cellular and Molecular Immunology of the UMG Prof. Jürgen Wienands and the secretaries Ingrid Teuteberg, Rosemarie Döhne and Anika Schindler.

Thanks to Iliana Siamishi for the work on a control vector construct during a lab rotation of her master studies. 
Moreover, I would like to acknowledge the graduate school GRK1034 "The impact of inherited polymorphisms in oncology: From basic science to clinical application" for the great research training opportunities and the German Research Foundation (DFG) and the UMG of the Georg-AugustUniversity Göttingen for providing my stipend and financial support.

To all members of the research group of Prof. Dressel and all colleagues from the institute also many thanks, especially to Sebastian, Carina, Charlotte, Niklas, Kai, Marcel and Henrike.

Finally, I would like to thank my family and my best friends for their unconditional support, for being at my side through all ups and downs and for their trust in me and my work. 


\section{Abstract}

The MHC class I chain-related molecule A (MICA) is a highly polymorphic ligand for the activating natural killer (NK) cell receptor NKG2D (NK group 2, member D). The single nucleotide polymorphism (SNP) at position 454 ( $\rightarrow \rightarrow G$, rs1051792) leads to an amino acid substitution of methionine by valine (Met $\rightarrow$ Val) at position 129 in the $\alpha 2$ domain of the MICA protein. In this study, we evaluated how the MICA-129Met/Val polymorphism affects NK cell function and whether it is associated with the outcome after allogeneic hematopoietic stem cell transplantation (HSCT). Results of the functional analyses using transfected cell lines and recombinant proteins for both variants revealed differences between both MICA-129 variants. The MICA-129Met isoform was characterized by higher NKG2D binding avidity $(P=0.0016)$, faster and stronger NKG2D signaling, triggering of more NK cell cytotoxicity (granule exocytosis, $P=0.0174$; target cell lysis, $P=0.0044$ ) and interferon-gamma (IFNy) release $(P<0.0001)$ but also increased NKG2D down-regulation $(P \leq 0.0006)$. Especially at low MICA expression intensity, the Met variant had stronger functional effects than the Val variant. However, the degree of NK cell cytotoxicity and cytokine production increased steadily with expression intensity of the MICA-129Val variant, whereas an enhanced expression of the MICA129Met isoform had no or even a negative effect on NK cell function. These data demonstrate a strong interdependency of the MICA expression intensity and the MICA-129 genotype. To elucidate whether the differences between the MICA variants are indeed clinically relevant, the MICA-129 dimorphism was determined in a cohort of patients undergoing allogeneic HSCT in the Department of Hematology and Medical Oncology at the University Medical Center Göttingen (320 genotyped patient/donor (P/D) pairs with clinical characteristics). In recipients matched on the MICA-129 genotype, MICA-129Met variants increased the chance of survival $(P=0.0395)$ and reduced the risk to die due to acute graft-versus-host disease (aGVHD, $P=0.0117$ ), although homozygous carriers had an increased risk to experience this complication $(P=0.0361)$ after HSCT. Thus, the presence of the high avidity variant of MICA may lead to a favorable outcome of HSCT due to initially stronger NKG2D signaling followed, however, by a more rapid NKG2D counter-regulation. Taken together, these data indicate that the MICA-129Met/Val polymorphism is functionally relevant and fine-tunes NK cell activity suggesting that it has direct effects on the outcome of HSCT but the intensity of MICA expression is a major confounding factor. 


\section{List of figures}

Figure 1.1: Inhibitory receptors, activating receptors and adhesion or co-stimulation molecules of human NK cells.

Figure 1.2: Multiple signals control NK cell responses................................................................ 5

Figure 1.3: DAP10-mediated NKG2D signaling in human NK cells................................................... 9

Figure 1.4: Strategies of tumor immune escape from NK cell-mediated immunosurveillance............ 13

Figure 1.5: Exon/intron organization of the human MICA gene. .................................................... 14

Figure 1.6: Crystal structure of the human MICA-NKG2D complex and human MICA alone.............. 16

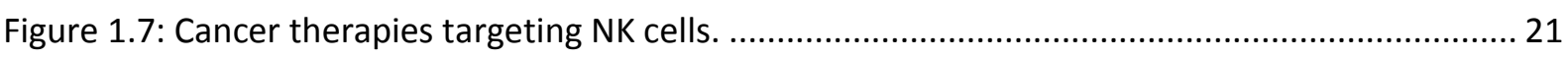

Figure 3.1: MICA mRNA expression significantly differs between the MICA-129Met and MICA129 Val variants.

Figure 3.2: L-MICA-129Met and L-MICA-129Val cells, in contrast to vector-only transfected L-con

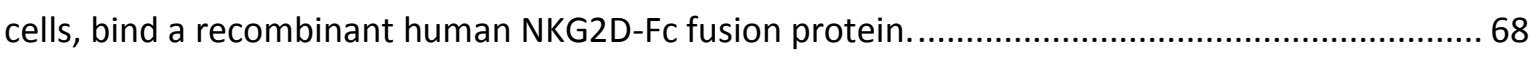

Figure 3.3: The MICA-129Met variant binds NKG2D with higher avidity than the MICA-129Val variant.

Figure 3.4: Identification of MICA-129Met-Fc, MICA-129Val-Fc and OVA-Fc fusion proteins.............. 71

Figure 3.5: Characterization of purified IL-2-stimulated human NK cells. .......................................... 72

Figure 3.6: MICA-129Met-Fc and MICA-129Val-Fc fusion proteins, but not OVA-Fc protein, bind to NKG2D of human NK cells.

Figure 3.7: MICA-129Met-Fc and MICA-129Val-Fc proteins bind with similar avidity to NKG2D-Fc in SPR analysis.

Figure 3.8: NKG2D-mediated phosphorylation of Src family kinases in response to the MICA$129 \mathrm{Met}-\mathrm{Fc}$ protein is stronger and faster than in response to the MICA-129Val-Fc protein.

Figure 3.9: The specific inhibitor PP2 inhibits phosphorylation of Src family kinases in response to

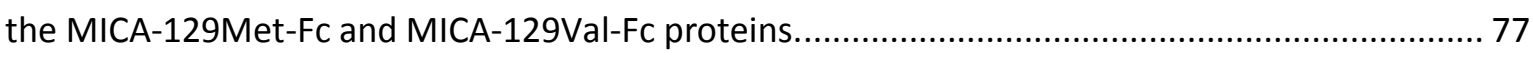

Figure 3.10: Degranulation of NK cells differs after stimulation with MICA-129Met-Fc and MICA129 Val-Fc proteins.

Figure 3.11: Granule exocytosis of NK cells exposed to MICA-129Met and MICA-129Valexpressing $L$ cells is significantly different and depends on the MICA expression level. 
Figure 3.12: Cytotoxicity of NK cells in response to the MICA-129Met and MICA-129Val isoforms significantly varies and depends on the MICA expression intensity.

Figure 3.13: IFN- $-\gamma$ release of NK cells in response to the MICA-129Met and MICA-129Val variants is significantly different

Figure 3.14: MICA cell surface expression of human tumor cell lines.

Figure 3.15: MICA shedding significantly differs between the MICA-129Met and MICA-129Val variants and is dependent on the MICA expression intensity.

Figure 3.16: Less NKG2D down-regulation on NK cells co-cultured with L-MICA-129Val cells compared to L-MICA-129Met cells.

Figure 3.17: Immunohistochemistry of non-invasive tumors after injection of L-MICA-129 and Lcon cells.

Figure 3.18: Expression of NK cell receptors and degranulation of NK cells after IL-12/15/18 preactivation

Figure 3.19: Genotyping for the MICA-129 dimorphism by an allele-specific TaqMan assay.

Figure 3.20: Cumulative survival according to the MICA-129 genotype

Figure 4.1: Functional effects of the MICA-129Met/Val dimorphism on NK cell activity and tumorassociated counter-regulation mechanisms.

Figure A.1: NKG2D-mediated phosphorylation of Src family kinases in response to the MICA129 Met-Fc protein is faster than in response to the MICA-129Val-Fc protein

Figure A.2: Proliferation of different mouse $L$ tumor cell lines in vitro.

Figure A.3: Co-culture of human NK cells and irradiated human allogeneic PBMCs ('feeder cells'). . 137 


\section{List of tables}

Table 1.1: Amino acid substitutions in extracellular domains of the human MICA protein.

Table 1.2: $\quad$ SNPs in MICA alleles associated with human diseases

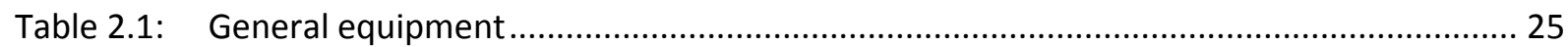

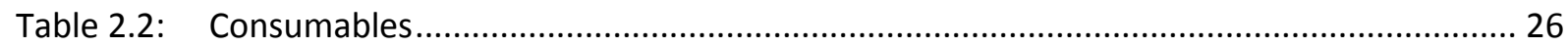

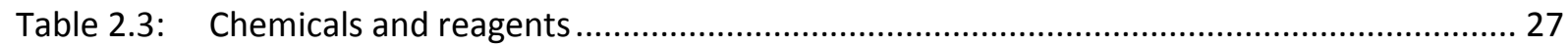

Table 2.4: Antibodies for flow cytometry ........................................................................ 30

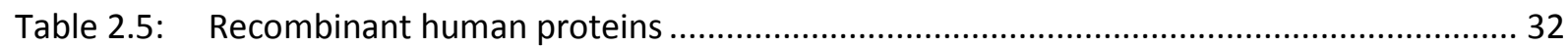

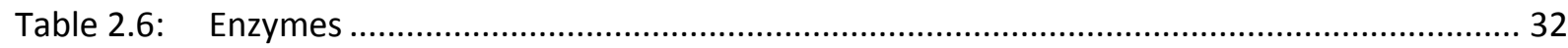

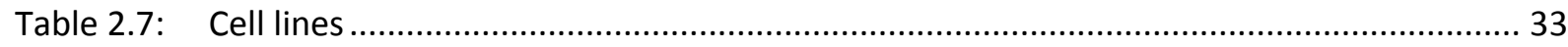

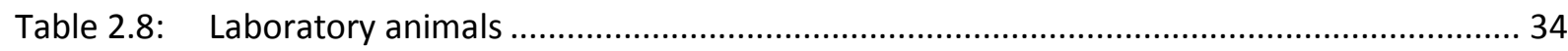

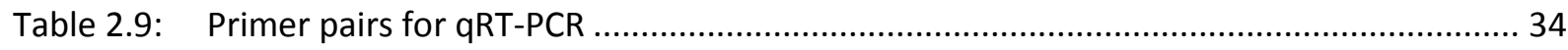

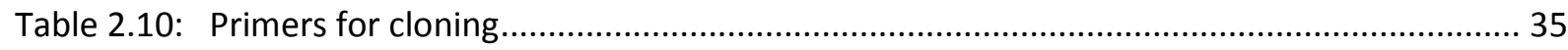

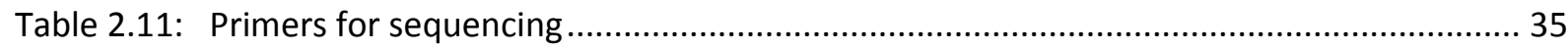

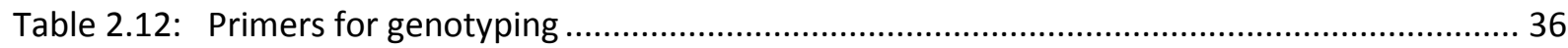

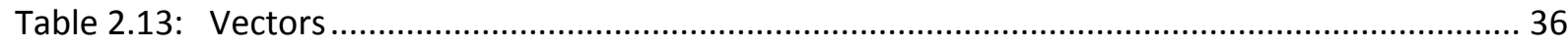

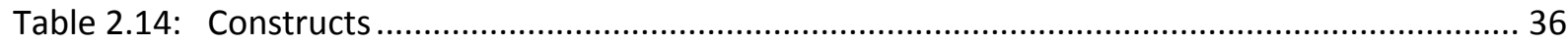

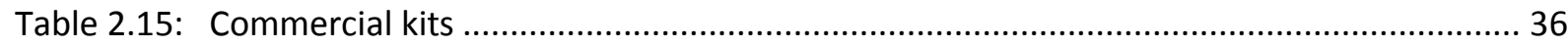

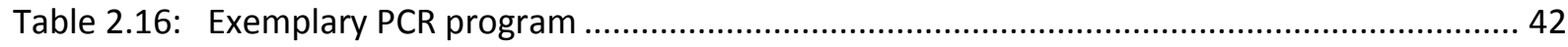

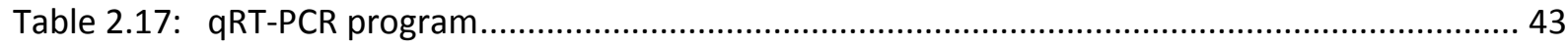

Table 3.1: $\quad$ Analysis of MICA shedding from L-MICA-129Met and L-MICA-129Val cells. ................ 87

Table 3.2: $\quad$ Tumor growth of different $L$ cell lines in immunodeficient mice. ................................ 93

Table 3.3: Tumor growth of different $L$ cell lines in immunodeficient C57BL/6-Rag2/-/cyc ${ }^{-/-}$mice.. 95

Table 3.4: HSCT pairs, diseases, transplantation characteristics and outcome. 99

Table A.1: Genotyping and analysis of the MICA mRNA expression of human tumor cell lines.... 138 


\section{Abbreviations}

\begin{tabular}{|c|c|}
\hline$\alpha$ & alpha \\
\hline$\alpha \beta$ TCR & alpha-beta T cell receptor \\
\hline$\beta$ & beta \\
\hline P & gamma \\
\hline $\delta$ TCR & gamma-delta T cell receptor \\
\hline$\delta / \Delta$ & delta \\
\hline$\mu$ & micro \\
\hline$\mu \mathrm{Ci}$ & microCurie \\
\hline$\mu F$ & microfarad \\
\hline$\mu g$ & microgram \\
\hline$\mu l$ & microliter \\
\hline$\mu \mathrm{m}$ & micrometer \\
\hline$\mu \mathrm{M}$ & micromolar \\
\hline$\zeta$ & zeta \\
\hline${ }^{\circ} \mathrm{C}$ & degree Celsius \\
\hline$A b$ & antibody \\
\hline ABTS & 2,2'-azino-bis(3-ethylbenzothiazoline-6-sulphonic acid) \\
\hline ADAM & a disintegrin and metalloproteinase \\
\hline aGVHD & acute graft-versus-host disease \\
\hline Akt & Akt protein kinase \\
\hline AML & acute myeloid leukemia \\
\hline Amp & ampicillin \\
\hline ANOVA & analysis of variance \\
\hline APC & antigen-presenting cell or allophycocyanine \\
\hline APS & ammonium persulphate \\
\hline BCR & B cell receptor \\
\hline$b p$ & base pair \\
\hline BSA & bovine serum albumin \\
\hline $\mathrm{CaCl}_{2}$ & calcium chloride \\
\hline$C D$ & cluster of differentiation \\
\hline cDNA & complementary DNA \\
\hline cGVHD & chronic graft-versus-host disease \\
\hline CIP & calf intestine phosphatase \\
\hline CMV & cytomegalovirus \\
\hline cpm & counts per minute \\
\hline
\end{tabular}


${ }^{51} \mathrm{Cr}$

CrkL

$\mathrm{Ct}$

CTL

Cy5

D

DAB

DAP10/12

DC

$\mathrm{dH}_{2} \mathrm{O}$

DMEM

DMSO

DNA

dNTP

DPZ

dsDNA

DTT

E. coli

$\mathrm{ECL}$

EDTA

EGTA

ELISA

ERp5

E:T

$\mathrm{EtOH}$

$\mathrm{F}\left(\mathrm{ab}^{\prime}\right)_{2}$

FACS

Fc

FCS

FITC

g

Gapdh

GFP

Grb2

GST

GVHD

$\mathrm{h}$
Chromium-51 isotope

v-Crk avian sarcoma virus CT10-homolog-like protein

cycle threshold

cytotoxic T lymphocyte

cyanine 5

donor

3,3'-diaminobenzidine

DNAX-activating protein of 10 or $12 \mathrm{kDa}$

dendritic cell

destilled water

Dulbecco's modified Eagle's medium

dimethyl sulfoxide

deoxyribonucleic acid

deoxynucleoside triphosphate

German Primate Center

double-stranded DNA

1,4-dithiothreitol

Escherichia coli

enhanced chemiluminescence

ethylenediaminetetraacetic acid

ethylene glycol tetraacetic acid

enzyme-linked immunosorbent assay

endoplasmic reticulum protein 5

effector to target ratio

ethanol

bivalent antigen-binding fragment

fluorescence-activated cell sorting

fragment crystalline

fetal calf serum

fluorescein-5-isothiocyanate

gram

glyceraldehyde 3-phosphate dehydrogenase

green fluorescence protein

Growth factor receptor-bound protein 2

Glutathione-S-transferase

graft-versus-host disease

hour/s 
H60

$\mathrm{HCl}$

HDAC

Hepes

HLA

Hprt

HRP

HSCT

HSP

IFN- $\gamma$

Ig

IL

ITAM

ITIM

i.v.

Jak3

k

Kana

$\mathrm{kb}$

$\mathrm{kDa}$

$\mathrm{KHCO}_{3}$

KIR

I

$\mathrm{LiCl}$

m

M

mAb

MACS

MFI

mg

MGB

$\mathrm{MgCl}_{2}$

mHags

$\mathrm{MHC}$

MICA/B

mlgG

$\min$ histocompatibility protein 60

hydrochloric acid

histone deacetylase

4-(2-hydroxyethyl)-1-piperazineethanesulfonic acid human leukocyte antigen

hypoxanthine-guanine phosphoribosyltransferase

horseradish peroxidase

hematopoietic stem cell transplantation

heat shock protein

interferon-gamma

immunoglobulin

interleukin

immunoreceptor-tyrosine-based activation motif

immunoreceptor-tyrosine-based inhibitory motif

intravenous/ly

Janus kinase 3

kilo

kanamycin

kilo base

kilo Dalton

potassium bicarbonate

killer cell immunoglobulin-like receptor

liter

lithium chloride

milli

molar

monoclonal antibody

magnetic-associated cell sorting

mean fluorescence intensity

milligram

minor groove binder

magnesium chloride

minor histocompatibility antigens

major histocompatibility complex

MHC class I chain-related molecule A/B

mouse immunoglobulin isotype $\mathrm{G}$

minute/s 


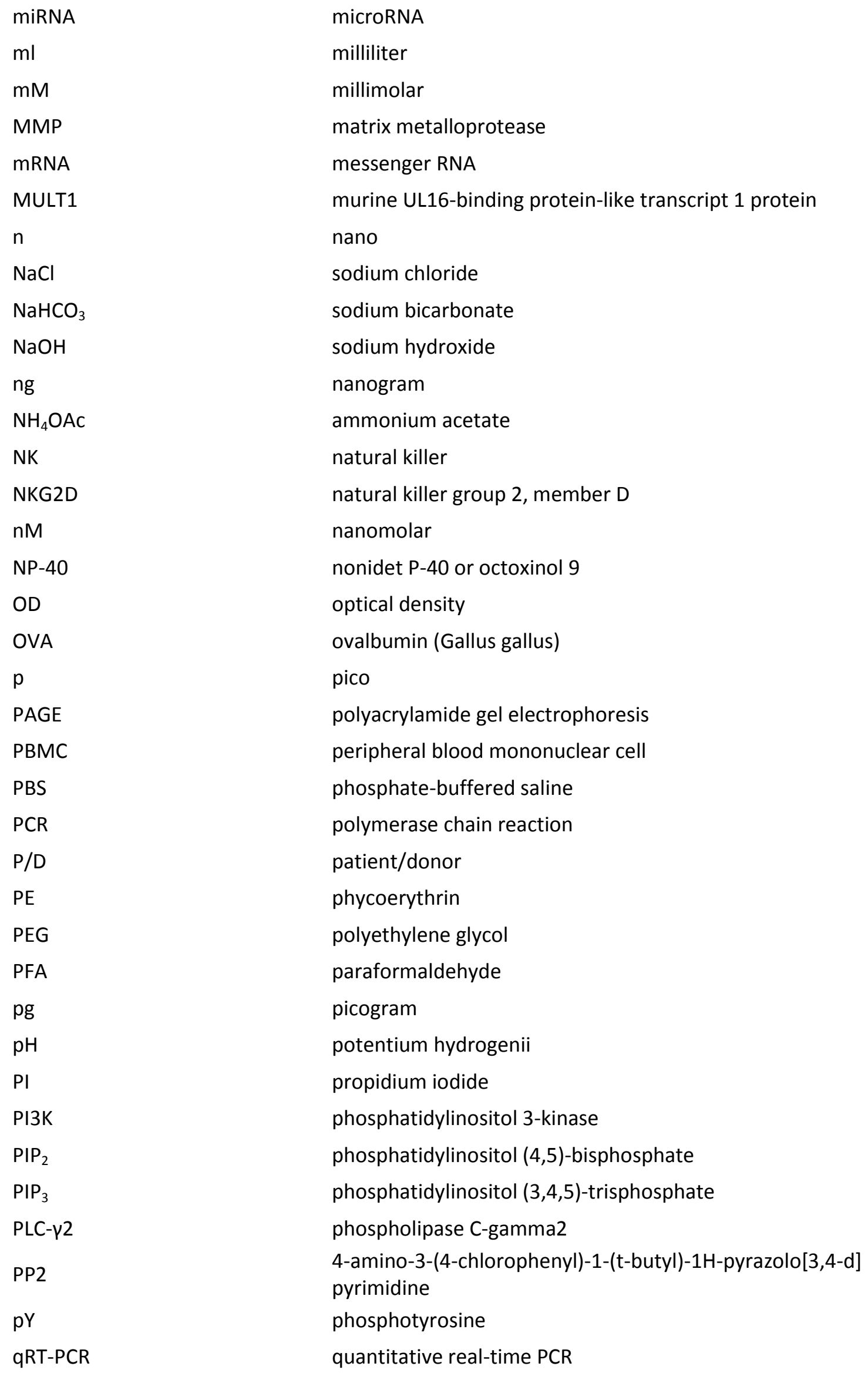


RA

RAE-1

RAET-1

rhIL-2

RNA

RNase

rpm

RT

SAHA

S.C.

SCID

SD

SDS

sec

SEM

$\mathrm{SH} 2$

SLP-76

sMICA

SNP

$\mathrm{SOC}$

Syk

TAE

TBS

TBS-T

TC

TCR

TEMED

TLR

TNF- $\alpha$

Tris

Triton X-100

Tween-20

U

ULBP

UMG

UTR

UV retinoic acid

retinoic acid early inducible-1 protein

retinoic acid early transcript-1 protein

recombinant human interleukin-2

ribonucleic acid

ribonuclease

rounds per minute

room temperature

suberoylanilide hydroxyamic acid

subcutaneous/ly

severe combined immunodeficiency

standard deviation

sodium dodecyl sulfate

second/s

standard error of the mean

src homology 2

$\mathrm{SH} 2$ domain-containing leukocyte protein of $76 \mathrm{kDa}$

soluble MICA

single nucleotide polymorphism

super optimal broth

spleen tyrosine kinase

Tris/acetate/EDTA buffer

Tris-buffered saline

Tris-buffered saline and Tween-20

tri-color

$\mathrm{T}$ cell receptor

$\mathrm{N}, \mathrm{N}, \mathrm{N}^{\prime}, \mathrm{N}^{\prime}$-tetramethylethylene-1,2-diamine

Toll-like receptor

tumor necrosis factor-alpha

Tris(hydroxymethyl)-aminomethan

polyethylene glycol p-(1,1,3,3-tetramethylbutyl)-phenyl ether polyoxyethylene sorbitan monolaurate

unit/s

UL16-binding protein

University Medical Center Göttingen

untranslated region

ultraviolet 
VAV1

$\mathrm{v} / \mathrm{v}$

wt

$w / v$

$x \mathrm{~g}$

Y

ZAP-70

guanine nucleotide exchange factor VAV1 of the Dbl family volume per volume

wild type

weight per volume

accelaration of gravity

year/s

$\zeta$-chain-associated protein of $70 \mathrm{kDa}$ 


\section{Amino acid three-letter and single-letter code}

\begin{tabular}{lcc} 
Amino acid & Three-letter code & Single-letter code \\
\hline \hline Alanine & Ala & A \\
Cysteine & Cys & C \\
Aspartic acid & Asp & D \\
Glutamic acid & Glu & E \\
Phenylalanine & Phe & F \\
Gylcine & Gly & G \\
Histidine & His & H \\
Isoleucine & Ile & I \\
Lysine & Lys & K \\
Leucine & Leu & L \\
Methionine & Met & M \\
Asparaginine & Asn & N \\
Proline & Pro & P \\
Glutamine & Gln & Q \\
Arginine & Arg & R \\
Serine & Ser & S \\
Threonine & Thr & T \\
Valine & Val & V \\
Trypthophane & Trp & W \\
Tyrosine & Tyr & Y
\end{tabular}

\section{Deoxyribonucleotides}

Deoxyribonucleotides

Deoxyadenosine monophosphate

Deoxycytidine monophosphate

Deoxyguanine monophosphate

Deoxythymidine monophosphate
Symbols

A
C
G
T


Introduction

\section{Introduction}

The collection of organs, tissues, cells and molecules, which protects us against pathogens, is called the immune system. The immune system is classically divided into innate (also called natural or native) immunity and adaptive (also known as specific or acquired) immunity. Innate immunity is the first line of defense and mediates the initial protection against pathogens, while adaptive immunity develops more slowly and mediates the later and more specific defense. Immunity is furthermore subdivided into humoral and cellular immunity. Humoral immunity provides defense against extracellular microbes and is mediated primarily by antibodies (Abs; or immunoglobulins) produced by $B$ lymphocytes. The cellular immune system combats intracellular microbes and is mediated mainly by $\mathrm{T}$ lymphocytes. Important features of adaptive immune responses are specificity and memory allowing the adaptive immune system to distinguish among millions of different antigens and to mount larger and more effective responses after repeated exposure to the same antigen. This remarkable specificity is achieved through the clonal expression of an enormous repertoire of $B$ cell receptors (BCRs)/Abs and T cell receptors (TCRs) with distinct specificities resulting from somatic DNA rearrangement. The principal components of the innate immune system are barriers (formed, e.g., by epithelia), phagocytes (monocytes/macrophages and neutrophils), dendritic cells (DCs), natural killer (NK) cells, cytokines and the complement system. Thus, the innate immunity consists of myeloid and lymphoid cells which are able to exert rapid effector responses mediated through a limited repertoire of germline-encoded receptors, such as Toll-like receptors (TLRs) on DCs recognizing pathogen-associated molecular patterns or NK receptors on NK cells. NK cells represent a subset of lymphocytes, which were originally described as part of the innate immune system, however, a recent paradigm shift led to the understanding that they function at the interface between innate and adaptive immunity.

\subsection{Natural killer cells - function and activation}

NK cells were initially defined as large granular lymphocytes with natural cytotoxicity against tumor cells (Oldham and Herberman, 1973; Herberman et al., 1975; Kiessling et al., 1975). Hence, they are often described as first line defense against malignant cells. Later NK cells were recognized as a separate linage of lymphocytes with both cytotoxic and cytokine-producing effector functions (Trinchieri, 1989). Their capacity to distinguish between 'distressed' cells (e.g., tumor, infected or irreparable injured cells affected by physical or chemical exposure) and normal cells is a crucial feature of NK cells. 
NK cells are widespread throughout lymphoid organs (including bone marrow, lymph nodes, tonsils and spleen) and non-lymphoid tissues (e.g., liver, lung and peripheral blood) (Westermann and Pabst, 1992), which is in accordance with their function as innate sentinels. Based on phenotypic, functional and anatomical features distinct subsets of NK cells have been defined. In general, human NK cells can be distinguished into two subsets, which differ in their function and homing properties, on the basis of their surface density expression of the NK cell marker CD56; CD56 ${ }^{\text {dim }}$ and CD56 bright $N K$ cells (Cooper et al., 2001; Farag and Caligiuri, 2006). These two subsets differ in their proliferative potential, cytotoxic activity and capability to secret cytokines, such as interferon-gamma (IFN- $\gamma$ ) and tumor necrosis factor-alpha (TNF- $\alpha$ ), upon stimulation. CD56 ${ }^{\operatorname{dim}}$ NK cells are cytotoxic and express IFN- $\gamma$ upon exposure to tumor cells (Anfossi et al., 2006). The percentage of CD56 ${ }^{\text {dim }} C D 16^{+}$cells in peripheral blood and spleen is around 90\%, while most NK cells in lymph nodes and tonsils are CD56 ${ }^{\text {bright }}$ CD16 showing reduced cytotoxicity, elevated proliferative potential (Ferlazzo and Munz, 2004) and greater levels of immunoregulatory cytokines in response to stimulation with interleukin (IL)-12, IL-15 and IL-18 (Cooper et al., 2001). Thus, NK cells in secondary lymphoid organs are phenotypically and functionally distinct from splenic and circulating NK cells.

NK cells can kill cancer or virus-infected cells controlled by activating and inhibitory receptors. They possess a plethora of cell-surface receptors (Figure 1.1), which enable them to recognize their cellular targets while sparing healthy cells. Whether or not NK cells become activated is determined by engagement of these inhibitory and activating receptors and therefore by the integration of multiple activating and inhibitory signals. In general, negative signals from inhibitory receptors tend to be dominant. Inhibitory receptors recognize self major histocompatibility complex (MHC) class I molecules, which are constitutively expressed by most cells. Under normal conditions, NK cells are tolerant to healthy host cells, since activating signals are dampened by inhibitory receptors (selftolerance). The two major families of MHC class I-specific inhibitory receptors in humans include the killer cell immunoglobulin-like receptors (KIRs) and receptors consisting of CD94 and a NKG2 subunit such as CD94-NKG2A (Figure 1.1). These receptors contain in their intracytoplasmic domain immunoreceptor tyrosine-based inhibitory motifs (ITIMs), which transduce the inhibitory signals (Burshtyn et al., 1996; Olcese et al., 1996; Vivier et al., 2004). Activating NK cell receptors, such as the natural cytotoxicity receptors (NCRs) NKp46, NKp44 and NKp30, recognize cell surface molecules which are commonly expressed on stressed cells. Other alert molecules include infectious non-self ligands (e.g., viral hemagglutinins suggested to be ligands for NKp44 and NKp46) and TLR ligands (Vivier et al., 2008). In contrast to inhibitory receptors, activating receptors possess immunoreceptor tyrosine-based activation motifs (ITAMs) or other stimulatory tyrosine-based motifs in their 
cytoplasmic tails (Moretta et al., 2001) or associate with adaptor molecules carrying these motifs. If inhibitory receptors are not engaged - for instance when virus-infected or tumor cells down-regulate or lose MHC class I expression to evade killing by cytotoxic T lymphocytes (CTLs) - and activating ligands on target cells are additionally expressed, NK cells become activated. This situation known as 'missing-self' triggering of NK cell activation was first described as missing-self hypothesis by Kärre (Kärre, 1985; Kärre et al., 1986; Ljunggren and Kärre, 1990). Furthermore, besides the process of 'infectious non-self recognition' it has been shown that several activating NK cell receptors are able to recognize self cell-surface molecules, which expression can be up-regulated in various stress situations, leading to the concept of 'stress-induced self recognition' (Raulet, 2003; Raulet and Guerra, 2009). Hereby, NK cells can be selectively activated, if the activating signals overcome the inhibitory signals. The stress-induced self was proposed first on the basis of the findings from Bauer et al. (1999) who showed that up-regulation of the stress-inducible MHC class I chain-related molecule A (MICA) switched on in stressed cells, triggers NK cell activation mediated through the activating NK cell receptor NKG2D (NK group 2, member D; also known as CD314).

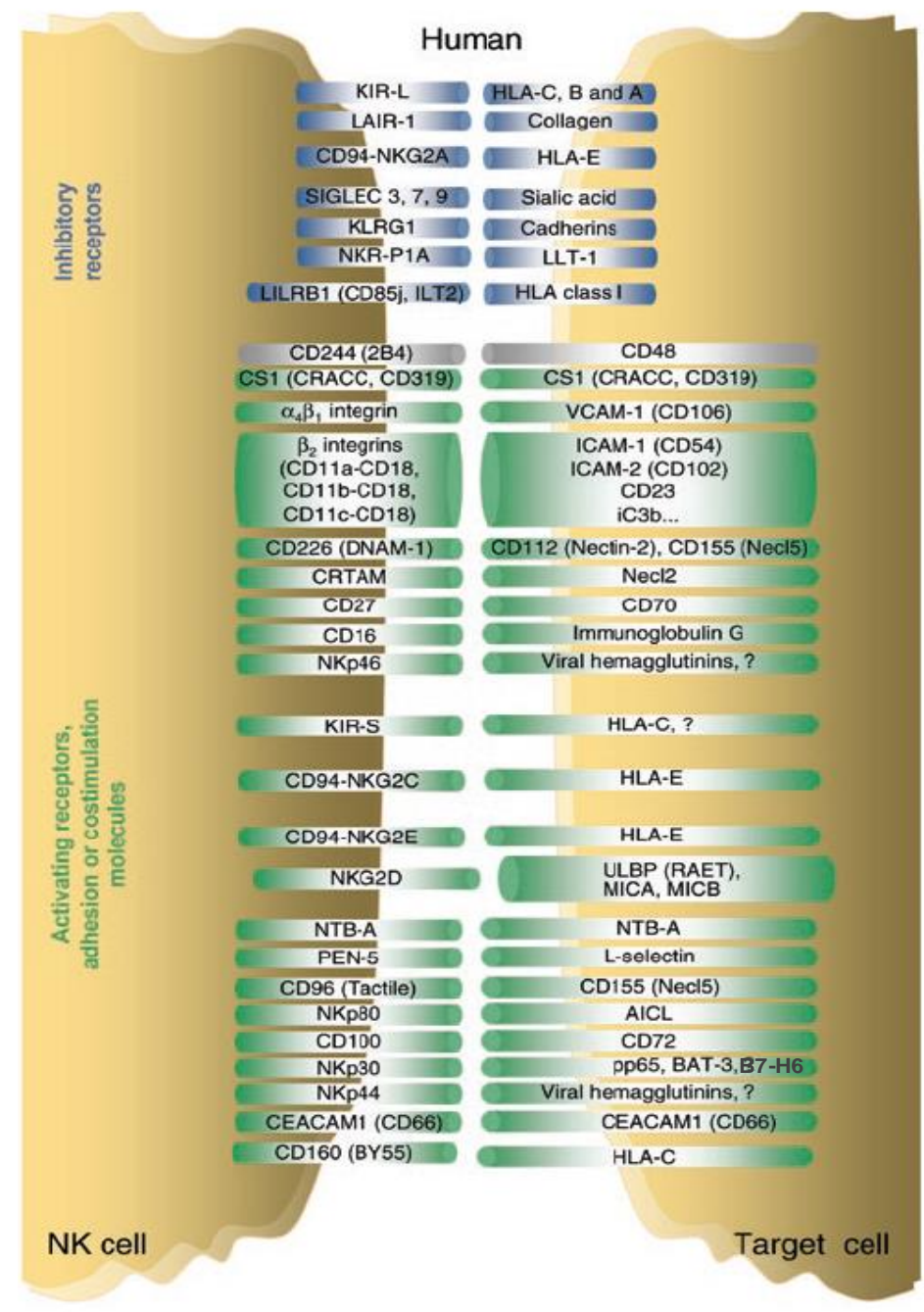

Figure 1.1: Inhibitory receptors, activating receptors and adhesion or co-stimulation molecules of human NK cells.

NK cell activation programs result from the integration of multiple activating and inhibitory signals which vary depending on the nature of the interacting cells. Some human receptor-ligand interactions are depicted. Inhibitory receptors are in blue; 2B4, which can act as an activating or an inhibitory molecule, is in gray; other receptors are in green. $\mathrm{KIR}$, killer immunoglobulin-like receptor; LILR, leukocyte immunoglobulin-like receptor; LAIR, leukocyte-associated immunoglobulinlike receptor; SIGLEC, sialic acid binding immunoglobulin-like lectins; KLRG1, killer cell lectin-like receptor G1; NKR-P1, NK cell receptor protein 1; HLA, human leukocyte antigen; LLT, lectin-like transcript; CRTAM, class I restricted $T$ cell-associated molecule; Necl-2, nectin-like 2; Tactile (also known as CD96), T cell-activated increased late expression; CEACAM1, carcinoembryonic antigen-related cell adhesion molecule 1; NTB-A, NK-T-B antigen; CRACC, CD2-like receptor-activating cytotoxic cell; VCAM-1, vascular cell adhesion molecule-1; ICAM, intracellular adhesion molecule. Adapted from (Vivier et al., 2008). 
Moreover, it has been demonstrated that cross-linking of activating receptors on primary, unstimulated NK cells with agonist Abs does not lead to cytotoxic activity or cytokine secretion when only one receptor alone is cross-linked, except the CD16 receptor, whereas simultaneous crosslinking of different pairs or combinations of activating receptors triggers effector functions (Bryceson et al., 2005; Bryceson et al., 2006). For instance, NKG2D (CD314) and NKp46 (CD335) need the coengagement of other activating NK cell receptors, such as 2B4 (CD244), to activate resting NK cells (Bryceson et al., 2009; Kim et al., 2010; Long et al., 2013). Because of these observations Long suggested the term 'co-activating' receptors. The reason why NK cell activation by CD16 (also known as Fcy receptor IIIA) does not require synergy with other receptors could be that specificity is determined by Ab-producing B cells (Long et al., 2013). The Fc receptor CD16 enables NK cells to detect Ab-coated target cells and to exert antibody-dependent cellular cytotoxicity (ADCC) (Titus et al., 1987). The requirement for a synergistic combination of activation receptors may therefore serve to prevent unrestrained activation of resting NK cells suggesting that a critical threshold of activating signals must be reached by these co-activating receptors to overcome inhibition signals from inhibitory receptors in order to mount an effective response (Lanier, 2008; Long et al., 2013).

NK cells were initially described as lymphocytes, which exert direct cellular cytotoxicity against malignant or infected cells without prior activation or 'priming'. However, numerous studies in the last years have led to a more nuanced view of NK cells showing that the cytokine and chemokine environment as well as interactions with other cells, such as DCs, macrophages and T cells, play an important role for the regulation of NK cell cytotoxic and cytokine responses (Figure 1.2) (Long, 2007; Long et al., 2013). Of major importance is the cross-talk between NK cells and DCs which coordinates their responses by communicating through direct cell-to-cell contact and soluble factors (DegliEsposti and Smyth, 2005; Long et al., 2013). Potent activators of NK cell effector function include type I IFNs, such as IFN- $\alpha$ and IFN- $\beta$, and cytokines, including IL-12, IL-18 and IL-15 (Walzer et al., 2005). The cytokine IL-12, produced by mononuclear phagocytes and DCs, promotes secretion of the macrophage-activating cytokine IFN- $\gamma$ by NK cells and enhances NK cell-mediated cytotoxic activity. Macrophages produce IL-18 which synergizes with IL-12 in stimulating the production of IFN- $\gamma$ by NK cells. IL-2, produced by antigen-activated T cells, furthermore promotes proliferation, differentiation, cytotoxicity and, to some extent, also cytokine secretion of NK cells (Trinchieri, 1989). Structurally similar to IL-2 is IL-15, which is produced by mononuclear phagocytes among other cells and stimulates the proliferation of NK cells. DCs prime NK cells by trans-presenting IL-15 (Figure 1.2) (Lucas et al., 2007). 


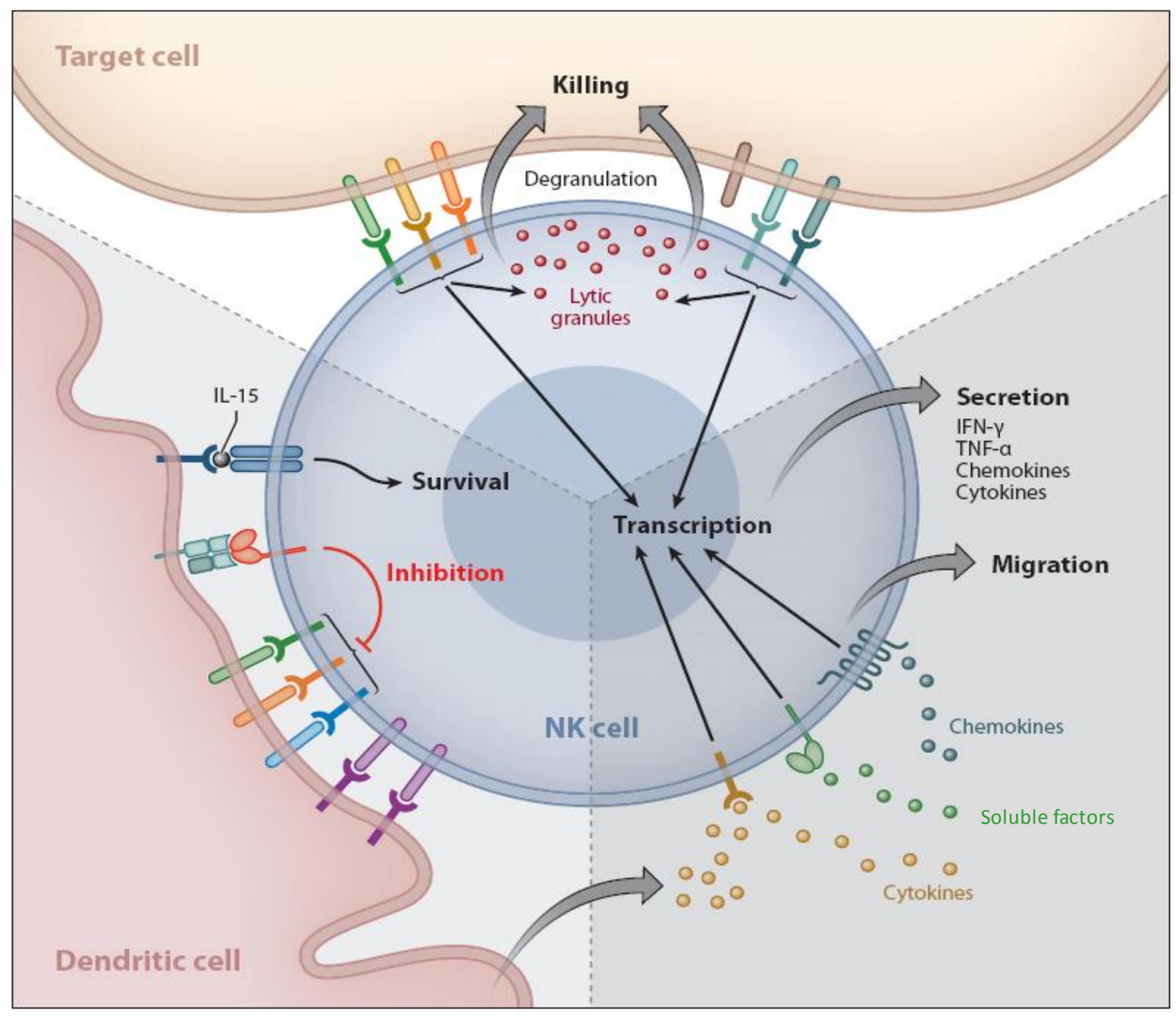

Figure 1.2: Multiple signals control NK cell responses.

An array of NK cell activation receptors bind to ligands on other cells. Target cell killing requires NK cell activation. Since NK cells do not have a single activation receptor, except CD16, but require for activation synergistic signals from combinations of receptors which are integrated, Long suggested the term 'co-activating receptor'. Inhibitory receptors (red) for $\mathrm{MHC}$ class I molecules exert dominant inhibition of cytotoxicity and secretory response, as seen in the NK cell-dendritic cell (DC) interaction. DCs also receive signals from ligands on NK cells (purple). In the absence of inhibition through MHC class I molecules, target cells which express ligands for activation receptors are killed. NK cells respond to various soluble activators, such as cytokines and chemokines, which deliver signals for functions as migration and survival. The pro-survival cytokine IL-15 bound to the IL-15 receptor (R) $\alpha$ chain is trans-presented by other cells such as DCs to the IL-15R $\beta \gamma_{c}$ chains on NK cells. In response to soluble factors, NK cells secrete IFN- $\gamma$, TNF- $\alpha$, other cytokines and chemokines. Adapted from (Long et al., 2013).

\subsubsection{NK cells in tumor immunosurveillance}

After observations in the 1970s that NK cells can kill tumor cells (Oldham and Herberman, 1973; Herberman et al., 1975; Kiessling et al., 1975), the antitumor effect of NK cells has been documented in many models and instances. In vitro, mouse and human NK cells are able to kill a broad range of 
tumor cells of hematopoietic and non-hematopoietic origin (Vivier et al., 2012). In vivo, mouse NK cells have been shown to eliminate many transplantable and spontaneous tumors (Smyth et al., 2002; Vesely et al., 2011). Antitumor NK cell activity requires up-regulation of ligands for NK activation receptors and/or loss of MHC class I molecules on tumor cells. For instance, mouse models with selective deletion of activating NK cell receptors, such as NKG2D, have demonstrated an important contribution of NK cells to tumor immunosurveillance (Gilfillan et al., 2008; Guerra et al., 2008). Additionally, NK cell-depleted mice are more susceptible to methylcholanthrene-induced sarcomas. In this model, NK cells seem to use in part the NKG2D pathway to protect the host from tumor development (Smyth et al., 2005). In humans, selective NK cell deficiencies are extremely rare (Orange and Ballas, 2006). However, an epidemiological 11-year follow-up study of a general population has linked low peripheral blood NK cell activity with an increased incidence of cancer (Imai et al., 2000). Furthermore, several studies found an association between NK cell infiltration into tumor tissue and better disease prognosis in non-small cell lung carcinomas (Carrega et al., 2008; Platonova et al., 2011), renal cell carcinoma (Eckl et al., 2011) and colorectal cancer (Halama et al., 2011). Altogether, these findings show that NK cells participate in tumor immunosurveillance in mice and humans.

\subsubsection{Effector functions of NK cells}

Cytotoxicity and cytokine production are effector functions of NK cells. NK cell activation leads to elimination of distressed cells directly through NK cell cytotoxicity or indirectly through the production of pro-inflammatory cytokines such as IFN- $\gamma$ and TNF- $\alpha$.

In general, two major mechanisms of NK cell cytotoxicity exist; perforin/granzyme-mediated and death receptor-mediated apoptosis (Screpanti et al., 2005). Perforin/granzyme-mediated killing involves the delivery of the content of specialized secretory lysosomes, known as lytic granules, into the immunological synapse between the NK cell and its target cell (Shresta et al., 1998; Griffiths, 2003). Two types of cytotoxic proteins, which are contained in lytic granules, are proteolytic granzymes, such as granzyme B (Heusel et al., 1994), and the pore-forming protein perforin (Catalfamo and Henkart, 2003; Voskoboinik et al., 2006). Granzymes are serine proteases, which cleave and thereby activate a family of death-inducing intracellular proteases, called caspases, in target cells. Granzymes can enter the cytoplasm of the targets via perforin-dependent mechanisms (Cullen and Martin, 2008). In death receptor-mediated apoptosis, death ligands on NK cells, such as the membrane protein Fas ligand (FasL; also known as CD178) or TNF-related apoptosis-inducing 
ligand (TRAIL), can bind to death-inducing receptors expressed on the surface of target cells (Screpanti et al., 2001). Upon ligation of death receptors with their ligands, intracellular adapter molecules are recruited, which in turn can associate with initiator caspases through death effector domains or caspase recruitment domain interactions (Nicholson, 1999). The subsequent activation of the initiator caspases starts then the caspase cascade which finally results in demise of the target cells (Ashkenazi and Dixit, 1998). Thus, the death receptor-mediated induction of cell death does not require granule release. However, this death receptor-mediated pathway may play a minor role in NK cell cytotoxicity compared to the perforin/granzyme-mediated apoptosis which is the principal pathway used by NK cells to eliminate virus-infected and transformed cells (Screpanti et al., 2005).

Besides exerting direct cytotoxicity, NK cells are furthermore major producers of immunostimulatory and pro-inflammatory cytokines and chemokines leading indirectly to target cell elimination (Trinchieri, 1989). As an example, the pro-inflammatory cytokine IFN- $\gamma$ potentiates functions of antigen-presenting cells (APCs; monocytes, macrophages, DCs and B cells) including antimicrobial activity, phagocytosis, oxidative burst capability and production of nitrous oxide (Trinchieri and Gerosa, 1996). NK cells also produce various other cytokines, both pro-inflammatory and immunosuppressive, such as TNF- $\alpha$ and IL-10, respectively, and growth factors such as granulocyte macrophage-colony-stimulating factor (GM-CSF) as well as chemokines. Secretion of cytokines and chemokines by NK cells participates in the shaping of adaptive immune responses (Vivier et al., 2011)

\subsubsection{Activating NK cell receptor NKG2D}

One of the best-characterized activating NK cell receptors is NKG2D (NK group 2, member D). This receptor serves as a major 'stress-induced self' recognition receptor, which binds to up-regulated self-protein ligands on stressed cells, resulting in the elimination of infected cells and tumor cells (Raulet, 2003; Raulet et al., 2013).

In humans, the NKG2D gene is encoded in the natural killer gene complex (NKC) on chromosome 12 next to the other NKG2 genes (NKG2A, NKG2C, NKG2E and NKG2F) and the CD94 gene (Brown et al., 1997). The NKG2D receptor as well as the NKG2A, NKG2C and NKG2E receptor are lectin-like, type 2 transmembrane receptors (Houchins et al., 1991) but despite their names, the other NKG2 proteins are dissimilar to NKG2D in sequence, specificity and function (Raulet, 2003). NKG2D exists as homodimer and recognizes a diversity of self cell-surface molecules (see section 1.1.4) which are upregulated in pathological situations. NKG2A, NKG2C and NKG2E, in contrast, possess highly related 
sequences, are present as heterodimers with CD94 and recognize the non-classical MHC class I molecule human leukocyte antigen E (HLA-E) (Braud et al., 1999).

The NKG2D receptor is present on several lymphoid and myeloid cell types. In humans, NKG2D is expressed by NK cells, CD8 ${ }^{+} \alpha \beta$ T cells and subsets of $\gamma \delta$ T cells, such as peripheral blood (Bauer et al., 1999) and intestinal intraepithelial $\gamma \delta$ T cells (Roberts et al., 2001), and NKT cells (Raulet, 2003; Champsaur and Lanier, 2010; Raulet et al., 2013). Furthermore, also some $\mathrm{CD}^{+} \alpha \beta$ T cells express NKG2D (Jamieson et al., 2002; Groh et al., 2006), e.g., a fraction of $\mathrm{CD}^{+}{ }^{+} \mathrm{T}$ cells from patients with rheumatoid arthritis (Groh et al., 2003). In mice, the NKG2D receptor is also expressed on NK cells, certain $\mathrm{T}$ cell subsets and in contrast to humans also on macrophages after activation with lipopolysaccharide and different cytokines (Diefenbach et al., 2000; Jamieson et al., 2002). In activated $C D 8^{+} \alpha \beta$ T cells (Groh et al., 2001) and subsets of $\gamma \delta$ T cells (Girardi et al., 2001; Whang et al., 2009), NKG2D functions as a co-stimulatory molecule, whereas NKG2D signaling on NK cells triggers cytotoxicity (Billadeau et al., 2003) and cytokine secretion (Andre et al., 2004). However, it has been also reported that after activation of $C D 8^{+} \mathrm{T}$ cells, NKG2D engagement in the absence of TCR activation was sufficient to elicit killing of target cells (Meresse et al., 2004). $\gamma \delta T$ cells may also be directly activated by NKG2D in the absence of TCR engagement (Rincon-Orozco et al., 2005; Nitahara et al., 2006). Taken together, NKG2D-mediated pathways are important for detection and elimination of malignant cells (Guerra et al., 2008) and are critical in defense against several pathogens (Fang et al., 2008; Wesselkamper et al., 2008; Champsaur and Lanier, 2010; Choy and Phipps, 2010). Thus, the immunoreceptor NKG2D plays an important role in immunosurveillance of malignancies and infections.

\subsubsection{NKG2D-mediated signaling}

Many immunoreceptors are multi-subunit complexes consisting of ligand-binding recognition subunits, which are non-covalently associated with signal-transducing subunits, or so-called 'adaptors'.

The human NKG2D receptor complex is a hexamer, with one NKG2D homodimer associating with two homodimeric DAP10 (DNAX-activating protein of $10 \mathrm{kDa}$ ) adaptor molecules (Garrity et al., 2005) as depicted in Figure 1.3. The cytoplasmic domain of each DAP10 monomer contains one tyrosine-based signaling motif (YxxM; where $x$ designates any amino acid) (Wu et al., 1999; Lanier, 2009). Receptor engagement induces tyrosine phosphorylation of the signaling motifs by activated Src family kinases as revealed by inhibition studies showing that signaling induced by anti-NKG2D Abs through the 
NKG2D-DAP10 complex was prevented by the specific Src family kinase inhibitor PP2 (Billadeau et al., 2003). Phosphorylated DAP10 is able to bind either the p85 subunit of phosphatidylinositol 3-kinase (PI3K) (Wu et al., 1999; Sutherland et al., 2002) and subsequently the adaptor molecule CrkL (v-Crk avian sarcoma virus CT10-homolog-like) (Segovis et al., 2009) or the adaptor Grb2 (growth factor receptor-bound protein 2 ) in association with the guanine nucleotide exchange factor VAV1 and SOS1 (son of sevenless 1) forming a Grb2 - VAV1 - SOS1 signaling complex (Gilfillan et al., 2002; Graham et al., 2006; Upshaw et al., 2006; Lanier, 2008). Mutagenesis and inhibition studies showed that NKG2D-mediated signaling requires both a DAP10-bound Grb2-VAV1 intermediate and the p85 subunit of PI3K (Billadeau et al., 2003; Upshaw et al., 2006). Both pathways partly trigger similar downstream consequences.

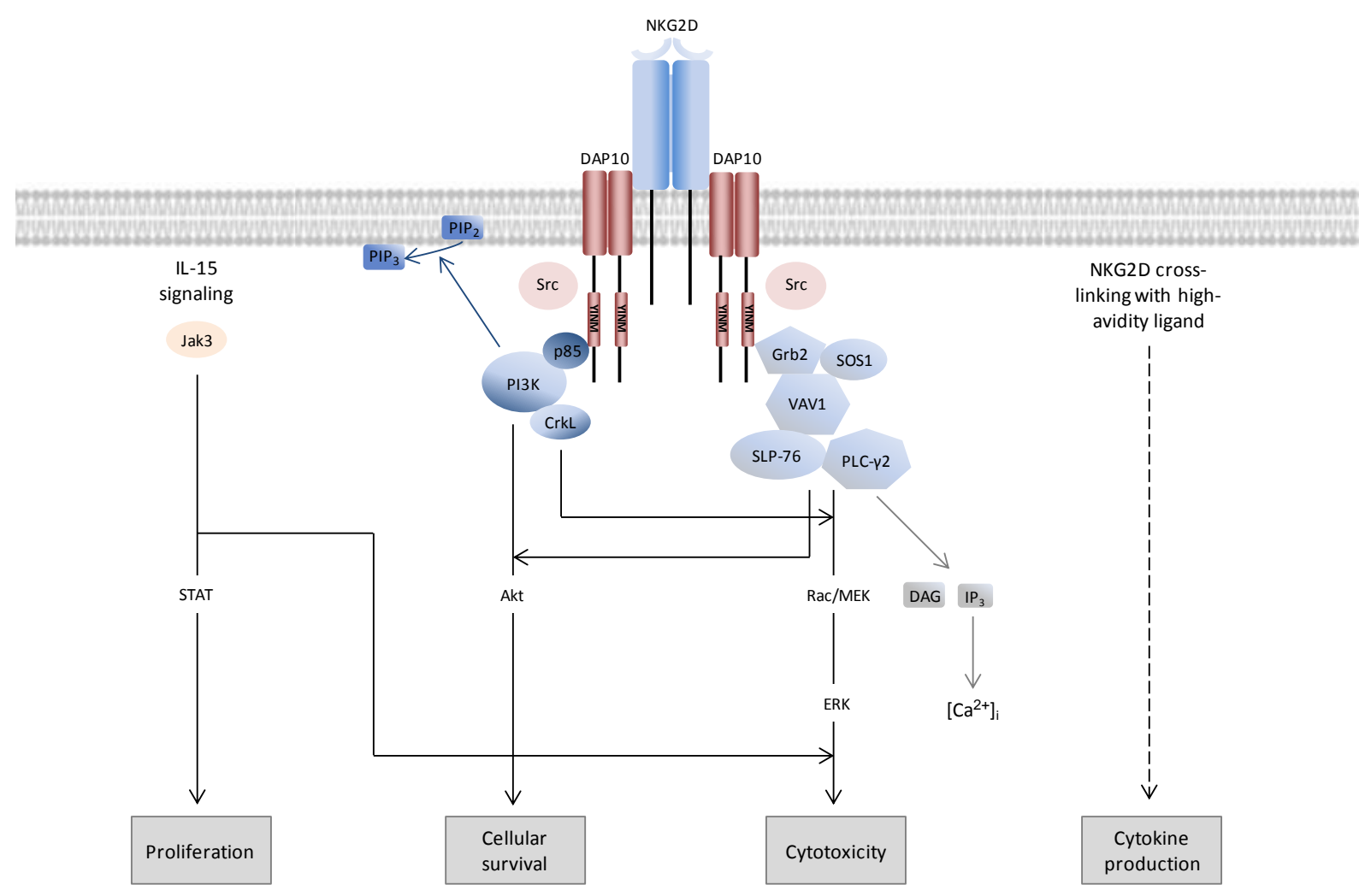

Figure 1.3: DAP10-mediated NKG2D signaling in human NK cells.

Cross-linking of the NKG2D receptor with its ligands induces tyrosine phosphorylation of the YINM motif in the cytoplasmic domain of DAP10 by auto-phosphorylated Src family kinases leading to the activation of underlying signaling pathways. Phosphorylated DAP10 is able to bind either the $\mathrm{p} 85$ subunit of PI3K and subsequently the adaptor CrkL or the adaptor Grb2 in association with VAV1 and SOS1 forming a Grb2 - VAV1 - SOS1 signaling complex. These events trigger distal signaling cascades as depicted. Akt, anti-apoptotic serine-threonine kinase; CrkL, v-Crk avian sarcoma virus CT10-homolog-like protein; DAG, diacylglycerol; ERK, mitogen-activated protein (MAP) kinase; DAP10, DNAX-activating protein of $10 \mathrm{kDa}$; Grb2, growth factor receptor-bound protein 2; $\mathrm{IP}_{3}$, inositol $(3,4,5)$-trisphosphate; Jak3, Janus kinase 3; MEK, MAP kinase; PI3K, phosphatidylinositol 3-kinase; $\mathrm{PIP}_{2}$, phosphatidylinositol (3,4)-bisphosphate; $\mathrm{PIP}_{3}$, phosphatidylinositol (3,4,5)-trisphosphate; PLC-y2, phospholipase C- $\gamma 2$; Rac, GTPase; SLP-76, Src homology 2 (SH2) domain-containing leukocyte protein of $76 \mathrm{kDa}$; SOS1, son of sevenless 1; Src, Src family kinases; STAT, signal transducers and activators of transcription; VAV1, guanine nucleotide exchange factor. 
Binding of Grb2 to DAP10 induces phosphorylation of the downstream molecules VAV1, Src homology 2 (SH2) domain-containing leukocyte protein of 76 kDa (SLP-76) and phospholipase C- $\gamma 2$ (PLC-y2) (Billadeau et al., 2003; Upshaw et al., 2006) which leads to $\mathrm{Ca}^{2+}$ influx and recruitment and activation of several cytoplasmic enzymes such as the MAP kinases MEK and ERK. This triggers NK cell activation, which leads to actin cytoskeleton reorganization and cell polarization and finally results in granule release and cytotoxicity (Lanier, 2008). PI3K activation by binding of p85 to DAP10 induces production of phosphatidylinositol $(3,4,5)$-trisphosphate $\left(\mathrm{PIP}_{3}\right)$, which is required to form the NKG2D immunological synapse (Giurisato et al., 2007). PI3K additionally activates an anti-apoptotic serinethreonine kinase called Akt, which promotes NK cell survival (Wu et al., 1999; Sutherland et al., 2002). Moreover, it has been proposed that the intracellular signaling components of the IL-15 receptor (IL-15R) and NKG2D-DAP10 are coupled. The Janus kinase 3 (Jak3), recruited and activated by the cytokine IL-15, could contribute to DAP10 phosphorylation and initiated killing of target cells (Horng et al., 2007). This is in accordance with observations showing the necessity for human NK cells to be 'primed' by cytokine stimulation, such as IL-15 or IL-2, before certain NK cell receptors, including NKG2D, are competent to elicit cytotoxicity (Bryceson et al., 2005; Bryceson et al., 2006).

The influence of NKG2D-DAP10 receptor complexes on cytokine production is less well understood. However, NKG2D-DAP10 complexes can induce cytokine production, such as IFN- $\gamma$ and GM-CSF, if cross-linked with a high-avidity ligand, in vitro. Interestingly, cytokine secretion, in contrast to cytotoxicity, was observed only after NKG2D cross-linking by soluble recombinant NKG2D ligands, including MICA and ULBP1/2, (Kubin et al., 2001; Andre et al., 2004) but not by anti-NKG2D Abs (Billadeau et al., 2003). However, this difference has been questioned, since cytokines can be induced by cross-linking NKG2D with anti-NKG2D mAb, if plates are coated with a sufficiently high concentration of the agonist Ab (Lanier, 2008). Thus, it seems that the NKG2D/DAP10 receptor complex cannot only induce cytotoxicity but also production of cytokines (Lanier, 2009).

\subsubsection{Ligands of NKG2D}

Notably, a diversity of NKG2D ligands exists, which are not or only expressed at low levels under normal conditions, but can be up-regulated as a result of cellular stress, infection or malignant transformation (Raulet, 2003). Several NKG2D ligands have been identified in humans and mice. These ligands are self proteins, encoded in the host's genome, and are related to MHC class I molecules (Champsaur and Lanier, 2010; Raulet et al., 2013). 
The MHC class I chain-related protein A (MICA) was the first ligand identified for human NKG2D followed by its close relative MICB (Bauer et al., 1999). No orthologs of MICA/B have been identified in the mouse and rat genome. Further NKG2D ligands in humans include up to six different UL16binding proteins (ULBPs; ULBP1-6), also known as retinoic acid early transcript-1 (RAET-1) proteins (Cosman et al., 2001; Onda et al., 2001; Steinle et al., 2001; Radosavljevic et al., 2002). In contrast to MICA/B, there is a family of mouse genes orthologous to the human ULBP/RAET-1 family. These mouse proteins include five different isoforms of retinoic acid early inducible-1 (RAE-1) proteins, one murine UL16-binding protein-like transcript 1 (MULT1) protein and three different isoforms of histocompatibility 60 (H60) proteins (Raulet, 2003; Raulet et al., 2013). The different ligands of NKG2D are markedly distinct in sequence, show a wide range of binding affinities to NKG2D and some of them are transmembrane proteins, while others are glycosylphosphatidylinositol (GPI)linked (Diefenbach et al., 2000; Raulet, 2003; Strong and McFarland, 2004; Champsaur and Lanier, 2010). However, as shown by X-ray diffraction analysis the topography of binding of the different NKG2D ligands appears to be similar (Radaev and Sun, 2003; Strong and McFarland, 2004).

\subsubsection{Regulation of NKG2D ligand expression}

Cell surface expression of the diverse ligands of the activating NK cell receptor NKG2D must be tightly regulated to avoid destruction of healthy cells by NK cells. Therefore, cell and tissue-specific events control both transcriptional and posttranscriptional regulatory processes.

Some NKG2D ligand transcripts, e.g., mouse RAE-1, are rarely expressed in normal cells but their expression is detectable in tumor and infected cells, while transcripts of other ligands, including human MICA/B, ULBPs and mouse MULT1, are found in healthy and diseased tissues (Cosman et al., 2001; Radosavljevic et al., 2002; Cerwenka, 2009). MICA and MICB are inducible by heat shock in certain cell lines (Groh et al., 1996). The promoters of the MIC genes contain heat shock elements similar to those found in heat shock protein 70 (HSP70) genes, which bind to heat shock factor-1, as well as a binding site for the transcription factor activator protein 1 (AP-1) (Venkataraman et al., 2007). MICA and MICB proteins have also been shown to be up-regulated in tumor cells upon retinoic acid (RA) treatment (Jinushi et al., 2003) - similarly as RAE-1 molecules (Nomura et al., 1996). Furthermore, NKG2D ligand expression is induced by DNA-damaging agents, such as ionizing radiation, 5-fluorouracil, aphidicolin, cisplatin and UV-C (Gasser et al., 2005). Oncogenes, such as adenovirus serotype 5 E1A, also up-regulate NKG2D ligand expression (Routes et al., 2005). 
Moreover, expression of NKG2D ligands is regulated by posttranscriptional mechanisms, which include inhibition of ligand expression by microRNAs (miRNAs). Viral-encoded as well as endogenous cellular miRNAs can control expression of ligands, including MICA, MICB and ULBP3, by binding to 3' untranslated region ( $3^{\prime}$-UTR) sites of the corresponding messenger RNA (mRNA) of the target genes (Stern-Ginossar et al., 2008; Raulet et al., 2013).

Posttranslational regulation includes cleavage from the cell surface (see section 1.1.5), excretion in vesicles such as exosomes and secretion from the cell (Raulet et al., 2013). A further mechanism of posttranslational regulation of MULT1 is ubiquitin-dependent lysosomal degradation of this ligand in healthy cells, which is decreased in response to UV stress or heat shock in stressed cells (Nice et al., 2009). It is conceivable that cell surface expression of other NKG2D ligands, including MICA, is also regulated by ubiquitination (Thomas et al., 2008; Cerwenka, 2009).

\subsubsection{Tumor immune evasion - NKG2D down-regulation and MICA shedding}

In general, tumors have evolved diverse immune evasion strategies to safeguard their survival, which often involve blinding or inhibiting immune responses. Tumor-mediated counter-regulation mechanisms to escape NK cell surveillance include NKG2D down-regulation after chronic exposure of NK cells to NKG2D ligands on tumor cells leading to impaired NK cell cytotoxic function and tumor cell-mediated shedding of NKG2D ligands resulting in the presence of immunosuppressive soluble particles of the corresponding ligands (Figure 1.4).

Several studies have shown that persistent expression of NKG2D ligands, such as MICA, and sustained triggering of receptor signaling by these ligands can lead to profound down-modulation of the cell surface expression of NKG2D and consequent compromised NK cell-mediated cytotoxicity upon subsequent receptor engagement (Groh et al., 2002; Coudert et al., 2005; Oppenheim et al., 2005; Wiemann et al., 2005). Rapid endocytosis and partial lysosomal degradation of both components of the NKG2D/DAP10 receptor complex may explain the loss of NKG2D membrane expression and the impairment in NK cell cytotoxic capacity after chronic exposure to NKG2D ligands (Roda-Navarro and Reyburn, 2009). Furthermore, TGF- $\beta$ (Castriconi et al., 2003; Lee et al., 2004), IL21 (Burgess et al., 2006) and macrophage migration inhibitory factor which is also produced by tumor cells (Krockenberger et al., 2008) are negative regulators of NKG2D and down-modulate the receptor expression thereby suppressing NK cell cytotoxic activity. 
a

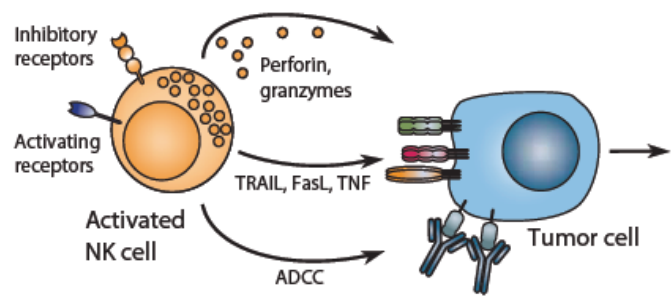

b
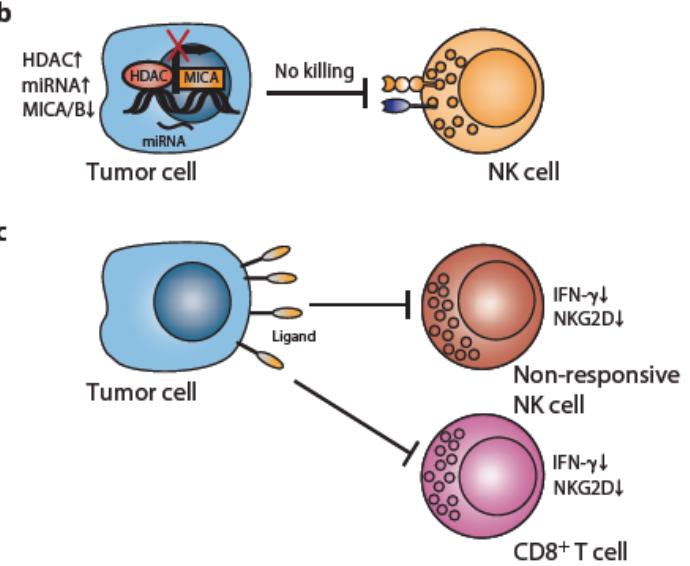

d
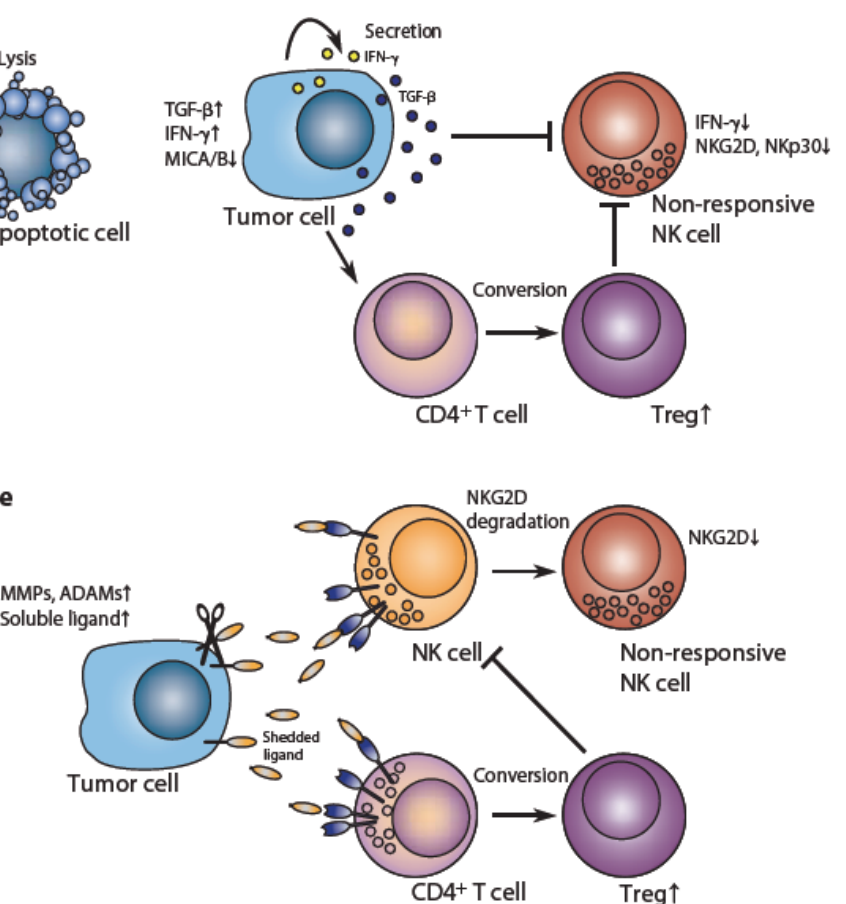

Figure 1.4: Strategies of tumor immune escape from NK cell-mediated immunosurveillance.

(A) NK cells kill their targets by the combined release of cytotoxic granules, the expression or release of TRAIL, FasL and TNF and ADCC resulting in apoptosis of the target cell. Tumor cells may escape NK cell-dependent immunosurveillance by several pathways: (B) alterations in DNA modifying enzymes such as histone deacetylases (HDACs) or miRNAs, involved in epigenetic gene regulation, repress the expression of MICA/B, (C) persistent expression of activating ligands and sustained triggering of NKG2D leads to hypo-responsiveness and decreased cytotoxicity due to decreased NKG2D expression and reduced IFN- $\gamma$ production, (D) tumor-released cytokines, such as TGF- $\beta$ and IFN- $\gamma$, repress MICA/B expression, down-regulate NKG2D expression and IFN- $\gamma$ production in NK cells and promote the conversion of $\mathrm{CD} 4^{+} \mathrm{T}$ cells into regulatory $\mathrm{CD} 4^{+} \mathrm{CD} 25^{+} \mathrm{FOXP} 3^{+} \mathrm{T}\left(\mathrm{T}_{\text {reg }}\right)$ cells, suppressing immunosurveillance, (E) and up-regulation of MMPs and ADAMs, which promote the shedding of activating ligands such as MICA, which binds to NKG2D on CD4 ${ }^{+} \mathrm{T}$ cells and NK cells resulting in hypo-responsiveness in NK cells due to degradation of NKG2D and CD4 ${ }^{+} \mathrm{T}$ cell conversion into $\mathrm{T}_{\text {reg }}$ cells. (Adapted from Groth et al., 2011).

NKG2D is also down-regulated by circulating tumor-derived soluble NKG2D ligands. Members of the family of matrix metalloproteases (MMPs) and the 'a disintegrin and metalloproteinase' (ADAM) family, including ADAM10 and ADAM17, cleave MICA (Salih et al., 2002; Kaiser et al., 2007; Waldhauer et al., 2008). The $\alpha 3$ domain of MICA forms a complex with the disulphide isomerase/chaperon endoplasmic reticulum protein 5 (ERp5) on the surface of tumor cells which induces a conformational change enabling the proteolytic cleavage of MICA. The soluble MICA (sMICA) then interacts with NKG2D, which in turn induces the internalization and degradation of the NKG2D/DAP10 receptor complex and stimulates the expansion of immunosuppressive $\mathrm{NKG}_{2} \mathrm{D}^{+} \mathrm{CD} 4^{+} \mathrm{T}$ cells (Groh et al., 2002; Doubrovina et al., 2003; Groh et al., 2006; Choy and Phipps, 2010). This 
phenomenon is called 'MICA shedding' (Groh et al., 2002; Kaiser et al., 2007). Shedding of NKG2D ligands has been reported for most cancers and some hematopoietic malignancies, in which not only soluble ligands but also tumor-derived exosomes (Clayton et al., 2008) may contribute to NKG2D down-modulation. A number of clinical trials showed an association between tumor-associated or soluble NKG2D ligands and disease progression and poor prognosis in different malignant diseases (El-Gazzar et al., 2013) (see section 1.2.3).

Taken together, these tumor-mediated counter-regulation mechanisms lead to tumor evasion from NK cell-mediated immunity. Thus, future studies should improve NK cell immunotherapy by developing strategies to overcome tumor immune evasion mechanisms (Groth et al., 2011).

\subsection{Highly polymorphic NKG2D ligand MICA}

MIC genes, initially also called Perth beta block transcript 11 (PERB11), were first described in 1994 by two independent groups (Bahram et al., 1994; Leelayuwat et al., 1994). The MIC genes are highly conserved and are present in most mammals, except in rodents (Kumanovics et al., 2003). The human MIC family encompasses seven MIC genes, named MICA to MICG, which are encoded in the class I region of the human MHC gene complex on chromosome 6. Only the MICA gene and its homologue $M I C B$ are functional, whereas the other family members are pseudogenes. An important feature of MICA and MICB is their high degree of polymorphism. The MICA gene is located head-tohead and approximately $46 \mathrm{~kb}$ or $70 \mathrm{~kb}$ centromeric to the HLA-B or MICB gene, respectively (Shiina et al., 1999; Bahram, 2000). MICA possesses six exons separated by five introns (Figure 1.5).

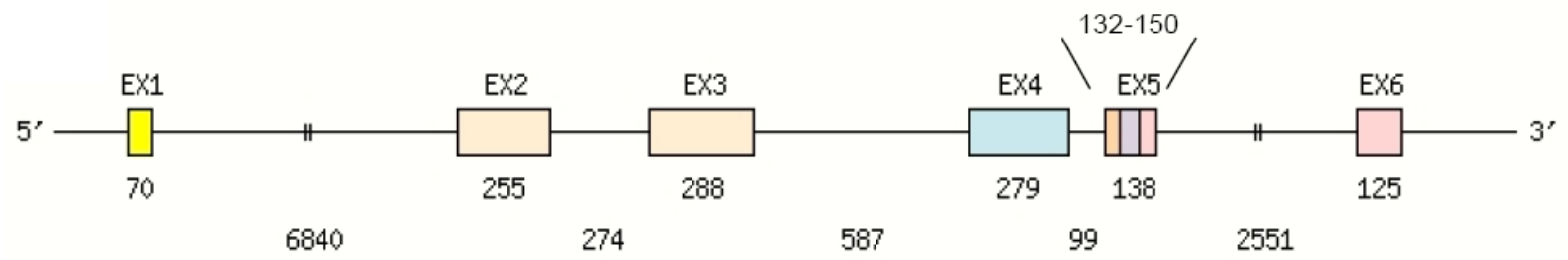

Figure 1.5: Exon/intron organization of the human MICA gene.

The MICA gene has six exons separated by five introns. Exon (EX) and intron lengths are given in base pairs (bp) (EMBL/GenBank/DDBJ accession number, MICA*04 (A6) X92841). Introns indicated with II are not at scale. EX1 encodes the leader-peptide region, EX2 the G- $\alpha 1$-like domain, EX3 the G- $\alpha 2$-like domain, EX4 the C-like domain, EX5 a connecting, a transmembrane and a part of an intracytoplasmic region and EX6 the main part of the intracytoplasmic region. The length of the EX5 (132 to $150 \mathrm{bp})$ depends on a triplet repeat microsatellite polymorphism $(\mathrm{GCT})_{\mathrm{n}}$ in the transmembrane region. A length of $138 \mathrm{bp}$ for EX5 corresponds to an A6 allele. Colors are according to IMGT color menu for regions and domains (http://imgt.cines.fr). Adapted from (Frigoul and LeFranc, 2005). 
MICA is constitutively expressed only on a few cell types such as gastrointestinal epithelium, perhaps as a consequence of stimulation by the neighboring bacterial flora, (Groh et al., 1996). However, MICA expression is induced by cellular and genotoxic stress (Groh et al., 1996; Gasser et al., 2005) leading to an up-regulation of the expression on malignant cells, such as on a variety of solid tumors of epithelial origin as well as in lymphoproliferative malignancies, or virus-infected cells (Raulet, 2003; Champsaur and Lanier, 2010; Raulet et al., 2013).

\subsubsection{MICA structure and MICA-NKG2D interaction}

MICA is a type-1 transmembrane protein of $43 \mathrm{kDa}$ (Bahram et al., 1994; Raulet, 2003). Its domain structure is similar to those of classical MHC class I molecules and comprises three extracellular domains, called $\alpha 1$ (encoded by exon 2), $\alpha 2$ (encoded by exon 3 ) and $\alpha 3$ (encoded by exon 4 ), a transmembrane segment, including a connecting region and a part of the cytoplasmic region, (encoded by exon 5) and a carboxy-terminal cytoplasmic tail (encoded by exon 6) (see above, Figure 1.5) (Bahram, 2000). The fold of MICA forms two structural domains: the $\alpha 1 \alpha 2$-platform domain and the C-type immunoglobulin-like $\alpha 3$ domain (Figure 1.6.) (Li et al., 2001). The MICA crystal structure revealed that this platform consists of four distinct $\alpha$ helices arranged on an eight-stranded antiparallel $\beta$ sheet (Li et al., 1999). However, MICA does not associate with $\beta_{2}$-microglobulin - the light chain of MHC class I molecules - and does not present peptides (Groh et al., 1996; Groh et al., 1999). $\mathrm{Li}$ and collaborators demonstrated that the homodimeric NKG2D receptor binds diagonally across the $\alpha$-helical surface of the MICA platform domain in an interaction which is analogous to that seen in TCR-MHC class I protein complexes (Li et al., 2001). Figure 1.6 shows the crystal structure of human NKG2D in complex with MICA indicating that similar surfaces on each NKG2D monomer interact with different surfaces on either the $\alpha 1$ or $\alpha 2$ domain of a MICA protein. The MICA-NKG2D interface consists of a mixture of polar, hydrophobic and ionic interactions. The high overall complementarity at the binding site surfaces was much greater than Ab-antigen, TCR-ligand or other NCR-ligand interactions. Furthermore, the binding of NKG2D to MICA is of higher stability and avidity compared to many immunoreceptor-ligand interactions. None of the three NKG2D or eight MICA potential $N$ linked glycosylation sites lay near the interface. 
A

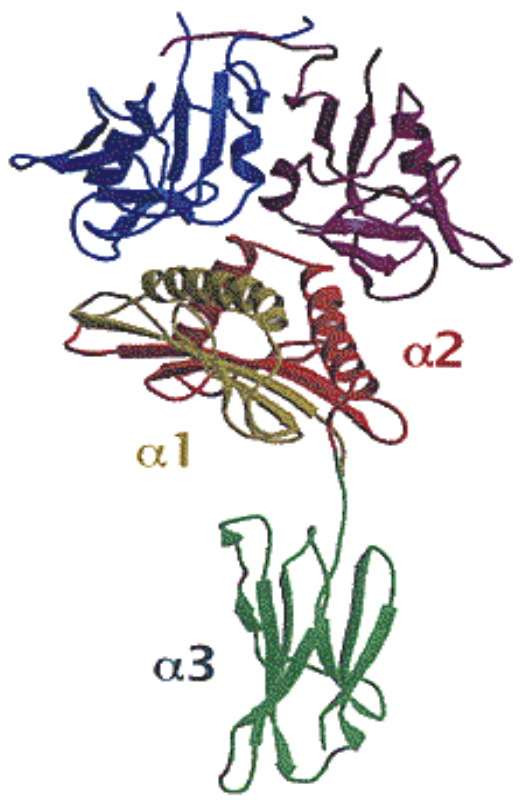

B

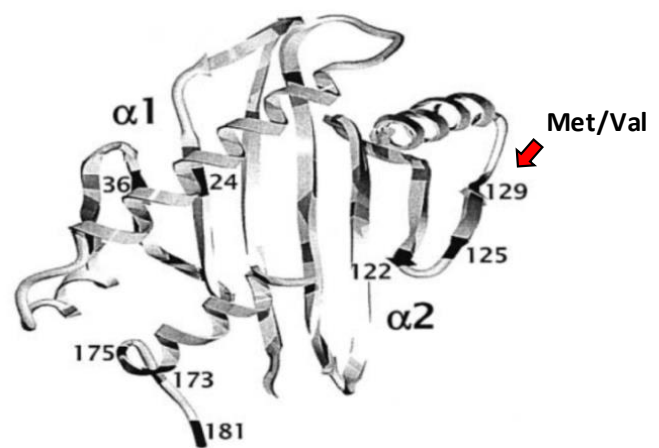

Figure 1.6: Crystal structure of the human MICA-NKG2D complex and human MICA alone.

(A) Side view of ribbon representation of the structure of the human NKG2D receptor in complex with its ligand MICA. Each NKG2D monomer interacts with either the $\alpha 1$ or $\alpha 2$ domain of a MICA protein. MICA domains are labeled and colored by domain ( $\alpha 1$, yellow; $\alpha 2$, red; $\alpha 3$, green). NKG2D is a homodimer consisting of two monomers as illustrated by different colors (NKG2D-A monomer, blue; NKG2D-B monomer, purple). Adapted from (Li et al., 2001). (B) Amino acid position Met/Val 129, depicted on a ribbon diagram of the MICA crystal structure, is located in the $\beta 4$ strand of the $\beta$-pleated sheet in the $\alpha 2$ domain of the protein. Adapted from (Steinle et al., 2001).

\subsubsection{MICA polymorphisms - MICA-129Met/Val dimorphism}

The MICA gene is the most polymorphic non-classical MHC class I gene in humans (Choy and Phipps, 2010). Currently 93 MICA alleles are known encoding for 72 protein variants (IMGT/HLA database; http://www.ebi.ac.uk/imgt/hla/). MICA has a triplet repeat microsatellite polymorphism $(\mathrm{GCT})_{\mathrm{n}}$ in the transmembrane region (encoded by exon 5; see above, Figure 1.5), which consists of alleles with four up to ten GCT repetitions or five repetitions with an additional nucleotide insertion, resulting in a premature stop codon and subsequent in a truncated MICA protein, designated as A4-10 or A5.1, respectively (Mizuki et al., 1997). Furthermore, the MICA gene contains several polymorphic positions within the exon 2, 3 and 4 which encode the three extracellular domains of the protein and which therefore might affect the MICA-NKG2D interaction (Table 1.1). These positions are mainly single amino acid substitutions (except positions 90 and 91), giving rise to dimorphic positions (except positions 156 and 251), and many of which are non-conservative changes (Choy and Phipps, 2010). The $\alpha 2$ domain exhibits the highest number of polymorphic positions which can be found in the $\beta$ strands, coils as well as $\alpha$ helices. Interestingly, the top surface of MICA, which is the binding 
site for NKG2D, harbors the most variable positions with at least one polymorphic position (position 156) interacting directly with the NKG2D receptor (Li et al., 2001).

Table 1.1: Amino acid substitutions in extracellular domains of the human MICA protein.

\begin{tabular}{|c|c|c|c|c|c|c|c|c|}
\hline \multicolumn{9}{|c|}{$\underline{\alpha 1 \text { domain encoded by exon } 2}$} \\
\hline $\begin{array}{l}\text { Codon: } \\
\text { MICA*01 } 01 \\
\text { Variant: }\end{array}$ & $\begin{array}{l}6 \\
\text { Arg } \\
\text { Pro } \\
\end{array}$ & $\begin{array}{l}14 \\
\text { Trp } \\
\text { Gly }\end{array}$ & $\begin{array}{l}24 \\
\text { Thr } \\
\text { Ala }\end{array}$ & $\begin{array}{l}26 \\
\text { Val } \\
\text { Gly }\end{array}$ & $\begin{array}{l}36 \\
\text { Cys } \\
\text { IVr }\end{array}$ & & & \\
\hline \multicolumn{9}{|c|}{$\underline{\alpha 2 \text { domain encoded by exon } 3}$} \\
\hline $\begin{array}{l}\text { Codon: } \\
\text { MlCA*A001 } \\
\text { Variant: }\end{array}$ & $\begin{array}{l}90 \\
\text { Leu } \\
\text { Phe }\end{array}$ & $\begin{array}{l}91 \\
\text { Gln } \\
\text { Arg }\end{array}$ & $\begin{array}{l}105 \\
\text { Arg } \\
\text { Lys }\end{array}$ & $\begin{array}{l}114 \\
\text { Gly } \\
\text { Arg }\end{array}$ & $\begin{array}{l}122 \\
\text { Leu } \\
\text { Val }\end{array}$ & $\begin{array}{l}\text { 124 } \\
\text { Thr } \\
\text { Ser }\end{array}$ & $\begin{array}{l}125 \\
\text { Lsy } \\
\text { Glu }\end{array}$ & $\begin{array}{l}129 \\
\text { Met } \\
\text { Val }\end{array}$ \\
\hline $\begin{array}{l}\text { Codon: } \\
\text { MICA*01 } 01 \\
\text { Variant: }\end{array}$ & $\begin{array}{l}\text { 142 } \\
\text { Val } \\
\text { Ile }\end{array}$ & $\begin{array}{l}151 \\
\text { Met } \\
\text { Val }\end{array}$ & $\begin{array}{l}156 \\
\text { His } \\
\text { Leu/Arg }\end{array}$ & $\begin{array}{l}173 \\
\text { Lys } \\
\text { Glu } \\
\end{array}$ & $\begin{array}{l}175 \\
\text { Gly } \\
\text { Ser }\end{array}$ & $\begin{array}{l}176 \\
\text { Val } \\
\text { Ile }\end{array}$ & $\begin{array}{l}181 \\
\text { Thr } \\
\text { Arg }\end{array}$ & \\
\hline \multicolumn{9}{|c|}{$\underline{\alpha 3 \text { domain encoded by exon } 4}$} \\
\hline $\begin{array}{l}\text { Codon: } \\
\text { MlCA**01 } \\
\text { Variant: }\end{array}$ & $\begin{array}{l}206 \\
\text { Gly } \\
\text { Ser }\end{array}$ & $\begin{array}{l}208 \\
\text { Tyr } \\
\text { Cys }\end{array}$ & $\begin{array}{l}210 \\
\text { Trp } \\
\text { Arg }\end{array}$ & $\begin{array}{l}213 \\
\text { Thr } \\
\text { le }\end{array}$ & $\begin{array}{l}215 \\
\text { Ser } \\
\mathrm{Thr}\end{array}$ & $\begin{array}{l}221 \\
\text { Val } \\
\text { Leu }\end{array}$ & $\begin{array}{l}230 \\
\text { Trp } \\
\text { Ser } \\
\end{array}$ & $\begin{array}{l}251 \\
\mathrm{Gln} \\
\mathrm{Arg} / \mathrm{Gl}\end{array}$ \\
\hline $\begin{array}{l}\text { Codon: } \\
\text { MlCA**01 } \\
\text { Variant: }\end{array}$ & $\begin{array}{l}256 \\
\text { Arg } \\
\text { Ser }\end{array}$ & $\begin{array}{l}268 \\
\text { Ser } \\
\text { Gly }\end{array}$ & $\begin{array}{l}271 \\
\text { Pro } \\
\text { Ala }\end{array}$ & & & & & \\
\hline
\end{tabular}

Non-conservative amino acid substitutions are underlined. Adapted from (Choy and Phipps, 2010).

The single nucleotide polymorphism (SNP; rs1051792; $A \rightarrow G$ ) at position 454 of the MICA gene leading to a single amino acid substitution of methionine (Met) by valine (Val) at position 129 of the protein, designated as MICA-129Met/Val polymorphism, is of particular interest, since Steinle and colleagues revealed the Met variant as strong and the Val variant as weak binder of NKG2D. The amino acid 129 is located in the $\beta 4$ strand of the $\beta$-pleated sheet in the $\alpha 2$ domain of the MICA protein as shown in Figure 1.6 B (Li et al., 1999; Li et al., 2001). The side chain of Met 129 is partially buried and forms hydrophobic interactions with glutamine (Glu) 136, alanine (Ala) 139 and Met 140. Therefore, its replacement by Val likely affects NKG2D binding indirectly by a conformational change (Steinle et al., 2001).

\subsubsection{Associations of MICA polymorphisms with diseases}

MICA polymorphisms have been associated with several diseases related to NK cell activity, such as viral infection, cancer, autoimmune disease and allograft rejection or graft-versus-host disease (GVHD). Underlying mechanisms include NK cell-mediated cytotoxicity and the MICA shedding phenomenon producing SMICA with immunosuppressive functions (see section 1.1.5) (Choy and Phipps, 2010). 
However, because of the proximity of the MICA gene to HLA-B and HLA-C, which are associated with various disorders, it is necessary to perform large and multi-ethnic disease studies on MICA polymorphisms to exclude HLA class I gene associations. Initial MICA polymorphism and disease association studies were undertaken only in small cohorts or single-ethnic groups and/or which did not take into account possible HLA class I gene associations, associated autoimmune diseases, such as Behçet's disease (Mizuki et al., 1997) and ankylosing spondylitis (Goto et al., 1997), with MICA polymorphisms. Later studies however suggested that these diseases were primarily associated with $H L A-B$ alleles and that the perceived disease association with MICA alleles was due to linkage disequilibrium with HLA-B (Wallace et al., 1999; Salvarani et al., 2001; Mizuki et al., 2007) or only secondary (Martinez-Borra et al., 2000), respectively.

Table 1.2: SNPs in MICA alleles associated with human diseases.

\begin{tabular}{|c|c|c|c|c|}
\hline SNP & Disease & Effect & Population & Reference \\
\hline MICA-129Met & Early onset ankylosing spondylitis & Susceptibility & Algerian & Amroun et al., 2005 \\
\hline MICA-129Val & Chronic graft-versus-host disease & Susceptibility & French & Boukouaci et al., 2009 \\
\hline MICA-129Val & Nasopharyngeal carcinoma & Susceptibility & Tunisian & Douik et al., 2009 \\
\hline MICA-129Met & Inflammatory bowel disease & Susceptibility & Spanish & Lopez-Hernandez et al., 2010 \\
\hline MICA-129Met & Systemic lupus erythematosus & Susceptibility & Japanese & Yoshida et al., 2011 \\
\hline MICA-129Val & Ulcerative colitis & Susceptibility & Chinese & Zhao et al., 2011 \\
\hline MICA-129Val & Type 1 and latent autoimmune diabetes & Susceptibility & Algerian & Raache et al., 2012 \\
\hline MICA-129Met & Psoriatic disease & Susceptibility & Canadian & Pollock et al., 2013 \\
\hline MICA-173Lys & Rheumatoid arthritis & Protection & French, German & Kirsten et al., 2009 \\
\hline $\begin{array}{l}\text { MICA-213Thr } \\
\text { MICA-251Gln }\end{array}$ & Cervical cancer & Protection & Northeastern Thai & Jumnainsong et al., 2007 \\
\hline MICA*A5 & Leukemia & Susceptibility & Southern Chinese & Luo et al., 2011 \\
\hline MICA*A5.1 & Oral squamous cell carcinoma & Susceptibility & Japanese & Tamaki et al., 2007 \\
\hline MICA*A5.1 & Breast cancer & Susceptibility & Spanish & Lavado-Valenzuela et al., 2009 \\
\hline MICA*A5.1 & Hepatocellular carcinoma & Susceptibility & Southern Chinese & Jiang et al., 2011 \\
\hline MICA*A9 & Nasopharyngeal carcinoma & Susceptibility & Southern Chinese & Tian et al., 2006 \\
\hline
\end{tabular}

Nevertheless, more refined studies also showed associations of MICA polymorphisms with infections, malignant and autoimmune disorders (Table 1.2). For instance, it has been reported that a SNP, MICA-173Lys, confers protection against rheumatoid arthritis in French and German populations independent of known HLA-DRB1 risk alleles (Kirsten et al., 2009). Jumnainsong et al. (2007) observed that two SNPs encoding the $\alpha 3$ domain, MICA-213Thr and MICA-251Gln, are negatively associated with cervical cancer. Furthermore, different microsatellite polymorphisms in the transmembrane region of the MICA gene were found to be associated with different cancer types. For example, MICA*A5 and MICA*A9 in southern Chinese Han populations are reported to be 
associated with an increased susceptibility to leukemia (Luo et al., 2011) or nasopharyngeal carcinoma (Tian et al., 2006), respectively. Especially the MICA*A5.1 polymorphism, giving rise to a truncated MICA protein, was shown to be associated with oral squamous cell carcinoma in Japanese patients (Tamaki et al., 2007 and 2009), breast cancer in Spanish women (Lavado-Valenzuela et al., 2009) and hepatocellular carcinoma in a South China Han population (Jiang et al., 2011). Some of these studies additionally revealed a relationship between cancer patients carrying the MICA*A5.1 polymorphism and increased serum levels of sMICA (Tamaki et al., 2009; Jiang et al., 2011).

The MICA-129Met/Val polymorphism, which affects NKG2D binding avidity (Steinle et al., 2001), has been associated with malignancies and autoimmune diseases independently of HLA class I and class II gene associations (Table 1.2).

The Val variant of the MICA-129 dimorphism was found to be associated with increased susceptibility to nasopharyngeal carcinoma in a Tunisian population (Douik et al., 2009). Since MIC molecules are not specifically tumor-associated antigens (Schrambach et al., 2007), the observed association of the MICA-129Val variant with this type of cancer can be therefore better explained by the reduced NKG2D avidity and possibly also by the MICA shedding phenomenon (Choy and Phipps, 2010).

Furthermore, a number of autoimmune diseases, including ankylosing spondylitis, rheumatoid arthritis, inflammatory bowel disease, systemic lupus erythematosus, type 1 diabetes and latent autoimmune diabetes and psoriatic disease, have been associated with the MICA-129Met/Val polymorphism. In this context, the MICA-129Met variant was observed to be associated with an increased susceptibility to early onset ankylosing spondylitis in a cohort of Algerian patients independently of HLA-B*27 (Amroun et al., 2005). Lopez-Hernandez et al. (2010) found a higher frequency of the MICA-129Met/Met genotype in Spanish patients with inflammatory bowel disease (mainly in ulcerative colitis). Zhao et al. (2011) showed that the MICA-129Val/Val genotype was more frequent in Chinese patients with ulcerative colitis and that these patients had also higher serum levels of sMICA compared to those with the Met/Val or Met/Met genotype. A Japanese study described that the MICA-129Met allele was positively associated with systemic lupus erythematosus in contrast to the Val allele showing a negative association (Yoshida et al., 2011). Additionally, also the frequency of the MICA-129Val variant was increased in Algerian patients with type 1 diabetes and latent autoimmune diabetes in adults than in the control group (Raache et al., 2012). Pollock and collaborators investigated whether MICA-129 was differentially associated with skin and joint manifestations of psoriatic disease independently of $H L A-C$ and $H L A-B$ in two Canadian Caucasian cohorts and found that the Met allele, particular Met/Met homozygosity, was associated with cutaneous psoriasis in Toronto patients (Pollock et al., 2013). 
Introduction

Moreover, an association between the MICA-129Val/Val genotype and an increased risk of chronic GVHD (cGVHD) after hematopoietic stem cell transplantation (HSCT) in a French cohort of cancer patients has been reported (Boukouaci et al., 2009) (see section 1.3.3). Independently of the Val/Val genotype also elevated sMICA serum levels were shown to associate with the incidence of cGVHD.

\subsection{Therapy of cancer - NK cells and MICA polymorphisms}

The knowledge that NK cells can rapidly respond to the presence of tumor cells and participate in tumor immunosurveillance has prompted efforts to harness NK cell functions for the development of improved strategies in the treatment of cancer patients. NK cell-based therapeutic approaches are relatively new in cancer therapy (Terme et al., 2008). Besides monoclonal antibody-based therapies, which indicate that NK cell-mediated ADCC contributes to the beneficial antitumor response (Cartron et al., 2002; Veeramani et al., 2011), adoptive tumor immunotherapies focusing on the manipulation of NK cells and strategies targeting NK cell activation receptors or their ligands represent potentially promising approaches in cancer therapy.

\subsubsection{NK cells in immunotherapy of cancer}

Allogeneic hematopoietic stem cell transplantation (HSCT) is an efficient form of an immunotherapy and currently the only potentially curative treatment of many hematological malignancies (Dickinson, 2008). NK cells make important contributions to graft-versus-leukemia (GVL) effects after allogeneic HSCT (Warren et al., 2012) without inducing graft-versus-host disease (GVHD) (Dong et al., 2009; Vivier et al., 2012). This feature possibly results from the differential distribution of ligands for NK activation receptors on hematopoietic and non-hematopoietic cells (Dong et al., 2009; Vivier et al., 2012). 'Haplo-identical' transplantation is one type of allogeneic HSCT, in which the related donor and recipient share only one HLA haplotype, and which has highlighted the potential of NK cells in tumor immunosurveillance. In a 'KIR ligand-mismatched' situation, subsets of donor-derived NK cells, which are not inhibited by host MHC class I molecules, exert GVL effects (Figure 1.7 A) (Vivier et al., 2012). The positive effect of KIR incompatibility in haplo-identical T cell-depleted HSCT has been demonstrated in various studies of patients with acute myeloid leukemia (AML) (Ruggeri et al., 2002; Giebel et al., 2003; Ruggeri et al., 2007) or multiple myeloma (Kröger et al., 2005). Nevertheless, HLAidentical or HLA-matched HSCT is still the most frequent HSCT approach for cancer patients, whereas 
haplo-identical HSCT is used for only a minor subset of patients with poor-prognosis because of their high transplant-related mortality (Vivier et al., 2012).

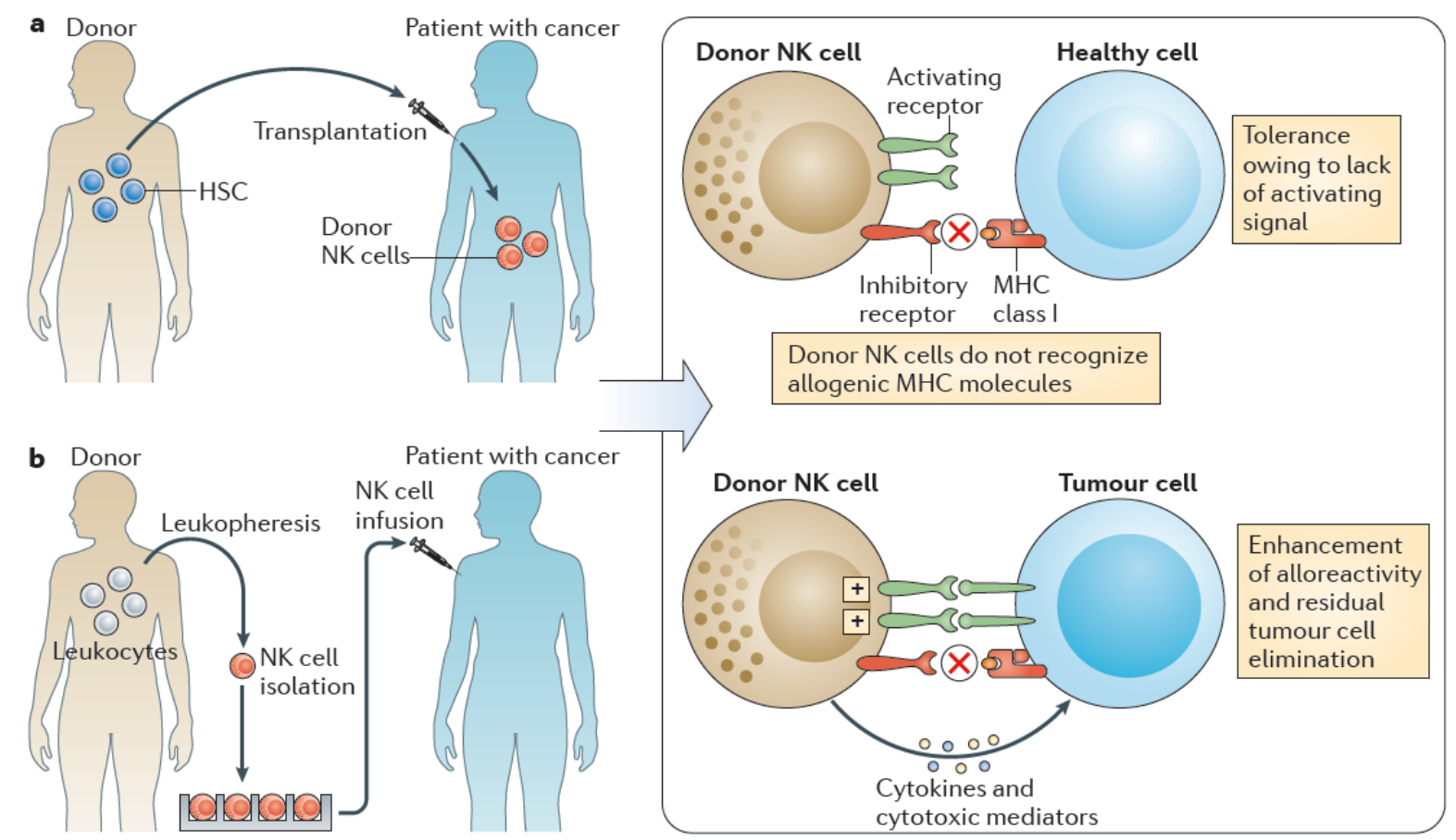

Figure 1.7: Cancer therapies targeting NK cells.

(A) Following haplo-identical or MHC-matched HSCT, NK cells of donor origin develop in the cancer patient. (B) Alternatively, NK cell populations can be isolated from healthy donors and activated and/or expanded in vitro before infusion into the patient with cancer. In both cases (allogeneic HSCT and NK cell infusion), the aim is to promote the antitumor function of donor NK cells in the patient. Indeed, a fraction of donor NK cells will be not be inhibited by the MHC class I molecules of the patient, as the KIRs expressed by the donor NK cells will not interact with the MHC class I molecules of the patient, and this promotes tumor cell elimination. In contrast, to cancer cells, most healthy cells of the patient will not activate donor NK cells, as they lack a sufficient cellsurface density of activating ligands for the donor NK cells. Adapted from (Vivier et al., 2012).

NK cells are considered as promising therapeutic tools for tumor immunotherapy also independently of HSCT (Terme et al., 2008). They can be isolated from healthy donors and subsequently activated and/or expanded in vitro before infusion into the recipient (Figure $1.7 \mathrm{~B}$ ). In this context, allogeneic NK cell transfer is preferred to autologous transfer because it is known that the cytotoxic potential of autologous NK cells is weak compared to allogeneic NK cells (Groth et al., 2011). However, to obtain long-term cancer control it is necessary to increase the survival of the NK cells in the recipient. NK cell function could be improved by cytokine stimulation, especially IL-2 treatment, leading to an increased NK cell cytotoxicity and antitumor response (Fehniger et al., 2002; Huenecke et al., 2010). Several protocols of clinical-grade NK cell purification and in vitro population expansion are validated and various studies have demonstrated that the infusion of allogeneic NK cells in humans is safe 
(Vivier et al., 2012). Furthermore, it has been shown that the adoptive transfer of mature HLAmismatched NK cells into cancer patients is also well tolerated (Miller et al., 2005). These findings suggest that allogeneic NK cell transfer might be a beneficial antitumor strategy.

Altogether, the efficacy of NK cell-based tumor therapies has not been firmly established, yet. However, as shown by several different studies NK cells represent potential targets for tumor immunotherapy and the achievements regarding conditioning regimes justify the present attempts to further develop and improve approaches focusing on the manipulation of NK cells. For instance, new protocols might include monoclonal Ab cancer therapies in combination with HLA-identical or non-identical HSCT, with adoptive NK cell transfer or with drugs inducing the expression of ligands for NK activation receptors (Vivier et al., 2012).

\subsubsection{Targeting of NKG2D or its ligands for cancer therapy}

The activating NK cell receptor NKG2D and expression of its ligands play an important role in antitumor immune responses. Findings from a comprehensive study of hematopoietic malignancies found heterogeneous surface expression of at least one NKG2D ligand type in about 75\% of leukemia patients (Hilpert et al., 2012). In addition, data from distinct solid tumors suggest that MICA is one of the most frequent NKG2D ligands (Gonzalez et al., 2006; Nausch and Cerwenka, 2008). Because NK cells do not effectively eliminate tumors in cancer patients, new strategies aim to increase both NK cell activation and tumor cell visibility to NK cells (Cerwenka, 2009). One approach is the selective upregulation of NKG2D ligands using antitumor agents, such as DNA damage-inducing cisplatin and 5fluorouracil (Gasser et al., 2005), or genotoxic drugs, including histone deacetylase (HDAC) inhibitors (Armeanu et al., 2005), or proteasomal inhibitors (Armeanu et al., 2005 and 2008; Nice et al., 2009). HDAC inhibitors have emerged as a powerful new class of small-molecule therapeutics. Over 490 clinical trials have been initiated in the last 10 years, culminating in the approval of two distinct HDAC inhibitors; suberoylanilide hydroxyamic acid (SAHA; also known as vorinostat, Zolinza ${ }^{\mathrm{TM}}$ ) and FK228 (romidepsin, Istodax ${ }^{\mathrm{TM}}$ ) (Gryder et al., 2012). A further therapeutic approach to enhance NK cellmediated cytotoxicity is the usage of bifunctional fusion proteins comprising of a NKG2D ligand and a single-chain antibody fragment (scFv) targeting a specific tumor cell surface marker (El-Gazzar et al., 2013). An example is ULBP2/anti-syndecan-1 (CD138) scFv, also known as ULBP2/BB4, which activates and targets NK cells to the malignant cells in multiple myeloma. While ULBP2 binds NKG2D, the BB4 moiety binds to CD138 which is over-expressed on a variety of malignancies (von Strandmann et al., 2006). Since soluble NKG2D ligands can be found in the serum of some cancer 
patients and can lead to down-regulation of NKG2D (see section 1.1.5), another approach aims at the neutralization of these soluble immunosuppressive particles using specific Abs against the corresponding ligands (El-Gazzar et al., 2013). These approaches in combination with other NK cellactivating regimes and/or adoptive NK cell transfer might improve current clinical strategies in the treatment of cancer.

\subsubsection{Importance of MICA polymorphisms in HSCT}

Allogeneic HSCT offers an option for cure of several hematopoietic diseases. Currently it relies mainly on the HLA matching of donors and recipients which is essential to reduce the risk of graft rejection and GVHD and therefore to increase overall survival (Petersdorf et al., 1998; Sasazuki et al., 1998; Morishima et al., 2002). However, also minor histocompatibility antigens (mHags) can affect transplant outcome playing a role in both GVHD and GVL mechanisms (Warren et al., 2012). Moreover, genetic polymorphisms can influence the success of transplantations. An increasing number of studies in the last 15 years have demonstrated the impact of SNPs or microsatellites of cytokines, cytokine receptor genes or other non-HLA encoded genes including those of the innate immune system on the outcome of HSCT (Dickinson, 2008). Those SNPs, which alter the regulation of genes or the function of proteins, might not only be useful to predict risks but also to identify pathophysiological pathways, which could be targeted by new therapies. For instance, several SNPs in the TNF- $\alpha$ gene encoded in the HLA class III region, e.g., have been associated with an increased risk of GVHD and some of them lead to an increased expression of this pro-inflammatory cytokine, which might explain the observed association with GVHD (Dickinson, 2008).

In the context of MICA, it has been reported that MICA and MICB genotype matching increased the survival after HSCT (Kitcharoen et al., 2006), whereas MICA mismatching increased the incidence of acute GVHD (aGVHD) (Parmar et al., 2009) although not in all studies (Anderson et al., 2009). An approach which does not only take into account HLA matching but also non-HLA DNA polymorphisms in the MHC loci as markers of blocks of ancestral haplotypes, such as beta block (the region including $H L A-B, H L A-C, M I C A$ and $M I C B$ ) and delta block (the region including HLA-DR and HLA-DQ), is the DNA-based MHC block matching technique (Tay et al., 1995). MHC beta block matching was found to be the marker for MIC genes and correlated with MIC matching additionally to matching of HLA-B and HLA-C (Gaudieri et al., 2001; Kitcharoen et al., 2006). For instance, the survival of HSCT patients who were matched for $H L A-B, H L A-C, H L A-D R$ and $H L A-D Q$ was improved further with additional matching for beta block, MIC or both (Kitcharoen et al., 2006). Furthermore, as referred to before 
(see section 1.2.3) the MICA-129 dimorphism was found to be associated with the incidence of cGVHD and relapse after HSCT in a French cohort of cancer patients (Boukouaci et al., 2009). The risk of developing cGVHD was increased for recipients with the MICA-129Val/Val genotype and the risk of relapse was increased for the MICA-129Met/Met genotype. Independently of the Val/Val genotype also elevated SMICA serum levels were shown to be associated with the incidence of cGVHD, whereby the presence of anti-MICA Abs before transplantation was associated with protection against cGVHD (Boukouaci et al., 2009). Since MICA polymorphisms do not only feature significantly in disease associations but also in donor-recipient matching for transplantation, matching of MICA alleles of donors and recipients should be taken into consideration alongside other HLA matching techniques to obtain better post-transplant outcomes.

\subsection{Objectives}

Numerous studies have demonstrated the impact of SNPs on the outcome of HSCT. Such SNPs might be useful to predict risks and to identify new targets for therapy. One candidate of interest is the highly polymorphic MICA gene. In this study, we focused on the MICA-129Met/Val polymorphism which has been associated previously with the risk of cGVHD and could be causative itself due to a higher avidity of MICA-129Met than MICA-129Val variants to NKG2D. Since MICA is a ligand of the activating NK cell receptor NKG2D and NK cells have also been reported to play a crucial role in HSCT, it is furthermore important to understand the biological relevance of this SNP regarding NK cell responses.

The aim of this project therefore was to determine the impact of the MICA-129 dimorphism on effector functions of NK cells. We wanted to analyze whether the two MICA-129 variants differ in their ability to trigger NK cell responses, including NKG2D-mediated signaling, cytotoxicity and cytokine release. For these experiments, recombinant MICA-129-Fc fusion proteins and MICA-129transfected tumor cell lines of both variants were constructed.

Moreover, we wanted to address the question whether the MICA-129Met/Val dimorphism affects the outcome of allogeneic HSCT in a cohort of patients from the University Medical Center Göttingen to determine whether this SNP could serve as biomarker for the risk assessment of allogeneic HSCT. 


\section{Materials and Methods}

\subsection{Materials}

If not specified otherwise, all supplier places are located in Germany.

\subsubsection{General equipment}

Table 2.1: General equipment

\begin{tabular}{|c|c|c|}
\hline Description & Label & Supplier \\
\hline $\begin{array}{l}\text { Agarose gel electrophoresis } \\
\text { system }\end{array}$ & Perfect Blue ${ }^{\mathrm{TM}}$ Gel System & Peglab Biotechnology \\
\hline Aqua bidest. Supply & arium $^{\oplus}$ pro & Sartorius AG \\
\hline Autoclave & High pressure steam sterilisator FVS & Integra Biosciences \\
\hline Biological Safety Cabinet & HERASave $^{\circledR}$ & Thermo Fisher Scientific \\
\hline \multirow{7}{*}{ Centrifuges } & $3 \mathrm{~K} 30$ & Sigma \\
\hline & Megafuge $1.0 \mathrm{R}$ for 96 -well plates & Heraeus \\
\hline & Mini Centrifuge MCF-2360 & LMS Consult \\
\hline & Multifuge $1 \mathrm{~b}$ & \multirow{2}{*}{ Heraeus } \\
\hline & Multifuge $3 \mathrm{~S}-\mathrm{R}$ & \\
\hline & RC 3B Plus & Sorvall \\
\hline & Refrigerated Microcentrifuge 5417R & Eppendorf \\
\hline Counting chamber & Neubauer improved & Krannich \\
\hline Dispenser & Multipette ${ }^{\circledR}$ plus & Eppendorf \\
\hline Electroporation system & GenePulser ${ }^{\oplus}$ /I \& Cap. Extender & Bio-Rad Laboratories \\
\hline Flow Cytometer & FACS Calibur & BD Biosciences \\
\hline \multirow{3}{*}{ Freezer } & HERA freeze $-80^{\circ} \mathrm{C}$ & Heraeus \\
\hline & Liebherr Comfort $-20^{\circ} \mathrm{C}$ & Liebherr GmbH \\
\hline & VIP plus $-150^{\circ} \mathrm{C}$ & SANYO Electric Co., Japan \\
\hline Homogenizer & Tenbroeck & schuett-biotec \\
\hline Im zaing devicec & Chemilux Blot Detection Imager & \multirow{2}{*}{ Intas Science Imaging } \\
\hline imaging aevices & UV workbench Gellmager & \\
\hline Incubators & HERACell ${ }^{\circledR} 150 \mathrm{CO}_{2}$ & Heraeus \\
\hline Incubator shaker & Unitron-plus & Infors \\
\hline Liquid Scintillation Counters & $\begin{array}{l}\text { MicroBeta Trilux } 1450 \\
\text { MicroBeta }{ }^{2} \text { Plate Counter }\end{array}$ & PerkinElmer, USA \\
\hline MACS separator & SuperMACS ${ }^{\mathrm{TM}}$ Separator & MACS Miltenyi Biotec \\
\hline Magnetic stirrer/heater & RH basic 2 & IKA \\
\hline Microscope & Axiovert 35 & Zeiss \\
\hline Microwave & HF12M 900W & Siemens \\
\hline pH-Meter & inoLab $^{\circledast}$ pH Level 1 & WTW \\
\hline
\end{tabular}




\begin{tabular}{lll}
\hline $\begin{array}{l}\text { Pipettes } 2 \mu \mathrm{l}, 20 \mu \mathrm{l}, 200 \mu \mathrm{l}, \\
1000 \mu \mathrm{l}\end{array}$ & Research $^{\circledR}$ \& Reference \\
\hline Pipettor & IBS PIPETBOY acu & Eppendorf \\
\hline Power supplies & $\begin{array}{l}\text { EPS-301/-3501 XL } \\
\text { Electrophoresis power supply }\end{array}$ & $\begin{array}{l}\text { Integra Biosciences } \\
\text { Amersham BioSciences }\end{array}$ \\
\hline Scales & ACCULAB Vicon & Sartorius \\
\hline SDS gel chambers & BP 61 & GE Healthcare \\
\hline \multirow{2}{*}{ Spectrophotometer } & Hoefer SE600 Ruby & Eppendorf \\
& BioPhotometer & Thermo Fisher Scientific \\
\hline SPR biosensor & NanoDrop ${ }^{\text {TM ND-1000 }}$ & BioTek \\
\hline & PowerWave 340 microplate reader & Reichert Technologies \\
\hline Thermal Cycler & SR7500DC & Applied Biosystems, USA \\
& ABI 7500 Real-Time PCR System & Eppendorf \\
\hline Thermoblocks & ABI 7900HT Fast Real-Time PCR & Biometra \\
\hline Vortexer & MasterCycler epgradient & Eppendorf \\
\hline Water bath & TPersonal 48 & Bibby Scientific \\
\hline Western blot device & Thermomixer comfort & IKA \\
\hline
\end{tabular}

\subsubsection{Consumables}

Table 2.2: Consumables

Label

2D HC 1000m sensorchip for SPR

6-well tissue culture plates, F-bottom

24-well tissue culture plates, F-bottom

96-well MaxiSorp ${ }^{\text {TM }}$ microtiter plates

96-well optical reaction plates for qRT-PCR

96-well suspension culture plates, F-bottom

96-well suspension culture plates, U-bottom

96-well tissue culture plates, V-bottom

96-well Wallac OptiPlates

384-well plates for TaqMan ${ }^{\circledR}$ Genotyping Assay

Adhesive sealing film for Wallac plates

Amicon ultra-15 centrifugal filter units (30 kDa)

Cell culture flasks $(250 \mathrm{ml})$

Cell culture plates $(3.5 \mathrm{~cm}, 6 \mathrm{~cm}, 10 \mathrm{~cm})$

Cellstar ${ }^{\circledR}$ sterile pipettes $(1 \mathrm{ml}, 2 \mathrm{ml}, 5 \mathrm{ml}, 10 \mathrm{ml}, 25 \mathrm{ml}$ )

Cell strainer $(40 \mu \mathrm{m})$

Cover slips

\section{Supplier}

Xantec Bioanalytics

Greiner bio-one $\mathrm{GmbH}$

Greiner bio-one $\mathrm{GmbH}$

Nunc

Applied Biosystems, USA

Greiner bio-one $\mathrm{GmbH}$

Greiner bio-one $\mathrm{GmbH}$

Sarstedt

PerkinElmer, USA

Applied Biosystems, USA

PerkinElmer, USA

Merck Millipore

Sarstedt

Greiner bio-one $\mathrm{GmbH}$

Greiner bio-one $\mathrm{GmbH}$

BD Biosciences

Sarstedt 
Cryo tubes

Electroporation cuvette (4 $\mathrm{mm}$ gap)

FACS tubes

Falcon conical tubes $(15 \mathrm{ml}, 50 \mathrm{ml})$

Filter units $(0.2 \mu \mathrm{m}, 0.45 \mu \mathrm{m})$

Gel blotting paper GB 003

HiTrap ${ }^{\circledR}$ Protein $\mathrm{G}$ column (1 ml)

Leucosep ${ }^{\circledR}$ Tubes with porous barrier $(50 \mathrm{ml})$, conical bottom

MACS LS columns

Membrane adapter

Microscope slides

Multipette ${ }^{\circledR}$ plus Combitips

Needles 21 G x 1 1/2", 22 G x 1 1/4", 26 G x 1/2", 30 G x 1/2"

Optical adhesive covers for qRT-PCR plates

Parafilm ${ }^{\circledR}$

Pasteur pipettes

Pipette tips $(10 \mu \mathrm{l}, 200 \mu \mathrm{l}, 1000 \mu \mathrm{l})$

Plastic tubes ( $13 \mathrm{ml})$

Reaction tubes $0.5 \mathrm{ml}$

Reaction tubes $(1.5 \mathrm{ml}, 2 \mathrm{ml})$

Roti ${ }^{\circledR}$-Nitrocellulose membrane

Safety-Multifly ${ }^{\circledR}$-Set

SERVAPOR ${ }^{\circledast}$ dialysis tubing (12-14 MWCO)

Syringes ( $1 \mathrm{ml})$

Syringes $(1 \mathrm{ml}, 2 \mathrm{ml}, 5 \mathrm{ml}, 10 \mathrm{ml}, 20 \mathrm{ml}$ )

UVette $^{\circledR}$

Weighing paper
Greiner bio-one $\mathrm{GmbH}$

Peqlab Biotechnology

BD Biosciences / Sarstedt

Greiner bio-one $\mathrm{GmbH}$

Greiner bio-one $\mathrm{GmbH}$

Whatman, Schleicher \& Schuell

GE Healthcare

Greiner bio-one $\mathrm{GmbH}$

MACS Miltenyi Biotec

Sarstedt

Menzel

Eppendorf

B. Braun Melsungen AG

Applied Biosystems, USA

Pechiney Plastic Packaging

Wilhelm Ulbrich Mainz

Greiner bio-one GmbH / Sarstedt

Sarstedt

Sarstedt

Greiner bio-one GmbH

Carl Roth

Sarstedt

SERVA Electrophoresis GmbH

Henke Sass Wolf

BD Biosciences

Eppendorf

Machery-Nagel

\subsubsection{Chemicals and reagents}

All chemicals and reagents used in this study were of pro analysis quality and are listed in the Table 2.3.

Table 2.3: Chemicals and reagents

Chemical/Reagent

2,2'-azino-bis(3-ethylbenzothiazoline-6-sulphonic acid) (ABTS)

$2-\beta$-Mercaptoethanol

$3,3^{\prime}$-diaminobenzidine (DAB)

4-amino-3-(4-chlorophenyl)-1-(t-butyl)-1H-pyrazolo[3,4-d]

pyrimidine (PP2)

Agar-Agar, Kobe I

Ammonium chloride $\left(\mathrm{NH}_{4} \mathrm{Cl}\right)$

Ammonium persulfate (APS)
Supplier

AppliChem

SIGMA-Aldrich ${ }^{\circledR}$

Carl Roth

SIGMA-Aldrich ${ }^{\circledast}$

Carl Roth

Merck

Serva 
Ampicillin sodium salt $\left(\mathrm{C}_{16} \mathrm{H}_{18} \mathrm{~N}_{3} \mathrm{NaO}_{4} \mathrm{~S}\right)$

Bio-Rad Protein Assay reagent

Bovine serum albumin (BSA)

Bromphenol Blue ( $\mathrm{Na}^{+}$-salt)

Chloroform

Citric acid $\left(\mathrm{C}_{6} \mathrm{H}_{8} \mathrm{O}_{7}\right)$

Coomassie Brilliant Blue R-250

Dimethyl sulfoxide (DMSO)

dNTPs

Eosin

Ethanol (EtOH)

Ethidium bromide

Ethylenediaminetetraacetic acid (EDTA)

FACSflow

FACS $^{\text {TM }}$ Lysis solution

Fetal calf serum (FCS)

Formalin

GeneRuler 1kb DNA ladder

Geneticin (G418 Sulfate)

$\mathrm{GIBCO}^{\circledast}$ Penicillin/Streptomycin

Glycerol

Glycine

Heparin sodium

Hexadimethrine bromide (Polybrene)

Hydrochloric acid ( $\mathrm{HCl})$

Isoamyl alcohol

Isopropanol

Kanamycin sulfate

Lithium chloride (LiCl)

Magnesium chloride $\left(\mathrm{MgCl}_{2}\right)$

Magnesium sulfate $\left(\mathrm{MgSO}_{4}\right)$

Mayer's hemalum solution

Methanol

Nonidet $^{\mathrm{TM}} \mathrm{P}-40$

para-coumaric acid

Paraffin

Phosphate-buffered saline (PBS)

Potassium chloride $(\mathrm{KCl})$

Potassium phosphate $\left(\mathrm{KH}_{2} \mathrm{PO}_{4}\right)$

Prestained protein marker, broad range

Propidium iodide (PI)

Pyruvat

Random primer

RNasin ${ }^{\circledR}$ Plus Ribonuclease Inhibitor

Roti ${ }^{\circledR}$-Histokitt
Carl Roth

Bio-Rad Laboratories

PAA Laboratories

Merck

Carl Roth

Carl Roth

SIGMA-Aldrich ${ }^{\circledast}$

Merck

$\mathrm{NEB}^{\circledR}$, USA

Merck

UMG Apotheke

HyClon

Carl Roth

BD Biosciences

BD Biosciences

PAA Laboratories

Carl Roth

Fermentas

Biochrom

Merck

Carl Roth

Carl Roth

Rotexmedica

Merck

Carl Roth

Merck

Merck

PAN $^{\text {TM }}$ BIOTECH GmbH

Carl Roth

Merck

SIGMA-Aldrich ${ }^{\circledast}$

Merck

Merck

SIGMA-Aldrich ${ }^{\circledast}$

SIGMA-Aldrich ${ }^{\circledR}$

Carl Roth

Biochrom

Carl Roth

Merck

$\mathrm{NEB}^{\circledR}$, USA

AppliChem

Biochrom

Promega

Promega

Carl Roth 
Roti $^{\circledR}$-Phenol

Rotiphorese ${ }^{\circledR}$ Gel 30 (37.5:1)

Scintillator Optiphase HiSafe 3

Sodium azide $\left(\mathrm{NaN}_{3}\right)$

Sodium carbonate $\left(\mathrm{Na}_{2} \mathrm{CO}_{3} / \mathrm{NaHCO}_{3}\right)$

Sodium chloride $(\mathrm{NaCl})$

Sodium chromate $\left(\mathrm{Na}_{2}{ }^{51} \mathrm{CrO}_{4}\right)$

Sodium citrate $\left(\mathrm{NaC}_{6} \mathrm{H}_{5} \mathrm{O}_{7}\right)$

Sodium hydroxide $(\mathrm{NaOH})$

Sodium phosphate $\left(\mathrm{Na}_{2} \mathrm{HPO}_{4} / \mathrm{NaH}_{2} \mathrm{PO}_{4}\right)$

Streptavidin-horseradish peroxidase (HRP)

Sucrose

TaqMan ${ }^{\circledR}$ Universal PCR Master Mix

TEMED (N,N,N',N'-tetramethyl-ethane-1,2-diamine)

TiterMax ${ }^{\circledR}$

Tris

Tris-buffered saline (TBS)

Triton X-100

TRIzol ${ }^{\circledR}$ Reagent

Trypan blue

Trypsin

Trypton

Tween-20

UltraPure ${ }^{\mathrm{TM}}$ Agarose

Xylol

Yeast extract
Carl Roth

Carl Roth

PerkinElmer, USA

Carl Roth

Merck

Carl Roth

Hartmann Analytic

Carl Roth

Carl Roth

Carl Roth

R\&D Systems ${ }^{\circledR}$

Carl Roth

Applied Biosystems, USA

AppliChem

TiterMax

Carl Roth

SIGMA-Aldrich ${ }^{\circledR}$

AppliChem

Invitrogen ${ }^{\mathrm{TM}}$

SIGMA-Aldrich ${ }^{\circledR}$

Biochrom

Carl Roth

Carl Roth

Invitrogen ${ }^{\mathrm{TM}}$

Carl Roth

Carl Roth

\subsubsection{Buffers, solutions and media}

Used buffers, solutions and media are listed in the corresponding method sections. If not specified otherwise, all buffers, solutions and media were stored at $4^{\circ} \mathrm{C}$. Buffers, solutions as well as self-made media were aqueous solutions and were autoclaved at $125^{\circ} \mathrm{C}$ for $30 \mathrm{~min}$ or filtrated using a $0.2 \mu \mathrm{m}$ sterile filter for sterilization.

The following common buffers and media were used:

PBS:

$$
\begin{array}{ll}
137 \mathrm{mM} & \mathrm{NaCl} \\
2.7 \mathrm{mM} & \mathrm{KCl} \\
10 \mu \mathrm{M} & \mathrm{Na}_{2} \mathrm{HPO}_{4} \\
2.0 \mathrm{mM} & \mathrm{KH}_{2} \mathrm{PO}_{4} \\
\text { dissolved in } & \mathrm{dH}_{2} \mathrm{O}, \mathrm{pH} 7.2
\end{array}
$$


TBS-T:

$$
\begin{array}{ll}
20 \mathrm{mM} & \text { Tris- } \mathrm{HCl} \\
137 \mathrm{mM} \quad \mathrm{NaCl} & \\
0.1 \%(\mathrm{v} / \mathrm{v}) & \text { Tween-20 } \\
\text { dissolved in } & \mathrm{dH}_{2} \mathrm{O}, \mathrm{pH} 7.6
\end{array}
$$

GIBCO $^{\circledast}$ DMEM+GlutaMax ${ }^{\mathrm{TM}}-$ I, Invitrogen ${ }^{\mathrm{TM}}$, UK

X-VIVO ${ }^{\text {TM }} 10$ LAK medium without Gentamicin and Phenol Red, Lonza Cologne GmbH

\subsubsection{Antibodies and recombinant proteins}

Antibodies were used according to manufacturer's instructions. Applied dilutions and concentrations of the antibodies and recombinant proteins are indicated in the respective method sections or figure legends.

\subsubsection{Primary and secondary antibodies for flow cytometry}

All antibodies listed in Table 2.4 are directed against human antigens and are conjugated to one of the following flourochromes: Fluorescein isothiocyanate (FITC), phycoerythrin (PE),

\begin{tabular}{|c|c|c|c|c|}
\hline Antigen & Isotype & Clone & Flourochrome & Supplier \\
\hline CD3 & "mouse $\lg G_{2 a}$ & MEM 57 & FITC & ImmunoTools \\
\hline CD4 & mouse $\lg G_{1}$ & RPA-T4 & $\mathrm{PE}$ & BioLegend \\
\hline CD8 & mouse $\lg G_{2 a}$ & $3 \mathrm{~B} 5$ & PE/Cy5 & Caltag Laboratories \\
\hline CD14 & mouse $\lg G_{2 a}$ & Tük4 & $\mathrm{PE}$ & Caltag Laboratories \\
\hline CD16 & mouse $\operatorname{lgG}_{1}$ & $3 G 8$ & PE/Cy5 & BioLegend \\
\hline CD19 & mouse $\operatorname{lgG}_{1}$ & HIB19 & $\mathrm{PE}$ & BioLegend \\
\hline CD56 & mouse $\operatorname{lgG}_{1}$ & HCD56 & $\mathrm{PE}$ & BioLegend \\
\hline CD69 & mouse $\lg G_{1}$ & FN50 & PE/Cy5 & BioLegend \\
\hline CD94 & mouse $\lg G_{1}$ & HP-3D9 & FITC & BD Biosciences \\
\hline CD107a (LAMP-1) & mouse $\lg G_{1}$ & $\mathrm{H} 4 \mathrm{~A} 3$ & FITC & BioLegend \\
\hline CD226 (DNAM-1) & mouse $\operatorname{lgG}_{1}$ & $11 \mathrm{~A} 8$ & FITC & BioLegend \\
\hline CD244 (2B4) & mouse $\lg G_{1}$ & C1.7 & $\mathrm{PE}$ & BioLegend \\
\hline CD314 (NKG2D) & mouse $\operatorname{lgG}_{1}$ & 149810 & $\mathrm{PE}$ & R\&D Systems \\
\hline CD335 (NKp46) & mouse $\lg G_{1}$ & $9 \mathrm{E} 2$ & $\mathrm{PE}$ & BioLegend \\
\hline CD336 (NKp44) & mouse $\operatorname{lgG}_{1}$ & $P-44-8$ & APC & BioLegend \\
\hline CD337 (NKp30) & mouse $\lg G_{1}$ & P30-15 & $\mathrm{PE}$ & BioLegend \\
\hline
\end{tabular}
phycoerythrin/cyanine 5 (PE/Cy5) or allophycocyanine (APC), respectively. Isotype controls (mouse $\operatorname{lgG}_{1}$ and $\lg G_{2 a}$ ) conjugated to the respective dye were purchased from ImmunoTools.

Table 2.4: Antibodies for flow cytometry 


$\begin{array}{lllll}\text { MICA } & \text { mouse } \operatorname{lgG} & \text { AMO1 } & - & \text { Bamomab GmbH } \\ \text { TCR } \gamma / \delta & \text { mouse } \operatorname{lgG}_{1} & \text { B1 } & \text { PE } & \text { BioLegend }\end{array}$

The following antibodies were used as secondary antibodies for flow cytometry:

Polyclonal goat anti-mouse IgG, FITC-conjugated, Jackson ImmunoResearch, Dianova GmbH

Polyclonal goat anti-human IgG, FITC-conjugated, Jackson ImmunoResearch, Dianova GmbH

\subsubsection{Primary and secondary antibodies for western blot analysis}

For western blot analysis all primary antibodies were diluted in TBS-T supplemented with 1\% BSA and $0.01 \% \mathrm{NaN}_{3}$. Secondary antibodies were diluted in TBS-T only.

\section{Primary antibodies:}

B-Actin: anti-B-Actin mouse $\operatorname{lgG}_{1}$ monoclonal antibody (mAb; AC-15), SIGMA-Aldrich ${ }^{\mathrm{TM}}$, USA

MICA: biotinylated anti-human MICA goat IgG polyclonal antibody, R\&D Systems

OVA: anti-chicken OVA ascites mouse IgG I $_{1}$ Ab (OVA-14), SIGMA-Aldrich ${ }^{\text {TM }}$, USA

Phospho-Akt: anti-phospho-Akt (Ser473) (D9E) XP' ${ }^{\mathrm{TM}}$ rabbit IgG mAb, Cell Signaling Technology ${ }^{\circledR}$, UK Phospho-PI3K: anti-phospho-PI3K p85 (Tyr458)/p55 (Tyr199) rabbit polyclonal antibody, Cell Signaling Technology ${ }^{\circledR}$, UK

Phospho-PLCY2: anti-phospho-PLCy2 (Tyr759) rabbit polyclonal antibody, Cell Signaling Technology ${ }^{\circledR}$, UK

Phospho-SLP-76: anti-phospho-SLP-76 (Tyr128) rabbit IgG polyclonal antibody, SIGMA-Aldrich ${ }^{\text {TM }}$, USA Phospho-Src: anti-phospho-Src family (Tyr419) rabbit IgG polyclonal antibody, Cell Signaling Technology ${ }^{\circledR}$, UK

Phospho-Syk: anti-phospho-Syk (Tyr352)/ZAP-70 (Tyr319) rabbit polyclonal antibody, Cell Signaling Technology ${ }^{\circledR}$, UK

Phospho-Tyr: anti-phospho-Tyr mouse mAb (4G10), Merck Millipore

Phospho-VAV1: anti-phospho-VAV1 (Tyr174) IgG rabbit polyclonal antibody, EPITOMICS ${ }^{\circledR}$, Abcam $^{\circledR}$, UK

\section{Secondary antibodies:}

Polyclonal goat anti-mouse IgG $(\mathrm{H}+\mathrm{L})$, horseradish peroxidase (HRP)-conjugated, ImmunoPure ${ }^{\circledR}$, USA Polyclonal goat anti-mouse $\lg _{2 b}(\mathrm{H}+\mathrm{L})$, HRP-conjugated, ImmunoPure ${ }^{\circledR}$, USA 
Polyclonal goat anti-rabbit IgG $(\mathrm{H}+\mathrm{L}), \mathrm{HRP}$-conjugated, ImmunoPure ${ }^{\circledR}, \mathrm{USA}$

Polyclonal rabbit anti-mouse IgG, HRP-conjugated, Dako GmbH

\subsubsection{Antibodies for enzyme-linked immunosorbent assay (ELISA)}

For the mouse immunoglobulin isotype $\mathrm{G}(\mathrm{m} / \mathrm{gG}$ ) screening ELISA (see 2.2.5.3.3) a goat anti-mouse IgG antibody (Dianova $\mathrm{GmbH}$ ) was used as capture antibody, while a goat anti-mouse antibody conjugated to HRP (Dianova $\mathrm{GmbH}$ ) was used as detection antibody. The antibodies applied for the IFN- $\gamma$ ELISA (see 2.2.5.3.1) and the sMICA ELISA (2.2.5.3.2) were components of commercial ELISA kits (see 2.1.12).

\subsubsection{Recombinant human proteins}

Table 2.5: Recombinant human proteins

\begin{tabular}{ll} 
Recombinant human protein & Supplier \\
\hline \hline IL-2 & R\&D Systems ${ }^{\circledR}$ \\
IL-12 HEK & ImmunoTools \\
IL-15 & ImmunoTools \\
IL-18 & MBL Co., LTD, Japan \\
NKG2D-Fc chimeric fusion protein (1299-NK) & R\&D Systems ${ }^{\circledR}$
\end{tabular}

\subsubsection{Enzymes}

Table 2.6: Enzymes

\begin{tabular}{|c|c|}
\hline Label & Supplier \\
\hline Calf intestine phosphatase & $\mathrm{NEB}^{\circledR}, \mathrm{USA}$ \\
\hline Collagenase, Type III, IV & SIGMA-Aldrich $^{\circledR}$ \\
\hline DNase I & Roche Diagnostics \\
\hline Endoglycosidase $\mathrm{H}_{\mathrm{f}}\left(\right.$ Endo $\left.\mathrm{H}_{\mathrm{f}}\right)$ & $\mathrm{NEB}^{\circledR}, \mathrm{USA}$ \\
\hline M-MLV Reverse Transcriptase & Promega \\
\hline Pfu Polymerase & Fermentas \\
\hline Phusion High-Fidelity DNA Polymerase & Finnzymes / NEB ${ }^{\circledR}$, USA \\
\hline Proteinase $\mathrm{K}$ & Merck \\
\hline Restriction enzymes & $\mathrm{NEB}^{\oplus}{ }^{\oplus}$, USA / Promega \\
\hline RNase A & Roche Diagnostics \\
\hline T4 DNA Ligase & Fermentas / NEB ${ }^{\circledast}$, USA \\
\hline Taq DNA Polymerase & GeneCraft $^{\circledR} / \mathrm{NEB}^{\circledR}$, USA \\
\hline
\end{tabular}




\subsubsection{Bacterial strains}

The chemo-competent Escherichia coli (E. coli) strain One Shot ${ }^{\circledR}$ Top10F' from Invitrogen $^{\text {TM }}$ was used for cloning procedures and plasmid preparations. This bacterial strain has the following genotype: $F^{\prime}$ lacla Tn10 (TetR) mcrA $\Delta$ (mrr-hsdRMS-mcrBC) Ф80lacZAM15 $\Delta$ lacX74 recA1 araD139 $\Delta$ (araleu)7697 galU galK rpsL endA1 nupG.

\subsubsection{Eukaryotic cell lines}

Table 2.7: Cell lines

\begin{tabular}{|c|c|c|}
\hline Label & Description & Source \\
\hline EPLC-272 & $\begin{array}{l}\text { human non-small cell lung carcinoma } \\
\text { cell line }\end{array}$ & $\begin{array}{l}\text { Prof. Gabriele Multhoff, Technical } \\
\text { University Munich (TMU) }\end{array}$ \\
\hline HEK293 & human embryonic kidney cells & Prof. Lutz Walter, DPZ, Göttingen \\
\hline K562 & human erythroleukemia cell line & $\begin{array}{l}\text { American Type Culture Collection }{ }^{\circledR} \\
\left(\text { ATCC }^{\circledR}\right), \text { USA }\end{array}$ \\
\hline Ltk $^{-}$ & mouse fibroblast tumor cell line & ATCC $^{\circledR}$, USA \\
\hline \multicolumn{3}{|l|}{ A375II } \\
\hline \multicolumn{3}{|l|}{$\mathrm{Ge}$} \\
\hline \multicolumn{3}{|l|}{ HT144 } \\
\hline \multicolumn{3}{|l|}{ Juso } \\
\hline \multicolumn{3}{|l|}{ Malme } \\
\hline Mel Ei & & Prof. Judith Johnson, Ludwig- \\
\hline Mel Ho & human melanoma cell lines & $\begin{array}{l}\text { Maximilians-University (LMU), Munich; } \\
\text { (Dressel et al., 1998) }\end{array}$ \\
\hline \multicolumn{3}{|r|}{ 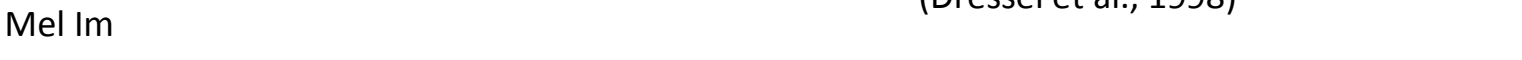 } \\
\hline \multicolumn{3}{|l|}{ Mel La } \\
\hline \multicolumn{3}{|l|}{ Mel Wei } \\
\hline \multicolumn{3}{|l|}{ Parl } \\
\hline \multicolumn{3}{|l|}{ Sk Mel-29 } \\
\hline \multicolumn{3}{|l|}{ WM266-4 } \\
\hline \multicolumn{3}{|l|}{ MCF-7 } \\
\hline MDA-MB & human breast cancer cell lines & Prof. Gabriele Multhoff, TMU \\
\hline \multicolumn{3}{|l|}{ T47D } \\
\hline NK-92 & $\begin{array}{l}\text { human non-Hodgkin's lymphoma NK cell } \\
\text { line }\end{array}$ & Dr. med. Justin Hasenkamp, UMG \\
\hline
\end{tabular}




\subsubsection{Laboratory animals}

The laboratory animals used during this project were bred in the central animal facility of the University Medical Center Göttingen. They were kept under specific pathogen-free conditions in individually ventilated cages and in a 12 h light-dark cycle. Female and male mice between 12 and 20 weeks of age were used for experiments. All animal experiments had been approved by the local government and were in accordance with institutional guidelines for the welfare of animals.

Table 2.8: Laboratory animals

\begin{tabular}{|c|c|c|c|}
\hline Label & Organism & Description & Source \\
\hline $\begin{array}{l}\text { SCID } \\
\text { (C.B-17/Ztm-scid) }\end{array}$ & mouse & $\begin{array}{l}\text { severe combined immunodeficiency } \\
\text { affecting } B \text { and T cells }\end{array}$ & $\begin{array}{l}\text { Prof. H.J. Hedrich, } \\
\text { Medical School } \\
\text { Hannover }\end{array}$ \\
\hline $\begin{array}{l}\text { SCID/beige } \\
\text { (C.B-17/lcrHsd-scid-bg) }\end{array}$ & mouse & $\begin{array}{l}\text { severe combined immunodeficiency } \\
\text { affecting B, T and NK cells }\end{array}$ & Harlan Winkelmann \\
\hline $\begin{array}{l}\operatorname{Rag} 2^{-/-} / \mathrm{c} \gamma \mathrm{c}^{-/-} \\
(\mathrm{C} 57 \mathrm{BL} / 6)\end{array}$ & mouse & $\begin{array}{l}\text { severe combined immunodeficiency } \\
\text { affecting } B, T \text { and NK cells }\end{array}$ & Taconic, USA \\
\hline
\end{tabular}

\subsubsection{Oligonucleotides}

All primers were synthesized by Metabion international AG or biomers.net $\mathrm{GmbH}$, respectively, as salt-free, lyophilized samples. Restriction site sequences were introduced close to the $5^{\prime}$ end of cloning primers to flank the resulting amplicons with new restriction sites, if required.

The qRT-PCR primers were designed using Integrated DNA Technologies ${ }^{\circledR}\left(\right.$ IDT $\left.^{\circledR}\right)$ 's PrimerQuest that incorporates Primer3 software developed by the Whitehead Institute for Biomedical Research. The primer specificity was verified with the nucleotide BLAST from National Center for Biotechnology Information (NCBI). All qRT-PCR primers were designed to span exon-exon junctions, if feasible. In case of targets with two isoforms the primers were designed to target both transcripts. Primer sequences are shown in Table 2.9-2.12.

Table 2.9: $\quad$ Primer pairs for qRT-PCR

\begin{tabular}{lll} 
Label & Sequence $\left(\mathbf{5}^{\prime} \boldsymbol{\rightarrow} \mathbf{3} \mathbf{\prime}\right)$ & RefSeq \\
\hline \hline GAPDH_F & TGTGTCCGTCGTGGATCTGA & RTPrimerDB ID : 7880 \\
GAPDH_R & TTGCTGTTGAAGTCGCAGGAG & \\
\hline HPRT1q_F & GTCCTGTGGCCATCTGCCTA & NM_013556.2 \\
HPRT1q_R & GGGACGCAGCAACTGACATT & \\
\hline
\end{tabular}




\begin{tabular}{lll} 
MICA_F & ACTTGACAGGGAACGGAAAGGA & AB015600 \\
MICA_R & CCATCGTAGTAGAAATGCTGGGA & \\
\hline MICAq_F & CTGATGGGAATGGAACCTACCAGA & NM_001177519.1 \\
MICAq_R & CAGCAGCAACAGCAGAAACATGGA &
\end{tabular}

Table 2.10: Primers for cloning

\begin{tabular}{ll} 
Label & Sequence (5' $\rightarrow$ 3') \\
\hline \hline MICA_HindIII_F & TAAAGCTTATACTGCTTGAGCCGCTGAG \\
MICA_BamHI_R & ATGGATCCAGGAAAGTGCTCGTGAGATCC \\
\hline MICA_MSCV_F & TCTCGAGATGGGGCTGGGCCCGGTCTTC \\
MICA_MSCV_R & CGAATTCCTAGGCGCCCTCAGTGGAGCCAGTG \\
\hline MICA_mut24_SNP_F & AGGGTTTCTCGCTGAGGTAC \\
MICA_mut24_SNP_R & GTACCTCAGCGAGAAACCCT \\
\hline MICA_mut129_SNP_F & AATGGACAGTGCCCCAG \\
MICA_mut129_SNP_R & CTGGGGCACTGTCCATT \\
\hline MICA_mut360_SNP_F & TGAGGGCGCCTAGACTC \\
MICA_mut360_SNP_R & GAGTCTAGGCGCCCTCA \\
\hline MICA_pcDNA_KpnI_F & TGGTACCATGGGGCTGGGCCCGGTCTTCCTGC \\
MICA_pcDNA_BamHI_R & CGGATCCTGAAGCACCAGCACTTTCCCAGA \\
\hline MICA_pFUSE_Agel_F & CACCGGTATGGGGCTGGGCCCGGTCTTC \\
MICA_pFUSE_Xhol_R & TCTCGAGCGCTGAAGCACCAGCACTTTCCCA \\
\hline mIgG 2 2_pCDNA_BamHI_F & TGGATCCTCCCAGAGGGCCCACAATCAA \\
mIgG_a_pCDNA_EcoRI_R & CGAATTCTCATTTACCCGGAGTCCG \\
\hline OVA-Fc_KpnI_F & CAGGTACCATGGGCTCCATCGGCGCAGCAA \\
OVA-Fc_BamHI_R & TGAGGATCCATAGGGGAAACACATCTGCCAAAG
\end{tabular}

Table 2.11: Primers for sequencing

\begin{tabular}{ll} 
Label & Sequence $\left(\mathbf{5}^{\prime} \boldsymbol{\rightarrow} \mathbf{3} \mathbf{)}\right.$ \\
\hline \hline Seq_pCMV6_F & TGCGGGGTCTATTGGGAACCAAGCT \\
\hline Seq_pCMV6-AC_F & GAATCACAGCACTCACCCTG \\
\hline Seq_SNP454_MICA_F & CCATGAAGACAACAGCACCA \\
Seq_SNP454_MICA_R & CAGGACTACGCCGGATTTTA \\
\hline T7_Seq_F & TAATACGACTCACTATAGGG \\
\hline VP1.5_F & GGACTTTCCAAAATGTCG \\
\hline VP_pFUSE_F & TGCTTGCTCAACTCTACGTC \\
VP_pFUSE_R & GGAAGATGAAGACGGATGGTC
\end{tabular}


Table 2.12: Primers for genotyping

\begin{tabular}{ll} 
Label & Sequence $\left(\mathbf{5}^{\prime} \boldsymbol{\rightarrow}\right.$ 3') \\
\hline \hline MICA-129_Ex3_F & GCTCTTCCTCTCCCAAAACCT \\
\hline MICA-129_Ex3_R & CGTTCATGGCCAAGGTCTGA \\
\hline Polymorph_129_Met_F & CTGGAGACTGAGGAATGGACAA \\
\hline Polymorph_129_Val_F & CTGGAGACTGAGGAATGGACAG \\
\hline Polymorph_129_R & CTCAAAGATACCCCATCCTGAC
\end{tabular}

Primers for SNP genotyping were purified by High-performance liquid chromatography (HPLC).

\subsubsection{Vectors and constructs}

Common vectors and constructs generated therefrom are listed in Table 2.13 and 2.14.

Table 2.13: Vectors

\begin{tabular}{|c|c|}
\hline Label & Supplier \\
\hline pcDNA3.1 $1^{\mathrm{TM}} / m y c-$ His $\mathrm{A}(+)$ & Invitrogen ${ }^{\mathrm{TM}}$ \\
\hline pCMV6-AC & OriGene, USA \\
\hline PEGFP-1 & Clontech \\
\hline pFUSE-mlgG ${ }_{2 a}-F c 1$ & InvivoGen, France \\
\hline
\end{tabular}

Table 2.14: Constructs

\begin{tabular}{ll} 
Label & Application \\
\hline \hline pcDNA3.1-MICA-129Met-mlgG $2 \mathrm{a}-\mathrm{Fc}$ & \\
pcDNA3.1-MICA-129Val-mlgG & \\
pcDNA3.1-OVA-mlgG & \\
\hline pCMV $-\mathrm{Fc}$ & Transfection of HEK293 cells \\
pCMV6-AC-MICA-129Met &
\end{tabular}

\subsubsection{Commercial kits}

Table 2.15: Commercial kits

\begin{tabular}{ll} 
Label & Supplier \\
\hline \hline ABsolute $^{\mathrm{TM}}$ Blue QPCR SYBR \\
\hline EndoFree Plasmid Maxi Kit $^{\circledR}$ Treen Low ROX Mix & Thermo Fisher Scientific \\
\hline $\begin{array}{l}\text { CloneJET } \\
\text { GeneJET PCR Cloning Kit }\end{array}$ & QIAGEN \\
\hline
\end{tabular}


Human IFN- $\gamma$ ELISA

Human MICA DuoSet ELISA

Human NK Cell Isolation Kit

Power SYBR ${ }^{\circledR}$ Green PCR Master Mix

PureYield ${ }^{\mathrm{TM}}$ Plasmid Midiprep System

Wizard $^{\circledR}$ SV Gel and PCR Clean-Up System

TaqMan ${ }^{\circledast}$ MICA-129 Genotyping Assay (Assays-by-

Design $^{\text {SM }}$ Service for SNP Genotyping Assays)

TransIT $^{\circledR}$-293 Transfection Reagent

Zymoclean $^{\text {TM }}$ Gel DNA Recovery Kit
ImmunoTools

R\&D Systems ${ }^{\circledR}$

MACS Miltenyi Biotec

Applied Biosystems, USA

Promega

Applied Biosystems, USA

Mirus Bio LLC, USA

Zymo Research

\subsubsection{Software and databases}

\author{
7500 System SDS software \\ 7900HT System SDS software \\ Bio Edit \\ CellQuest Pro \\ Cyflogic \\ Endnote X1.0.1 \\ FlowJo \\ Gel GDS software \\ GelPro analyzer \\ GENtle \\ ImageG \\ MicroBeta Workstation \\ NCBI database \\ NEB-Cutter \\ Oligo Analyzer \\ Primer Quest \\ qPCR primer database \\ Scrubber 2.0 \\ WinStat \\ Works 2007
}

Applied Biosystems, USA

Applied Biosystems, USA

Ibis Biosciences

BD Biosciences

Perttu Terho \& CyFlo Ltd, Finnland

Thomson Reuters

Tree Star, Inc., USA

Intas Science Imaging

Media Cybernetics, USA

Magnus Manske - University of Cologne

National Institutes of Health (NIH), USA

PerkinElmer, USA

National Center for Biotechnology Information (NCBI), USA

$\mathrm{NEB}^{\circledR}$, USA

Integrated DNA Technologies ${ }^{\circledR}\left(\right.$ IDT $\left.^{\circledR}\right)$, Belgium

IDT $^{\circledR}$, Belgium

RTprimerDB.org

BioLogic Software, Campbell, Australia

R. Fitch Software

Microsoft 


\subsection{Methods}

\subsubsection{Microbiological methods}

\subsubsection{Transformation of chemo-competent E. coli}

Circular plasmid DNA was introduced into the chemo-competent $E$. coli strain Top10F' using the heat shock method. Therefore, bacteria were thawed on ice, 50-100 ng plasmid DNA or $10 \mu$ l of a ligation reaction were added and mixed gently. After 30 min incubation on ice, the mixture was heat-shocked at $42^{\circ} \mathrm{C}$ for $90 \mathrm{sec}$, briefly returned to ice and cells were then resuspended in $400 \mu \mathrm{l} \mathrm{SOC}$ medium. For cell recovering the transformation mixture was incubated in a thermoblock at $37^{\circ} \mathrm{C}$ and $500 \mathrm{rpm}$ for 1 h. Subsequently, the mixture was plated on LB agar plates supplemented with an appropriate antibiotic, according to the resistance mediated by the incorporated plasmid after successful transformation, and cultured at $37^{\circ} \mathrm{C}$ overnight.

SOC medium:

LB medium:

LB agar plates:

Antibiotic concentrations:

$\begin{array}{ll}2 \%(\mathrm{w} / \mathrm{v}) & \text { Tryptone } \\ 0.5 \%(\mathrm{w} / \mathrm{v}) & \text { Yeast extract } \\ 10 \mathrm{mM} & \mathrm{MgCl}_{2} \\ 10 \mathrm{mM} & \mathrm{MgSO}_{4} \\ 10 \mathrm{mM} & \mathrm{NaCl} \\ 2.5 \mathrm{mM} & \mathrm{KCl} \\ 20 \mathrm{mM} & \mathrm{Glucose} \\ \text { dissolved in } & \mathrm{dH}_{2} \mathrm{O}\end{array}$

$0.5 \%(\mathrm{w} / \mathrm{v}) \quad$ Yeast extract

$0.5 \%(\mathrm{w} / \mathrm{v}) \mathrm{NaCl}$

$1 \%(\mathrm{w} / \mathrm{v}) \quad$ Tryptone

dissolved in $\mathrm{dH}_{2} \mathrm{O}$

$1.5 \%(\mathrm{w} / \mathrm{v})$ agar in LB medium

Ampicillin: $100 \mu \mathrm{g} / \mathrm{ml}$ in $\mathrm{dH}_{2} \mathrm{O}$

Kanamycin: $50 \mu \mathrm{g} / \mathrm{ml}$ in $\mathrm{dH}_{2} \mathrm{O}$

\subsubsection{Culture and storage of chemo-competent E. coli}

Chemo-competent E. coli Top10F' cells were cultured under aerobic conditions in an incubator shaker at $37^{\circ} \mathrm{C}$ and $200 \mathrm{rpm}$ overnight. LB medium containing the corresponding antibiotic was used 
for the cultures. For small volumes $(3 \mathrm{ml}) 13 \mathrm{ml}$ plastic tubes or for large volumes $(100 \mathrm{ml})$ Erlenmeyer flasks were used, respectively. For long-term storage, $800 \mu \mathrm{l}$ of an E.coli overnight culture was vigorously mixed with $200 \mu \mathrm{l} 100 \%$ glycerol and stored at $-80^{\circ} \mathrm{C}$.

\subsubsection{Biomolecular methods}

\subsubsection{Purification of nucleic acids}

\subsection{Extraction of nucleic acids from agarose gels}

DNA fragments were extracted and purified from agarose gels or directly from PCR reactions using the Zymoclean ${ }^{\mathrm{TM}}$ Gel DNA Recovery Kit or the Promega Wizard ${ }^{\circledR}$ SV Gel and PCR Clean-Up System according to manufacturer's instructions. DNA was eluted from the column with 10-50 $\mu$ l nucleasefree $\mathrm{dH}_{2} \mathrm{O}$.

\subsection{Alcohol precipitation of nucleic acids}

Nucleic acids were precipitated from aqueous solution by adding $1 / 10$ volume of $3 \mathrm{M}$ sodium acetate $(\mathrm{pH} 4.8)$ and one volume isopropanol or 2.5 volumes $100 \%$ ethanol $\left(-20^{\circ} \mathrm{C}\right)$, respectively. To avoid coprecipitation of short oligonucleotides $1 / 3$ volume of $7.5 \mathrm{M}$ ammonium acetate was alternatively used instead of sodium acetate. Samples were centrifuged at $15,000 \mathrm{rpm}$ at $4^{\circ} \mathrm{C}$ for $30 \mathrm{~min}$. The supernatant was discarded, the resulting DNA pellet washed with $70 \%$ ethanol and then air-dried before being dissolved in an appropriate volume $\mathrm{dH}_{2} \mathrm{O}$ and stored at $-20^{\circ} \mathrm{C}$.

\subsection{Phenol-chloroform extraction of nucleic acids}

Protein contaminations were removed from nucleic acid samples by adding an equal volume of phenol-chloroform-isoamyl alcohol (25:24:1) and thoroughly mixed. For phase separation, the mixture was centrifuged and the DNA-containing aqueous phase was transferred into a new reaction tube. This procedure was repeated once with chloroform only. Subsequently, nucleic acids were precipitated using the alcohol precipitation method (see 2.2.2.1.2). 


\subsubsection{Isolation of nucleic acids}

\subsection{Plasmid DNA preparation}

LB medium containing an appropriate antibiotic was inoculated with a single bacterial colony from a LB agar plate or some bacterial suspension of a frozen glycerol stock and incubated at $37^{\circ} \mathrm{C}$ and 200 rpm overnight (see 2.2.1.2). Plasmid DNA was isolated either from $1.5 \mathrm{ml}$ overnight culture for plasmid mini preparation or from $100 \mathrm{ml}$ for plasmid midi or maxi preparation, respectively, according to manufacturer's instructions using kits listed in Table 2.15. For isolation of nonpreparative plasmid DNA (e.g., for test restriction endonuclease digestion), E. coli were treated with buffers for alkaline lysis according to standard protocol (Birnboim \& Doly, 1979). Subsequently, DNA was precipitated by addition of $80 \%$ isopropanol to the mixture, washed with $70 \%$ ethanol and dissolved in $\mathrm{dH}_{2} \mathrm{O}$ (see 2.2.2.1.2).

\subsection{Genomic DNA preparation}

One million to $5 \times 10^{6}$ cells were harvested, washed with PBS and resuspended in $500 \mu$ l lysis buffer. The suspension was incubated in a thermomixer at $50^{\circ} \mathrm{C}$ and $500 \mathrm{rpm}$ overnight. To remove proteins and other contaminants and for subsequent precipitation of the genomic DNA, the cell lysis was followed by a phenol-chloroform extraction (see 2.2.2.1.3) and an alcohol precipitation (2.2.2.1.2) using 2 volumes $100 \%$ ethanol and 1/10 volume $5 \mathrm{M}$ lithium chloride (LiCl). Genomic DNA was dissolved in $\mathrm{dH}_{2} \mathrm{O}$ or $8 \mathrm{mM} \mathrm{NaOH}$ and stored at $4^{\circ} \mathrm{C}$.

$\begin{array}{lll}\text { Lysis buffer: } & 100 \mathrm{mM} & \mathrm{NaCl} \\ & 50 \mathrm{mM} & \text { EDTA, pH 8.0 } \\ 10 \mathrm{mM} & \text { Tris-HCl, pH 8.0 } \\ 0.5 \% & \text { Sodium dodecyl sulfate (SDS) } \\ 0.1 \mathrm{mg} / \mathrm{ml} & \text { Proteinase } \mathrm{K} \\ 20 \mu \mathrm{ml} / & \text { RNase A } \\ \text { dissolved in } & \mathrm{dH}_{2} \mathrm{O}\end{array}$

\subsection{RNA preparation}

The TRIzol ${ }^{\circledR}$ reagent was used to isolate RNA from $10^{6}$ to $5 \times 10^{6}$ cells or $100 \mathrm{mg}$ tissue according to the manufacturer's protocol. In brief, after tissue homogenization and cell harvest, $1 \mathrm{ml}$ TRIzol ${ }^{\circledR}$ reagent was added to lyse the cells. For phase separation, $200 \mu l$ chloroform were used. 
Subsequently, the colorless upper aqueous phase, containing the RNA, was transferred into a new reaction tube and $500 \mu \mathrm{l} 100 \%$ ethanol were added to precipitate RNA. Followed by a washing step with $1 \mathrm{ml}$ 75\% ethanol, the resulting RNA pellet was air-dried, resuspended in $50 \mu \mathrm{RNase-free} \mathrm{dH}_{2} \mathrm{O}$ and stored at $-80^{\circ} \mathrm{C}$. Quality of RNA was assured by visualization of the integrity of $18 \mathrm{~S}$ and $28 \mathrm{~S}$ RNA loaded on a $1 \%$ agarose gel (see 2.2.2.5). All RNA samples were quantified with a spectrophotometer at a wavelength of $260 \mathrm{~nm}$ (see 2.2.2.6).

\subsubsection{Amplification of nucleic acids}

\subsection{Polymerase chain reaction (PCR)}

The PCR is a technique used for DNA analysis and molecular cloning and is based on the in vitro amplification of a specific DNA segment (Mullis et al., 1986). The basic reaction includes three repetitive temperature steps allowing denaturation of double-stranded DNA (dsDNA), primer annealing to the single-stranded DNA (ssDNA) template and elongation by a DNA polymerase.

For analytical proposes, Taq DNA polymerase was used and the reaction was set up as follows:

$\begin{array}{ll}2.5 \mu \mathrm{l} & 10 \times \text { Taq PCR buffer } \\ 0.5 \mu \mathrm{l} & \text { dNTP mix (10 mM of each dNTP: dATP, dCTP, dGTP, dTTP) } \\ 5 \mathrm{pmol} / \mu \mathrm{l} & \text { sense primer } \\ 5 \mathrm{pmol} / \mu \mathrm{l} & \text { anti-sense primer } \\ 100 \mathrm{ng} & \text { template DNA } \\ 5 \mathrm{Units}(\mathrm{U}) & \text { Taq DNA polymerase } \\ \text { add to } 25 \mu \mathrm{l} & \mathrm{dH}_{2} \mathrm{O}\end{array}$

For preparative proposes such as molecular cloning and site-directed mutagenesis, PCR reactions were performed using Phusion High-Fidelity DNA polymerase, since this enzyme possess $3^{\prime} \rightarrow 5^{\prime}$ proofreading activity. To introduce point mutations in DNA constructs, the respective construct was subjected to PCR using two oligonucleotide primers containing the desired mutation in the middle. The PCR reaction was then incubated with $1 \mu$ I Diplococcus pneumonia I (DpnI) endonuclease at $37^{\circ} \mathrm{C}$ for $1 \mathrm{~h}$ to digest the parental, methylated DNA template plasmid. The following PCR setup was used:

$\begin{array}{ll}10 \mu \mathrm{l} & 5 \times \text { Phusion PCR buffer } \\ 1 \mu \mathrm{l} & \text { dNTP mix (10 mM each) } \\ 10 \mathrm{pmol} / \mu \mathrm{l} & \text { sense primer } \\ 10 \mathrm{pmol} / \mu \mathrm{l} & \text { anti-sense primer } \\ 100 \mathrm{ng} & \text { template DNA } \\ 2 \mathrm{U} & \text { Phusion DNA polymerase }\end{array}$


add to $50 \mu \mathrm{l} \quad \mathrm{dH}_{2} \mathrm{O}$

The PCR cycler program was adapted with respect to temperature and time for denaturation, annealing and elongation steps. Denaturation as well as elongation temperatures and times were associated with the DNA polymerase specifications and were set according to manufacturer's instructions. Annealing temperatures were set according to the specific melting temperature of the primers which were used. An exemplary PCR program for the amplification of the MICA gene sequence (1152 bp) using the pCMV6-AC-MICA-129Met/Val construct as template and the Phusion DNA polymerase is indicated in the Table 2.16.

Table 2.16: Exemplary PCR program

\begin{tabular}{lcl} 
Step & Temperature & Time \\
\hline \hline Initial denaturation & $98^{\circ} \mathrm{C}$ & $3 \mathrm{~min}$ \\
\hline Denaturation* & $98^{\circ} \mathrm{C}$ & $30 \mathrm{sec}$ \\
\hline Primer annealing* & $65^{\circ} \mathrm{C}$ & $25 \mathrm{sec}$ \\
\hline Elongation* & $72^{\circ} \mathrm{C}$ & $30 \mathrm{seC}$ \\
\hline Final elongation & $72^{\circ} \mathrm{C}$ & $5 \mathrm{~min}$ \\
\hline
\end{tabular}

$*$ in 30 cycles

\subsection{CDNA synthesis}

For qRT-PCR, it is necessary to transcribe RNA into CDNA. For this purpose, random hexamers, which are short oligodeoxyribonucleotides of random sequence $\left[\mathrm{d}(\mathrm{N})_{6}\right]$ that anneal to random complementary sites on the target RNA, and M-MLV reverse transcriptase were used.

Two $\mu \mathrm{g}$ RNA were mixed with $2 \mu \mathrm{l}$ random hexamer primers and filled up with $\mathrm{dH}_{2} \mathrm{O}$ to a final volume of $15 \mu \mathrm{l}$. This mixture was incubated at $70^{\circ} \mathrm{C}$ for $10 \mathrm{~min}$ to break up secondary structures of the RNA. The sample was chilled down on ice to prevent reforming of these structures. Subsequently, the following master mix was added to the sample:

$$
\begin{array}{ll}
5 \mu \mathrm{l} & 5 \times \text { reverse transcriptase buffer } \\
2 \mu \mathrm{l} & \text { dNTP } \operatorname{mix}(10 \mathrm{mM}) \\
1 \mu \mathrm{l} & \text { DTT }(0.1 \mathrm{M}) \\
1 \mu \mathrm{l} & \text { RNasin plus RNase inhibitor }(40 \mathrm{U} / \mu \mathrm{l}) \\
1 \mu \mathrm{l} & \text { M-MLV reverse transcriptase }(200 \mathrm{U} / \mu \mathrm{l})
\end{array}
$$

The reverse transcription reaction was incubated at $37^{\circ} \mathrm{C}$ for $1 \mathrm{~h}$ for transcription of RNA into cDNA and afterwards stored at $-20^{\circ} \mathrm{C}$. 


\subsection{Quantitative real-time PCR ( $q R T-P C R)$}

Quantitative PCR in real-time was performed to determine the relative amount of specific mRNA transcripts of a gene of interest using the ABI 7500 Real-Time PCR system and the ABsolute ${ }^{\mathrm{TM}}$ Blue QPCR SYBR ${ }^{\circledR}$ green mix, which comprises polymerase buffer, dNTPs, a hot start polymerase and SYBR green dye to amplify and detect DNA. The cDNA was diluted 1:40 with $\mathrm{dH}_{2} \mathrm{O}$ and the reaction was set up as follows:

$\begin{array}{ll}10 \mu \mathrm{l} & \text { ABsolute }^{\mathrm{TM}} \text { Blue QPCR SYBR } \\ & { }^{\circledR} \text { green mix } \\ 5 \mathrm{pmol} / \mu \mathrm{l} & \text { sense primer } \\ 1 \mu \mathrm{pmol} / \mu \mathrm{l} & \text { anti-sense primer } \\ \text { add to } 20 \mu \mathrm{l} & \text { template cDNA } \\ \mathrm{dH}_{2} \mathrm{O}\end{array}$

The following qRT-PCR cycler program was used:

Table 2.17: qRT-PCR program

\begin{tabular}{lcc} 
Step & Temperature & Time \\
\hline \hline Enzyme activation & $50^{\circ} \mathrm{C}$ & $2 \mathrm{~min}$ \\
\hline Initial denaturation & $95^{\circ} \mathrm{C}$ & $10 \mathrm{~min}$ \\
\hline Denaturation* & $95^{\circ} \mathrm{C}$ & $15 \mathrm{seC}$ \\
\hline Annealing/elongation* & $60^{\circ} \mathrm{C}$ & $1 \mathrm{~min}$ \\
\hline Dissociation stage & $95^{\circ} \mathrm{C}$ & $15 \mathrm{seC}$ \\
\hline & $60^{\circ} \mathrm{C}$ & $20 \mathrm{seC}$ \\
\hline Recording of the & stepwise rising of the & $20 \mathrm{seC}$ \\
dissociation curve & temperature to $95^{\circ} \mathrm{C}$ & \\
\hline
\end{tabular}

$*$ in 40 cycles

The stepwise increase in temperature during the dissociation stage was used to verify product specificity. Since SYBR green dye intercalates non-specifically into DNA, unintended products, such as primer dimers, contaminations and mispriming artifacts, could cause a false positive fluorescence signals. Since the melting temperatures of intended products were known, their specificity was assured by comparison with the temperature peak of the according dissociation curve. For cycle threshold ( $\mathrm{Ct}$ ) values above 30 , no qRT-PCR data were calculated, since this late amplification was considered to be unspecific. All genes of interest were analyzed in triplicates to reduce expression variation. cDNAs obtained from human and mouse tumor cell lines were analyzed with specific MICA primers and primers for the housekeeping gene Hprt or Gapdh, respectively (see Table 2.9). After each PCR cycle, the amount of dsDNA was measured and calculated by the AB 7500 
System SDS Software. Ct values of the target genes were subtracted by the $\mathrm{Ct}$ values of the housekeeping gene $(\Delta \mathrm{Ct})$. The quantity was calculated as $2^{-\Delta \Delta C t}$ relative to the control (Livak and Schmittgen, 2001).

\subsection{TaqMan MICA-129 genotyping assay}

Genomic DNA of all patient and donor (P/D) pairs of the allogeneic hematopoietic stem cell transplantation (HSCT) cohort transplanted in the Department of Hematology and Medical Oncology at the University Medical Center Göttingen was isolated from EDTA-treated peripheral blood samples. For discrimination of MICA-129 genotypes of each studied pair of alleles, a SNP genotyping TaqMan assay on demand from Applied Biosystems was used. The 40x SNP genotyping assay contains unlabeled sequence-specific PCR primers to amplify the polymorphic MICA sequence of interest in the exon 3 and two MICA-129 allele-specific TaqMan minor groove binder (MGB) probes: One probe is labeled with $\mathrm{VIC}^{\circledR}$ dye detecting the MICA-129Met allele sequence and the other probe is labeled with FAM $^{\mathrm{TM}}$ dye detecting the MICA-129Val allele. The sequences of the forward and reverse primer are shown above (see Table 2.12: MICA-129_Ex3_F and MICA-129_Ex3_R) and of the two probes were as follows: MICA-129_Ex3_Met, VIC-5'-AATGGACAATGCCCC; MICA-129_Ex3_Val, FAM-5'-AATGGACAGTGCCCC. The assay enables scoring of both alleles in a single well. It was performed in 384-well plates and is optimized to work with genomic DNA. The pipetting scheme of the reaction components for a single $5 \mu$ reaction is shown below:

$\begin{array}{ll}2.5 \mu \mathrm{l} & \text { 2x TaqMan Universal PCR Master Mix } \\ 0.125 \mu \mathrm{l} & \text { 40x PCR primer and TaqMan MGB probe mix } \\ 2.375 \mu \mathrm{l} & \text { genomic DNA (10 ng) diluted in } \mathrm{dH}_{2} \mathrm{O} \\ \text { add to } 5 \mu \mathrm{l} & \mathrm{dH}_{2} \mathrm{O}\end{array}$

The assay utilizes the thermal cycling parameters described in Table 2.18:

Table 2.18.: Thermal cycler conditions for TaqMan genotyping assay

\begin{tabular}{lcc} 
Step & Temperature & Time \\
\hline \hline Initial steps & $95^{\circ} \mathrm{C}$ & $10 \mathrm{~min}$ \\
\hline Denaturation* & $92^{\circ} \mathrm{C}$ & $15 \mathrm{sec}$ \\
\hline Annealing/elongation* & $60^{\circ} \mathrm{C}$ & $1 \mathrm{~min}$ \\
\hline
\end{tabular}

$*$ in 40 cycles 
The two dye-labeled MGB probes, specific for either the MICA-129Met or MICA-129Val allele, provide a fluorescence readout of the amplification of each allele. For analysis, the $A B 7900 \mathrm{HT}$ System SDS Software was used.

In parallel to MICA-129 genotyping of the P/D pair genomic DNAs, also control samples were genotyped by the TaqMan assay. These were determined to be heterozygous or homozygous for the MICA-129 alleles as checked before by nucleotide sequencing.

\subsubsection{Molecular cloning}

\subsection{Restriction endonuclease digestion of nucleic acids}

For site-directed cleavage and generation of 3'-hydroxyl and 5'-phosphate termini, substrate DNA was incubated with type II restriction endonucleases in a thermoblock at $37^{\circ} \mathrm{C}$ and $300 \mathrm{rpm}$ for at least $1 \mathrm{~h}$ up to $16 \mathrm{~h}$ (overnight digestion) depending on the applied enzyme and the DNA amount. Endonucleases recognize restriction sites of 4-8 nucleotides which are usually undivided and palindromic. Nucleic acids were digested in a reaction volume of at least $20 \mu \mathrm{l}$ up to a maximum of $100 \mu \mathrm{l}$ according to the specific reaction conditions of the different restriction enzymes to assure complete digestion, which was subsequently probed by agarose gel electrophoresis (see 2.2.2.5).

\subsection{Dephosphorylation of vector DNA}

To prevent religation of vector DNA, especially in case of blunt ended DNA fragments, which were cut with only one restriction endonuclease, phosphate residues were removed using calf intestine phosphatase (CIP). Usually, $1 \mu \mathrm{l}$ of CIP enzyme (10 U) was added directly to the restriction mixture and incubated at $37^{\circ} \mathrm{C}$ for $30 \mathrm{~min}$.

\subsection{Ligation of DNA fragments}

The T4 DNA ligase was used for the formation of phosphodiester bonds between linearized vector DNA and insert DNA fragments. A $20 \mu \mathrm{l}$ reaction with $1 \mu \mathrm{l}(5 \mathrm{U})$ of the ligase in an ATP-containing T4 DNA Ligase buffer was prepared and incubated at room temperature (RT) for $1 \mathrm{~h}$ or at $16^{\circ} \mathrm{C}$ overnight. The corresponding amounts of insert DNA and vector DNA were calculated according to the formula shown below. $10 \mu \mathrm{l}$ of the ligation mixture were subsequently used for transformation of chemo-competent $E$. coli cells (see 2.2.1.1). 
amount of insert $(\mathrm{ng})=\frac{10 \mathrm{x} \text { amount of vector }(\mathrm{ng}) \mathrm{x} \text { insert lenght }(\mathrm{bp})}{\text { vector length }(\mathrm{bp})}$

\subsection{TA cloning}

The Invitrogen TA cloning kit was used for direct ligation of DNA fragments amplified with Taq polymerase. DNA amounts and reaction volumes were set up according to manufacturer's instructions. For the direct ligation of blunt ended DNA fragments which were produced, e.g., by the Phusion DNA polymerase or by specific restriction endonucleases, the Fermentas CloneJET PCR cloning kit was used according to the manufacturer's protocol.

\subsubsection{Agarose gel electrophoresis of nucleic acids}

Agarose gel electrophoresis was performed for identification and separation of DNA fragments using the Perfect Blue ${ }^{\mathrm{TM}}$ gel system. The agarose concentration varied between $0.7 \%$ up to $2 \%(\mathrm{w} / \mathrm{v})$ according to the size of DNA fragments. TAE buffer was used as running buffer and for preparation of agarose solutions, which were dissolved in the microwave at $300 \mathrm{~W}$ for $5 \mathrm{~min}$. Ethidium bromide, which intercalates into the DNA double helix, was added to a final concentration of $0.1 \%(\mathrm{v} / \mathrm{v})$ to identify DNA fragments when exposed to UV light. DNA samples were mixed with 6x DNA loading dye to facilitate the loading procedure. An electric field of $90-120 \mathrm{~V}$ and $220 \mathrm{~mA}$ was applied for 30-60 min according to the DNA fragment size. In addition, the DNA molecular weight standard GeneRuler $1 \mathrm{~kb}$ DNA ladder was loaded on the gel for determination of DNA size. The running time for RNA samples should not exceed 15 min to avoid RNA degradation.

\begin{tabular}{|c|c|c|c|c|c|}
\hline \multirow[t]{2}{*}{ 6x DNA loading dye: } & $34 \%(w / v)$ & Sucrose & or & $10 \mathrm{mM}$ & Tris- $\mathrm{HCl}, \mathrm{pH} 7.6$ \\
\hline & \multicolumn{3}{|c|}{$0.02 \%(w / v)$ Cresol red dye } & $0.03 \%$ & Bromophenol blue \\
\hline
\end{tabular}

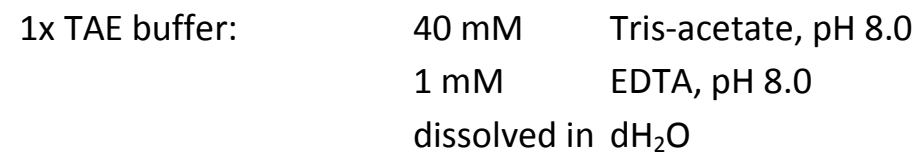




\subsubsection{Photometric determination of nucleic acid concentration}

Concentration of dsDNA and RNA was determined with an Eppendorf BioPhotometer in UVettes or with a NanoDrop ${ }^{\mathrm{TM}}$ ND-1000 spectrophotometer and calculated using the following equations:

$1 \mathrm{~A}_{260}$ Unit of dsDNA $=50 \mu \mathrm{g} \mathrm{DNA} / \mathrm{ml}$ diluent or $1 \mathrm{~A}_{260}$ Unit of RNA $=40 \mu \mathrm{g} \mathrm{DNA} / \mathrm{ml}$ diluent

The purity of DNA or RNA can be estimated by the value for pure DNA of $A_{260} / A_{280} \geq 1.8$ or for pure RNA of $A_{260} / A_{280} \geq 2.0$.

\subsubsection{Biochemical methods}

\subsubsection{Production and purification of recombinant Fc-fusion proteins}

For generation of Fc-fusion proteins, expressing the $\mathrm{Fc}$ region ( $\mathrm{CH} 2$ and $\mathrm{CH} 3$ domains) of the murine $\operatorname{lgG}_{2 a}$ heavy chain and the hinge region, which is fused to the protein of interest, $10^{7}$ HEK293 cells were stably transfected (see 2.2.4.7) with $50 \mu \mathrm{g}$ Pvul-linearized and purified DNA of the MICA129Met-Fc, MICA-129Val-Fc or OVA-Fc expression construct, respectively. After selection with geneticin $(0.5 \mathrm{mg} / \mathrm{ml} \mathrm{G} 418)$, MICA-129-Fc and OVA-Fc production was analyzed using a mlgG screening ELISA (see 2.2.5.3.3), since the fusion proteins are secreted as MICA or OVA homodimers. For production of Fc-fusion protein-containing supernatants, the corresponding HEK293 transfectants were cultured in $250 \mathrm{ml}$ cell culture flasks with $75 \mathrm{ml} \mathrm{FCS}$-free DMEM at $37^{\circ} \mathrm{C}$ and $5 \%$ $\mathrm{CO}_{2}$ for 3 days. After centrifugation at 3,000 $\mathrm{xg}$ and $4^{\circ} \mathrm{C}$ for $15 \mathrm{~min}$ and filtration through a $0.45 \mu \mathrm{m}$ membrane the supernatants were collected and dialyzed in $20 \mathrm{mM}$ sodium phosphate binding buffer $(\mathrm{pH} 7.0)$ at $4^{\circ} \mathrm{C}$ overnight in a SERVAPOR ${ }^{\circledR}$ dialysis tubing with a molecular weight cut-off (MWCO) of 12-14 kDa. Subsequently, the Fc-fusion proteins were purified using $1 \mathrm{ml} \mathrm{HiTrap} \mathrm{Protein} \mathrm{G} \mathrm{HP}$ columns and $100 \mathrm{mM}$ glycine- $\mathrm{HCl}$ elution buffer $(\mathrm{pH}$ 2.7) according to manufacturer's instructions. After a further buffer exchange in PBS (pH 7.2), the purified protein fractions were concentrated using Amicon centrifugal filter units with $30 \mathrm{kDa}$ MWCO according to the manufacturer's protocol. To determine the concentration and purity of the concentrated MICA-129Met-Fc, MICA-129Val-Fc and OVA-Fc proteins, Bio-Rad protein assays (see 2.2.3.2) and reducing sodium dodecyl sulfatepolyacrylamide gel electrophoresis (SDS-PAGE) (see 2.2.3.3) were performed.

Binding puffer: $\quad 40 \mathrm{mM} \mathrm{NaH}_{2} \mathrm{PO}_{4}(1.95 \mathrm{I})$

$40 \mathrm{mM} \mathrm{Na}_{2} \mathrm{HPO}_{4}(3.05 \mathrm{I})$

add to 10 I with $\mathrm{dH}_{2} \mathrm{O}, \mathrm{pH} 7.0$ 


\subsubsection{Bio-Rad protein assay for determination of protein concentration}

The protein concentration of purified Fc-fusion proteins was determined by Bio-Rad protein assays using a Bio-Rad reagent according to the manufacturer's protocol. The Bio-Rad protein assay is based on the Bradford method. It involves the addition of an acidic dye to protein solution and subsequent measurement at $595 \mathrm{~nm}$ with a spectrophotometer or a microplate reader. Comparison to a BSA standard curve reaching from $5 \mu \mathrm{g} / \mathrm{ml}$ to $100 \mu \mathrm{g} / \mathrm{ml}$ provides a relative measurement of protein concentration.

\subsubsection{SDS-polyacrylamide gel electrophoresis (PAGE)}

Discontinuous SDS-PAGE was used for electrophoretic separation of proteins according to their molecular weight. Electrophoresis was performed in a gel electrophoresis system. Therefore, protein samples were supplemented with $1 / 2$ volume $2 x$ protein sample buffer (reducing) and incubated at $95^{\circ} \mathrm{C}$ for 4 min to complete denaturation. Subsequently, samples were loaded and concentrated in the stacking gel at $20 \mathrm{~mA}$ following separation in the separating gel at $40 \mathrm{~mA}$. Proteins were identified by comparison with a prestained protein marker (broad rage, 7-175 kDa). For visualization of proteins, SDS gels were either stained with Coomassie dye (see 2.2.3.4) or subjected to western blot analysis (see 2.2.3.5).

$2 x$ protein sample buffer:

$\begin{array}{ll}100 \mathrm{mM} & \text { Tris- } \mathrm{HCl}, \mathrm{pH} 8.0 \\ 2 \mathrm{mM} & \text { EDTA } \\ 20 \%(\mathrm{v} / \mathrm{v}) & \text { Glycerol } \\ 2 \%(\mathrm{w} / \mathrm{v}) & \text { SDS } \\ 10 \%(\mathrm{v} / \mathrm{v}) & \beta \text {-Mercaptoethanol } \\ 0.1 \%(\mathrm{w} / \mathrm{v}) & \text { Bromphenol blue } \\ \text { dissolved in } & \mathrm{dH}_{2} \mathrm{O}\end{array}$

Stacking gel buffer ( $\mathrm{pH} 6.8)$ :

$0.5 \mathrm{M} \quad$ Tris- $\mathrm{HCl}$

$0.4 \%(\mathrm{w} / \mathrm{v})$ SDS

dissolved in $\mathrm{dH}_{2} \mathrm{O}$

Stacking gel (4.8\%):

$16 \%(\mathrm{v} / \mathrm{v}) \quad$ Acrylamide/Bisacrylamide solution (30\%)

$25 \%(\mathrm{v} / \mathrm{v}) \quad$ Stacking gel buffer

$59 \%(\mathrm{v} / \mathrm{v}) \quad \mathrm{dH}_{2} \mathrm{O}$

$0.01 \%(\mathrm{v} / \mathrm{v})$ TEMED

$0.1 \%(v / v) \quad$ APS (10\%) 


\begin{tabular}{|c|c|c|}
\hline Separating gel buffer ( $\mathrm{pH}$ 8.8): & $\begin{array}{l}1.5 \mathrm{M} \\
0.4 \%(\mathrm{w} / \mathrm{v}) \\
\text { dissolved in }\end{array}$ & $\begin{array}{l}\text { Tris- } \mathrm{HCl} \\
\text { SDS } \\
\mathrm{dH}_{2} \mathrm{O}\end{array}$ \\
\hline Separating gel (10\%): & $\begin{array}{l}33 \%(v / v) \\
22 \%(v / v) \\
45 \%(v / v) \\
0.01 \%(v / v) \\
0.1 \%(v / v)\end{array}$ & $\begin{array}{l}\text { Acrylamide/Bisacrylamide solution (30\%) } \\
\text { Separating gel buffer } \\
\mathrm{dH}_{2} \mathrm{O} \\
\text { TEMED } \\
\text { APS (10\%) }\end{array}$ \\
\hline SDS running buffer: & $\begin{array}{l}25 \mathrm{mM} \\
192 \mathrm{mM} \\
0.1 \%(\mathrm{w} / \mathrm{v}) \\
\text { dissolved in }\end{array}$ & $\begin{array}{l}\text { Tris-HCl } \\
\text { Glycine } \\
\text { SDS } \\
\mathrm{dH}_{2} \mathrm{O}\end{array}$ \\
\hline
\end{tabular}

\subsubsection{Coomassie blue staining}

Proteins in SDS gels were non-specifically stained using Coomassie blue staining solution. The Coomassie Brilliant Blue R-250 dye binds to basic side chains of amino acids. After 15 min incubation with the staining solution at RT and $50 \mathrm{rpm}$, the stained SDS gel was washed with $\mathrm{dH}_{2} \mathrm{O}$ several times until the background color in the SDS gel was removed. The gels were documented by an Intas GDS gel manager.

Coomassie blue staining solution:

$\begin{array}{ll}0.2 \%(\mathrm{w} / \mathrm{v}) & \text { Coomassie Brilliant Blue R-250 } \\ 30 \%(\mathrm{v} / \mathrm{v}) & \text { Methanol } \\ 10 \%(\mathrm{v} / \mathrm{v}) & \text { Acetic acid } \\ \text { dissolved in } & \mathrm{dH}_{2} \mathrm{O}\end{array}$

\subsubsection{Western blot analysis}

After SDS-PAGE (see 2.2.3.3), proteins in the SDS gel were transferred onto a nitrocellulose membrane using a semi-dry blotting technique for subsequent immunostaining. Therefore, a sheet of Whatman paper soaked with blotting buffer was put on the anode of a blotting chamber followed by the nitrocellulose membrane, the SDS gel, a second soaked Whatman paper and the cathode. The protein transfer was performed applying an electric current of $1 \mathrm{~mA} / \mathrm{cm}^{2}$ for $1 \mathrm{~h}$. For staining of specific proteins, unspecific binding of epitopes was inhibited by incubating the membrane in blocking solution at RT for $1 \mathrm{~h}$ on a shaker. Subsequently, the specific primary antibody (see 2.1.5.2) 
diluted in dilution buffer was added to the membrane and incubated at $4^{\circ} \mathrm{C}$ overnight at a respective concentration according to manufacturer's instructions. Following three washing steps with TBS-T at RT for 10 min, a HRP-conjugated secondary antibody diluted in TBS-T at a concentration of 1:10,000 was supplied and incubated at RT for $1 \mathrm{~h}$. After washing of the membrane with TBS-T, the immunostaining of the proteins was visualized using the ECL solution and the digital Intas Chemilux imaging system.

Blotting buffer:

$\begin{array}{ll}48 \mathrm{mM} & \text { Tris } \\ 39 \mathrm{mM} & \text { Glycine } \\ 0.0375 \%(\mathrm{v} / \mathrm{v}) & \mathrm{SDS} \\ 0.01 \%(\mathrm{w} / \mathrm{v}) & \mathrm{NaN}_{3} \\ 20 \%(\mathrm{v} / \mathrm{v}) & \mathrm{Methanol} \\ \text { dissolved in } & \mathrm{dH}_{2} \mathrm{O}\end{array}$

Blocking solution: $\quad 5 \%(\mathrm{w} / \mathrm{v}) \mathrm{BSA}$ in TBS-T

Solution A:

$\begin{array}{ll}250 \mathrm{mg} / \mathrm{l} & \text { Luminol } \\ 100 \mathrm{mM} & \text { Tris- } \mathrm{HCl}, \mathrm{pH} 8.6 \\ \text { dissolved in } & \mathrm{dH}_{2} \mathrm{O}\end{array}$

Solution B:

$55 \mathrm{mg}$ para-coumaric acid/50 ml DMSO

ECL solution:

$4 \mathrm{ml}$ of solution A was freshly mixed with $400 \mu \mathrm{l}$ solution $\mathrm{B}$ and $1.2 \mu \mathrm{l} \mathrm{H}_{2} \mathrm{O}_{2}$

After probing of the blot with a specific $\mathrm{Ab}$ and before further testing of proteins, containing a similar size as previously investigated proteins, the blot was incubated in a $\beta$-mercaptoethanol-containing buffer for $30 \mathrm{~min}$ at $50^{\circ} \mathrm{C}$ in a water bath to detach bound Abs from the proteins on the nitrocellulose membrane. Subsequently, the blot was washed under running tap water until the $\beta$ mercaptoethanol smell disappeared.

$\begin{array}{lll}\text { Stripping buffer: } & 68.5 \mathrm{mM} & \text { Tris- } \mathrm{HCl}, \mathrm{pH} 6.8 \\ & 2 \%(\mathrm{w} / \mathrm{v}) & \mathrm{SDS} \\ & 100 \mathrm{mM} & \beta \text {-mercaptoethanol } \\ & \text { dissolved in } \mathrm{dH}_{2} \mathrm{O}\end{array}$




\subsubsection{Surface plasmon resonance (SPR)}

SPR enables detection of unlabeled interactants in real-time and can be used for determination of protein-protein interaction and binding avidity. SPR analysis was performed with a Reichert SPR Biosensor SR7500DC instrument in PBS running buffer $\left(\mathrm{pH} \mathrm{7.2)}\right.$ at $20^{\circ} \mathrm{C}$. The recombinant NKG2D-Fc fusion protein was covalently immobilized on the EDC/NHS-activated left channel (sample channel) of a 2-dimensional (2D) HC 1000m SPR sensorchip - at a concentration of $200 \mathrm{nM}$, a flow rate of 30 $\mu \mathrm{l} / \mathrm{min}$ and to a response level of 2500 response units (RUs). The right channel of the chip served as a reference. For the kinetic measurements increasing concentrations $(2 \mathrm{nM}, 4 \mathrm{nM}, 8 \mathrm{nM}, 16 \mathrm{nM}, 32$ $\mathrm{nM}, 64 \mathrm{nM}, 125 \mathrm{nM}, 250 \mathrm{nM}$ and $500 \mathrm{nM}$ ) of the analytes MICA-129Met-mlgG ${ }_{2 a}-F c$ or MICA-129Val$\mathrm{mlgG}_{2 \mathrm{a}} \mathrm{Fc}$ fusion proteins, respectively, were injected into the PBS running buffer for 270 seconds over both channels at a flow rate of $40 \mu \mathrm{l} / \mathrm{min}$ with following dissociation for $15 \mathrm{~min}$. Kinetic analysis was performed using the BioLogic software Scrubber 2.0. The recorded responses were double referenced (right channel, buffer blank) and normalized using the molecular weight in kDa of the analytes.

\subsubsection{Cell culture methods}

\subsubsection{Isolation of PBMCs}

Human peripheral blood mononuclear cells (PBMCs) were obtained from heparin-treated peripheral blood of healthy volunteers by density gradient centrifugation on Biocoll separating solution using Leucose ${ }^{\circledR}$ tubes with porous barrier according to manufacturer's instructions.

In brief, after preparation of the Leucosep ${ }^{\circledR}$ tubes the anticoagulated blood, diluted 1:1 with DMEM, was poured directly into the separating tubes and centrifuged at 1,000 $\mathrm{xg}$ and RT for $10 \mathrm{~min}$. The enriched cell fraction was harvested and transferred into a new $50 \mathrm{ml}$ centrifuge tube. Subsequently, PBMCs were washed two times with $10 \mathrm{ml}$ PBS at $250 \times \mathrm{g}$ and then cultured (see 2.2.4.4.2) or subjected to NK cell isolation (see 2.2.4.2).

\subsubsection{NK cell isolation using MACS technology}

The magnetic-activated cell sorting (MACS) method allows the separation of various cell populations depending on their surface antigens by magnetic particles (magnetic MicroBeads) and a magnetic field. NK cells were isolated from human PBMCs (see 2.2.4.1) by the MACS technology using the 
Human NK Cell Isolation Kit from Miltenyi Biotec according to the manufacturer's protocol, in which NK cells are isolated by depletion of non-NK cells (negative selection).

For this purpose, PBMCs were incubated with a specific NK Cell Biotin-Antibody Cocktail at $4^{\circ} \mathrm{C}$ for 10 min. This antibody cocktail comprises various biotin-conjugated monoclonal anti-human antibodies against surface antigens of different PBMC subpopulations not expressed by human NK cells. Subsequently, a NK Cell MicroBead Cocktail containing magnetic MicroBeads conjugated to monoclonal antibodies, which attach to the antibody-labeled cells, was added and incubated at $4^{\circ} \mathrm{C}$ for 15 min. After one washing step, the cell solution was transferred on a MACS LS column placed in a strong magnetic field of a MACS separator. Magnetically labeled non-NK cells were retained on the column, while the unlabeled NK cells pass through and were collected. Purity of NK cells was determined by flow cytometry (see 2.2.5.1) and the percentage of $\mathrm{CD}^{-} \mathrm{CD}^{-} 6^{+}$lymphocytes was determined.

\subsubsection{NK cell stimulation and production of NK cell lysates}

Primary human NK cells purified by MACS technology (see 2.2.4.2) were stimulated with $100 \mathrm{U} / \mathrm{ml}$ recombinant human interleukin-2 (rhIL-2) for 4 days (see 2.2.4.4.2). NK cells were additionally stimulated with recombinant human MICA-129Met/Val-mIgG $\mathrm{za}_{2 \mathrm{a}} \mathrm{Fc}$ fusion proteins to investigate functional effects mediated by these proteins. For cross-linking of the NKG2D receptor on NK cells to MICA-129-Fc homodimers, 96-well Nunc MaxiSorp ${ }^{\mathrm{TM}}$ microtiter plates were pre-coated with 10 $\mu \mathrm{g} / \mathrm{ml}$ of a goat anti-mouse $\mathrm{F}\left(\mathrm{ab}^{\prime}\right)_{2}$ fragment (Jackson ImmunoResearch, Dianova $\mathrm{GmbH}$ ) in $100 \mu \mathrm{l}$ sodium carbonate coating buffer $(\mathrm{pH} 8.5)$ at $4^{\circ} \mathrm{C}$ overnight. After washing the plates with PBS $(\mathrm{pH}$ 7.2), MICA-129Met-Fc, MICA-129Val-Fc or OVA-Fc, respectively, were added to the wells in a total volume of $100 \mu \mathrm{l}$ PBS at various concentrations, ranging from $0.1 \mu \mathrm{g} / \mathrm{ml}$ to $100 \mu \mathrm{g} / \mathrm{ml}$, followed by an incubation at RT for $1 \mathrm{~h}$ and a further washing step. Subsequently, $2.5 \times 10^{5}$ IL-2-activated NK cells in $100 \mu \mathrm{l}$ DMEM were transferred in each well, centrifuged at $1200 \mathrm{rpm}$ for $1 \mathrm{~min}$ and incubated at $37^{\circ} \mathrm{C}$ and $5 \% \mathrm{CO}_{2}$ for $3 \mathrm{~min}, 10 \mathrm{~min}$ or $30 \mathrm{~min}$. Afterwards plates were put on ice and $100 \mu \mathrm{IPBS} /$ EDTA were added to all wells to detach NK cells from the plates. The cell suspension was centrifuged at $1200 \mathrm{rpm}$ and $4^{\circ} \mathrm{C}$ for $10 \mathrm{~min}$ and the supernatant thoroughly removed. $20 \mu \mathrm{l}$ Noidet P-40 (NP-40) lysis buffer were added to $10^{6} \mathrm{NK}$ cells and thoroughly mixed. This mixture was incubated on ice for $20 \mathrm{~min}$ followed by a $20 \mathrm{~min}$ centrifugation at $2500 \mathrm{rpm}$ at $4^{\circ} \mathrm{C}$. The supernatant was then harvested and directly used for SDS-PAGE (see 2.2 .3 .3 ) or aliquots were frozen at $-20^{\circ} \mathrm{C}$.

For performance of CD107a expression assays (see 2.2.5.1.1), stimulation with Fc-fusion proteins was performed as described above in microtiter plates but the NK cell-containing medium was 
additionally supplemented with an anti-CD107a antibody $(4 \mu \mathrm{l} / 100 \mu \mathrm{l}$ DMEM) during the $1 \mathrm{~h}$ incubation period at $37^{\circ} \mathrm{C}$ and $5 \% \mathrm{CO}_{2}$.

Sodium carbonate coating buffer:

$$
\begin{aligned}
& 0.2 \mathrm{M} \quad \mathrm{Na}_{2} \mathrm{CO}_{3}(85 \mathrm{ml}) \\
& 0.2 \mathrm{M} \quad \mathrm{NaHCO}_{3}(40 \mathrm{ml}) \\
& \text { add to } 500 \mathrm{ml} \mathrm{dH} \mathrm{dH}_{2} \mathrm{OH} 8.5
\end{aligned}
$$

PBS/EDTA solution:

1 mM EDTA in PBS, pH 7.2

NP-40 lysis buffer:

$\begin{array}{ll}140 \mathrm{mM} & \mathrm{NaCl} \\ 10 \mathrm{mM} & \text { Tris- } \mathrm{HCl}, \mathrm{pH} 8.0 \\ 1.5 \mathrm{mM} & \mathrm{MgCl}_{2} \\ \text { 0.5\% (w/v) } & \mathrm{NP}-40 \\ \text { dissolved in } & \mathrm{dH}_{2} \mathrm{O}\end{array}$

\subsubsection{Culture of eukaryotic cells}

All target and effector cell lines were cultured in a $5 \% \mathrm{CO}_{2}$ humidified atmosphere at $37^{\circ} \mathrm{C}$. FCS was heated to $56^{\circ} \mathrm{C}$ for $30 \mathrm{~min}$ for inactivation of complement factors. All cell culturing was done under sterile conditions in laminar flow cabinets and with sterile equipment. The sterility of medium additives was assured by manufacturers or achieved by autoclaving or sterile filtration through a 0.2 $\mu \mathrm{M}$ filter unit, if necessary. Centrifugation of eukaryotic cells was performed at $1200 \mathrm{rpm}$ and RT for $5 \min$.

\subsection{Tumor cell culture}

Human and murine tumor cell lines were cultured in DMEM+GlutaMax ${ }^{\mathrm{TM}}$ supplemented with various medium additives as indicated below. Cells were maintained in the exponential growth phase by regular cell passages twice a week. After aspiration of the culture medium, adherent and confluent cells were washed with PBS and subsequently incubated with 0.5-1 ml trypsin/EDTA for approximately 2 min until cells started to detach from the culture dish. For trypsin inactivation, 5-10 ml FCS-containing medium were added. Single cell suspensions were obtained by pipetting the suspension gently up and down. After centrifugation and resuspension in $10 \mathrm{ml}$ fresh medium, approximately $1 / 10$ volume of the cell suspension was passaged into a new cell culture vessel for further cell culture, while the rest of the cells were used for analysis or discarded. 


$\begin{array}{lll}\text { Target cell medium: } & \text { DMEM+GlutaMax } & \\ & +10 \%(\mathrm{v} / \mathrm{v}) & \text { FCS } \\ & +50 \mu \mathrm{M} & 2-\beta-\text { Mercaptoethanol } \\ & +50 \mathrm{U} / \mathrm{ml} & \begin{array}{l}\text { Penicillin } \\ \end{array} \\ & +50 \mu \mathrm{g} / \mathrm{ml} & \text { Streptomycin } \\ & & \\ & & \\ \text { Trypsin/EDTA: } & 0.25 \%(\mathrm{w} / \mathrm{v}) & \text { Trypsin } \\ & 0.02 \%(\mathrm{w} / \mathrm{v}) & \text { EDTA } \\ & \text { dissolved in } & \text { PBS, pH } 7.2\end{array}$

\subsection{Effector immune cell culture}

Primary human PBMCs were obtained by density gradient centrifugation (see 2.2.4.1). NK cells were isolated by MACS separation (see 2.2.4.2). To obtain lymphokine-activated killer (LAK) cells or activated NK cells, PBMCs or isolated NK cells were cultured for 4 days in $5 \mathrm{ml}$ or $10 \mathrm{ml}$ suspension culture dishes in DMEM supplemented with $100 \mathrm{U} / \mathrm{ml}$ rhIL-2. The cell density ranged from $10^{6}$ to $10^{7}$ cells $/ \mathrm{ml}$.

Effector cell medium: $\quad$ DMEM+GlutaMax ${ }^{\mathrm{TM}}$

$\begin{array}{ll}+10 \%(\mathrm{v} / \mathrm{v}) & \text { FCS } \\ +50 \mathrm{U} / \mathrm{ml} & \text { Penicillin } \\ +50 \mu \mathrm{g} / \mathrm{ml} & \text { Streptomycin } \\ +100 \mathrm{U} / \mathrm{ml} & \text { rhlL-2 }\end{array}$

The human non-Hodgkin's lymphoma NK cell line NK-92 was cultured in X-VIVO ${ }^{\text {TM }} 10$ medium optimized for the culture of LAK cells.

NK-92 medium: $\quad$ X-VIVO ${ }^{\text {TM }} 10$ medium

$\begin{array}{ll}+12.5 \%(\mathrm{v} / \mathrm{v}) & \text { FCS } \\ +12.5 \%(\mathrm{v} / \mathrm{v}) & \text { Horse serum, heat-inactivated } \\ +50 \mathrm{U} / \mathrm{ml} & \text { Penicillin } \\ +50 \mu \mathrm{g} / \mathrm{ml} & \text { Streptomycin } \\ +100 \mathrm{U} / \mathrm{ml} & \text { rhlL-2 }\end{array}$




\subsubsection{Freezing and thawing of cells}

Cells were harvested from cell culture dishes depending on their specific growth conditions. Subsequently, cells were centrifuged at $1200 \mathrm{rpm}$ for $5 \mathrm{~min}$ and resuspended in an adequate volume of cell specific medium. $500 \mu \mathrm{l}$ of the cell suspension was transferred into a cryo conservation tube and $500 \mu \mathrm{l} 2 \mathrm{x}$ freezing medium was added. The cell density was about $10^{6}$ cells $/ \mathrm{ml}$. Cryo tubes were slowly frozen in a closed styrofoam box at $-80^{\circ} \mathrm{C}$. After $24 \mathrm{~h}$ cryo tubes were transferred to $-140^{\circ} \mathrm{C}$ for long-term storage.

2x freezing medium: $\quad 20 \%(v / v) \quad$ DMSO $80 \%(v / v) \quad F C S$

Frozen cells were thawed by incubating the cryo tubes briefly in a water bath at $37^{\circ} \mathrm{C}$, diluted in 10 $\mathrm{ml} \mathrm{DMEM} \mathrm{medium} \mathrm{and} \mathrm{centrifuged} \mathrm{for} 5 \mathrm{~min}$ at $1200 \mathrm{rpm}$. Subsequently, cells were resuspended in their specific growth medium and plated in an appropriate cell culture dish.

\subsubsection{Counting of cells}

For cell counting a Neubauer counting chamber and a Zeiss inverted microscope were used. After thorough resuspension of cells in an appropriate volume, $10 \mu \mathrm{l}$ of the suspension were loaded on the loading groove $(0.1 \mathrm{~mm}$ depth) between the chamber and the cover slip. The counting was performed according to manufacturer's instructions of the Neubauer chamber. Before the number of lymphocytes was determined, a 1/10 dilution was prepared by mixing $10 \mu \mathrm{l}$ cell suspension with $90 \mu \mathrm{l}$ $0.4 \%$ trypan blue counting solution. Trypan blue selectively colors dead cells blue. Since living cells are excluded from staining, this staining method is also called trypan blue exclusion method.

Trypan blue counting solution: $\quad 0.4 \%(w / v)$ trypan blue in PBS, pH 7.2

\subsubsection{Transfection of cells}

Linearized plasmid DNA was stably introduced into eukaryotic cells using electroporation. Endotoxinfree and highly purified plasmid DNA was used to increase the transfection efficiency. At first, $10^{7}$ cells were harvested and resuspended in $800 \mu$ l sterile PBS. Subsequently, $50 \mu \mathrm{g}$ DNA were added, the suspension was gently mixed and then transferred into an electroporation cuvette. Electroporation was performed at $250 \mathrm{mV}$ and $960 \mu \mathrm{F}$. After incubation at RT for $5 \mathrm{~min}$, the cells 
were diluted in $10 \mathrm{ml}$ pre-warmed growth medium and seeded in a $10 \mathrm{~cm}$ cell culture dish. Selection procedure of transfected cells started at the earliest $24 \mathrm{~h}$ after electroporation by adding geneticin (G418), which is an aminoglycoside and commonly used as a selective agent for eukaryotic cells. The required G418 concentration, at which untransfected cells of the respective parental cell line died, was tested before $(0.5 \mathrm{mg} / \mathrm{ml}$ or $1 \mathrm{mg} / \mathrm{ml} \mathrm{G} 418$ for HEK293 or Ltk cells, respectively). Approximately 7 days after addition of G418, single cell colonies were picked and plated in 96-well tissue culture plates with $200 \mu \mathrm{l}$ selection medium. Seven to 14 days later stable transfectants were visible and grown for further analysis. Transfection efficiency and selection of stable clones were examined by flow cytometry after staining with respective antibodies (see 2.2.5.1).

Selection medium: $\quad$ DMEM+GlutaMax ${ }^{\mathrm{TM}}$

$\begin{array}{lll}+ & 10 \%(\mathrm{v} / \mathrm{v}) & \text { FCS } \\ + & 50 \mu \mathrm{M} & 2-\beta \text {-Mercaptoethanol } \\ + & 50 \mathrm{U} / \mathrm{ml} & \text { Penicillin } \\ + & 50 \mu \mathrm{g} / \mathrm{ml} & \text { Streptomycin } \\ + & 0.5-1 \mathrm{mg} / \mathrm{ml} & \mathrm{G} 418\end{array}$

\subsubsection{Cell culture for analysis of secreted proteins}

\subsection{Cell culture conditions for the IFN- $\mathrm{E}$ ELISA}

IFN- $\gamma$ ELISAs (see 2.2.5.3.1) were performed to determine the level of this secreted cytokine in the supernatants of primary human NK cells co-cultured with L-con cells, L-MICA-129Met or L-MICA$129 \mathrm{Val}$-expressing target cells, respectively, for $24 \mathrm{~h}$.

Therefore, $5 \times 10^{4}$ target cells in $100 \mu$ medium (see 2.2.4.4.1) were transferred into each well of a 96-well culture plate. Afterwards $2.5 \times 10^{5} \mathrm{NK}$ cells in $100 \mu \mathrm{l}$ medium, stimulated with $100 \mathrm{U} / \mathrm{ml}$ rhIL2 for 4 days (see 2.2.4.4.2), were added in an E:T ratio of 5:1 to each well and centrifuged at 1200 rpm for $2 \mathrm{~min}$ to ensure contact between target and effector cells. The plates were then incubated at $37^{\circ} \mathrm{C}$ and $5 \% \mathrm{CO}_{2}$ in a humidified atmosphere for $24 \mathrm{~h}$. Afterwards the plates were centrifuged at $1200 \mathrm{rpm}$ for $5 \mathrm{~min}$ and the supernatants were harvested by transferring them to a new 96-well plate. If the supernatants were not used directly for the IFN- $\gamma$ ELISA, they were frozen at $-20^{\circ} \mathrm{C}$. 


\subsection{Cell culture conditions for the SMICA ELISA}

Levels of soluble MICA (sMICA) in the supernatants of mouse Ltk $^{-}$and human tumor cell lines, transfected either with the empty vector as negative control or the MICA-129Met or MICA-129Val constructs, were analyzed using the sMICA ELISA (see 2.2.5.3.2).

For this purpose, $10^{6}$ cells of several clones of each MICA-129 variant were cultured in a $10 \mathrm{~cm}$ tissue culture dish (ad $70 \%$ to $90 \%$ confluence) with $10 \mathrm{ml}$ medium (see 2.2.4.4.1) for $24 \mathrm{~h}$. The next day the medium was aspirated and $10 \mathrm{ml}$ fresh medium were added. After $24 \mathrm{~h}$ the supernatant was harvested by centrifugation at $500 \times \mathrm{g}$ and $4^{\circ} \mathrm{C}$ for $5 \mathrm{~min}$. Subsequently, the supernatant was transferred in a new plastic tube, vortexed and 3 aliquots of $1 \mathrm{ml}$ supernatant per cell line were frozen at $-80^{\circ} \mathrm{C}$. After harvesting of the supernatants, the cells were detached from the dishes using trypsin/EDTA to determine the cell number and for analysis of the MICA cell surface expression by flow cytometry (see 2.2.5.1).

\subsubsection{Immunological methods}

\subsubsection{Flow cytometry}

Flow cytometry is a laser-based, biophysical technology which facilitates cell counting and detection of different characteristics of a single cell suspension. Fluorescent dyes can be detected as well as cell size and granularity. Flow cytometry was performed with a BD Biosciences FACScan ${ }^{\mathrm{TM}}$ flow cytometer and CellQuest ${ }^{\mathrm{TM}}$ software.

Cell surface expression of MICA on propidium iodide ( $\mathrm{PI} ; 1 \mu \mathrm{g} / \mathrm{ml}$ ) negative cells was examined using $1 \mu \mathrm{l}$ of the anti-MICA mAb AMO1 per $10^{6}$ cells resuspended in $100 \mu \mathrm{l}$ PBS. The binding of this unlabeled mouse IgG mAb was revealed using a polyclonal FITC-conjugated goat anti-mouse IgG antibody as secondary reagent ( $1 \mu \mathrm{l}$ per $10^{6}$ cells in $\left.100 \mu \mathrm{l} \mathrm{PBS}\right)$. Determination of the MICA cell surface expression on the target cells was performed in parallel to each ${ }^{51} \mathrm{Cr}$ release assay, IFN- $\gamma$ and sMICA ELISA, CD107a expression and NKG2D down-regulation assay. Furthermore, this FITCconjugated anti-mouse antibody was used to detect binding of the recombinant MICA-129Met/Val$m \operatorname{lgG}_{2 a}-\mathrm{Fc}$ or OVA-mlgG $\mathrm{Ia}_{2}-\mathrm{Fc}$ fusion proteins to the NKG2D receptor of primary human NK cells. For the recombinant human NKG2D-Fc chimeric fusion protein $\left(2 \mu \mathrm{l}\right.$ per $10^{6}$ cells in $100 \mu \mathrm{l}$ PBS), which was used to determine the binding avidity of this NKG2D protein to its ligand MICA on target cells, a polyclonal FITC-conjugated goat anti-human IgG antibody served as secondary reagent $\left(1 \mu \mathrm{l}\right.$ per $10^{6}$ cells in $100 \mu \mathrm{PBS})$. 
Characterization of primary human PBMCs, LAK and NK cells enriched and depleted fractions was performed using antibodies reactive against different cell surface epitopes (see 2.1.5.1, Table 2.4).

\subsection{CD107a degranulation assay}

Granule exocytosis of NK cells leads to the expression of the degranulation marker CD107a (also known as LAMP-1) at the NK cell surface, therefore being a sensitive marker for cytotoxic NK cell activity (Alter et al., 2004; Aktas et al., 2009). Thus, CD107a expression of human IL-2-stimulated NK cells co-cultured with L-con, L-MICA-129Met, L-MICA-129Val cells or stimulated with recombinant MICA-129Met/Val-mlgG ${ }_{2 a}-F c$ or OVA-mlgG 2 -Fc fusion proteins, respectively, was measured using an anti-CD107a mAb.

For the co-culture, $10^{6}$ human LAK cells were incubated at an E:T ratio of $25: 1$ with $4 \times 10^{4}$ harvested target cells for $1 \mathrm{~h}$. The effector and target cells were transferred into a FACS tube and centrifuged at $1200 \mathrm{rpm}$ and RT for $5 \mathrm{~min}$. Subsequently, the cells were resuspended in $100 \mu \mathrm{l}$ FCS-containing DMEM and $4 \mu \mathrm{l}$ of the anti-CD107a antibody or the respective $\mathrm{mlgG}_{1}$ isotype control were added. To ensure contact between effector and target cells the tubes were centrifuged again for $5 \mathrm{~min}$ and then incubated at $37^{\circ} \mathrm{C}$ and $5 \% \mathrm{CO}_{2}$ for $1 \mathrm{~h}$. After this time the cells were washed once with PBS, resuspended in $100 \mu \mathrm{l}$ PBS supplemented with anti-CD16 and anti-CD56 antibodies at a concentration according to manufacturer's instructions and incubated in the dark at $4^{\circ} \mathrm{C}$ for $30 \mathrm{~min}$. The staining with these two NK cell markers enabled the gating during flow cytometric analysis on CD56-positive NK cells. Afterwards the cells were washed and resuspended in $300 \mu \mathrm{l}$ PBS for analysis. CD107a expression assays of human NK cells stimulated with MICA-129Met-Fc, MICA-129Val-Fc or OVA-Fc were performed in Nunc MaxiSorp ${ }^{\mathrm{TM}}$ microtiter plates as described above (see 2.2.4.3). NK cell-containing medium was supplemented with the anti-CD107a antibody ( $\mu \mu \mathrm{l} / 100 \mu \mathrm{l}$ DMEM) during an incubation period of $1 \mathrm{~h}$ at $37^{\circ} \mathrm{C}$ and $5 \% \mathrm{CO}_{2}$.

\subsection{NKG2D down-regulation assay}

An anti-NKG2D antibody was used to examine the regulation of this immunoreceptor on human IL-2stimulated NK cells exposed to L-con cells, L-MICA-129Met or L-MICA-129Val-expressing target cells, respectively. In brief, $2.5 \times 10^{5} \mathrm{NK}$ cells in $100 \mu \mathrm{l}$ FCS-containing DMEM were transferred into each well of a 96-well culture plate. Subsequently, $5 \times 10^{4}$ target cells in $100 \mu \mathrm{l}$ medium were added resulting in E:T ratio of 5:1 and the plate was centrifuged at $1200 \mathrm{rpm}$ for $5 \mathrm{~min}$ followed by an incubation at $37^{\circ} \mathrm{C}$ and $5 \% \mathrm{CO}_{2}$ for $4 \mathrm{~h}$ and $24 \mathrm{~h}$, respectively. Afterwards the cell suspensions were 
transferred into FACS tubes and washed with PBS before $5 \mu$ of the PE-labeled anti-NKG2D antibody as well as $5 \mu \mathrm{l}$ of a FITC-labeled anti-CD94 antibody per $100 \mu \mathrm{l}$ PBS were added and incubated in the dark at $4^{\circ} \mathrm{C}$ for $1 \mathrm{~h}$. The CD94 staining served as a control to include a parameter, which was not expected to be down- or up-regulated after co-culture of NK cells with the respective target cells. Afterwards cells were washed and subjected to flow cytometric analysis. For the time point $t=0$, NK cells were directly stained with the anti-NKG2D and anti-CD94 antibody and the receptor expression was then determined.

\subsubsection{Chromium-51 $\left({ }^{51} \mathrm{Cr}\right)$ release assay}

The ${ }^{51} \mathrm{Cr}$ release assay is an in vitro method for quantification of cellular cytotoxicity. ${ }^{51} \mathrm{Cr}$ release assays were performed as previously described (Dressel et al., 2000; Elsner et al., 2007; Elsner et al., 2010) to assess the susceptibility of different target cells to cytotoxic effector cells. The principle of this assay is that target cells labeled with ${ }^{51} \mathrm{Cr}$ release this isotope when lysed by cytotoxic effector cells.

As target cells several clones of the mouse L-MICA-129Met and L-MICA-129Val transfectants were used expressing the MICA cell surface protein of the respective MICA-129 variant. As negative control empty vector-transfected MICA-negative L control (L-con) cells were used, while human erythroleukemia K562 cells, which are known to be highly susceptible to killing by human NK cells, served as positive control. One million harvested target cells were incubated in $100 \mu \mathrm{FCS}$ and $50 \mu \mathrm{Ci}$ $\mathrm{Na}_{2}{ }^{51} \mathrm{CrO}_{4}$ at $37^{\circ} \mathrm{C}$ for $1 \mathrm{~h}$. In between, a serial 1:1 dilution of human LAK cells or NK cells, stimulated with $100 \mathrm{U} / \mathrm{ml}$ rhlL-2 for 4 days, in FCS-containing DMEM $(100 \mu \mathrm{l})$ was prepared in a 96-well plate to achieve different effector to target (E:T) ratios ranging from 200:1 to 3.125:1 for LAK cells or from 20:1 to $0.3125: 1$ for NK cells, respectively. After $1 \mathrm{~h}$ the target cells were washed three times with 10 $\mathrm{ml}$ Hepes-buffered DMEM at $1200 \mathrm{rpm}$ for $10 \mathrm{~min}$ to remove free ${ }^{51} \mathrm{Cr}$, which was not taken up by the cells. Subsequently, $10^{4}$ labeled target cells in $100 \mu$ medium were added to each well of the prepared effector cell dilutions followed by an incubation at $37^{\circ} \mathrm{C}$ and $5 \% \mathrm{CO}_{2}$ for $4 \mathrm{~h}$ in a final volume of $200 \mu \mathrm{l}$. At the end of the $4 \mathrm{~h}$ incubation, the plates were centrifuged at $600 \mathrm{rpm}$ for $3 \mathrm{~min}$. Then 50 $\mu$ l supernatant were removed and transferred into a 96-well Wallac plate. For cell lysis and release of all ${ }^{51} \mathrm{Cr}$ isotopes, $5 \mu \mathrm{l} 10 \%$ Triton- $\mathrm{X}$ were added to each well containing the cell pellets and the remaining $150 \mu \mathrm{l}$ supernatant. After thorough resuspension, $50 \mu \mathrm{l}$ of the sediment part were transferred into another 96-well Wallac plate. All probes were mixed with $200 \mu$ scintillator and sealed with an adhesive film before measurement in the MicroBeta ${ }^{2}$ plate counter was performed. The lysis was calculated according to the following formula: 
$[\%]$ lysis $=\frac{4 \times \text { cpm supernatant } \times 100}{3 \times \text { cpm sediments }+1 \times \mathrm{cpm} \text { supernatant }}$

The assay was performed in triplicates for each target cell line and E:T ratio. The specific lysis of the target cells was calculated by subtracting the values of the spontaneous release $\left({ }^{51} \mathrm{Cr}\right.$ release in the absence of effector cells) from the determined lysis values. The relative lysis compared to K562 cells was calculated to normalize individual experiments. Therefore, the percentage of the specific lysis of K562 cells at the highest E:T ratio (200:1 or $20: 1$ ) was adjusted to $100 \%$ in each test and the relative lysis of the other target cells by LAK or NK cells at different E:T ratios was calculated.

\subsubsection{ELISA}

The ELISA method uses enzyme-linked antibodies and changes in color of a substrate to identify a substance of interest. Within this study, the so-called sandwich ELISA technique was applied using a specific capture antibody and a detection antibody. All ELISAs were performed in 96-well Nunc MaxiSorp ${ }^{\mathrm{TM}}$ microtiter plates and a BioTek PowerWave 340 microplate spectrophotometer was used to measure absorbance at the appropriate wavelength. For coating of the microtiter plates a sodium carbonate coating buffer ( $\mathrm{pH}$ 8.5) was used (see 2.2.4.3). The chemical compound ABTS, which is a redox indicator, served as substrate for the HRP.

$\begin{array}{lll}\text { Substrate buffer: } & 0.1 \mathrm{M} \quad \mathrm{C}_{2} \mathrm{H}_{3} \mathrm{NaO}_{2} \\ & 0.05 \mathrm{M} \quad \mathrm{NaH}_{2} \mathrm{PO}_{4} \\ & \text { dissolved in } \mathrm{dH}_{2} \mathrm{O}, \mathrm{pH} 4.0\end{array}$

ABTS solution: $\quad 40 \mathrm{mM} \mathrm{ABTS}$ in $\mathrm{dH}_{2} \mathrm{O}$

$\begin{array}{lll}\text { Substrate solution: } & 10 \mathrm{ml} & \text { Substrate buffer } \\ & 500 \mu \mathrm{l} & \text { ABTS solution } \\ & 10 \mu \mathrm{l} & \mathrm{H}_{2} \mathrm{O}_{2}(30 \%)\end{array}$

\subsection{IFN- $\gamma E L I S A$}

To determine IFN- $\gamma$ levels in the supernatants after $24 \mathrm{~h}$ co-culture of primary human NK cells with Lcon cells, L-MICA-129Met or L-MICA-129Val-expressing target cells (see 2.2.4.8.1), ELISAs were 
performed using the human IFN- $\gamma$ ELISA set from ImmunoTools according to the manufacturer's protocol.

Briefly, a Nunc microtiter plate was coated with the coating antibody against IFN- $\gamma$ in a total volume of $100 \mu \mathrm{l}$ coating buffer. The plate was sealed and incubated at $4^{\circ} \mathrm{C}$ overnight. After washing the plate five times with PBS, $200 \mu$ l blocking buffer (1\% BSA in PBS) were added per well before the plate was covered and incubated at RT for $1 \mathrm{~h}$. Followed by five times washing of the plate with washing buffer (0.005\% Tween-20 in PBS), $100 \mu \mathrm{l}$ of the respective supernatants or the diluted IFN- $\gamma$ standard were added to the wells. After an incubation period, the plate was washed and the biotinylated anti-human IFN- $\gamma$ antibody was added to the wells. After further incubation for $1 \mathrm{~h}$ and washing, a streptavidin-HRP conjugate was added. This time the plate was incubated at RT for 30 min. After a last washing step, $100 \mu \mathrm{l}$ ABTS substrate solution (see 2.2.5.3) were added to each well and the plate was incubated at RT in the dark. Experiments were performed in duplicates for all samples. Measurement of absorbance was performed at $405 \mathrm{~nm}$ and $490 \mathrm{~nm}$ for calculation of $\Delta$ optical density (OD) BLANK values within the next $10 \mathrm{~min}$ in a microplate spectrophotometer. The amount of IFN- $\gamma$ in each well was determined by extrapolating absorbance values to IFN- $\gamma$ concentrations using a standard curve of recombinant human IFN- $\gamma$.

\subsection{SMICA ELISA}

Levels of sMICA proteins in the supernatants of MICA-129-transfected or empty vector-transfected mouse Ltk' and human tumor cell lines, produced as described above (see 2.2.4.8.2), were analyzed using the human MICA DuoSet ELISA from R\&D Systems. The ELISA was conducted according to manufacturer's instructions. All samples were investigated in duplicates and the amount of sMICA in each well was determined by extrapolating absorbance values to sMICA concentrations by means of a standard curve using a recombinant human MICA protein.

\subsubsection{3 mlgG screening ELISA}

The mlgG screening ELISA was used to select HEK293-MICA-129-mlgG $\lg _{2 \mathrm{a}}-\mathrm{Fc}$ and OVA-mlgG $2 \mathrm{a}-\mathrm{Fc}-$ secreting clones. Therefore, Nunc microtiter plates were coated with $10 \mu \mathrm{g} / \mathrm{ml}$ of a goat anti-mouse IgG antibody diluted in $50 \mu \mathrm{l}$ coating buffer per well, incubated at $4^{\circ} \mathrm{C}$ overnight and then blocked with $150 \mu$ l 1\% gelatin in PBS. After washing $50 \mu$ l of the corresponding cell culture supernatants or 2 $\mu \mathrm{l}$ of mouse IgG serum $(10 \mu \mathrm{g} / \mathrm{ml})$ diluted in $48 \mu \mathrm{l}$ medium, which served as positive control, were added to each well and incubated at $37^{\circ} \mathrm{C}$ for $1 \mathrm{~h}$. For detection, a goat anti-mouse HRP-conjugated 
antibody diluted 1:4000 in PBS with 0.05\% Tween-20 was added and the plates were incubated again at $37^{\circ} \mathrm{C}$ for $1 \mathrm{~h}$. After a further washing step, $50 \mu \mathrm{ABTS}$ substrate solution (see 2.2.5.3) were added to each well and the OD values were determined after 5 min using a microplate spectrophotometer set to $405 \mathrm{~nm}$.

\subsubsection{Histology}

\subsubsection{Hematoxylin and eosin (H\&E) staining}

For histopathological examination, paraffin sections of tumor tissue $(2.5 \mu \mathrm{m})$ were stained using the H\&E staining method. After incubation of the paraffin sections at $37^{\circ} \mathrm{C}$ overnight or at $60^{\circ} \mathrm{C}$ for 30 min, tissue sections were deparaffinized using xylol $(2 \times 7 \mathrm{~min})$, rehydrated in a descending alcohol series (ethanol $98 \%, 75 \%$ and $60 \%$ for 5 min each step) and put into $\mathrm{dH}_{2} \mathrm{O}$ for $5 \mathrm{~min}$. For H\&E staining, the samples were incubated in Mayer's hemalum solution for $5 \mathrm{~min}$, rinsed with $\mathrm{dH}_{2} \mathrm{O}$ for $5-10$ min and incubated in eosin for additional $5 \mathrm{~min}$. Subsequently, sections were briefly incubated in $\mathrm{dH}_{2} \mathrm{O}$ followed by an ascending alcohol series (60\%, $75 \%$ and $98 \%$ ethanol). After a 5 min incubation in $98 \%$ ethanol, sections were transferred into isopropanol for $5 \mathrm{~min}$ and then incubated two times in xylol for 5 min before they were embedded using the Roti ${ }^{\circledR}$-Histokitt. Hemalum, the complex formed from aluminium ions and hematein, which is an oxidation product of hematoxylin, colors nuclei of cells blue, while eosin colors eosinophilic structures such as the cytoplasm of cells as well as extracellular proteins in various shades of red, pink and orange. If staining of specific proteins was of interest, additional immunohistochemistry was performed (see 2.2.6.2).

$\begin{array}{lll}\text { Eosin solution: } & 1 \% & \text { Eosin } \\ & 200 \mu \mathrm{l} & \text { Acetic acid } \\ & \text { add to } 100 \mathrm{ml} & \mathrm{dH}_{2} \mathrm{O}\end{array}$

\subsubsection{Immunohistochemistry}

For immunohistochemistry, paraffin sections were stained with specific antibodies to detect proteins of interest. After deparaffinization and rehydration in a descending alcohol series (see 2.2.6.1), tissue sections were cooked three times in citrate buffer for 5 min for antigen retrieval. Subsequently, the sections were blocked with 4\% BSA in PBS for $1 \mathrm{~h}$ before incubation with a biotinylated goat antihuman MICA antibody, diluted 1:5 in PBS with $1 \%$ BSA, at $4^{\circ} \mathrm{C}$ overnight. Tissue sections were 
incubated in $3 \% \mathrm{H}_{2} \mathrm{O}_{2}(30 \%)$ in $\mathrm{PBS}$ at $\mathrm{RT}$ for 10 min to block endogenous peroxidases. Afterwards streptavidin-HRP diluted 1:200 in PBS was added and sections were incubated at RT for $1 \mathrm{~h}$. The sections were stained with a DAB substrate solution and then embedded using the Roti ${ }^{\circledR}$-Histokitt according to manufacturer's instructions. If preferable, before embedding an additional staining with Mayer's hemalum solution followed by an ascending alcohol series was performed (see 2.2.6.1).

Citrate buffer:

$0.1 \mathrm{M} \quad$ Citric acid $\left(\mathrm{C}_{6} \mathrm{H}_{8} \mathrm{O}_{7} ; 9 \mathrm{ml}\right)$

$0.1 \mathrm{M} \quad$ Sodium citrate $\left(\mathrm{NaC}_{6} \mathrm{H}_{5} \mathrm{O}_{7} ; 41 \mathrm{ml}\right)$

add to $500 \mathrm{ml} \mathrm{dH_{2 } \mathrm { O }}$

DAB substrate solution: $0.05 \% \quad \mathrm{DAB}$

$0.015 \% \quad \mathrm{H}_{2} \mathrm{O}_{2}$

dissolved in PBS

\subsubsection{Animal experiments}

\subsubsection{Inoculation of tumor cells}

L-MICA-129Met, L-MICA-129Val or L-con cells, respectively, cultured in vitro (see 2.2.4.4.1) were harvested, washed two times with PBS and adjusted to $10^{6}$ or $5 \times 10^{6}$ cells $/ 100 \mu \mathrm{PBS}$. Subsequently, $100 \mu \mathrm{l}$ of the cell suspension were subcutaneously (s.c.) injected into the flank of manually immobilized mice (see 2.1.9, Table 2.8) using a $1 \mathrm{ml}$ syringe with a $26 \mathrm{G}$ needle. Tumor growth was monitored by palpation and tumor size was recorded using a linear caliper. Tumor volume was calculated by the formula $V=\pi a b c / 2$, where $a, b, c$ are the orthogonal diameters.

\subsubsection{Adoptive NK cell transfer}

For the adoptive NK cell transfer, human NK cells were isolated via MACS technology (see 2.2.4.2) from peripheral blood and stimulated in vitro for 4 days with $100 \mathrm{U} / \mathrm{ml}$ rhIL-2 (2.2.4.4.2). After washing the cells twice with PBS, $10^{6}$ to $5 \times 10^{6} \mathrm{NK}$ cells/100 $\mu$ I PBS were intravenously (i.v.) injected into the tail vein of immunodeficient C.B.-17-SCID or C57BL/6-Rag $2^{-1} / \mathrm{cyc}^{-/-}$mice (see 2.1.9, Table 2.8), which were inoculated with tumor cells into the flank (see 2.2.7.1) 4 days before, using a $1 \mathrm{ml}$ syringe and a $26 \mathrm{G}$ needle. 


\subsubsection{Sacrification and tissue preparation}

The mice were sacrificed in a $\mathrm{CO}_{2}$ atmosphere when a tumor volume of $1 \mathrm{~cm}^{3}$ was reached or when weight loss ( $>20 \%$ for more than $48 \mathrm{~h}$ ) or any signs of pain were recorded. Blood was directly gained by heart puncture using a $1 \mathrm{ml}$ syringe and one part of the fresh blood was transferred in an EDTAcontaining $1 \mathrm{ml}$ plastic tube. For flow cytometric analysis, the blood was stained with antibodies of interest and erythrocytes were lysed with FACS $^{\text {TM }}$ lysis solution according to manufacturer's instructions. The other part of the blood was added into a $1.5 \mathrm{ml}$ reaction tube, incubated for $1 \mathrm{~h}$ at RT followed by $1 \mathrm{~h}$ at $4^{\circ} \mathrm{C}$. Subsequently, the blood was centrifuged at 10,000 rpm at RT for $5 \mathrm{~min}$. The serum was carefully transferred into a fresh tube and the centrifugation step repeated. Afterwards the serum was stored at $-20^{\circ} \mathrm{C}$. After blood taking, the primary tumor was prepared and cut into three parts. One part was placed in phosphate-buffered $4 \%$ formalin for $16 \mathrm{~h}$ and then embedded in paraffin. Tissue sections were stained with H\&E (see 2.2.6.1). The second part was immediately frozen in liquid nitrogen for gene expression analyses and the third part was stored in medium on ice for subsequent flow cytometry. Then autopsies were continued and the abdomen and thoracic cavity were examined systematically for the presence of metastases. The spleen, liver and lung were prepared to look for transferred NK cells by flow cytometry. The tumor sample for flow cytometry was cut into small pieces and incubated in medium supplemented with collagenase $(1 \mathrm{mg} / \mathrm{ml})$ and DNase I $(20 \mathrm{U} / \mathrm{ml})$ in a thermoblock at $500 \mathrm{rpm}$ and $37^{\circ} \mathrm{C}$ for $1 \mathrm{~h}$. The other tissues were passed through a $40 \mu \mathrm{m}$ nylon mesh with ice-cold PBS or DMEM using a syringe plug. The cell suspensions of the different tissues were centrifuged at $1200 \mathrm{rpm}$ for $10 \mathrm{~min}$ and the pellet resuspended in PBS followed by a further centrifugation step. Before antibody staining for investigation by flow cytometry, the homogenized spleen was additionally treated with erythrocyte lysis buffer.

$\begin{array}{lll}\text { Erythrocyte lysis buffer: } & 155 \mathrm{mM} \quad \mathrm{NH}_{4} \mathrm{Cl} \\ & 10 \mathrm{mM} \quad \mathrm{KHCO}_{3} \\ & 0.1 \mathrm{mM} \quad \mathrm{EDTA} \\ & \text { dissolved in } & \mathrm{dH}_{2} \mathrm{O}, \mathrm{pH} 7.2\end{array}$

\subsubsection{Clinical study population}

In this study, 320 consecutive patients (Ps), who underwent allogeneic HSCT in the Department of Hematology and Medical Oncology in the University Medical Center Göttingen between October 
2002 and March 2011, and their donors (Ds) were included. Approval for the analysis was obtained from the Institutional Review Board of the Göttingen University Medical Center and was conducted according to the Declaration of Helsinki. The SNP rs1051792 (A/G), which is responsible for the MICA129Met/Val dimorphism, was genotyped by a TaqMan MICA-129 genotyping assay (see 2.2.2.3.4).

\subsubsection{Statistical analysis}

Statistical analysis was performed using WinStat software. If not otherwise indicated, student's unpaired $t$ test and analysis of variance (ANOVA) were used. Data are depicted as mean \pm standard deviation (SD) or standard error of the mean (SEM). A $P$ value of less than $0.05\left({ }^{*}\right)$, less than $0.01\left({ }^{* *}\right)$ or less than $\left.0.001{ }^{* * *}\right)$ was considered statistically significant, whereas n.s. means not significant.

More complex statistical models for the analysis of the ${ }^{51} \mathrm{Cr}$ release assays, CD107a expression assays, NKG2D down-regulation experiments, IFN- $\gamma$ ELISAs and of the clinical study cohort undergoing HSCT were performed by statisticians from the Department of Genetic Epidemiology of the UMG.

The experimental data were evaluated with the WinStat software employing $t$ tests or two-way ANOVAs with interactions. The SAS software was used to estimate linear mixed models with adjustment for the interaction with MICA expression level. Dependent on the experimental design, random effects were included into the models to account for the longitudinal correlation (relative cell lysis; cell surface expression of NKG2D and CD94) or for a random trial effect (IFN- $p$ release).

Statistical analyses of clinical and genotyping data were performed with R software (http://www.Rproject.org). The analysis comprised patient/donor (P/D) pairs matched on the MICA-129 genotype (274 pairs) and the whole dataset (320 pairs). The influence of the MICA-129 dimorphism on the outcome in HSCT patients was evaluated. The outcome parameters were occurrence of aGVHD, occurrence of cGVHD, occurrence of relapse, treatment-related mortality (TRM), death due to aGVHD (probability of event analysis with logistic regression) and overall survival (time to event analysis with Cox proportional hazard models). Important clinical covariates (donor gender, $\mathrm{T}$ cell depletion, reduced intensity conditioning and HLA-matched unrelated donor) were identified and adjusted for in all analyses. The co-dominant model was employed to determine the most appropriate risk model (additive, dominant or recessive). Reported are the results of the most appropriate genetic model. 


\section{Results}

\subsection{MICA-129Met/Val gene expression in L-MICA-129 transfectants}

To study the functional effects of the MICA-129Met/Val polymorphism, we generated cells expressing MICA variants differing only at position 129. For this purpose, a pCMV6-AC expression vector containing the MICA gene (Origene) was purchased and subsequently sequenced. Two positions in this construct, encoding the amino acid positions 24 and 360 of the MICA protein, had to be altered by site-directed mutagenesis to obtain the human MICA*00701 allele, which contains a Met at amino acid position 129. The MICA-129Val variant (pCMV6-AC-MICA-129Val) of the MICA*00701 allele was generated by site-directed mutagenesis of the pCMV6-AC-MICA-129Met construct. NK cell-resistant mouse fibroblast tumor L cells were stably transfected with these constructs, since the MICA gene and its homolog MICB are not present in the mouse genome. During the screening for stable L-MICA-129Met and L-MICA-129Val clones, we observed that clones of the MICA-129Met variant with high MICA cell surface expression were rare. After prolonged selection with G418, we finally got stable L-MICA-129Met clones with similar expression levels as L-MICA$129 \mathrm{Val}$ clones. Altogether, a broad range of MICA expression intensities was reached on different clones for both variants as shown in Figure 3.3 $\mathrm{D}$ and $\mathrm{E}$ (section 3.2.1).

To determine whether the MICA mRNA expression level differs between the two MICA-129 variants, mRNA was isolated from several clones of each MICA-129 variant and after cDNA synthesis qRT-PCRs were performed. For normalization of mRNA amounts of the MICA target gene (tg), Hprt (hypoxanthine-guanine phosphoribosyltransferase) was used as housekeeping gene (hkg). In parallel, the MICA protein expression was determined by flow cytometry. The statistical analysis revealed no significant difference in the MICA protein expression intensity between the two MICA-129 variants in these experiments $(P=0.2132$, t test) but a significant difference in the MICA mRNA expression level $(P=0.0212, \mathrm{t}$ test $)$ as depicted in Figure 3.1 A. These data suggest that for the MICA-129Met variant higher amounts of MICA mRNA are required than for the MICA-129Val variant to obtain a similar MICA protein expression level at the cell surface. Additionally, the MICA cell surface expression appears to be more directly dependent on the MICA gene expression level for the MICA-129Val than the MICA-129Met variant as indicated by a higher coefficient of determination $\left(R^{2}\right)$ (Figure $3.1 \mathrm{~B}$ ). 
A

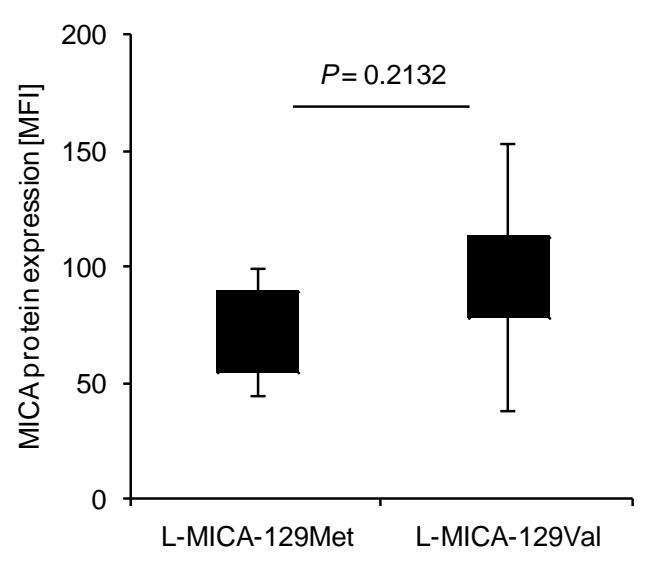

B

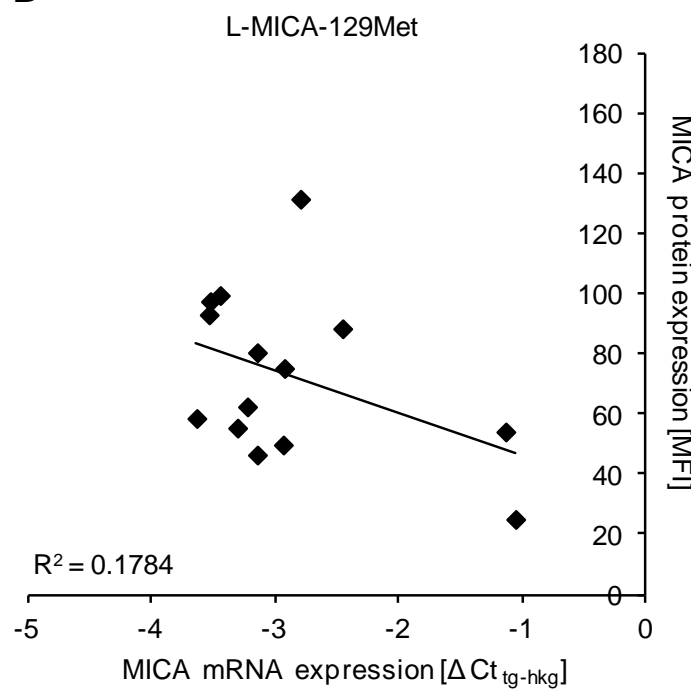

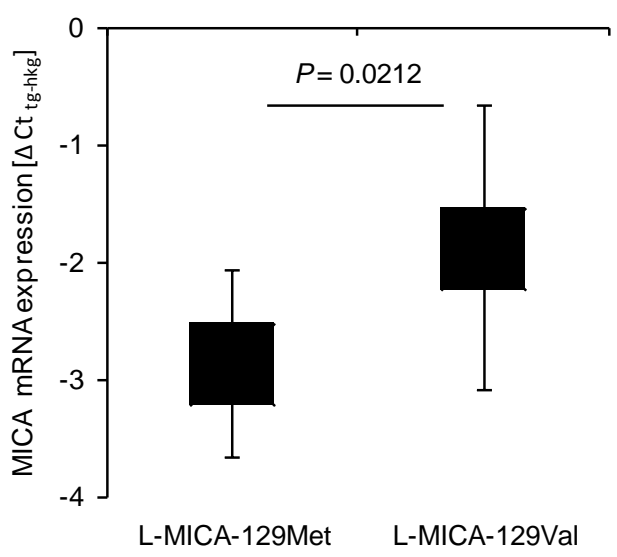

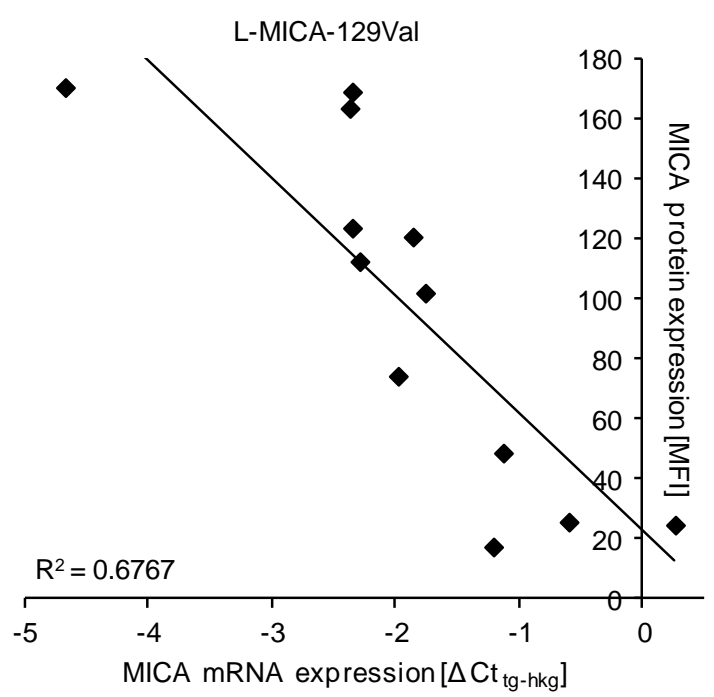

Figure 3.1: MICA mRNA expression significantly differs between the MICA-129Met and MICA-129Val variants.

(A) Diagrams represent the MICA protein expression (MFI = mean fluorescence intensity, left panel) and MICA gene expression ( $\Delta \mathrm{Ct}_{\mathrm{tg}-\mathrm{hkg}}$, right panel) of L-MICA-129Met $(n=14)$ and L-MICA-129Val $(n=12)$ clones cultured under normal conditions. MICA gene expression and MICA protein expression were determined by qRT-PCR and flow cytometry, respectively. Expression values of the target gene ( $\mathrm{tg}$ ) MICA were calculated from mean of technical triplicates after normalization to the housekeeping gene (hkg) Hprt. The data were compared by an unpaired $\mathrm{t}$ test and are shown in box-and-whisker plots. It should be noted that lower $\Delta \mathrm{Ct}_{\mathrm{tg} \text {-hkg }}$ values indicate higher mRNA expression levels. (B) The linear regression of MICA gene expression and MICA protein expression is shown for L-MICA-129Met (left panel) and L-MICA-129Val cells (right panel). The regression line and the coefficient of determination $\left(R^{2}\right)$ are indicated for $L$ cells expressing the MICA-129 variants. 


\subsection{Influence of the MICA-129Met/Val polymorphism on binding avidity}

Two experimental systems were used to analyze the interaction of NKG2D and MICA-129Met/Val. Firstly, we stably transfected MICA-negative mouse L cells with MICA-129Met or Val expression constructs as described above (section 3.1) and determined the binding of a recombinant NKG2D-Fc fusion protein. Secondly, we produced the MICA-129Met/Val variants as recombinant mouse $\operatorname{lgG}_{2 a}-\mathrm{Fc}$ fusion proteins in HEK293 cells and analyzed their binding to primary human NK cells.

\subsubsection{Binding of NKG2D-Fc fusion protein to L-MICA-129 cells}

In order to investigate the influence of the MICA-129Met/Val polymorphism on NKG2D binding avidity, we analyzed the binding of NKG2D to the MICA-129Met/Val-transfected L cells. Both the LMICA-129Met and L-MICA-129Val cells, in contrast to empty vector-transfected L control (L-con) cells, expressed the MICA ligand at the cell surface and bound a soluble NKG2D protein (Figure 3.2) as shown by flow cytometry using an anti-MICA mAb and a recombinant human NKG2D-Fc fusion protein.

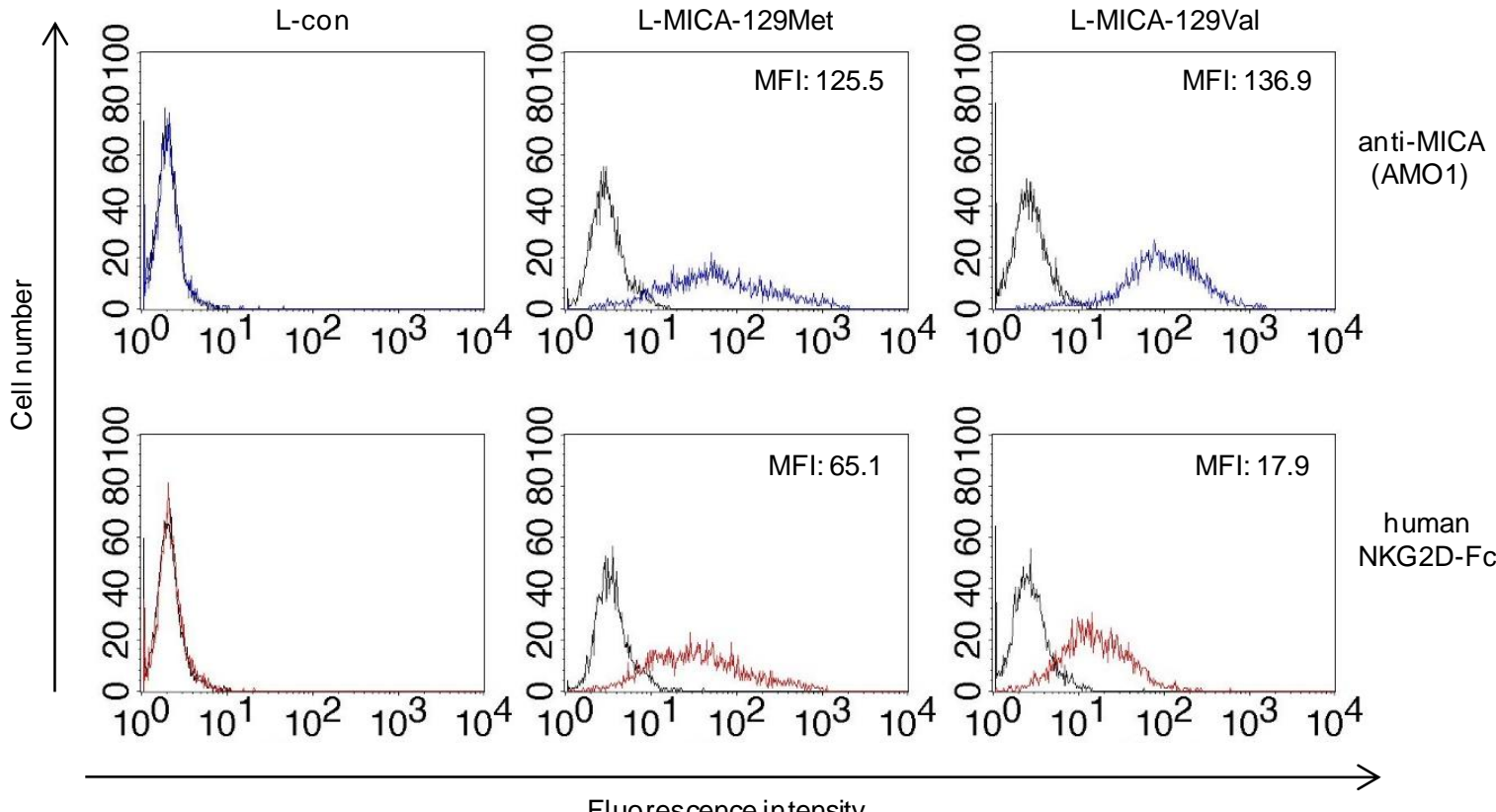

Figure 3.2: L-MICA-129Met and L-MICA-129Val cells, in contrast to vector-only transfected L-con cells, bind a recombinant human NKG2D-Fc fusion protein.

The expression of MICA was analyzed by flow cytometry on L-con, L-MICA-129Met and L-MICA-129Val cells using a primary mouse anti-human MICA mAb in combination with a FITC-conjugated goat anti-mouse IgG Ab as secondary reagent. In parallel, the binding of a recombinant human NKG2D-Fc fusion protein was measured using a FITC-conjugated goat anti-human IgG as secondary Ab. Staining with the respective primary reagent plus secondary Ab (blue or red line) and FITC-labeled secondary Ab only (black line) is shown. The MFIs of MICA expression and NKG2D binding determined by these measurements are indicated. 
A broad range of MICA expression intensities was reached on different clones but these were on average similar ( $P=0.3690$, $\mathrm{t}$ test) for both variants (Figure $3.3 \mathrm{~A}$ ). However, the binding of NKG2D to both MICA-129 variants appeared to be different (Figure 3.3 B), although only at borderline level ( $P=$ $0.0808, t$ test). Analysis of the ratios of MICA expression and NKG2D binding (Figure $3.3 \mathrm{C}$ ) clearly revealed a higher avidity of the MICA-129Met than MICA-129Val variant for NKG2D $(P=0.0016, \mathrm{t}$ test). Moreover, the binding of NKG2D to the MICA-129Met isoform was more dependent on the intensity of MICA expression (coefficient of determination $R^{2}=0.62$ ) than binding to the MICA-129Val isoform $\left(R^{2}=0.39\right)$. The slope of NKG2D binding with increasing MICA expression intensity was steeper for the MICA-129Met (Figure 3.3 D) than for the MICA-129Val variant (Figure 3.3 E). Thus, the L-MICA-129Met variant binds NKG2D with higher avidity than the L-MICA-129Val variant.

A

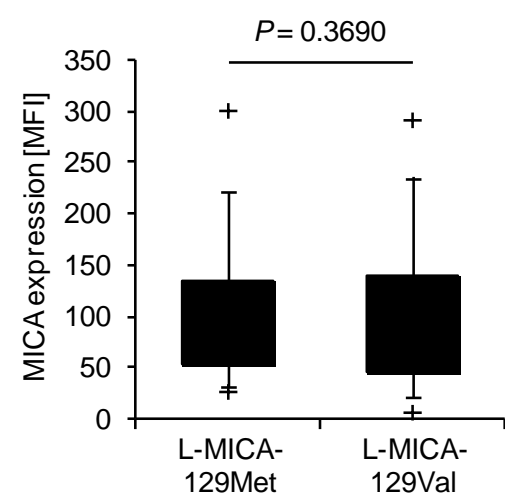

D

L-MICA-129Met

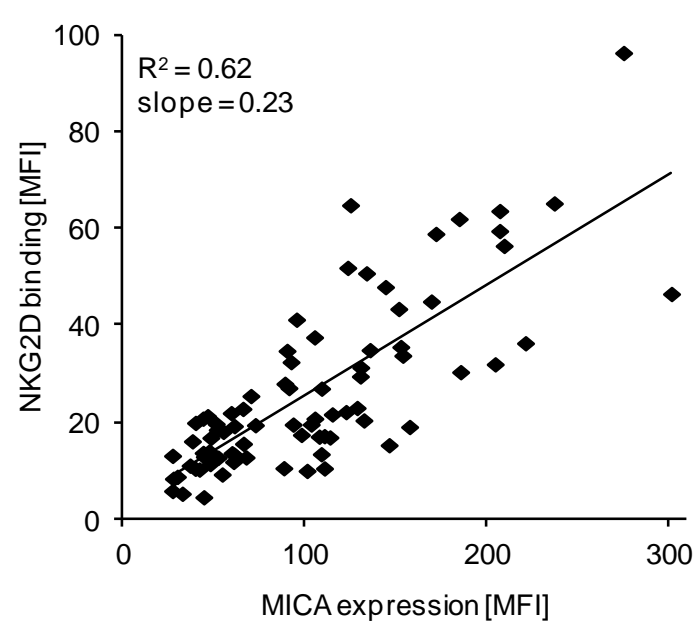

B

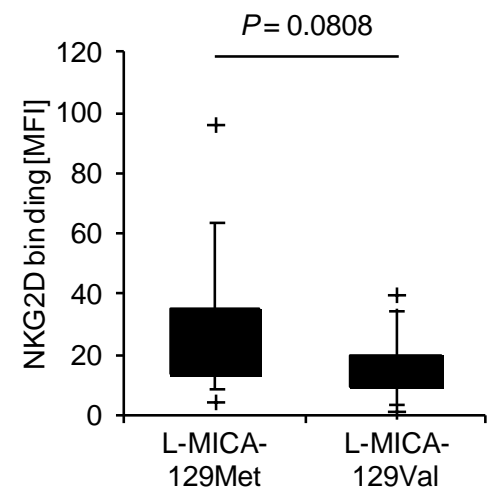

E
C

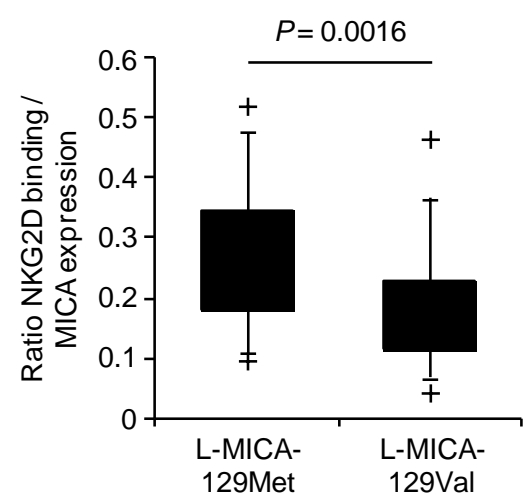

Figure 3.3: The MICA-129Met variant binds NKG2D with higher avidity than the MICA-129Val variant.

(A) The MICA expression intensity on L-MICA-129Met $(n=79)$ and L-MICA-129Val cells $(n=81)$ was determined as MFI by flow cytometry and is shown in box-and-whisker plots. The data were compared by an unpaired $t$ test. (B) In parallel, the binding of a recombinant NKG2D-Fc fusion protein to the L-MICA-129Met and L-MICA- 
$129 \mathrm{Val}$ cells was measured by flow cytometry and the MFIs are shown in box-and-whisker plots. A difference between the cell lines was assessed by an unpaired t test. (C) The ratios of the NKG2D binding and MICA expression for the L-MICA-129Met and L-MICA-129Val cells are summarized in box-and-whisker plots revealing a difference between the MICA-129 variants in NKG2D binding (unpaired t test). (D) The linear regression of MICA expression and NKG2D binding both determined as MFI is shown for the L-MICA-129Met and (E) L-MICA$129 \mathrm{Val}$ cells. The slope of the regression line and the coefficient of determination $\left(R^{2}\right)$ are indicated for both MICA variants.

\subsubsection{Binding of MICA-129-Fc fusion proteins to NKG2D of human NK cells}

In addition to the L-MICA-129 cell lines, recombinant mouse $\lg _{2 a}-\mathrm{Fc}$ fusion proteins of both MICA129 variants were produced to analyze binding of these proteins to NKG2D of primary human NK cells. Therefore, pcDNA3.1-MICA-129-mlgG $\mathrm{g}_{2 \mathrm{a}}$-Fc expression constructs of both variants were used for stable transfection of HEK293 cells which then secret the fusion proteins as MICA homodimers into the cell supernatant. We chose the $\mathrm{mlgG}_{2 \mathrm{a}} \mathrm{Fc}$ part to minimize cross-reactions with human NK cells. Protein purification was performed by affinity chromatography using Protein $\mathrm{G}$ sepharose columns binding the Fc part of the fusion proteins. The purified MICA-129Met-mlgG ${ }_{2 a}-F c$ and MICA-129Val$\mathrm{mlgG}_{2 \mathrm{a}} \mathrm{Fc}$ proteins were separated by SDS-PAGE and stained with Coomassie blue or probed with an anti-MICA mAb and an anti-mouse IgG polyclonal Ab on immunoblots. Both assays revealed the proteins at a size of approximately $90 \mathrm{kDa}$ (Figure $3.4 \mathrm{~A}$ ). The expected size of the fusion proteins calculated based on the nucleotide sequence using a peptide molecular weight calculator offered by genscript (https://www.genscript.com/ssl-bin/peptide_mw) was $61 \mathrm{kDa}$. Since MICA proteins are glycosylated, deglycosylation was performed with a recombinant fusion protein of endoglycosidase $\mathrm{H}$ (Endo $\mathrm{H}_{\mathrm{f}}$, apparent molecular weight of $70 \mathrm{kDa}$ ), which cleaves within the chitobiose core of high mannose and some hybrid oligosaccharides from $\mathrm{N}$-linked glycoproteins. SDS-PAGE after Endo $\mathrm{H}_{\mathrm{f}}$ digestion showed now a protein size of approximately $80 \mathrm{kDa}$ (Figure $3.4 \mathrm{C}$ ). Herein, it is to consider that Endo $\mathrm{H}_{\mathrm{f}}$ is a glycosidase, which only partly deglycosylates proteins. An OVA-mlgG ${ }_{2 a}-\mathrm{Fc}$ fusion protein was generated as a control protein and showed a size of about $70 \mathrm{kDa}$ after SDS-PAGE and immunoblotting with an anti-OVA mAb (Figure 3.4 B). 
A

A

$\mathrm{kDa}$
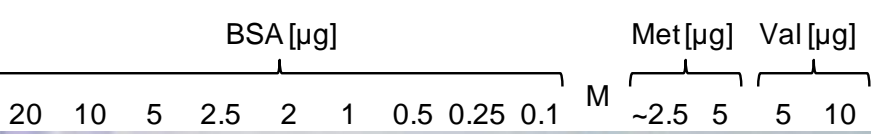

175

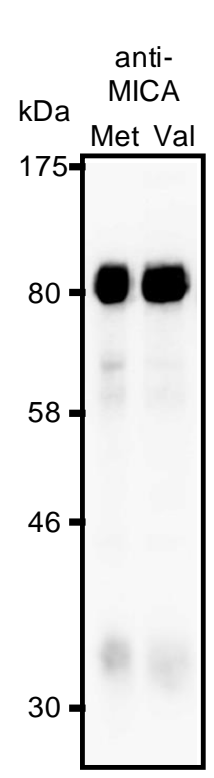

anti-

mouse

$\lg G$

80

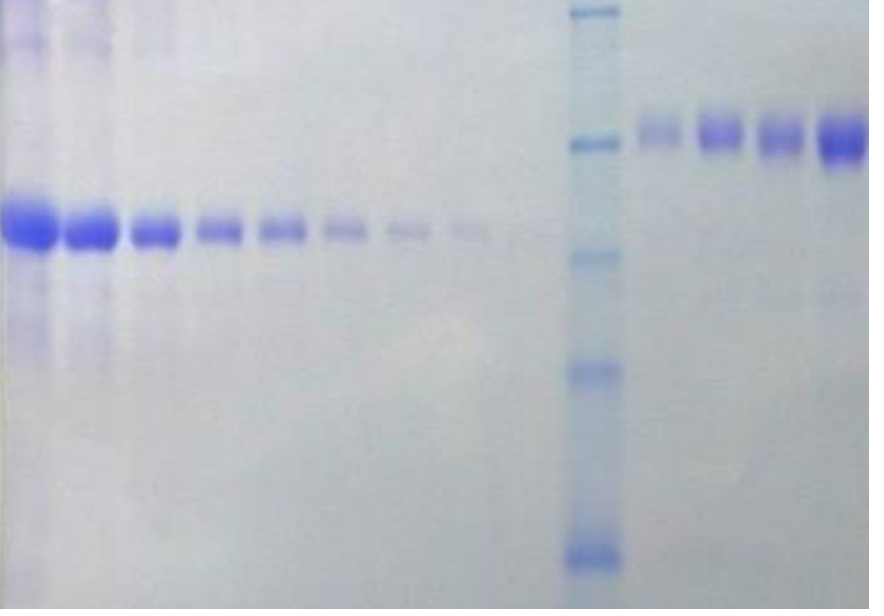

58

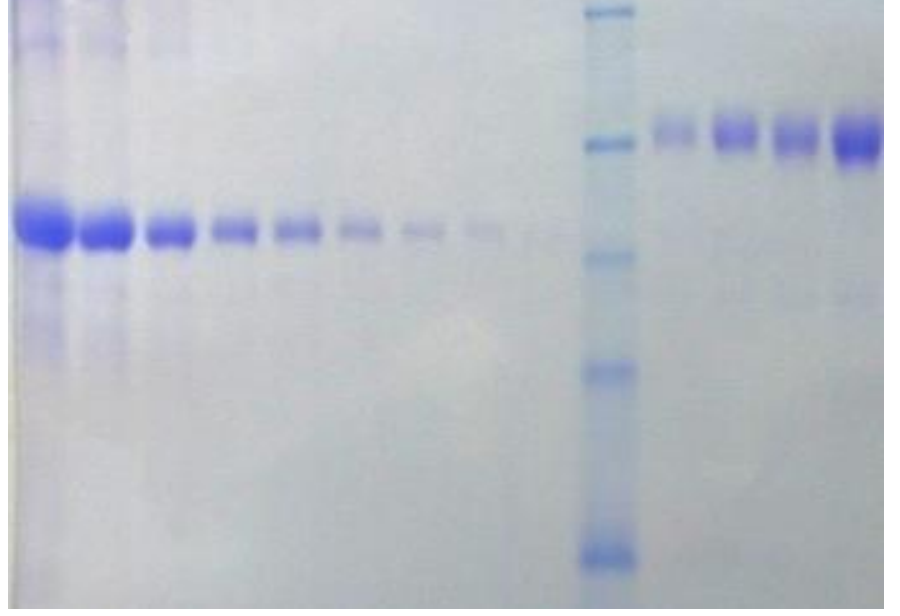

$\mathrm{kDa}$

Met Val

46

30

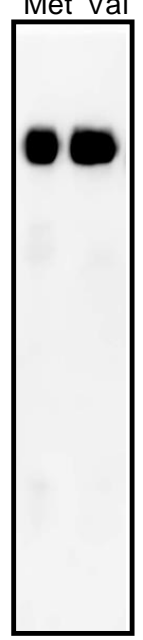

B OVA-FC

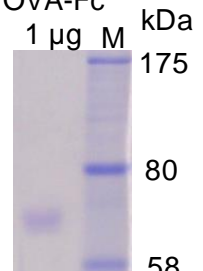

C

58

46

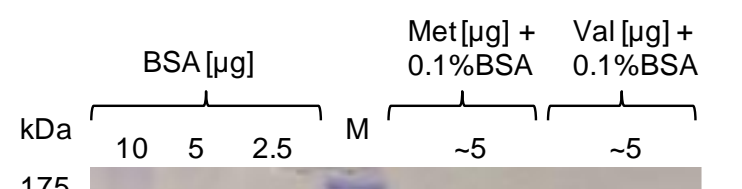

30
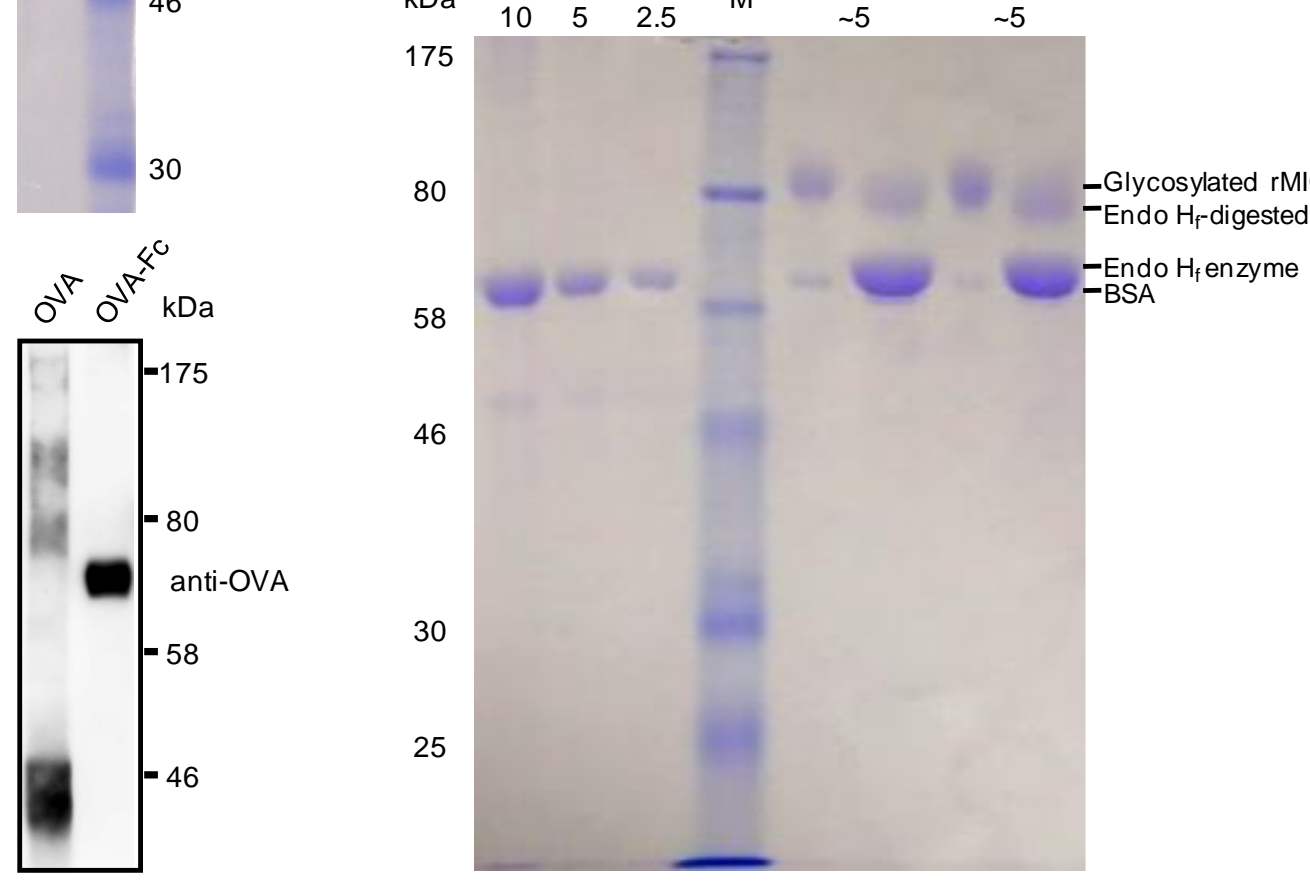

46

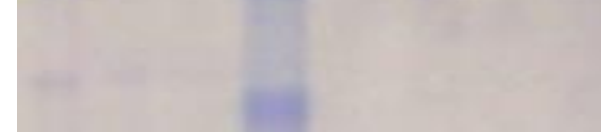

Figure 3.4: Identification of MICA-129Met-Fc, MICA-129Val-Fc and OVA-Fc fusion proteins.

(A) MICA-129Met-mlgG ${ }_{2 a}$-FC and L-MICA-129Val- mlgG $_{2 a}-$ Fc proteins ( $90 \mathrm{kDa}$ ) were separated together with a BSA standard ( $66 \mathrm{kDa})$ of different concentrations and a marker (M) on a SDS-PAGE and stained with 
Coomassie blue (left panel) to demonstrate the integrity of the recombinant fusion proteins. Both fusions proteins $(5 \mu \mathrm{g})$ were separated and blotted. The blot was probed with a biotinylated anti-MICA Ab and subsequently with an anti-mouse IgG Ab (right panel). (B) The OVA- IIgG $_{2 a}-F c$ control ( 70 kDa) was separated with a marker (M) on a SDS-PAGE and stained with Coomassie blue (left panel). The OVA-Fc fusion protein (1 $\mu \mathrm{g})$ was separated together with OVA $(2 \mu \mathrm{g})$ and blotted. The blot was probed with an anti-OVA Ab. (C) Both MICA-129-Fc proteins (which were stored with $0.1 \%$ of the carrier protein BSA before analysis) were partly deglycosylated using a recombinant fusion protein of the endoglycosidase $\mathrm{H}$ (Endo $\mathrm{H}_{\mathrm{f}}, 70 \mathrm{kDa}$ ). SDS-PAGE after Endo $\mathrm{H}_{\mathrm{f}}$ digestion is indicated showing partial deglycosylation of the MICA-129-Fc proteins by this glycosidase (80 kDa).

We used the MICA-129Met-mlgG ${ }_{2 a}-\mathrm{Fc}$ and MICA-129Val-mlgG ${ }_{2 a}-\mathrm{Fc}$ fusion proteins to analyze their binding to the NKG2D receptor of human NK cells. For these experiments, primary human PBMCs were separated by density gradient centrifugation from peripheral blood of voluntary donors and NK cells were isolated by MACS and stimulated with recombinant human IL-2 for 4 days. In parallel to the analysis of the binding of the recombinant MICA-129-Fc proteins to NKG2D of the activated NK cells, NK cells were always characterized and their purity was evaluated by using Abs against the two NK cell markers CD16 and CD56 and the three NK cell receptors CD94, NKp44 (CD336) and NKG2D (CD314) (Figure 3.5). The purity of NK cells, used for all performed experiments, always varied within a range between $95 \%$ and $98 \%$.

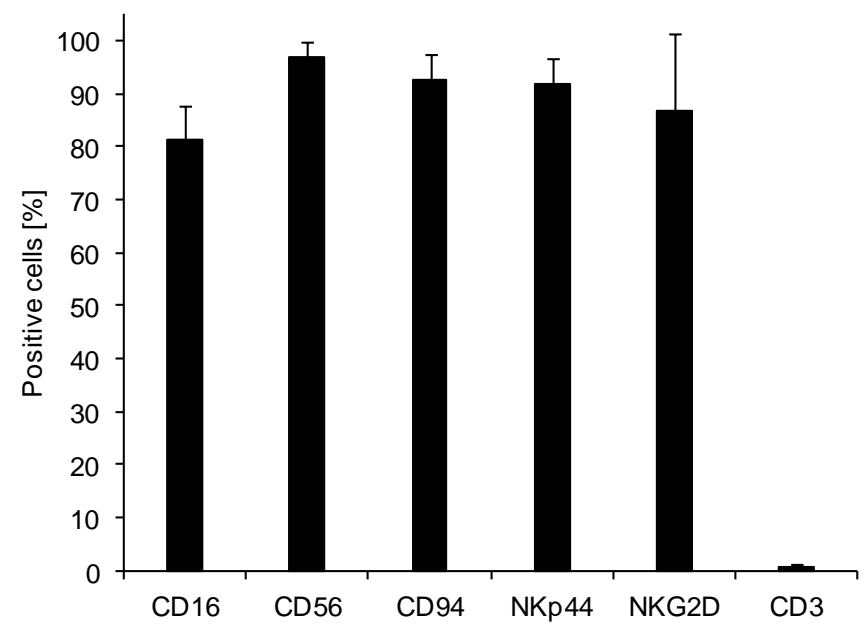

Figure 3.5: Characterization of purified IL-2-stimulated human NK cells.

For NK cell characterization the NK cell markers and receptors CD16, CD56, CD94, NKp44 and NKG2D as well as the $\mathrm{T}$ cell marker CD3 were always determined by flow cytometry on the surface of MACS-isolated human NK cells, stimulated for 4 days with IL-2 $(100 \mathrm{U} / \mathrm{ml})$, before the cells were used in experiments. The means plus SD of the percentage of cells positive for the respective markers are shown $(n \leq 26)$.

Flow cytometric analysis of the binding avidity of the two MICA-129-mlgG $\mathrm{ga}_{2 \mathrm{a}}-\mathrm{Fc}$ proteins and the OVA$\mathrm{mlgG}_{2 \mathrm{a}} \mathrm{Fc}$ negative control to NKG2D of IL-2-stimulated human NK cells revealed that both MICA proteins, in contrast to the OVA protein, bound specifically and concentration-dependent $(P=4.28 \mathrm{x}$ $10^{-9}$, ANOVA) to NK cells (Figure 3.6 A, B). The maximal binding occurred at concentrations of MICA129-Fc fusion proteins between $5 \mu \mathrm{g} / \mathrm{ml}$ and $20 \mu \mathrm{g} / \mathrm{ml}$. In these binding assays, the MICA-129Met protein appeared to bind stronger at lower concentrations, whereas the MICA-129Val protein 
seemed to gain advantages at higher concentrations. Overall there was no statistical significant difference between the MICA-129Met-Fc and MICA-129Val-Fc fusion proteins when the MFI $(P=$ 0.2833 ) or the percentage of MICA-binding NK cells $(P=0.2050)$ were evaluated (ANOVA adjusted for protein concentration).

A

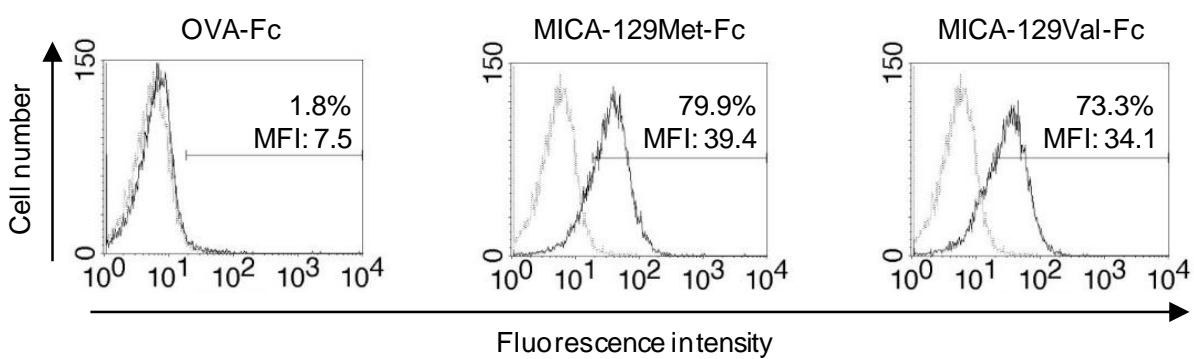

B
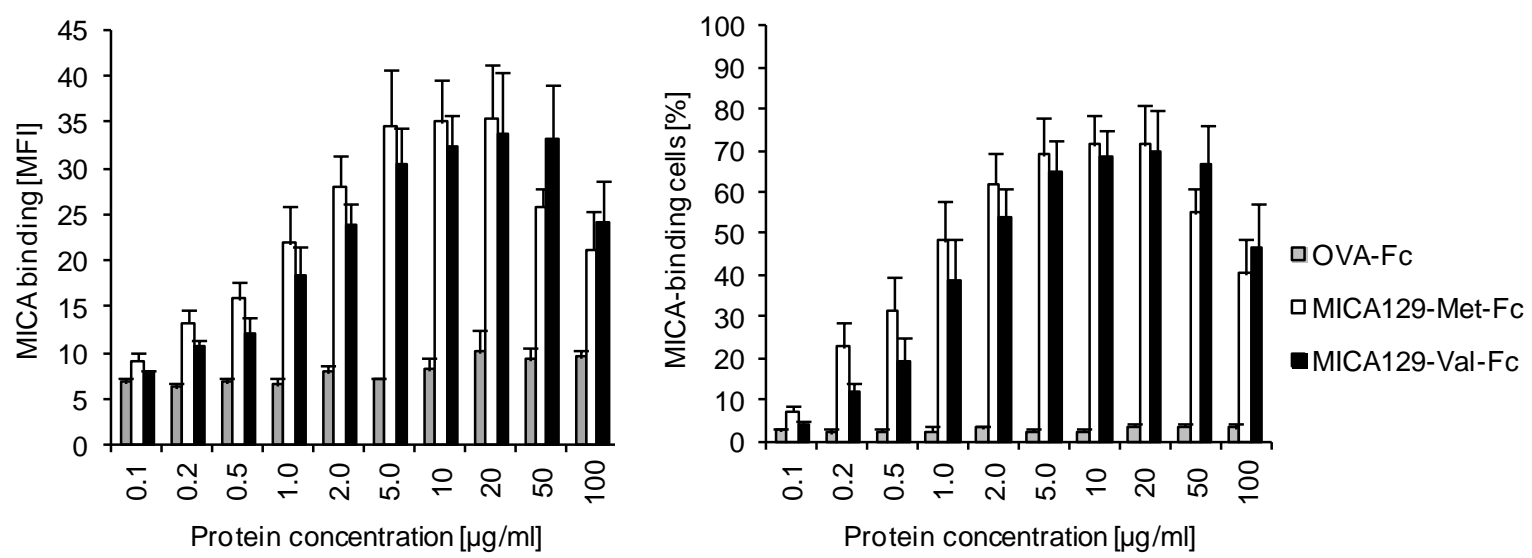

Figure 3.6: MICA-129Met-Fc and MICA-129Val-Fc fusion proteins, but not OVA-Fc protein, bind to NKG2D of human NK cells.

(A) The binding of MICA-129Met-Fc, MICA-129Val-Fc and as negative control OVA-Fc fusion proteins to IL-2stimulated ( $100 \mathrm{U} / \mathrm{ml}$ for 4 days) purified NK cells was determined by flow cytometry. The histograms show the staining with the fusion proteins $(10 \mu \mathrm{g} / \mathrm{ml})$ plus secondary FITC-labeled $\mathrm{Ab}$ in bold and with the secondary Ab only in light. The percentage of cells binding to the proteins and the MFI is indicated. The percentage of cells stained with the secondary $\mathrm{Ab}$ only was $1.1 \%$ in the range of the marker and the MFI was 5.9. (B) The binding of MICA-129Met-Fc, MICA-129-Val-Fc and OVA-Fc fusion proteins to NK cells was determined by flow cytometry at various concentrations and is shown as mean $(n \geq 3)$ and SD of the MFI (left panel) and the percentage of positive cells (right panel).

Moreover, the binding avidity of the two recombinant MICA-129-Fc fusion proteins to the recombinant human NKG2D-Fc fusion protein was determined in four experiments by SPR analysis. Therefore, the NKG2D-Fc protein was covalently immobilized on an activated 2D SPR sensorchip and the SPR response was recorded after injection of nine different MICA-129Met-Fc and MICA-129Val-Fc protein concentrations between $2 \mathrm{nM}$ and $500 \mathrm{nM}$ (Figure 3.7 A-C). However, the statistical analysis 
showed that the two MICA-129-Fc proteins did not significantly differ in their binding to NKG2D $(P=$ $0.1449, \mathrm{t}$ test) (Figure $3.7 \mathrm{D}$ ). Conceivably a tendency towards a higher NKG2D binding avidity of the MICA-129Met isoform might be apparent.

A

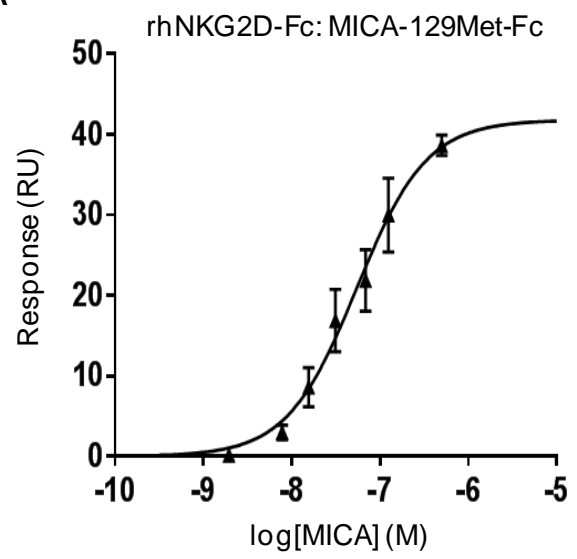

C

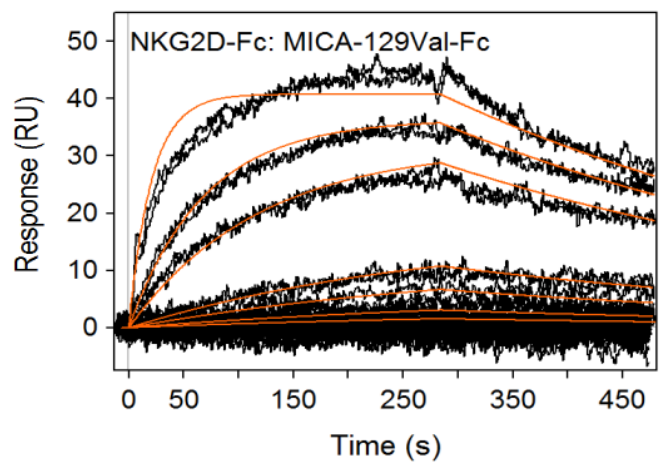

B

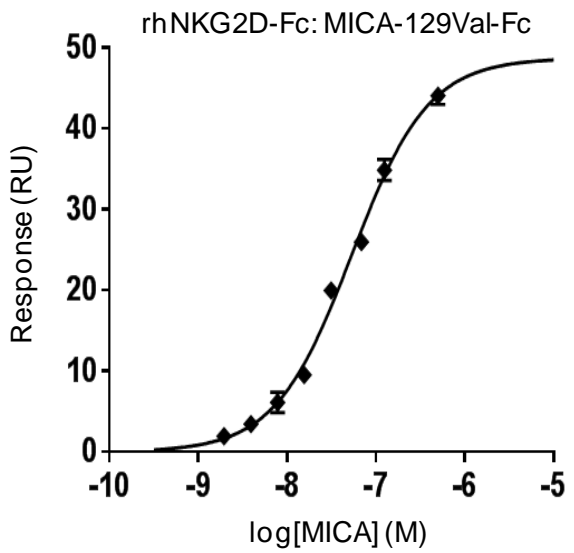

D

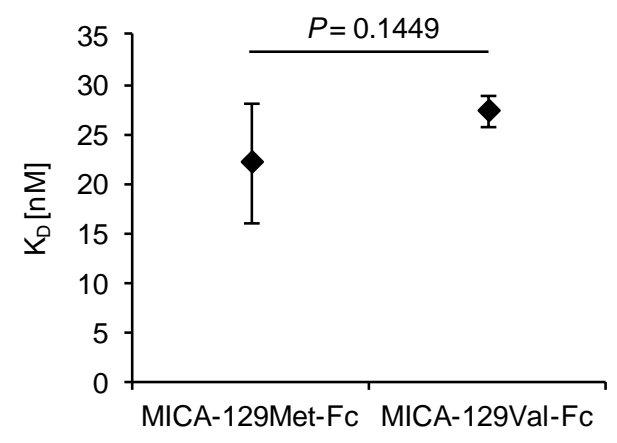

Figure 3.7: MICA-129Met-Fc and MICA-129Val-Fc proteins bind with similar avidity to NKG2D-Fc in SPR analysis.

NKG2D-Fc was covalently immobilized on an activated HC 1000m SPR sensorchip and the SPR response was recorded after injecting 2, 4, 8, 16, 32, 64, 125, 250 and $500 \mathrm{nM}$ of MICA-129Met-Fc and MICA-129Val-Fc fusion proteins. (A) Equilibrium binding analysis of NKG2D-Fc binding to MICA-129Met-Fc and (B) MICA-129Val-Fc fusion proteins at $20^{\circ} \mathrm{C}$ is shown. The equilibrium binding constants $\left(K_{D}\right)$ of the MICA-129Met-FC and MICA$129 \mathrm{Val}-\mathrm{Fc}$ proteins were obtained using a non-linear curve fit. (C) A typical sensogram of MICA-129Val-Fc binding obtained via SPR analysis is depicted showing the observed binding as black lines. Solid red lines show the global fit of SPR data using kinetic parameters $k_{a}$ and $k_{d}$. (D) The results of NKG2D binding for the MICA$129 \mathrm{Met}-\mathrm{Fc}$ and L-MICA-129Val-Fc isoforms of four experiments $(n=4)$ are summarized (means \pm SD) and compared by an unpaired $t$ test. 


\subsection{Functional effects of the MICA-129 dimorphism on human NK cells}

Next, we addressed the question whether the MICA-129Met/Val polymorphism has an impact on NKG2D-mediated signaling as well as on functional effects of human NK cells including cytotoxicity and cytokine production.

\subsubsection{Impact of the MICA-129 dimorphism on NKG2D-mediated signaling}

To determine differences in NKG2D-mediated signaling events, the recombinant MICA-129-mlgG ${ }_{2 a}-F c$ fusion proteins and as negative control also the OVA-mlgG ${ }_{2 a}-F c$ fusion protein were immobilized at a concentration of $10 \mu \mathrm{g} / \mathrm{ml}$ in microtiter plates and purified IL-2-stimulated human NK cells were added. Binding of both MICA-129 proteins to NK cells was similar at this concentration (see section 3.2.2, Figure $3.6 \mathrm{~A}, \mathrm{~B}$ ). The NK cells were harvested after $3 \mathrm{~min}, 10 \mathrm{~min}$ and $30 \mathrm{~min}$ and protein lysates were obtained. Probing of western blots with an anti-phospho-tyrosine mAb and an antiphospho-Src family kinases (Tyr419 or Tyr416 when following the original nomenclature from chicken) Ab indicated stronger (Figure $3.8 \mathrm{~A}$ ) and earlier phosphorylation of Src kinases in NK cells triggered by the MICA-129Met compared to the MICA-129Val isoform (Figure 3.8 B and see Appendix, Figure A.1). However, no clear differences in the phosphorylation of further downstream signaling molecules such as the guanine nucleotide exchange factor VAV1 (Tyr174) and the Src homology 2 (SH2) domain-containing leukocyte protein of $76 \mathrm{kDa}$ (SLP-76) (Tyr128) were recognizable (Figure 3.8 B, right panel and see Appendix, Figure A.1). Probing of several blots with further phospho-specific antibodies for the phospholipase C- $\gamma 2$ (PLC- $\gamma 2$ ) (Tyr759), the p85 (Tyr458)/p55 (Tyr199) subunits of phosphatidylinositol 3-kinase (PI3K), the protein kinase Akt (Ser473) and the spleen tyrosine kinase Syk (Tyr352), along with $\zeta$-chain-associated protein of $70 \mathrm{kDa}$ (ZAP-70) tyrosine kinase (Tyr319), showed no or only weak signals (data not shown). Taken all together, we found that the MICA-129Met variant triggers a faster and stronger phosphorylation of Src family kinases in human NK cells than the MICA-129Val variant. 
A

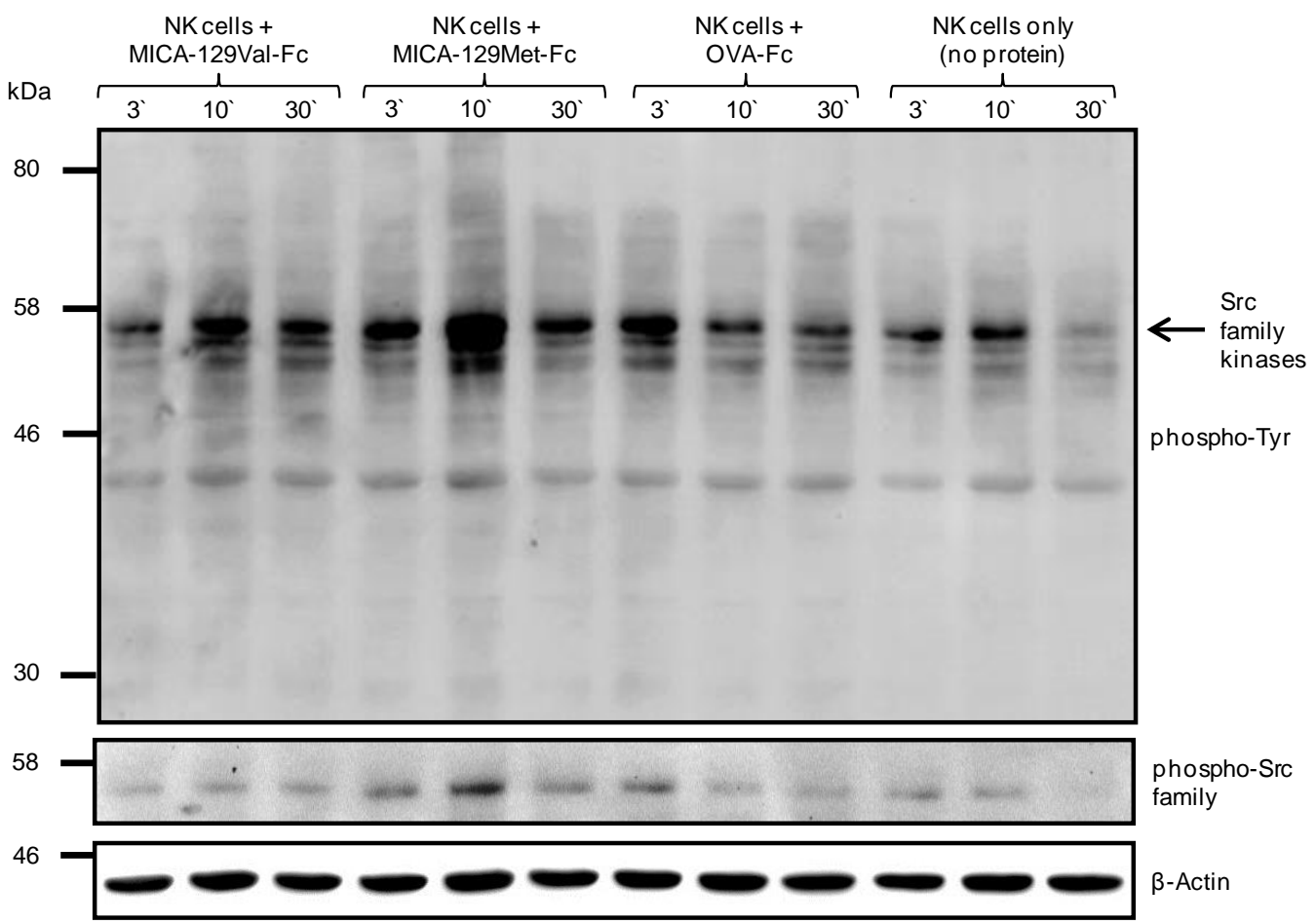

\section{B}
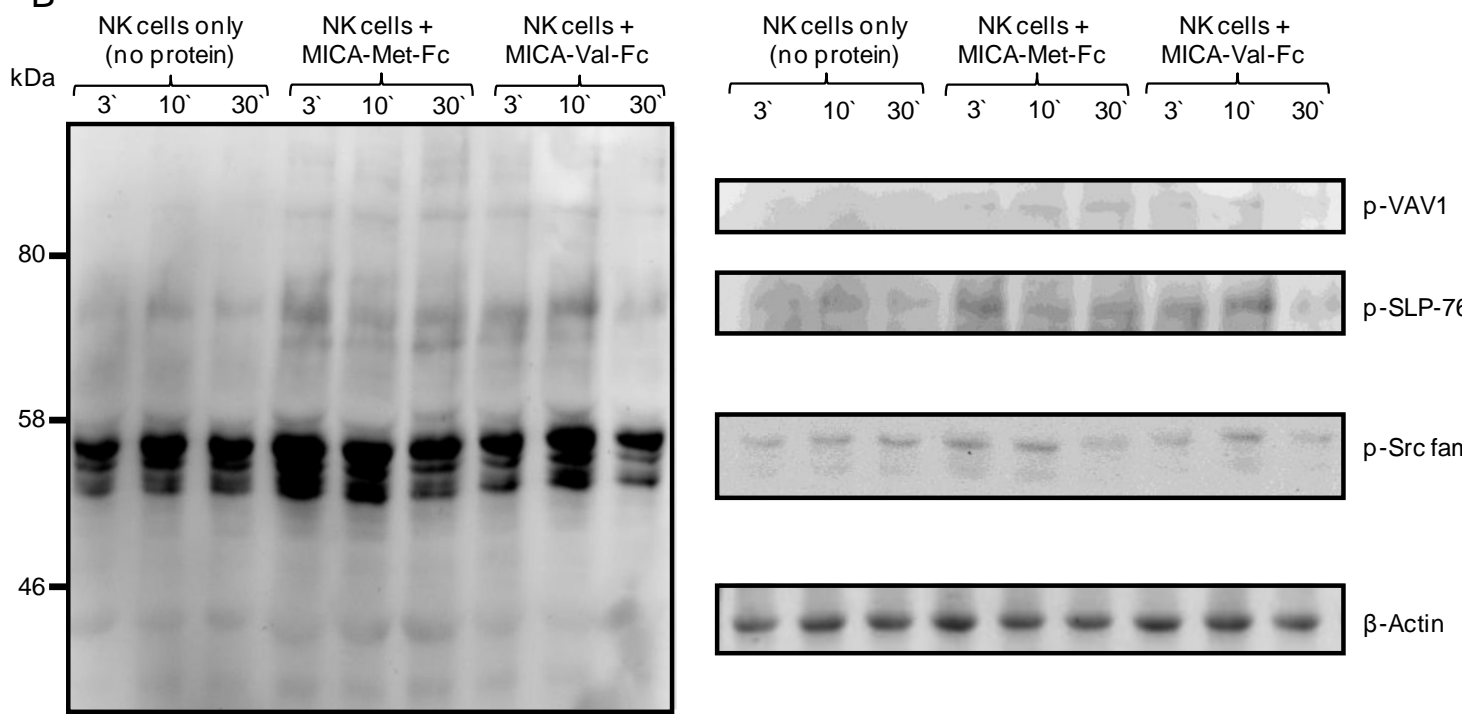

p-Src family

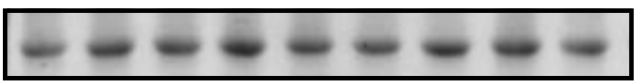

$\beta$-Actin

Figure 3.8: NKG2D-mediated phosphorylation of Src family kinases in response to the MICA-129Met-Fc protein is stronger and faster than in response to the MICA-129Val-Fc protein.

(A) Purified IL-2-stimulated (100 U/ml for 4 days) human NK cells $\left(10^{6}\right)$ were stimulated with immobilized MICA$129 \mathrm{Met} / \mathrm{Val}-\mathrm{mlgG}_{2 \mathrm{a}}$-Fc or OVA-mlgG ${ }_{2 a}$-Fc fusion proteins $(10 \mu \mathrm{g} / \mathrm{ml})$ for 3, 10 or $30 \mathrm{~min}$ in microtiter plates. The protein lysates of these cells were separated by SDS-PAGE and the blot was probed with an anti-phospho-Tyr mAb (upper panel), an anti phospho-Src family kinases (Tyr419) Ab and an anti- $\beta$-Actin mAb as loading control. (B) NK cells were stimulated as described above with the two MICA-129-Fc isoforms and the resulting blot was probed with an anti-phospho-Tyr mAb (left panel). After stripping of the blot membrane with $\beta$ mercaptoethanol-containing buffer, the blot was probed with different anti-phospho-specific Abs (antiphospho-VAV1 (Tyr174), anti-phospho-SLP-76 (Tyr128) and anti-phospho-Src family kinases (Tyr419) Ab) and an anti- $\beta$-Actin $\mathrm{mAb}$. 
To test whether the phosphorylation of Src family kinases is a relevant step in NKG2D signaling of NK cells when triggered by MICA, the Src family kinases inhibitor PP2 was used. In these experiments, $10^{6}$ IL-2-stimulated NK cells were incubated with the PP2 inhibitor $(25 \mu \mathrm{M})$, the vehicle dimethyl sulfoxide (DMSO) or medium only for 30 min before being added to immobilized MICA-129Met$\mathrm{mlgG}_{2 \mathrm{a}}-\mathrm{Fc}$, MICA-129Val-mlgG ${ }_{2 a}-\mathrm{Fc}$ or OVA-mlgG ${ }_{2 a}-\mathrm{Fc}$ fusion proteins $(10 \mu \mathrm{g} / \mathrm{ml})$ for $10 \mathrm{~min}$. After PP2 treatment of NK cells, indeed no phosphorylation of Src family kinases in NK cells stimulated with the OVA-Fc, MICA-129Met-Fc and MICA-129Val-Fc proteins was apparent as shown by western blot analysis using an anti-phospho-tyrosine mAb and an anti-phospho-Src family kinases (Tyr419) Ab (Figure $3.9 \mathrm{~A}$ ).

A

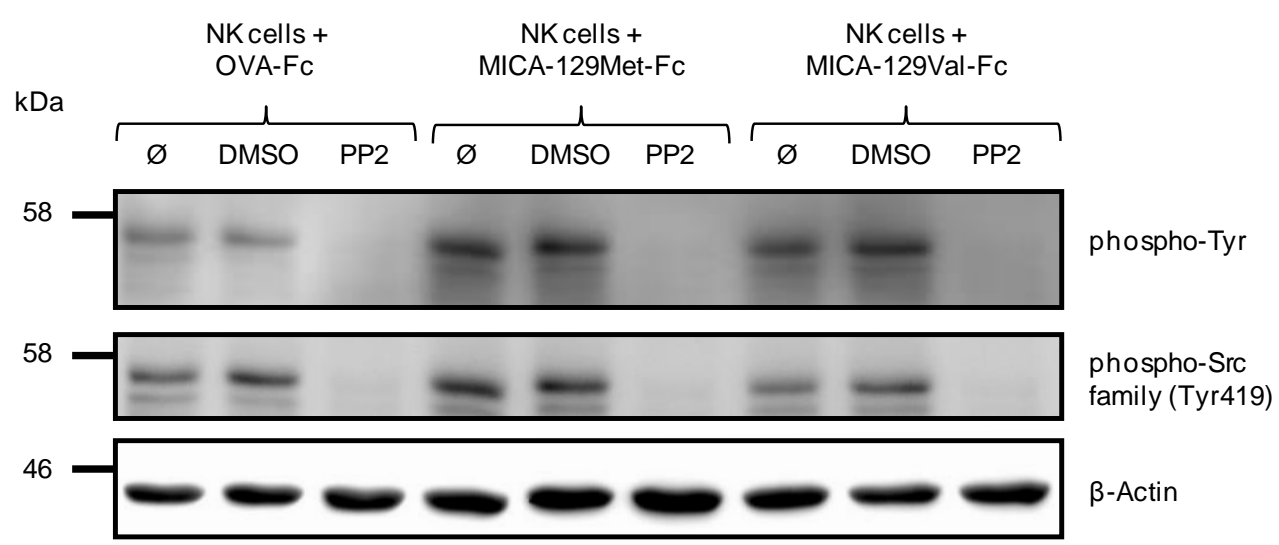

B

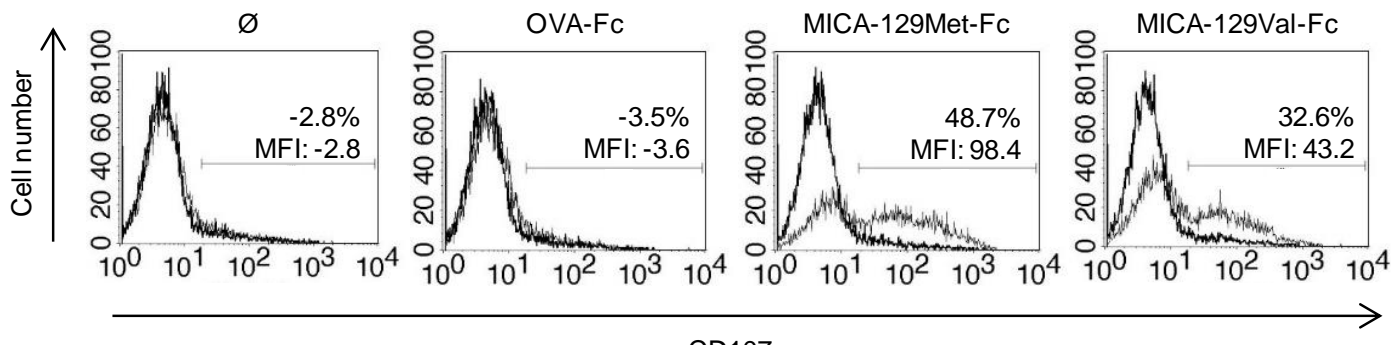

CD107a

Figure 3.9: The specific inhibitor PP2 inhibits phosphorylation of Src family kinases in response to the MICA129Met-Fc and MICA-129Val-Fc proteins.

(A) Purified human NK cells $\left(10^{6}\right)$, stimulated for 4 days with $100 \mathrm{U} / \mathrm{ml} \mathrm{IL-2,} \mathrm{were} \mathrm{incubated} \mathrm{with} \mathrm{the} \mathrm{Src} \mathrm{family}$ kinases inhibitor PP2 $(25 \mu \mathrm{M})$, the vehicle dimethyl sulfoxide (DMSO) or medium only $(\varnothing)$ for 30 min before being added to immobilized MICA-129Met/Val-mlgG $2 a-F c$ or OVA-mlgG $2 a-F c$ fusion proteins (10 $\mu \mathrm{g} / \mathrm{ml})$ for 10 min. The protein lysates of these cells were separated by SDS-PAGE and the blot was probed with an antiphospho-Tyr mAb (upper panel), an anti phospho-Src family kinases (Tyr419) Ab and an anti- $\beta$-Actin mAb as loading control. The blot is representative for two independent experiments. (B) The NK cells were incubated with the Src family kinases inhibitor PP2 $(25 \mu \mathrm{M})$ or the vehicle DMSO for $30 \mathrm{~min}$ before being added to immobilized MICA-129Met/Val-mlgG ${ }_{2 a}-F c$ or OVA-mlgG ${ }_{2 a}-F c$ fusion proteins $(10 \mu \mathrm{g} / \mathrm{ml})$ or medium only $(\varnothing)$ for $1 \mathrm{~h}$. Degranulation of the NK cells was measured by anti-CD107a staining in flow cytometry. Bold lines represent NK cells treated with PP2 and thin lines those treated with DMSO. The difference between DMSO and PP2-treated cells with respect to CD107a-positive cells and the MFI of CD107a is indicated in the histograms. The results are representative for two independent experiments. 
In parallel, degranulation of NK cells after treatment with the Src family kinases inhibitor PP2 was measured by anti-CD107a staining in flow cytometry. Therefore, human IL-2-stimulated NK cells were incubated with PP2 (25 $\mu \mathrm{M})$ for 30 min before being added to immobilized MICA-129Met-Fc, MICA129Val-Fc or OVA-Fc fusion proteins $(10 \mu \mathrm{g} / \mathrm{ml})$ or for comparison to medium only for $1 \mathrm{~h}$. CD107a cell surface expression assays revealed that the NKG2D-triggered degranulation of NK cells after PP2 inhibition was completely abolished (Figure 3.9 B) indicating a functional relevance of the observed differences in the strength and kinetics of phosphorylation of Src family kinases triggered by the two MICA-129 variants. Notably, the MICA-129Met variant induced more CD107a expression compared to the MICA-129Val variant in these experiments.

\subsubsection{Influence of the MICA-129 dimorphism on NK cell cytotoxicity}

\subsubsection{Degranulation of NK cells after stimulation with MICA-129-Fc proteins}

To analyze the degranulation of human IL-2-activated NK cells stimulated with either MICA-129MetFc or MICA-129Val-Fc fusion proteins in detail, more CD107a expression assays were performed. Granule exocytosis of NK cells leads to expression of the degranulation marker CD107a at the NK cell surface. In contrast to unstimulated NK cells, NK cells exposed to immobilized MICA-129Met-Fc or MICA-129Val-Fc proteins showed CD107a expression (Figure 3.10 A) confirming the functional activity of these proteins. The NK cell degranulation elicited by both MICA-129-Fc proteins (and the OVA-Fc protein as negative control) was compared over a broad range of protein concentrations as depicted in Figure 3.10 B. The statistical analysis revealed that the MICA-129-Met variant indeed triggered more degranulation than the MICA-129Val variant when the MFI of CD107a expression ( $P=$ 0.0011 , ANOVA adjusted for protein concentration) or the percentage of CD107a-positive NK cells ( $P$ $=0.0003$, ANOVA adjusted for protein concentration) was evaluated (Figure $3.10 \mathrm{~B}$ ).

In summary, the MICA-129Met variant seems to be a stronger trigger of NK cell-mediated granule exocytosis than the MICA-129Val variant. This finding furthermore argued for a functional relevance of the observed differences in the strength and kinetics of phosphorylation of Src family kinases elicited by the two MICA-129 variants (see section 3.3.1, Figure 3.9). 
A

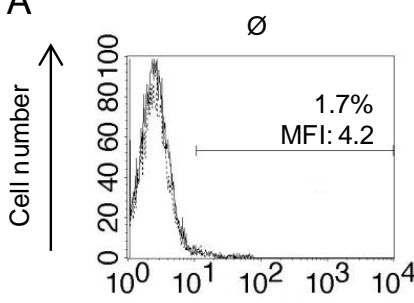

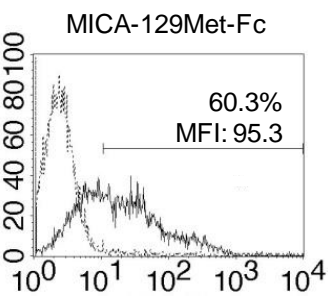

CD107a
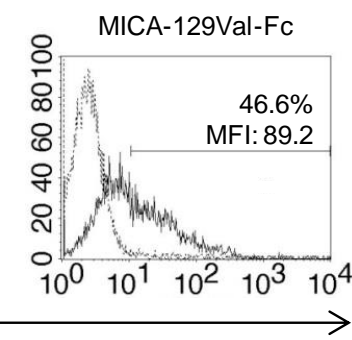

B
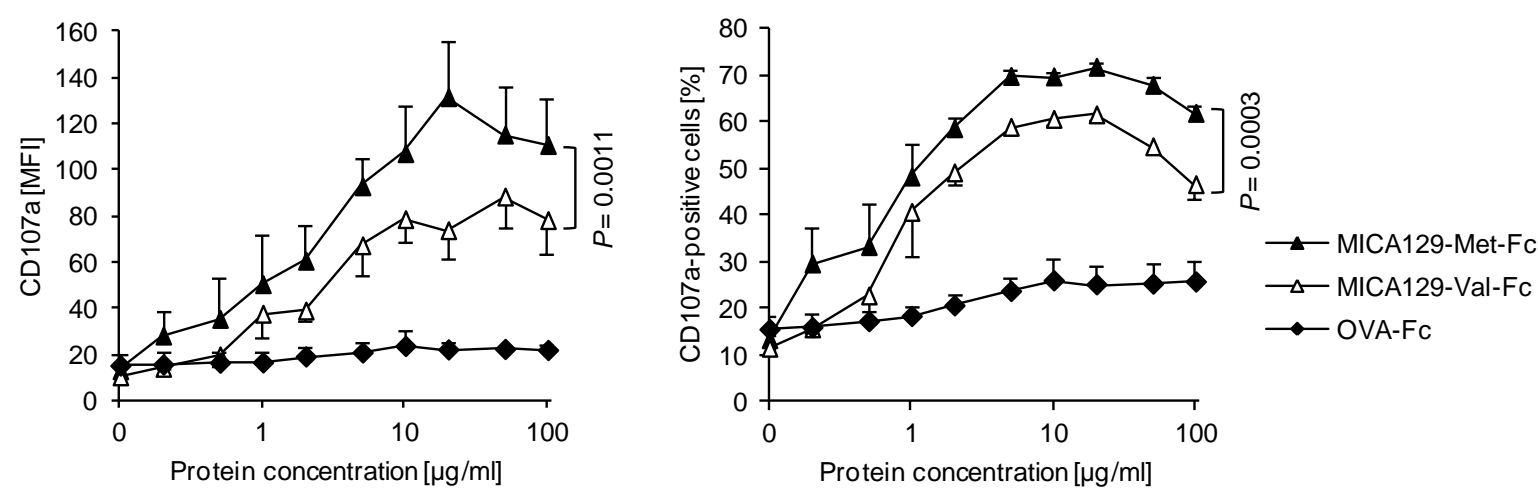

Figure 3.10: Degranulation of NK cells differs after stimulation with MICA-129Met-Fc and MICA-129Val-Fc proteins.

(A) The degranulation of purified IL-2-stimulated (100 U/ml for 4 days) human NK cells in response to immobilized MICA-129Met-Fc and MICA-129-Val-Fc fusion proteins $(5 \mu \mathrm{g} / \mathrm{ml})$ was determined by flow cytometry performing CD107a expression assays. Representative figures of an experiment are depicted. (B) Granule exocytosis is shown as mean $(n \geq 3)$ and standard deviation (SD) of the MFI (left panel) and the percentage of positive cells (right panel). MICA-129Met-Fc, MICA-129-Val-Fc and as negative control OVA-Fc fusion proteins were immobilized at various concentrations in microtiter plates before the NK cells were added for $1 \mathrm{~h}$.

\subsubsection{Degranulation of NK cells after co-culture with L-MICA-129 targets}

To investigate the effects of the MICA-129 dimorphism on degranulation of IL-2-activated human NK cells in a more physiological context, CD107a expression on NK cells exposed to MICA-129Met or MICA-129Val-expressing $L$ target cells was determined. For the experiments human PBMCs were stimulated for 4 days with $\mathrm{IL}-2(100 \mathrm{U} / \mathrm{ml})$ and then characterized by flow cytometry for the expression of the NK cell surface markers CD16 and CD56 and the NK cell receptors CD94, NKp30 (CD337), NKp44 (CD336), NKp46 (CD335) and NKG2D (CD314). In addition, also the percentage of cells positive for the $T$ cell marker CD3 and the $\gamma \delta$ T cell receptor (TCR), the B cell marker CD19 and the monocyte/macrophage marker CD14 was measured (Figure 3.11 A). For flow cytometric analysis of CD107a expression, NK cells among PBMCs were identified by staining of CD16 and CD56. The 
CD56-positive NK cells were gated as shown in Figure 3.11 B and degranulation of these NK cells exposed to L-con, L-MICA-129Met and L-MICA-129Val cells for $1 \mathrm{~h}$ was analyzed after additional staining of CD107a. While NK cells exposed to L-con cells exhibited only slight CD107a expression, NK cells attacking MICA-Met or MICA-Val-expressing cells showed increased granule exocytosis (Figure 3.11 C). In parallel to each degranulation assay, the MICA expression intensity of the target cells was determined. Statistical analysis revealed that degranulation of NK cells in response to L-MICA129Met and L-MICA-129Val cells was depended on the MICA expression intensity and significantly different between targets expressing the two MICA-129 variants. With adjustment for MICA expression intensity, less NK cells exposed to MICA-129Val-expressing target cells were CD107apositive $(-10.08 \%, P=0.0456$, ANOVA) compared to NK cells attacking MICA-129Met-expressing targets (Figure $3.11 \mathrm{E}$ ). Also the MFI of CD107a was lower on NK cells exposed to L-MICA-129Val targets $(-38.45 \%, P=0.0174)$ (Figure $3.11 \mathrm{D})$. Notably, for NK cells recognizing the MICA-129Val variant, granule exocytosis significantly increased with MICA expression intensity (MFI of CD107a, slope $0.286, P=0.0279)$, in contrast to NK cells exposed to the MICA129-Met variant $(P=0.4964)$. Thus, the MICA-129Met variant is overall a stronger trigger of NK cell cytotoxicity than the MICA129Val variant but the MICA129Val variant gains advantages at high MICA expression intensities on target cells. 
A

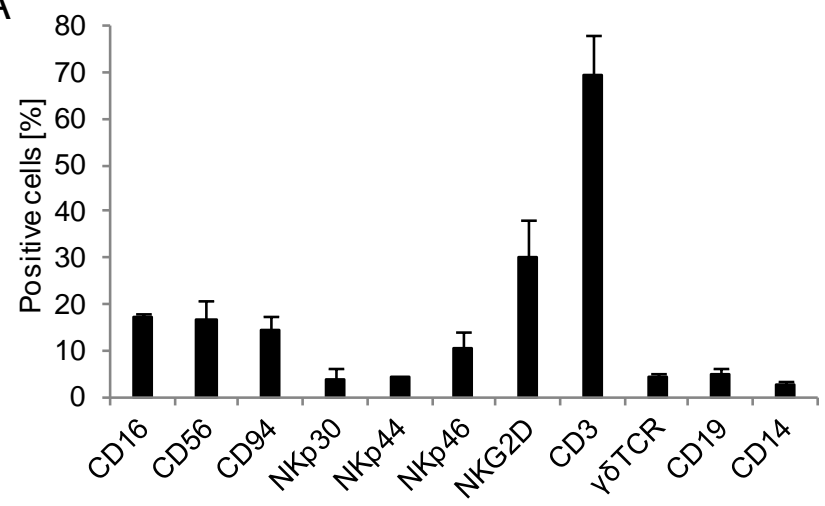

B

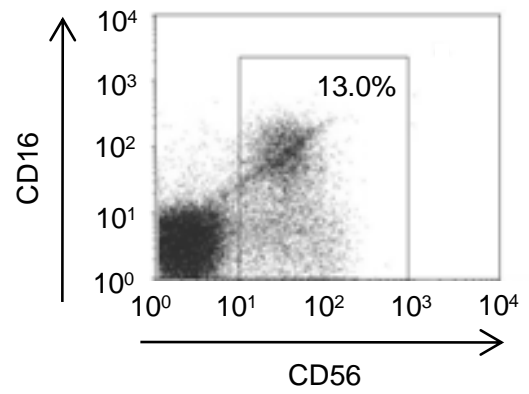

C

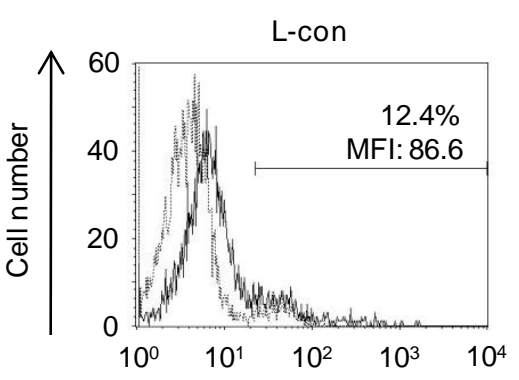

L-MICA-129Met

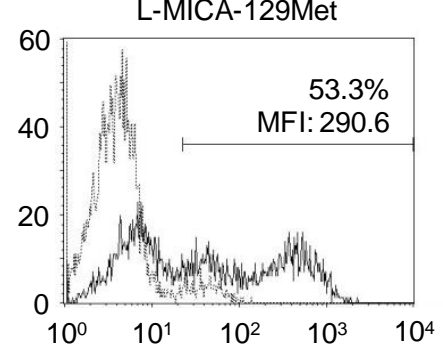

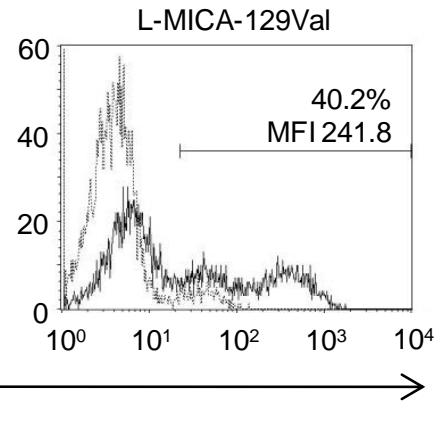

L-MICA-129Val

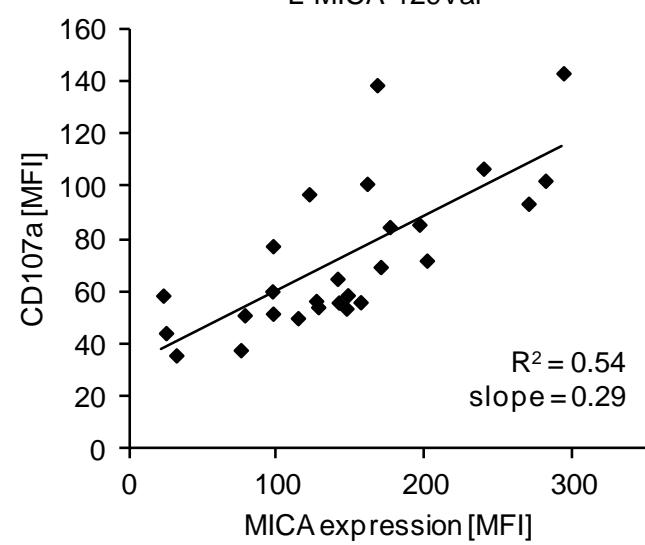

L-MICA-129Val

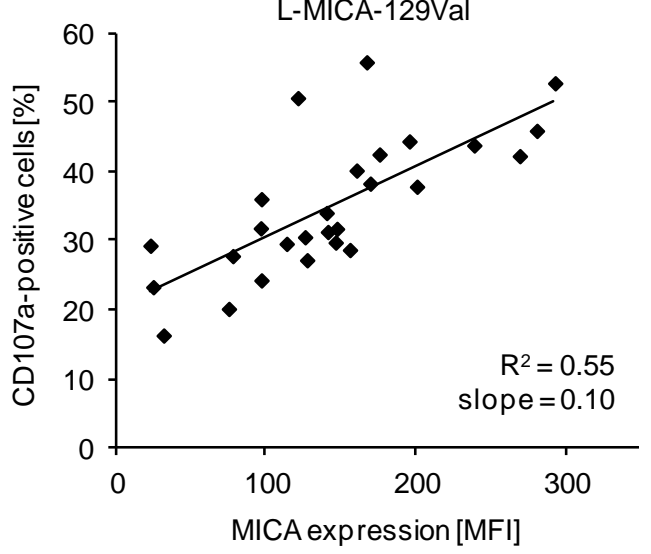


Figure 3.11: Granule exocytosis of NK cells exposed to MICA-129Met and MICA-129Val-expressing $L$ cells is significantly different and depends on the MICA expression level.

(A) Human PBMCs were stimulated in vitro for 4 days with IL-2 $(100 \mathrm{U} / \mathrm{ml})$ and then characterized by flow cytometry for expression of the indicated cell surface markers. The percentage of cells positive for various markers (mean $+S D, n>3$ ) is shown. (B) NK cells among PBMCs were identified by staining of CD16 and CD56. The $\mathrm{CD}_{56}{ }^{+} \mathrm{NK}$ cells were gated as shown in this dot plot for subsequent analysis of CD107a expression. (C) The degranulation of $\mathrm{CD}_{56}{ }^{+} \mathrm{NK}$ cells exposed to L-con, L-MICA-129Met or L-MICA-129Val cells for $1 \mathrm{~h}$ was determined by flow cytometry after staining of CD107a. Black lines indicate CD107a staining, while gray-lined histograms show the isotype control. The percentages of $\mathrm{CD}_{107 a^{+}}$cells and the MFI of CD107a of these measurements are indicated in the histograms. (D) CD107a cell surface expression of NK cells exposed to LMICA-129Met $(n=27)$ or L-MICA-129Val cells $(n=27)$ was analyzed. In parallel, the MICA expression on target cells was determined. The linear regression of CD107a on NK cells and MICA expression on targets, both determined as MFI, is shown for the L-MICA-129Met (left panel) and L-MICA-129Val cells (right panel). The coefficient of determination $\left(R^{2}\right)$ and the slope of the regression line are indicated for both MICA variants. (E) The CD107a expression on NK cells was also analyzed with respect to the percentage of CD107a ${ }^{+}$cells. The linear regression of $\mathrm{CD}_{107 \mathrm{a}^{+}} \mathrm{NK}$ cells and MICA expression on targets (MFI) is shown for the L-MICA-129Met (left panel) and L-MICA-129Val cells (right panel).

\subsubsection{Susceptibility of MICA-129-expressing targets to NK cell-mediated killing}

To further establish the functional relevance of the MICA-129 dimorphism for killing of target cells, the susceptibility of the two L-MICA-129 variants to killing by IL-2-stimulated human LAK and MACSisolated NK cells was analyzed using Chromium-51 $\left({ }^{51} \mathrm{Cr}\right)$ release assays. A representative experiment is depicted in Figure 3.12. A showing the specific cell lysis of MICA-negative L-con cells and one clone of MICA-129Met and MICA-129Val-expressing $L$ cells by LAK cells at different effector to target (E:T) ratios. K562 cells, which are known to be highly susceptible to killing by human NK cells, were included as positive control. The results demonstrate that MICA-expressing cells were effectively killed by human LAK cells in contrast to the vector-only transfected L-con cells, which were largely resistant to killing indicating that the lysis of the MICA-positive $L$ transfectants was MICA-dependent. The MICA expression intensity on the target cells as well as the binding of a recombinant NKG2D-FC protein was always determined in parallel to the cytotoxicity assays (Figure $3.12 \mathrm{~A}$, box). In this experiment, the L-MICA-Met clone exhibited besides an increased NKG2D binding also an increased specific cell lysis compared to the MICA-Val clone, which however expressed more MICA. 
A

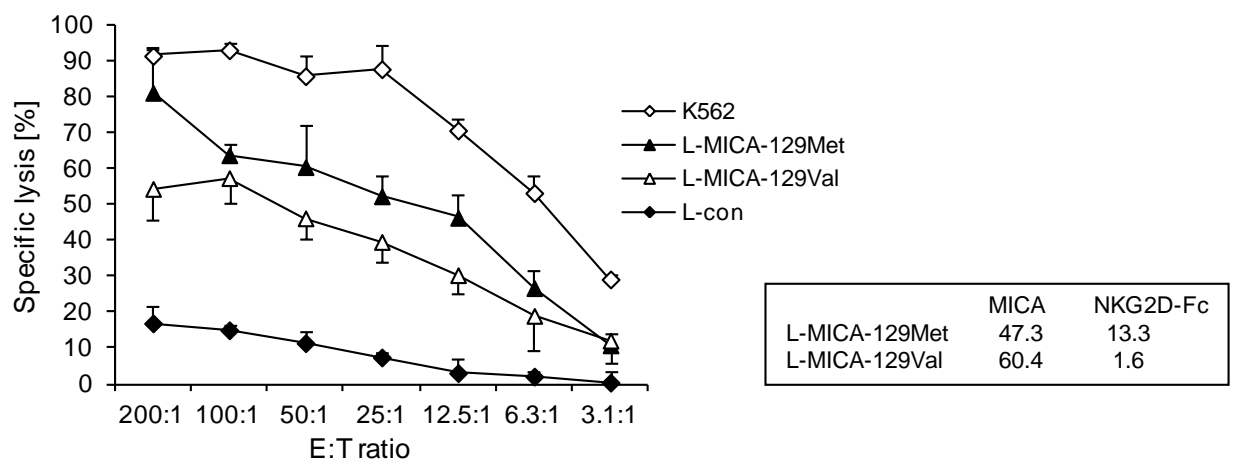

B

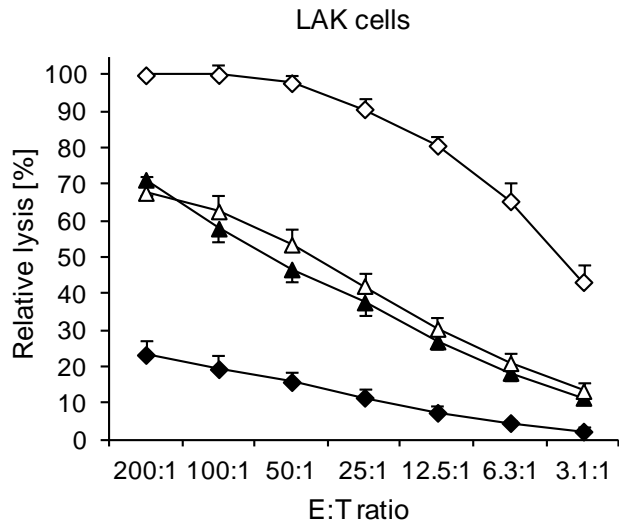

C

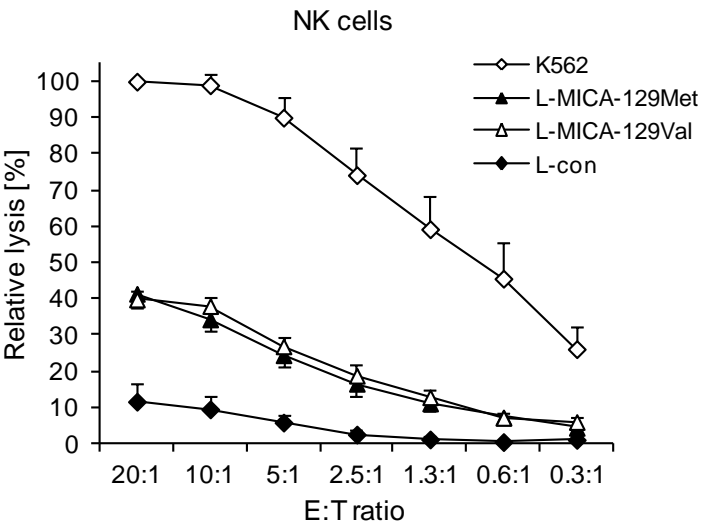

D

Lower MICA expression quartile

Upper MICA expression quartile
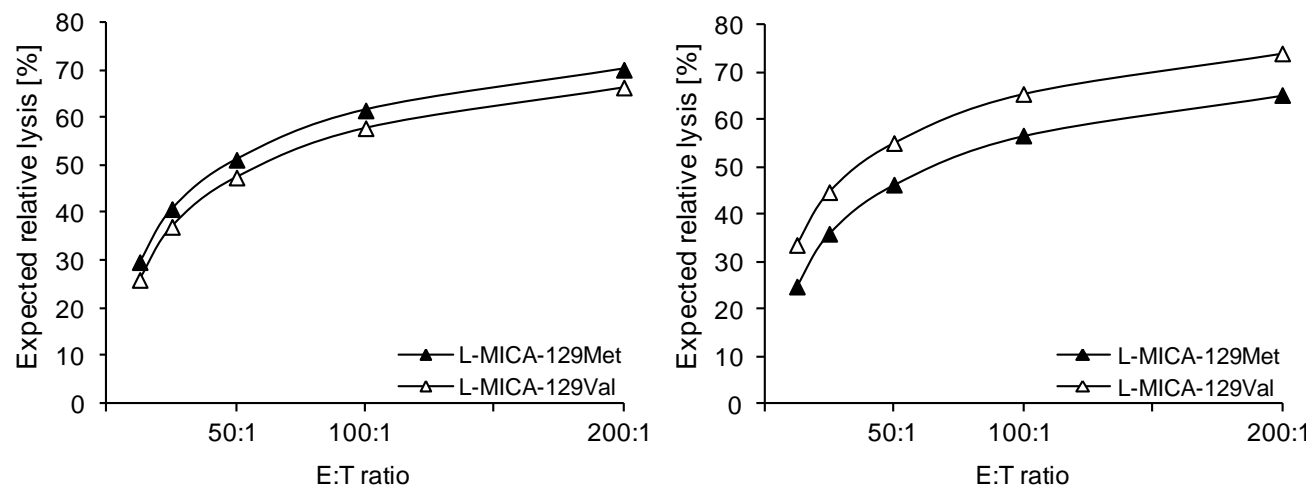

Figure 3.12: Cytotoxicity of NK cells in response to the MICA-129Met and MICA-129Val isoforms significantly varies and depends on the MICA expression intensity.

(A) A representative experiment is shown demonstrating the specific cytotoxic activity of human LAK cells stimulated for 4 days with IL-2 $(100 \mathrm{U} / \mathrm{ml})$ against L-MICA-129Met, L-MICA-129Val and L-con cells as negative control. K562 cells were included as positive control. The means of specific lysis of triplicates \pm standard deviation (SD) at different effector:target (E:T) ratios (200:1 to 3:1) are shown as measured in a ${ }^{51} \mathrm{Cr}$ release assay. The MICA expression intensity and binding of a recombinant NKG2D-Fc fusion protein to the target cells was always determined in parallel by flow cytometry and the MFIs for the experiment shown here are indicated in the box. This individual experiment is included in the summary shown in panel B and D. (B) The mean of relative lysis \pm SD of the before mentioned target cells by IL-2-stimulated LAK cells was determined in 9 independent experiments using 10 different clones of each MICA-129 variant $(n=84)$. (C) The mean of 
relative lysis \pm SD of target cells by MACS-isolated IL-2-activated NK cells was determined in 3 independent experiments using 6 different clones of each MICA-129 variant $(n \geq 11)$. The percentage of specific lysis of K562 cells at the highest E:T ratio (200:1 for LAK cells or 20:1 for NK cells) was adjusted to 100\% in each test and the relative lysis of the target cells by various effector cells at different E:T ratios was calculated. (D) Based on a linear statistical model, the MICA expression intensity was integrated in the calculation of the expected relative lysis of the target cells expressing the MICA-129Met or Val variant by LAK cells at different E:T ratios for the lower and upper MICA expression quartile (MFI: 43.92 or 40.45 and 94.23 or 102.12 for the MICA-129Met or MICA-129Val variant, respectively).

For determination of the relative cell lysis, killing of K562 cells at an E:T ratio of 200:1 was set to $100 \%$ in every experiment and used to calculate the relative lysis of the other targets as depicted in Figure 3.12 B. This graphical representation, which does not include the MICA expression of the target cells, showed no difference in lysis between the two MICA variants for all performed experiments using LAK cells as effectors. However, with adjustment to the MICA expression intensity, the statistical analysis revealed that the relative lysis of the MICA-129Val variant expressing L cells was significantly reduced compared to cells expressing the Met variant $(n=84, P=0.0044$, ANOVA, $-13.0 \%$ at an E:T ratio of 200:1). Importantly, the MICA expression intensity had even a negative influence on killing for targets expressing the MICA-129Met variant, $(P=0.0083$, ANOVA, regression coefficient slope -0.0834,$)$. In contrast, killing increased with expression intensity of the MICA-129Val variant on target cells (slope $0.1257, P<0.0001$ ). Based on a linear statistical model adjusted for the MICA expression intensity, Figure 3.12 D depicts the expected relative cell lysis of MICA-129Met/Valexpressing target cells with low or high expression levels (lower MICA expression quartile with a MFI of 43.92 or 40.45 and upper MICA expression quartile with a MFI of 94.23 or 102.12 for the MICA129Met or MICA-129Val variant, respectively). These data show that high MICA expression intensities are associated with lower killing of cells expressing the MICA-129Met than MICA-129Val variant.

Instead of using human LAK cells, containing between $10 \%$ to $15 \%$ NK cells, we also used purified IL2-stimulated NK cells comprising $95 \%$ to $98 \%$ of NK cells (Figure $3.12 \mathrm{C}$ ). Similar results were obtained with isolated NK cells but with reduced values for the relative cell lysis of MICA-expressing $L$ targets and L-con cells suggesting a better activation of NK cells by IL-2 in a co-culture with other PBMCs or an involvement of a further cell population. Since $\gamma \delta$ T cells also express NKG2D on their cell surface and do not necessarily need additional stimulation of other activating receptors to be activated (Girardi et al., 2001; Whang et al., 2009), this type of T cells might be also involved in killing of the target cells.

In summary, the MICA-129Met variant elicited stronger NK cell cytotoxicity at lower MICA expression intensities compared to the MICA-129Val variant. Notably, cytotoxic effector function increased with the MICA expression intensity of the MICA-129Val variant, whereas high expression of the MICA- 
129Met variant even decreased cytotoxic activity of NK cells. Thus, the Met variant is overall a stronger trigger of NK cell cytotoxicity but the Val variant gains advantages at high MICA expression intensities on target cells.

\subsubsection{Effect of the MICA-129 dimorphism on IFN- $p$ release}

Besides target cell killing we also analyzed IFN- $\gamma$ release, which is a further effector function of NK cells triggered by NKG2D stimulation. The IFN- $\gamma$ release in the supernatant of purified human IL-2stimulated NK cells co-cultured with L-con or MICA-129Met or Val-expressing L target cells for $24 \mathrm{~h}$ was determined by an ELISA detecting IFN- $\gamma$ and the MICA expression of the target cells was measured in parallel by flow cytometry. Statistical analysis of the data adjusted to MICA expression intensity revealed that IFN- $\gamma$ production was significantly higher for NK cells exposed to L-MICA129 Met compared to L-MICA-129Val cells $(176.53 \mathrm{pg} / \mathrm{ml}, P<0.0001$, ANOVA) (Figure 3.13). For NK cells exposed to the MICA-129Val variant, the MICA expression intensity had a strong effect on IFN- $\gamma$ release $(1.103 \mathrm{pg} / \mathrm{ml}$ per MFI unit for MICA, $P<0.0001)$, in contrast to NK cells exposed to cells expressing the MICA-129Met variant $(0.142 \mathrm{pg} / \mathrm{ml}$ per MFI unit, $P=0.0001)$. IFN- $\gamma$ secretion of NK cells cultured in the absence of target cells or of NK cells exposed to L-con cells was not detectable or less than $25 \mathrm{pg} / \mathrm{ml}$ (data not shown).
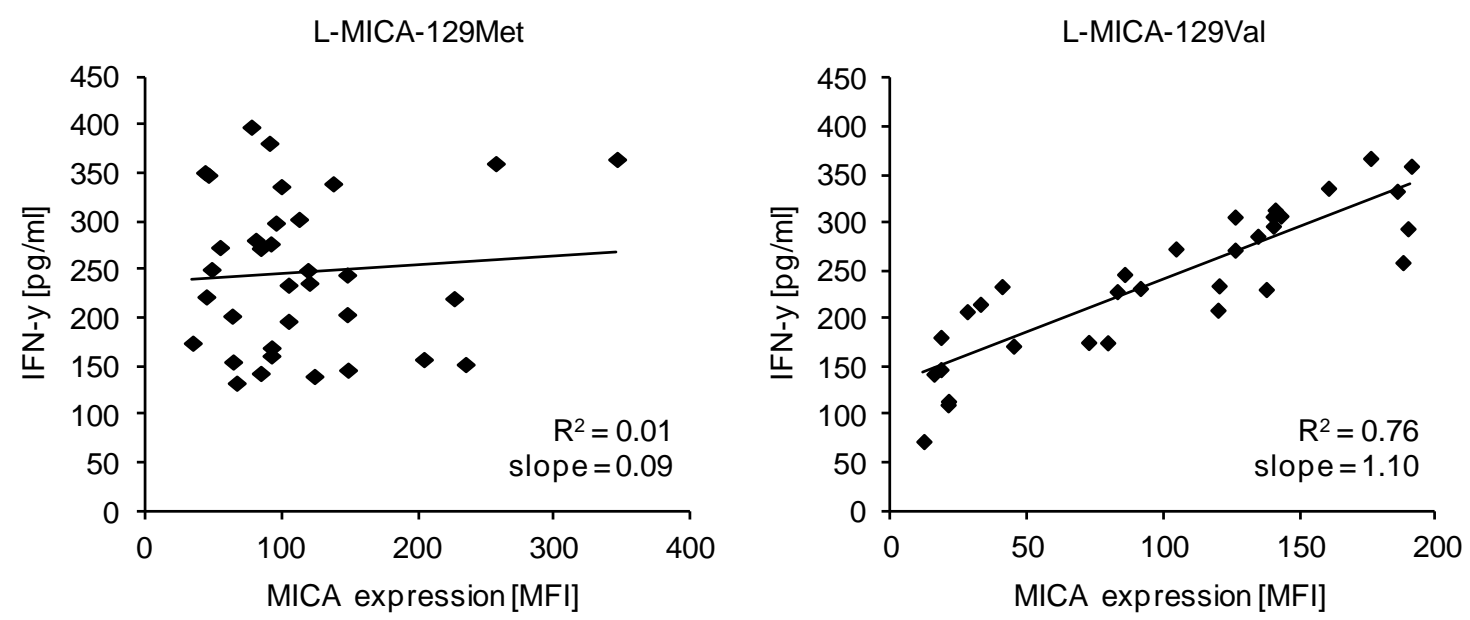

Figure 3.13: IFN- $-\gamma$ release of NK cells in response to the MICA-129Met and MICA-129Val variants is significantly different.

The IFN- $\gamma$ release of $2.5 \times 10^{5}$ purified IL-2-stimulated human NK cells ( $100 \mathrm{U} / \mathrm{ml}$ for 4 days) co-cultured with $5 \times$ $10^{4}$ L-MICA-129Met $(n=34)$ or L-MICA-129Val target cells $(n=32)$ for $24 \mathrm{~h}$ was measured in the supernatant by ELISA. In parallel, the MICA expression on target cells was determined by flow cytometry. The linear regression of IFN- $\gamma$ release $(\mathrm{pg} / \mathrm{ml})$ by NK cells and MICA expression on targets (MFI) is shown for L-MICA-129Met (left panel) and L-MICA-129Val cells (right panel). The slope of the regression line and the coefficient of determination $\left(R^{2}\right)$ are indicated for both MICA variants. 
In summary, the MICA-129Met variant is a stronger trigger not only of cytotoxic effects but also of IFN- $\gamma$ release by NK cells than the MICA-129Val variant. However, for the MICA-129Val variant again a significant main effect of the MICA expression intensity was apparent, in contrast to the Met variant.

\subsection{Impact of the MICA-129 dimorphism on MICA shedding and NKG2D counter-regulation}

Because of the different functional effects of the two MICA-129 variants on NK cell activity, including cytotoxicity and cytokine production, the question came up why an increasing expression of the high avidity MICA-129Met isoform did not trigger continuously stronger functional responses of NK cells as the low avidity MICA-129Val isoform did. It is known that ADAM proteases are able to cleave MICA from the cell surface (Groh et al., 2002; Salih et al., 2002; Kaiser et al., 2007; Waldhauer et al., 2008; Chitadze et al., 2013). This phenomenon, called MICA shedding, is thought to constitute a major counter-regulating mechanism of tumor cells to subvert NKG2D-mediated immunosurveillance (Waldhauer et al., 2008). Therefore, one possibility was that higher expression of MICA leads to higher concentration of soluble MICA (sMICA), which can inhibit NKG2D signaling by blocking or down-regulation of the receptor (Groh et al., 2002). This sMICA could block NKG2D signaling and blocking would presumably be more efficient for the MICA-129Met variant.

\subsubsection{Influence of the MICA-129 dimorphism on MICA shedding}

\subsubsection{MICA shedding of mouse L-MICA-129-expressing cells}

First, we analyzed whether the mouse L-MICA-129Met and Val transfectants, which we used for the previous functional experiments, show MICA shedding. The concentration of sMICA in the supernatant of L-MICA-129Met and L-MICA-129Val-expressing cells cultured for $24 \mathrm{~h}$ was determined using a sMICA ELISA. The MICA cell surface expression of these cells was measured in parallel by flow cytometry. It turned out that the MICA-129-transfected L cells did not release MICA into the supernatant in contrast to human melanoma cell lines which served as positive control and released detectable amounts of sMICA into the medium, especially after induction of the MICA expression with the histone deacetylase (HDAC) inhibitor SAHA (Table 3.1). The observed absence of MICA 
shedding in MICA-129Met/Val-expressing L cells is likely a feature of mouse $L$ cells, or perhaps of mouse cells in general which do not possess MICA/B, since both variants were shed when they were expressed in a human tumor cell lines (see 3.4.1.2).

Table 3.1: Analysis of MICA shedding from L-MICA-129Met and L-MICA-129Val cells.

\begin{tabular}{lccc} 
Cell type & $\mathbf{n}^{1}$ & $\begin{array}{c}\text { MICA [MFI] } \\
\text { mean } \pm \text { SEM }\end{array}$ & $\begin{array}{c}\text { sMICA [pg/10 } \\
\text { mean } \pm \text { SEM }\end{array}$ \\
\hline \hline Ltk $^{-}$ & 3 & $0.8 \pm 0.0$ & $0.0 \pm 0.0$ \\
\hline L-con & 3 & $0.5 \pm 0.2$ & $0.0 \pm 0.0$ \\
\hline L-MICA-129Met & 12 & $83.6 \pm 16.9$ & $0.0 \pm 0.0$ \\
\hline L-MICA-129Val & 12 & $136.1 \pm 17.1$ & $0.0 \pm 0.0$ \\
\hline Melanomas & 4 & $13.0 \pm 4.6$ & $14.2 \pm 8.3$ \\
\hline Melanomas $+S A H A^{2}$ & 4 & $48.4 \pm 18.4$ & $79.2 \pm 12.7$ \\
\hline
\end{tabular}

${ }^{1}$ For the control cells (Ltk and L-con) 3 replicates cultured at different time points were analyzed, for L-MICA129 Met and L-MICA-129Met 12 independent clones were used and for melanomas, which served as positive controls, 4 different melanoma cell lines (Juso, Mel Ho, Parl and Sk Mel-29) were tested.

${ }^{2}$ The melanoma cell lines were treated with $10 \mu \mathrm{M}$ of the histone deacetylase (HDAC) inhibitor suberoylanilide hydroxyamic acid (SAHA, Qbiogene-Alexis, Grünberg, Germany) for $20 \mathrm{~h}$ before analysis to increase MICA expression as described previously (Elsner et al., 2010).

\subsubsection{MICA shedding of human tumor cell lines}

To clarify whether the absence of the MICA shedding phenomenon in the L-MICA-129Met/Val cells is a feature of mouse L cells, the three human tumor cell lines Malme (melanoma), T47D (breast carcinoma) and EPLC-272 (non-small cell lung carcinoma) were stably transfected with the pCMV6AC-MICA-129Met/Val expression constructs which were also used for transfection of the mouse L cells. We chose these three human tumor cell lines because the parental cell lines exhibited hardly any MICA cell surface expression and also treatment with the HDAC inhibitor SAHA did not considerably increase MICA expression compared to other human melanoma cell lines such as HT144, Juso, Mel Ei, Mel Ho and Sk Mel-29 (Figure 3.14). 


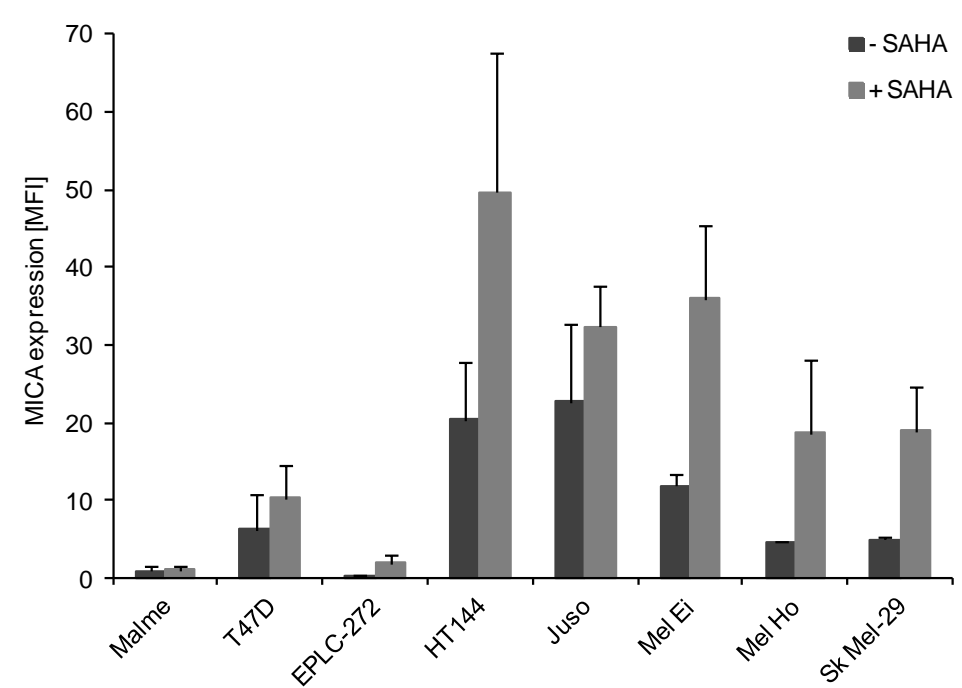

Figure 3.14: MICA cell surface expression of human tumor cell lines. Malme, HT144, Juso, Mel Ei, Mel Ho and Sk Mel-29 are melanoma cell lines, T47D is a breast carcinoma and EPLC-272 a lung carcinoma cell line. For induction of MICA expression cell lines were also treated with the HDAC inhibitor SAHA (10 $\mu \mathrm{M})$ for $20 \mathrm{~h}$ before analysis. The MICA membrane expression was determined by flow cytometry using an anti-MICA mAb. The means plus SD of the MFIs of the MICA cell surface expression are shown $(n \leq 2)$.

Malme, T47D and EPLC-272 cells were transfected with either the MICA-129Met or MICA-129Val expression construct. The non-clonal pools of stably transfected cells revealed an increased MICA cell surface expression and higher amounts of SMICA in the cell supernatant compared to the corresponding wild type cell lines (Figure $3.15 \mathrm{~A}$ ) as determined by flow cytometry and SMICA ELISA, respectively. These results indicate that the MICA-129Met/Val proteins are shed by different human tumor cells in contrast to MICA on mouse L tumor cells transfected with MICA-129Met/Val expression constructs.

Furthermore, we were interested whether the MICA-129 genotype affects the MICA shedding. In contrast to T47D and EPLC-272 cells, which normally grow only in cell aggregates and died when single cells were seeded, MICA-129Met/Val-transfected Malme cells could be used for clonal selection. We compared the amount of sMICA of several MICA-129Met and MICA-129Val-expressing Malme clones. The statistical analysis indicated that the MICA expression intensities on different clones of both MICA-129 variants were similar $(P=0.3749, \mathrm{t}$ test $)$ but the variants significantly differed in the amount of sMICA in the cell supernatant $(P=0.0280, \mathrm{t}$ test $)$ as depicted in Figure 3.15 B. In addition, both variants showed a dependency of the MICA shedding on the MICA expression intensity which was stronger for the high avidity MICA-129Met variant (Figure $3.15 \mathrm{C}$ ). This result suggests that the MICA-129Met/Val dimorphism influences MICA shedding likely by a conformational change affecting the accessibility for ADAM proteases. 

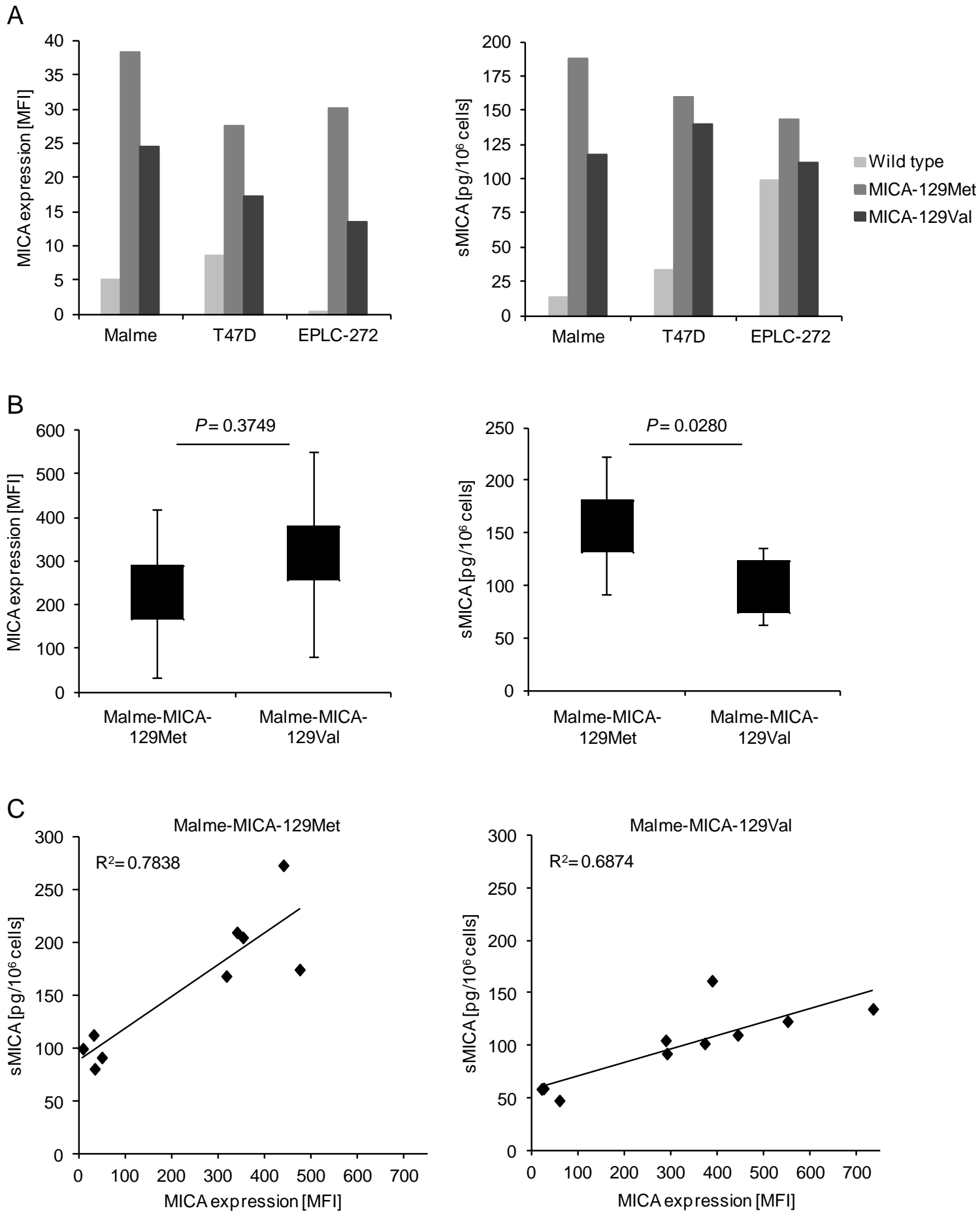

Figure 3.15: MICA shedding significantly differs between the MICA-129Met and MICA-129Val variants and is dependent on the MICA expression intensity.

(A) The MICA membrane expression intensity (left panel) and the amount of sMICA in the supernatant after 24 h (right panel) of the parental Malme, T47D and EPLC-272 cell lines (wild types) and of the pools of each of these three cell lines transfected with the MICA-129Met or MICA-129Val expression construct, respectively, before clonal selection are shown. In parallel to measurement of sMICA (pg/10 $0^{6}$ cells) by ELISA, MICA expression (MFI) was determined by flow cytometry. (B) The left panel illustrates the MICA expression intensity and the right panel the amount of sMICA in the supernatant of Malme-MICA-129Met $(n=9)$ and Malme-MICA$129 \mathrm{Val}$ cells $(n=10)$. The data were compared by an unpaired $t$ test and are shown in box-and-whisker plots. (C) The linear regression of MICA shedding and MICA membrane expression is shown for the Malme-MICA- 
129Met (left panel) and Malme-MICA-129Val cells (right panel). The regression line and the coefficient of determination $\left(R^{2}\right)$ are indicated in the figure for both MICA variants.

\subsubsection{NKG2D down-regulation on NK cells after co-culture with L-MICA-129 cells}

Besides soluble NKG2D ligands such as SMICA also sustained exposure of NK cells to NKG2D ligandexpressing cells can down-regulate the NKG2D receptor (Coudert et al., 2005; Oppenheim et al., 2005; Wiemann et al., 2005). For instance, it has been shown that the prolonged encounter with tumor cell-bound, but not soluble, ligand can completely uncouple NKG2D from the intracellular mobilization of calcium and the exertion of cell-mediated cytolysis (Coudert et al., 2005). Since the MICA-129-transfected mouse L cells did not show MICA shedding, we investigated whether the MICA-129 dimorphism has an impact on the NKG2D down-regulation of NK cells exposed to the LMICA-129 cells. Therefore, the NKG2D expression on IL-2-stimulated human NK cells exposed for $4 \mathrm{~h}$ and $24 \mathrm{~h}$ to L-con, L-MICA-129Met and L-MICA-129Val cells was analyzed by flow cytometry using an anti-NKG2D mAb (Figure 3.16 A). In parallel, CD94 expression was tested as a control which was expected not to be down- or up-regulated in response to MICA encounter (Figure 3.16 B). Analysis of the data revealed that NKG2D was indeed down-regulated on NK cells co-cultured with MICAexpressing cells compared to L-con cells (Figure 3.16 C). The percentage of NKG2D-positive NK cells $(-9.5 \%, P=0.0309$ for the Val variant and $-19.4 \%, P<0.0001$ for the Met variant, ANOVA) and the MFI of NKG2D $(-11.8 \%, P=0.0006$ for the Val variant and $-13.7 \%, P<0.0001$ for the Met variant, ANOVA) decreased. Notably, the percentage of NKG2D-positive cells decreased more among NK cells recognizing L-MICA-129Met than L-MICA-129Val targets (-9.3\%, $P=0.0008$, ANOVA). In addition, the MFI of NKG2D was significantly different between NK cells exposed to L-MICA-129Met and L-MICA$129 \mathrm{Val}$ targets ( $P=0.0225$, ANOVA; accounting for differences in the 24-hour time course). Moreover, the percentage of NKG2D-positive NK cells decreased with the time of co-culture $(P<$ 0.0001). NK cells co-cultured with MICA-negative or MICA-expressing $L$ cells did not show any differences in CD94 expression indicating the specificity of the effect (Figure 3.16 D). Hence, the MICA-129Met variant induces a stronger NKG2D counter-regulation on NK cells than the MICA$129 \mathrm{Val}$ variant. This counter-regulation appears to limit the initially stronger functional effects of the MICA-129Met variant on NKG2D signaling. 
A

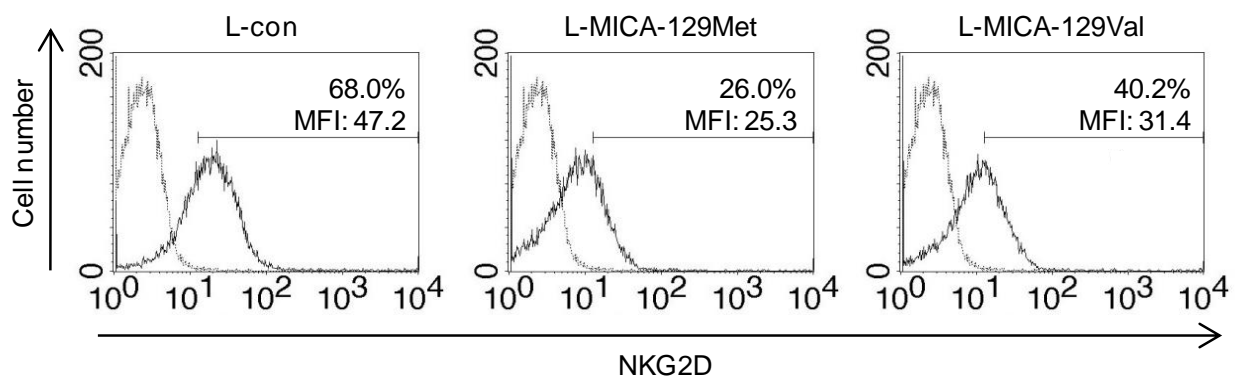

B

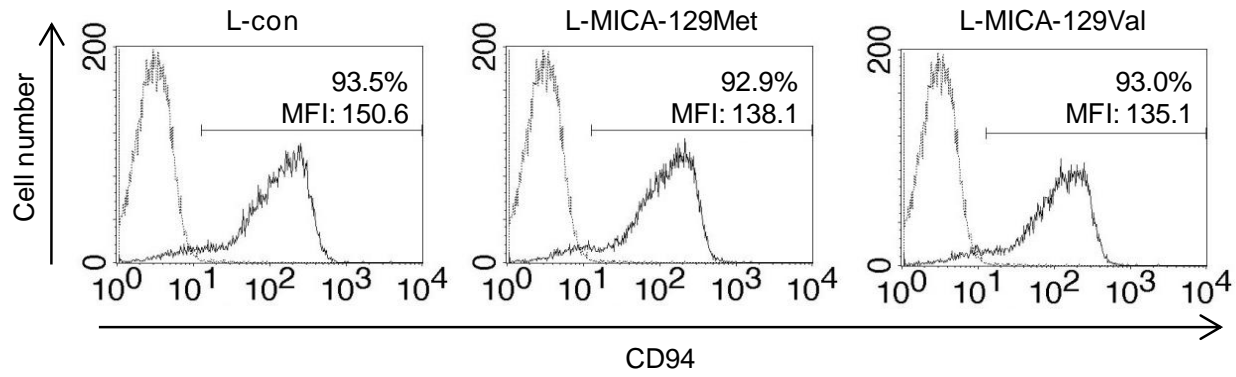

C
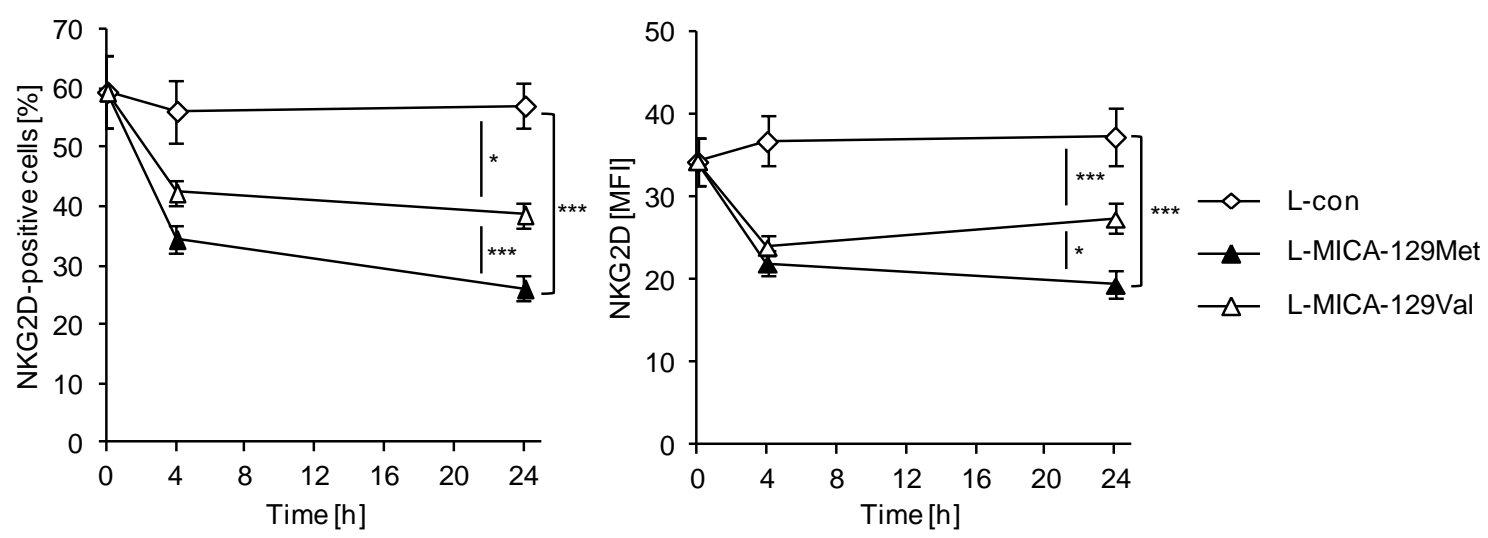

D
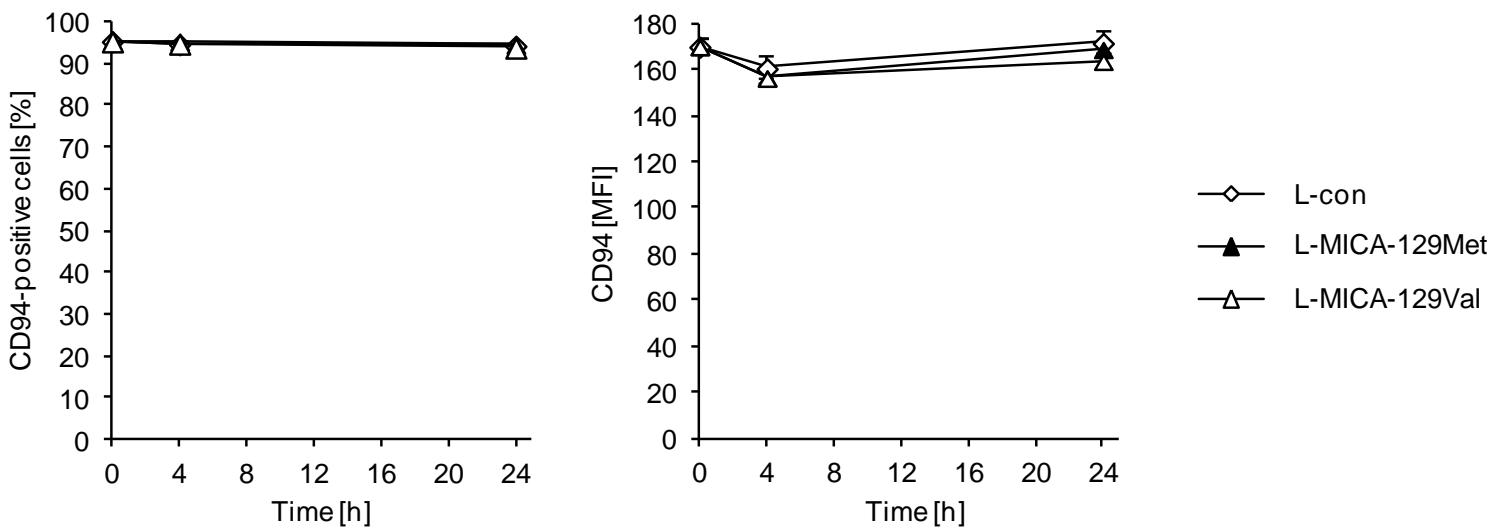

Figure 3.16: Less NKG2D down-regulation on NK cells co-cultured with L-MICA-129Val cells compared to LMICA-129Met cells.

(A) NKG2D expression on purified IL-2-stimulated human NK cells (100 U/ml for 4 days) co-cultured with L-con, L-MICA-129Met or L-MICA-129Val target cells for $24 \mathrm{~h}$ was analyzed by flow cytometry. NK cells $\left(2.5 \times 10^{5}\right)$ 
were co-cultured with target cells $\left(5 \times 10^{4}\right)$ in $200 \mu$ medium, stained with $10 \mu$ anti-NKG2D mAb and analyzed after gating on $\mathrm{CD}^{-} \mathrm{CD}_{56}{ }^{+}$cells. Black-lined histograms represent the NKG2D staining, while gray-lined histograms show the isotype control. The percentages of NKG2D+ cells and the MFI of NKG2D of these measurements are indicated in the histograms. (B) In parallel, the CD94 expression on the NK cells was determined. Black-lined histograms represent CD94 staining, while gray lines show the isotype control. The percentages of $\mathrm{CD}^{+}$cells and the MFI of CD94 of these measurements are indicated in the histograms. (C) NKG2D expression on NK cells exposed to L-MICA-129Met $(n=25)$ and L-MICA-129Val target cells $(n=25)$ for 0 , 4 and $24 \mathrm{~h}$. The means and SD means of the percentage of NKG2D ${ }^{+}$NK cells (left panel) and of the MFI of NKG2D (right panel) are shown. Differences between the groups were analyzed by ANOVA. (D) CD94 expression was determined in parallel. The means and SD means of the percentage of $\mathrm{CD}^{+} 4^{+} \mathrm{NK}$ cells (left panel) and of the MFI of CD94 (right panel) are shown. Differences between the groups were analyzed by ANOVA. The significance levels are given in the figure $(* P<0.05, * * P<0.01$ and $* * * P<0.001)$.

\subsection{Establishment of a mouse model for studying the impact of the MICA- 129 dimorphism on an experimental adoptive immunotherapy of cancer}

Our data, showing that the MICA-129Met/Val polymorphism is functionally relevant, encouraged us to investigate whether the SNP may also affect the therapeutic efficacy of an experimental adoptive immunotherapy of MICA-expressing tumors with activated human NK cells using immunodeficient mice. In parallel, we tried to optimize the in vitro stimulation of human NK cells for targeting MICAexpressing tumors in vivo as well as the NK cell transfer protocol.

\subsubsection{Tumor growth after inoculation of L-MICA-129 cells}

Initially, $10^{6}$ or $5 \times 10^{6}$ mouse $L$ tumor cells were subcutaneously (s.c.) injected into the flank of C.B17/Ztm-scid mice, which lack B and T lymphocytes but still possess functional NK cells, to examine whether tumor growth is caused. The experiment indicated that injection of $L$ cells leads to tumor growth within approximately 2 or 4 weeks for both injected tumor cell doses (Table 3.2). At the time point of autopsy, the tumor frequency was $100 \%$. Dissection of the animals revealed a non-invasive growth of primary tumors without development of macrometastases. 
Table 3.2: Tumor growth of different $L$ cell lines in immunodeficient mice.

\begin{tabular}{|c|c|c|c|c|c|}
\hline Mouse strain $^{1}$ & $\begin{array}{l}\text { Number and cell type of } \\
\text { injected cells per animal }^{2}\end{array}$ & $\begin{array}{c}\text { Number } \\
\text { of } \\
\text { animals }\end{array}$ & $\begin{array}{c}\text { Tumor } \\
\text { frequency } \\
(\text { day } x)^{3}\end{array}$ & $\begin{array}{c}\text { Day of autopsy } \\
\text { mean } \pm \text { SD }\end{array}$ & $\begin{array}{c}\text { Tumor size } \\
\left(\mathrm{cm}^{3}\right) \\
\text { mean } \pm S D^{4}\end{array}$ \\
\hline C.B-17/Ztm-scid & $10^{6} \mathrm{Ltk}^{-}$ & 3 & $0 \%$ (day 10$)$ & $28.0 \pm 0.0$ & $3.35 \pm 1.72$ \\
\hline C.B-17/Ztm-scid & $5 \times 10^{6} \mathrm{Ltk}^{-}$ & 5 & $80 \%$ (day 10$)$ & $14.0 \pm 0.0$ & $1.86 \pm 1.03$ \\
\hline C57BL/6-Rag2 $2^{-/-} / \mathrm{cyc}^{-/-}$ & $10^{6}$ L-con & 3 & $67 \%$ (day 28 ) & $30.0 \pm 0.0$ & $0.98 \pm 0.27$ \\
\hline C57BL/6-Rag2 $2^{-/-} / \mathrm{cyc}^{-/-}$ & $10^{6}$ L-MICA-129Met & 3 & $67 \%$ (day 28 ) & $33.0 \pm 5.2$ & $0.99 \pm 0.56$ \\
\hline C57BL/6-Rag2 $2^{-/-} / \mathrm{cyc}^{-/-}$ & $10^{6}$ L-MICA-129Val & 3 & $100 \%$ (day 28 ) & $18.0 \pm 0.0$ & $1.60 \pm 0.26$ \\
\hline
\end{tabular}

${ }^{1}$ C.B-17/Ztm-scid mice do not possess $\mathrm{B}$ and $\mathrm{T}$ lymphocytes, while $\mathrm{C} 57 \mathrm{BL} / 6-\mathrm{Rag} 2^{-/-} / \mathrm{cpc}^{-/-}$are deficient in $\mathrm{B}, \mathrm{T}$ and NK cells.

${ }^{2} 10^{6}$ or $5 \times 10^{6}$ cells in $100 \mu$ l sterile PBS were subcutaneously (s.c.) inoculated into the left flank of the animals.

${ }^{3}$ Percentage of animals in which primary tumors were palpable at different time points.

${ }^{4}$ After scarification tumors were prepared and tumor size was measured using a linear caliper. Tumor volume was calculated by the formula $V=\pi a b c / 2$, where $a, b, c$ are the orthogonal diameters.

In a second experiment, $10^{6}$ MICA-129Met and Val-expressing $L$ cells as well as MICA-negative L-con cells were s.c. inoculated into the flank of $\mathrm{C} 57 \mathrm{BL} / 6-\mathrm{Rag}^{-1-} / \mathrm{c}^{-1-}$ immunodeficient mice lacking besides $B$ and $T$ cells also NK cells. Tumor formation was observed in all animals at autopsy and dissections also revealed non-invasive tumor growth without development of metastases (Table 3.2). Injection of $10^{6} \mathrm{~L}$-con cells showed similar tumor formation as inoculation of the same amount of parental $L$ cells in SCID mice. The three mice injected with MICA-129Val-expressing cells had to be scarificed early at day 18. However, this must not indicate an effect of the MICA-129Val variant but could also be due to clonal variation. This finding indicated the necessity to use several clones of each MICA-129 variant with similar MICA cell surface expression and similar proliferation rates for in vivo experiments. Immunohistochemistry of tumor sections using an anti-MICA mAb exemplified that inoculation of L-MICA-129 tumor cells (L-MICA-129Met clone 1 and L-MICA-129Val clone 1) resulted in growth of MICA-expressing tumors in contrast to injection of L-con cells (Figure 3.17).

Next, we analyzed the proliferation of several clones of each MICA-129 variant and L control cells by ${ }^{3} \mathrm{H}$-thymidine incorporation assays. However, we did not find a major difference in the in vitro proliferation rate between cell clones expressing the MICA-129Met or MICA-129Val variant in vitro (see Appendix, Figure A.2). 

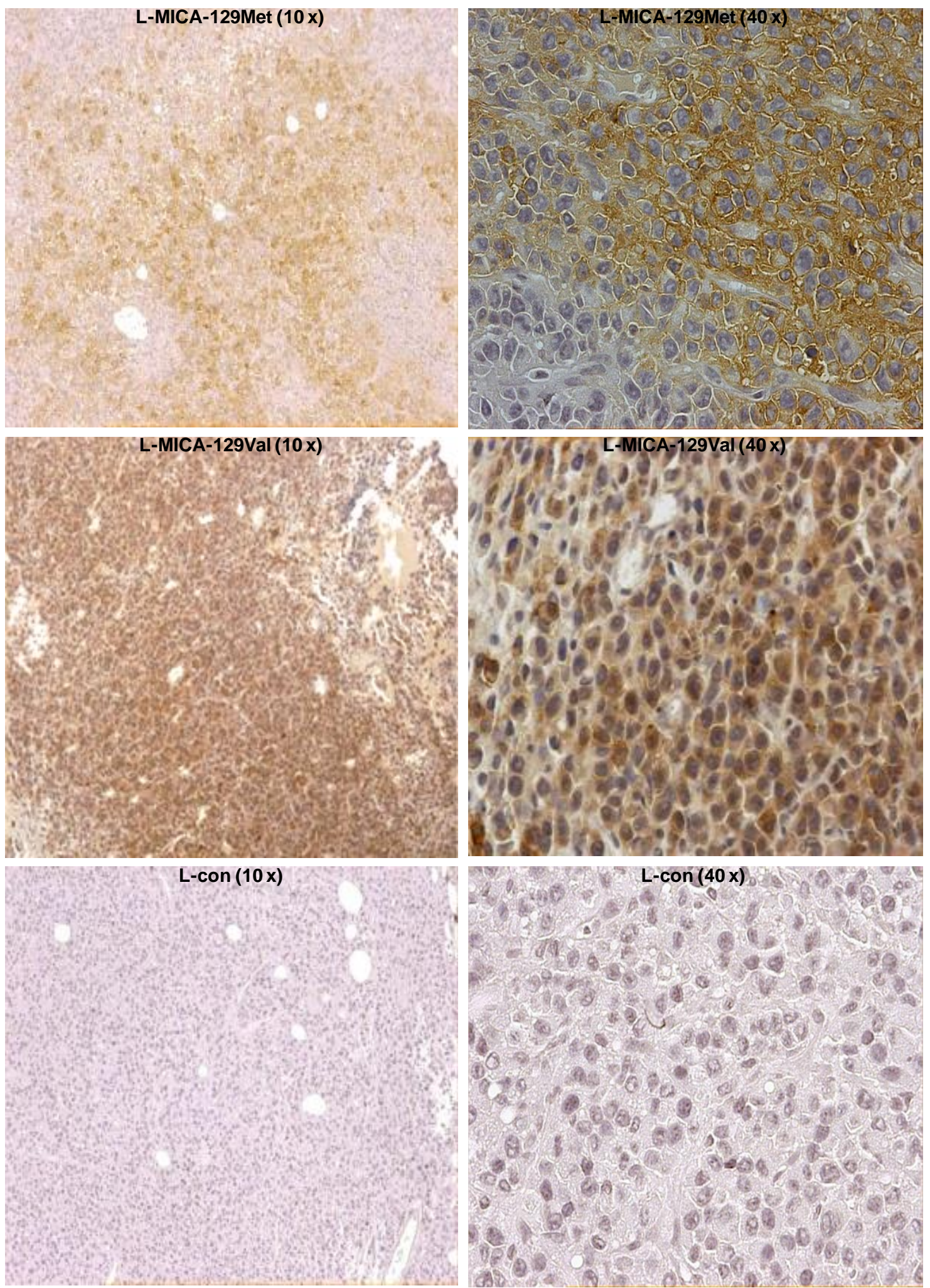

Figure 3.17: Immunohistochemistry of non-invasive tumors after injection of L-MICA-129 and L-con cells.

For immunohistochemistry, paraffin sections were incubated with an anti-MICA mAb followed by an additional staining of the cell nuclei with hemalum (blue). DAB staining (brown) indicates MICA membrane expression in a non-invasive primary tumor after s.c. injection of $10^{6}$ L-MICA-129Met cells (upper panel) or L-MICA-129Val cells (middle panel) into the flank of a C57BL/6-Rag2 $2^{-1 /} / \mathrm{crc}^{-/-}$immunodeficient mouse. As control $10^{6} \mathrm{~L}$-con cells were inoculated resulting in growth of a primary MICA-negative tumor (lower panel). 


\subsubsection{Adoptive NK cell therapy of L-MICA-129-bearing mice}

In a pilot experiment, we treated immunodeficient mice with L-MICA-129Met/Val-expressing tumors by adoptive transfer of human NK cells. In total, 36 C57BL/6-Rag $2^{-/} / \mathrm{cpc}^{-/-}$mice divided in six different groups, each comprising of six mice, were treated (Table 3.3). First, $10^{6}$ L-con cells, MICA129Met/Val-expressing L cells (L-MICA-129Met clone 2 and L-MICA-129Val clone 2) were s.C. inoculated into the flank of 12 animals. At day 4 after tumor cell inoculation, 6 animals in each group were treated with $3 \times 10^{6}$ human NK cells, stimulated for 4 days with $100 \mathrm{U} / \mathrm{ml}$ IL-2, and the other 6 mice received as control only $100 \mu$ PBS injected intravenously (i.v.) into the tail vein. The mice were sacrificed between day 18 and 39 depending on the tumor growth (Table 3.3). They showed noninvasive growth of primary tumors without the development of metastases. No difference in the lifespan or in the tumor size was observed between mice treated with NK cells or the PBS control (Table 3.3). At the time of autopsy, the transferred NK cells were not detectable anymore by flow cytometry in blood, spleen or tumor (data not shown) indicating a limited lifespan of the human NK cells in the recipient mice.

Table 3.3: Tumor growth of different $L$ cell lines in immunodeficient C57BL/6-Rag2 $2^{-/ / \mathrm{cpc}^{-/-}}$mice. $^{-}$

\begin{tabular}{|c|c|c|c|c|c|}
\hline $\begin{array}{l}\text { Number and cell type of } \\
\text { injected cells per animal }\end{array}$ & Treatment $^{2}$ & $\begin{array}{l}\text { Number of } \\
\text { animals }\end{array}$ & $\begin{array}{c}\text { Tumor } \\
\text { frequency } \\
\text { (day 28) }^{3}\end{array}$ & $\begin{array}{c}\text { Day of } \\
\text { autopsy } \\
\text { mean } \pm \text { SD }\end{array}$ & $\begin{array}{l}\text { Tumor size } \\
\left(\mathrm{cm}^{3}\right) \\
\text { mean } \pm \mathrm{SD}^{4}\end{array}$ \\
\hline $10^{6} \mathrm{~L}-\mathrm{con}$ & $3 \times 10^{6} \mathrm{NK}$ cells & 6 & $83 \%$ & $25.3 \pm 4.8$ & $1.93 \pm 0.75$ \\
\hline $10^{6} \mathrm{~L}-\mathrm{con}$ & PBS & 6 & $100 \%$ & $24.0 \pm 3.6$ & $1.89 \pm 0.84$ \\
\hline $10^{6}$ L-MICA-129Met & $3 \times 10^{6} \mathrm{NK}$ cells & 6 & $100 \%$ & $21.7 \pm 2.1$ & $1.86 \pm 0.59$ \\
\hline $10^{6}$ L-MICA-129Met & PBS & 6 & $83 \%$ & $23.7 \pm 4.6$ & $1.13 \pm 0.37$ \\
\hline $10^{6}$ L-MICA-129Val & $3 \times 10^{6} \mathrm{NK}$ cells & 6 & $67 \%$ & $32.7 \pm 4.4$ & $1.22 \pm 0.53$ \\
\hline $10^{6}$ L-MICA-129Val & PBS & 6 & $50 \%$ & $34.3 \pm 5.3$ & $1.20 \pm 0.69$ \\
\hline
\end{tabular}

${ }^{1} 10^{6}$ cells in $100 \mu$ l sterile PBS were subcutaneously (s.c.) inoculated into the left flank of the animals.

${ }^{2} 3 \times 10^{6}$ human NK cells, stimulated for $4 \mathrm{~d}$ with $100 \mathrm{U} / \mathrm{ml} \mathrm{IL-2,} \mathrm{in} 100 \mu \mathrm{l}$ sterile PBS or as control $100 \mu \mathrm{l}$ PBS only were intravenously (i.v.) injected into the tail vein at day 4 after tumor cell inoculation.

${ }^{3}$ Percentage of animals in which primary tumors were palpable at day 28.

${ }^{4}$ After scarification tumors were prepared and tumor size was measured using a linear caliper. Tumor volume was calculated by the formula $V=\pi a b c / 2$, where $a, b, c$ are the orthogonal diameters. 


\subsubsection{Optimization of NK cell stimulation for adoptive transfer}

It has been reported that in addition to IL-2 stimulation pre-activation of NK cells with the three cytokines IL-12, IL-15 and IL-18 improved antitumor NK cell activity (Ni et al., 2012). Therefore, we added IL-12, IL-15 and IL-18 to MACS-isolated human NK cells for the last $16 \mathrm{~h}$ of an overall 4 day stimulation with IL-2. The expression of the two NK cell markers CD16 and CD56, the activation marker CD69, the NK cell receptors CD94, NKG2D, DNAM-1, and 2B4 as well as the three natural cytotoxicity receptors (NCRs) NKp30, NKp44 and NKp46 was determined by flow cytometry. The NK cells of four different donors at three different time points - directly after MACS isolation, after $4 \mathrm{~d}$ IL-2 stimulation (100 U/ml) only and after IL-2 stimulation plus additional activation with IL-12, IL-15 and IL-18 - were analyzed. The expression of the activation marker CD69 increased after stimulation with the additional cytokines in comparison to NK cells stimulated only with IL-2 (Figure $3.18 \mathrm{~A}$ ). The expression of the NK cell receptors and NCRs was similar but CD16 expression decreased. The amount of CD56 dim compared to CD56 $6^{\text {bright }}$ NK cells increased after additional stimulation suggesting an increase of NK cells with cytotoxic activity. In parallel, we also investigated whether the additional cytokine activation indeed resulted in changes of the cytotoxic activity of NK cells towards MICA-129expressing target cells using the CD107a expression assay. However, the NK cells showed no major difference regarding degranulation when attacking MICA-129Met or MICA-129Val-expressing L target cells after the two different pre-stimulation protocols (Figure $3.18 \mathrm{~B}$ ).

Moreover, we co-cultured isolated human NK cells together with irradiated allogeneic PBMCs, socalled 'feeder cells', and $250 \mathrm{U} / \mathrm{ml} \mathrm{IL-2} \mathrm{for} 2$ weeks to expand and pre-activate the NK cells. The initial number of NK cells increased 3-fold within 7 days, however, prolonged co-culture did not lead to a further increase of NK cells in our hands. The MFI of CD56 expression strongly increased during culture, while the percentage of CD56-positive cells remained similar from day 0 to day 14 indicating that the portion of CD56 ${ }^{\text {bright }}$ NK cells increased (see Appendix, Figure A.3). In addition, the MFI of CD16 expression decreased, whereas the percentage of CD94-positive cells as well as the MFI of CD94 increased. Thus, the expansion of NK cells was associated with a decrease of the portion of CD56 ${ }^{\mathrm{dim}} \mathrm{NK}$ cells which are known to exert the cytotoxic activity.

In summary, the preliminary in vivo experiments for the treatment of MICA-expressing tumors with an adoptive transfer of activated human NK cells revealed the necessity to further optimize the in vitro stimulation of NK cells as well as the NK cell transfer protocol to obtain long NK cell survival and vigorous NK cell activity. 
A

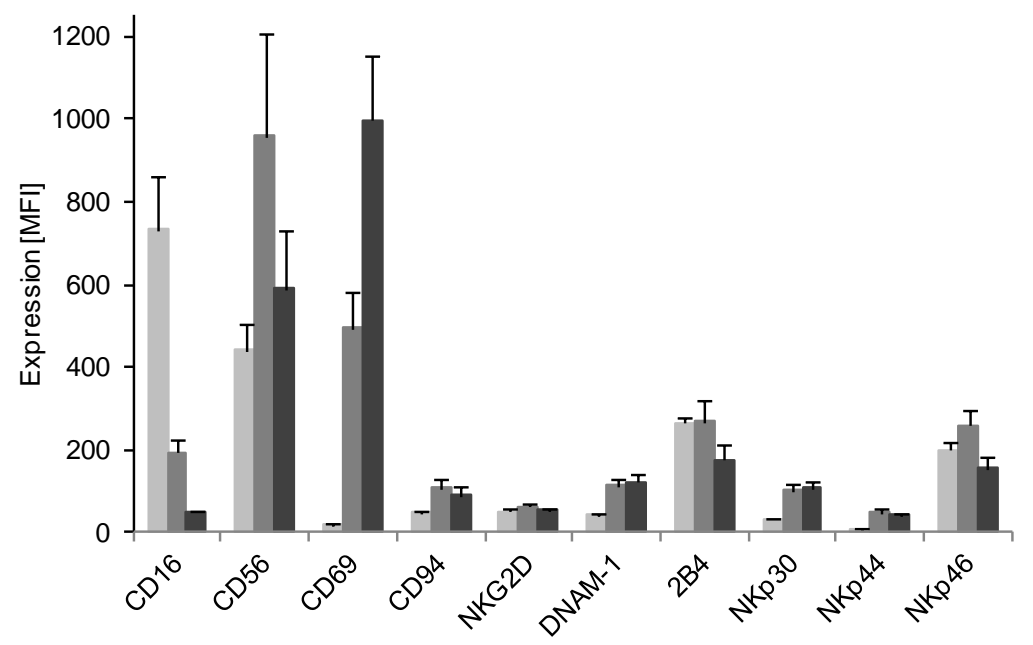

No stimulation (d0)

- IL-2 (d4)

- IL-2 + IL-12/15/18 (d4)

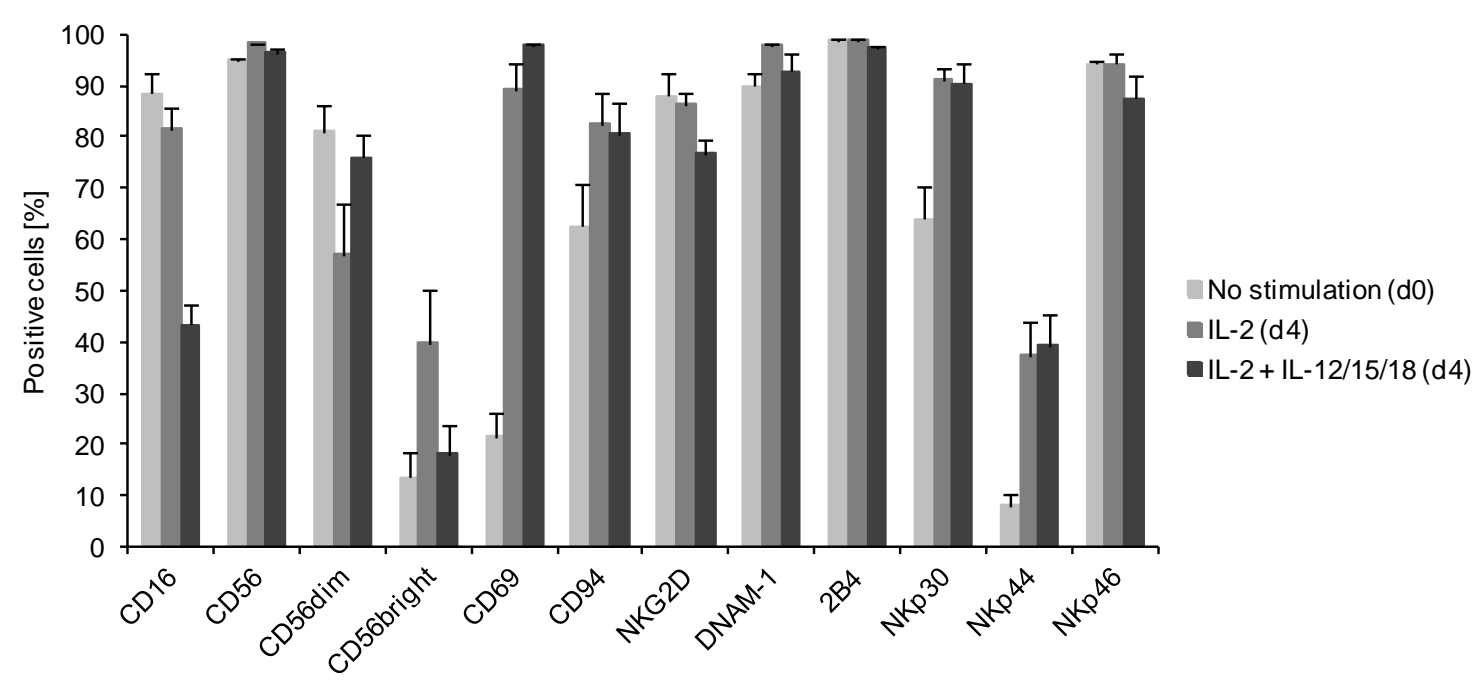

B
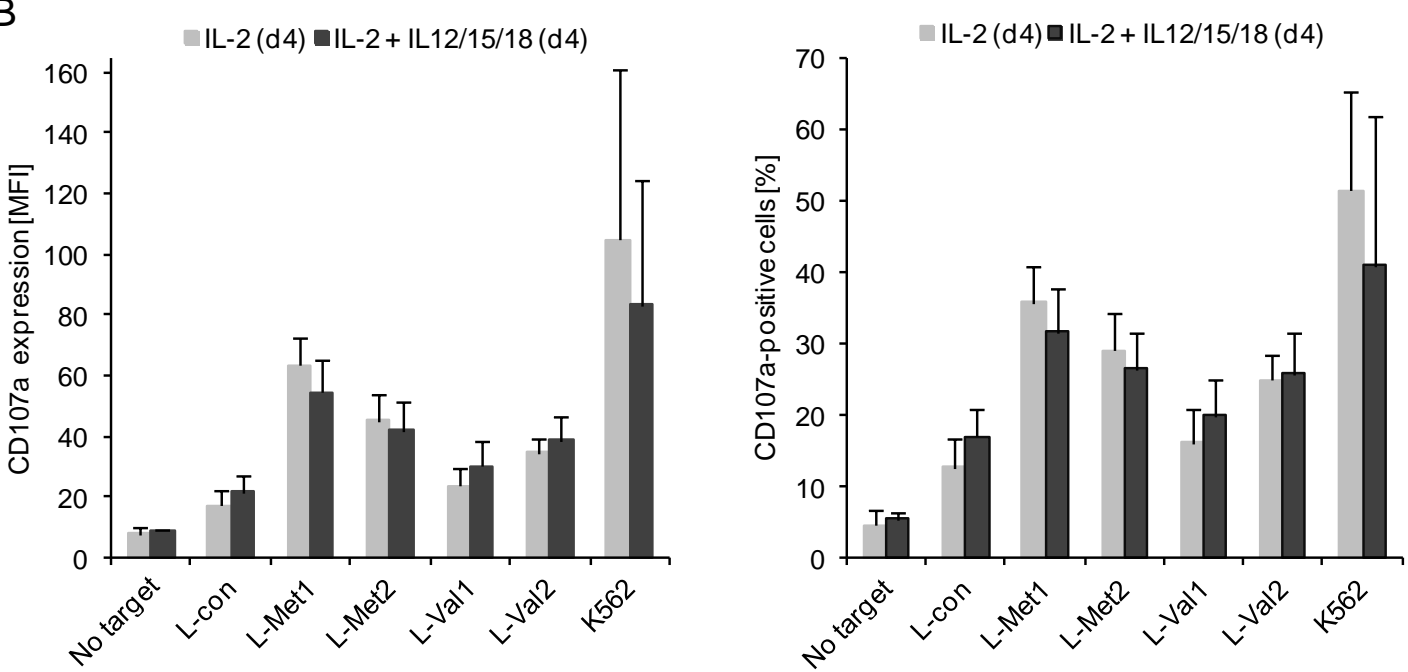

Figure 3.18: Expression of NK cell receptors and degranulation of NK cells after IL-12/15/18 pre-activation.

(A) The expression of the two NK cell markers CD16 and CD56, the activation marker CD69 and different NK cell receptors such as CD94, NKG2D, DNAM-1, 2B4 and the three natural cytotoxicity receptors (NCRs) NKp30, 
Nkp44 and Nkp46 was determined by flow cytometry using mAbs against these receptors. Human NK cells of different donors $(n=4)$ directly after MACS isolation, after $4 \mathrm{~d}$ IL-2 stimulation $(100 \mathrm{U} / \mathrm{ml})$ only and after IL-2 stimulation plus additional pre-activation with IL-12 (10 ng/ml), IL-15 (10 ng/ml) and IL-18 (50 ng/ml) was analyzed. The three additional cytokines were added for the last $16 \mathrm{~h}$ of the 4-day IL-2 stimulation. The upper panel shows the means of the NK cell receptor expression as MFIs plus SEM and the lower panel shows the percentage of positive cells plus SEM. (B) NK cells, stimulated with IL-2 only or with IL-2 plus IL-12/15/18, were exposed to no target cells, L-con, two clones of L-MICA-129Met and L-MICA-129Val cells and K562 cells. CD107a expression was determined by flow cytometry using an anti-CD107a mAb and is given as mean $(n=3)$ and SEM of MFIs (left panel) or percentage of $\mathrm{CD}_{107^{+}}$cells plus SEM (right panel).

\subsection{Association of the MICA-129 dimorphism with survival and GVHD after HSCT}

To investigate further whether the MICA-129 dimorphism is clinically relevant, 320 patient and donor (P/D) pairs undergoing allogeneic HSCT in the Department of Hematology and Medical Oncology at the University Medical Center Göttingen were typed for the SNP rs1051792 (A/G), which is responsible for the MICA-129Met/Val polymorphism. For typing an allele-specific TaqMan MICA-129 genotyping assay was used. An example for an allelic discrimination plot of several control DNAs from heterozygous and homozygous tumor cell lines is shown in Figure 3.19.

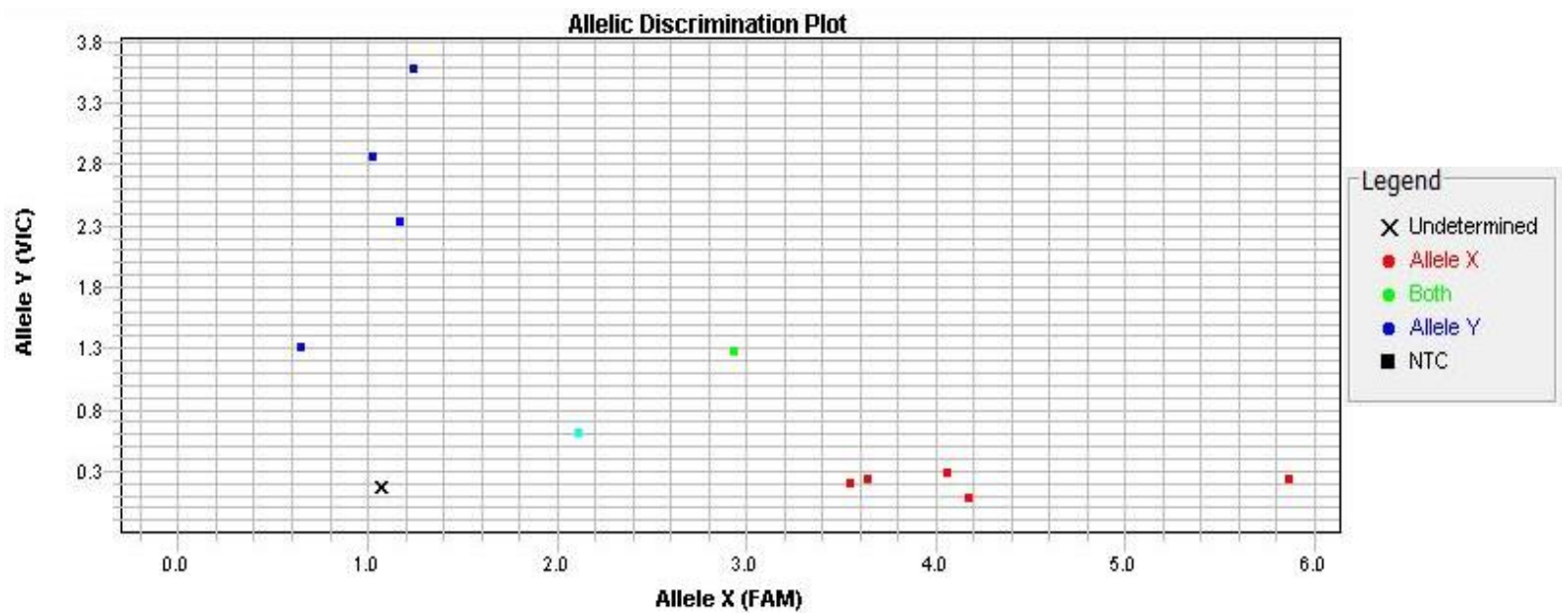

Figure 3.19: Genotyping for the MICA-129 dimorphism by an allele-specific TaqMan assay.

Genomic DNA (10 ng) from heterozygous and homozygous human tumor cell lines and mouse L-MICA129Met/Val transfectants $(n=12)$ were genotyped for the MICA-129 dimorphism using an allele-specific TaqMan genotyping assay. These cell lines, which were already typed before for the SNP 454 (rs1051792, A (Met) or G (Val)) by PCR using sequence-specific oligonucleotides, served as controls for the genotyping of genomic DNAs of the 320 patients and donors from the Göttingen HSCT cohort. The allelic discrimination plot indicates which cell lines are homozygous for MICA-129Val (Allele X detected via a FAM-labeled MGB probe), homozygous for MICA-129Met (Allele Y detected via a VIC-labeled MGB probe) or heterozygous for the MICA129 polymorphism. 
The analysis of the data obtained from the MICA-129 genotyping of the 320 P/D pairs revealed that the Met $(\mathrm{A})$ or Val $(\mathrm{G})$ alleles occurred with a frequency of $31.5 \%$ or $68.5 \%$ in patients and $32.4 \%$ or $67.6 \%$ in donors, respectively (Table 3.4). The majorities of patients and donors were homozygous for $\operatorname{Val}(\mathrm{G} / \mathrm{G})(48.1 \%$ or $47.2 \%)$, more than one third were heterozygous $(\mathrm{A} / \mathrm{G})(36.9 \%$ or $36.6 \%)$ and the minority was homozygous for Met (A/A) (12.2\% or $13.1 \%)$, which approximately reflects the reported genotype frequencies for this polymorphism in the Caucasian population (Zou and Stastny, 2011). Most of the P/D pairs $(274,85.6 \%)$ had the same MICA-129 genotype. 175 of the patients undergoing HSCT experienced aGVHD (54.7\%, any grade), 104 cGVHD (32.5\%, any grade) and in 69 (21.6\%) a relapse of disease occurred. The overall survival rate was $48.1 \%$ and the treatment-related mortality $22.8 \%$.

Table 3.4: HSCT pairs, diseases, transplantation characteristics and outcome.

\begin{tabular}{|c|c|}
\hline Characteristics & Values \\
\hline \multicolumn{2}{|l|}{ Recipients $(n=320)$} \\
\hline Median age, $y$ & 51 \\
\hline Younger than $20 \mathrm{y}, \mathrm{n}(\%)$ & $6(1.9)$ \\
\hline 20 to $40 \mathrm{y}, \mathrm{n}(\%)$ & $53(16.9)$ \\
\hline Older than 40 y, n (\%) & $261(81.6)$ \\
\hline Male, $\mathrm{n}(\%)$ & $191(59.7)$ \\
\hline \multicolumn{2}{|l|}{ MICA-129 polymorphism } \\
\hline \multicolumn{2}{|l|}{ Genotype frequencies } \\
\hline Met/Met, n (\%) & $39(12.2)$ \\
\hline Met/Val, n (\%) & $118(36.9)$ \\
\hline Val/Val, n (\%) & $154(48.1)$ \\
\hline ND, n (\%) & $9(2.8)$ \\
\hline \multicolumn{2}{|l|}{ Allele frequencies } \\
\hline Met, n (\%) & $196(31.5)$ \\
\hline Val, n (\%) & $426(68.5)$ \\
\hline \multicolumn{2}{|l|}{ Underlying diagnosis } \\
\hline Hodgkin lymphoma, non-Hodgkin lymphoma, n (\%) & $133(41.6)$ \\
\hline Acute leukemia, n (\%) & $118(36.9)$ \\
\hline Multiple myeloma, n (\%) & $32(10.0)$ \\
\hline Myelodysplastic syndrome, n (\%) & $18(5.6)$ \\
\hline Myeloproliferative diseases, chronic myeloid leukemia, $n$ (\%) & $12(3.8)$ \\
\hline Other diagnoses, $\mathrm{n}(\%)$ & $7(2.2)$ \\
\hline \multicolumn{2}{|l|}{ Disease status for malignant disorders } \\
\hline Early, n (\%) & $97(30.3)$ \\
\hline Intermediate, $\mathrm{n}(\%)$ & 99 (30.9) \\
\hline Advanced, $\mathrm{n}(\%)$ & $124(38.8)$ \\
\hline
\end{tabular}

Donors $(n=320)$ 
Median age, $y$

Younger than $20 \mathrm{y}, \mathrm{n}(\%)$

20 to $40 \mathrm{y}, \mathrm{n}(\%)$

Older than $40 \mathrm{y}, \mathrm{n}(\%)$

ND, $\mathrm{n}(\%)$

Male, n (\%)

Female donor to male recipient, $\mathrm{n}(\%)$

HLA-matched unrelated donor, $\mathrm{n}(\%)$

HLA-mismatched donor, $\mathrm{n}$ (\%)

Related donor, $\mathrm{n}$ (\%)

MICA-129 polymorphism

Genotype frequencies

Met/Met, n (\%)

Met/Val, n (\%)

Val/Val, n (\%)

ND, $\mathrm{n}(\%)$

Allele frequencies

Met, n (\%)

Val, n (\%)

\section{Transplantation}

Source of stem cells

Peripheral blood, n (\%)

Bone marrow, n (\%)

Conditioning

Busulfan-based, n (\%)

Total-body irradiation-based, $\mathrm{n}(\%)$

Reduced intensity conditions, $\mathrm{n}(\%)$

$\mathrm{T}$ cell depletion, $\mathrm{n}$ (\%)

\section{Outcome}

Occurrence of acute GVHD, $\mathrm{n}(\%)$

Grade I to II, n (\%)

Grade III to IV, n (\%)

42 (13.1)

117 (36.6)

151 (47.2)

10 (3.1)

$201(32.4)$

$419(67.6)$

311 (97.2)

9 (2.8)

284 (88.8)

36 (11.3)

67 (20.9)

149 (46.6)

175 (54.7)

108 (33.8)

67 (20.9)

104 (32.5)

69 (21.6)

166 (51.9)

73 (22.8)

54 (16.9)

ND indicates not determined or missing data.

The association of the MICA-129 dimorphism with the outcome of HSCT for P/D pairs matched on the MICA-129 genotype was analyzed after adjustment for relevant clinical covariates. Carriers of the Val variant had an increased risk of death after HSCT. In heterozygous carriers the hazard ratio (HR) was 
1.31 (95\%-confidence interval ( $\mathrm{Cl}$ ) 1.013-1.689; $P=0.0395$, additive risk model) and homozygous carriers had a two times higher risk estimate on the logarithmic scale. A similar trend was observed in the whole cohort ( $\mathrm{HR}=1.23$ for heterozygous patients; $95 \%-\mathrm{Cl} 0.968-1.571 ; P=0.0897$ ). Particularly, homozygous carriers of the Val variant had a lower probability of survival compared to homozygous carriers of the Met variant (Figure 3.20 A-B). The Met/Met genotype was associated with an increased risk of aGVHD (odds ratio $(\mathrm{OR})=2.27 ; 95 \%-\mathrm{Cl} 1.09-5.09 ; P=0.0361$, recessive risk model) in the whole cohort but presence of Met alleles was also associated with a lower risk of death due to aGVHD (OR $=0.42 ; 95 \%-\mathrm{Cl}, 0.25-0.90 ; P=0.0012)$. Inversely, the $\mathrm{Val} /$ Val genotype was associated with an increased risk of death due to aGVHD (OR $=2.40 ; 95 \%-\mathrm{Cl}, 1.11-4.04 ; P=0.0012)$. These outcomes were statistically significant also for P/D pairs matched on the MICA-129 genotype. The Met variant appeared to be associated with a higher risk of cGVHD without reaching the 5\%significance-level in the whole cohort (OR $=1.40$ for heterozygous and 1.96 for homozygous patients; 95\%-Cl, 0.961-2.042; $P=0.0795$, additive risk model). The MICA-129 SNP was not significantly associated with the risk of relapse.

In summary, the MICA-129Met variant appeared to confer a higher risk of aGVHD but overall beneficial effects on survival after HSCT. Since we have shown that the MICA-129 dimorphism is functionally relevant, it is conceivable that this polymorphism is not only associated with but is directly causative for the observed differences in the outcome of HSCT.

A

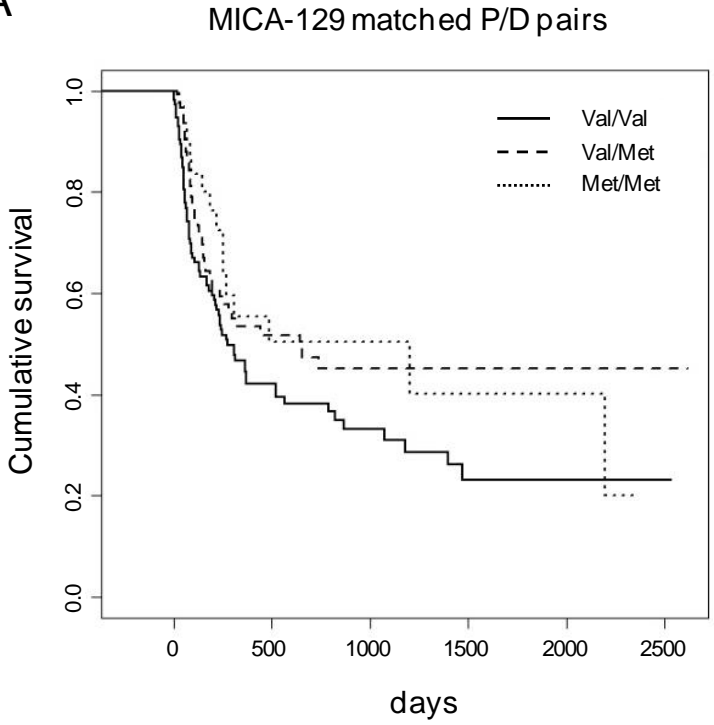

B

Whole cohort

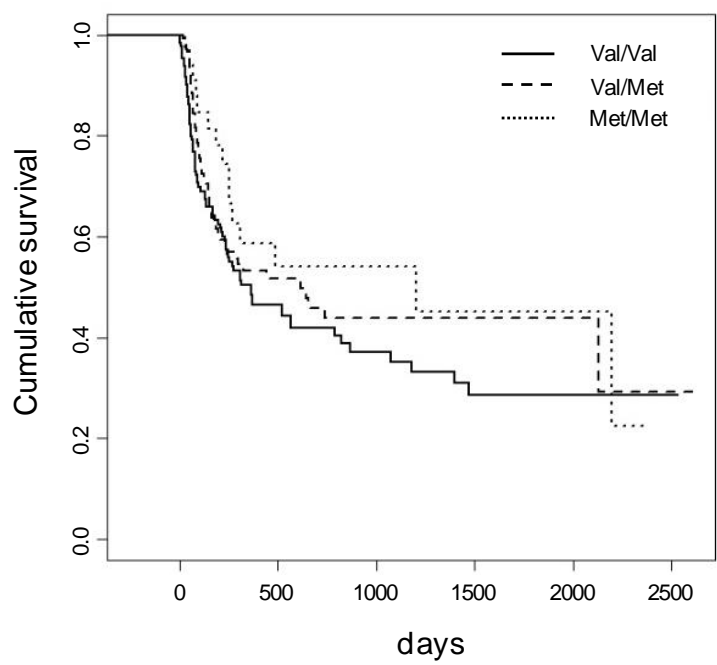

Figure 3.20: Cumulative survival according to the MICA-129 genotype.

(A) Kaplan-Meier survival curves of patients receiving a graft matched for the MICA-129 genotype $(n=274)$ are shown grouped according to their MICA-129 genotype. (B) Kaplan-Meier survival curves of all patients in the cohort $(n=320)$ are shown grouped according to their MICA-129 genotype. 


\section{Discussion}

\subsection{Different functional effects of the high and low avidity MICA- 129Met/Val variant on NK cell activity}

We showed that the MICA-129Met/Val polymorphism, causing a single amino acid substitution of Met by Val at position 129, affects the binding avidity of the activating NK cell receptor NKG2D confirming the previous report of Steinle and colleagues (Steinle et al., 2001). The amino acid 129 is located in the $\beta 4$ strand of the $\beta$-pleated sheet in the $\alpha 2$ domain of the MICA protein (Li et al., 1999; Li et al., 2001). It has been suggested that the replacement of Met by Val affects NKG2D binding indirectly by a conformational change instead of a direct participation in the MICA-NKG2D interface. The side chain of Met 129 is partially buried and forms hydrophobic interactions with the neighboring amino acids Glu 136, Ala 139 and Met 140 in the first $\alpha 2$ helical stretch, which may thus become differently positioned by the Val 129 substitution (Steinle et al., 2001).

Within our study, we used two experimental systems to analyze the MICA-129Met/Val and NKG2D interaction. Firstly, MICA-negative mouse fibroblast $\mathrm{L}$ tumor cells were stably transfected with pCMV6-AC-MICA-129Met/Val expression constructs encoding MICA variants, which differ only at position 129. Using these cells, we found a higher avidity of the MICA-129Met than MICA-129Val variant for NKG2D similarly as Steinle et al. (2001) did, who used stably MICA-transfected human C1R $B$ cell lines. Furthermore, we observed that the binding of NKG2D to the MICA-129Met isoform was more dependent on the intensity of MICA expression than binding to the MICA-129Val isoform.

Secondly, we produced the MICA-129Met/Val variants as recombinant mouse $\operatorname{lgG}_{2 a}-\mathrm{Fc}$ fusion proteins in HEK293 cells and analyzed their binding to the NKG2D receptor on primary human NK cells, stimulated for 4 days with $100 \mathrm{U} / \mathrm{ml}$ human IL-2. Surprisingly, we did not find a significantly different binding of these two MICA-129 isoforms to NKG2D. Also in SPR analysis both MICA-129-FC variants bound NKG2D with similar avidity. However, a tendency towards a higher NKG2D binding avidity of the MICA-129Met isoform was apparent.

Since the MICA-129-Fc fusion proteins were produced in human HEK293 cells, they were glycosylated as shown by digestion with the endoglycosidase Endo $\mathrm{H}$, which partly cleaves high mannose and some hybrid oligosaccharides from $\mathrm{N}$-linked glycoproteins. Three $\mathrm{N}$-linked glycosylation sites are present in the MICA $\alpha 1 \alpha 2$ domain (Asn 8, Asn 56 and Asn 102) (Steinle et al., 2001). Steinle and colleagues had compared MICA proteins produced in bacteria and in insect cells and found more stable complexes with recombinant NKG2D for the MICA proteins from insect cells suggesting that 
glycosylation enhanced the interaction with NKG2D (Steinle et al., 2001). They also compared the variants MICA*01 (with a Met at position 129) and MICA*04 (with a Val at position 129) produced in bacteria and found that only the MICA*01 was able to form a stable complex with NKG2D (Steinle et al., 2001). Thus, the glycosylation and/or conformation of the MICA molecules expressed on mouse L cells or produced as $\operatorname{lgG}_{2 a}-F c$ fusion proteins in human HEK293 cells might be slightly different leading to masking of the effect of the amino acid position 129 on NKG2D binding when the MICA-FC proteins were analyzed.

\subsubsection{NKG2D-mediated signaling}

Notably, the recombinant MICA-129Met/Val-mlgG $2 \mathrm{a}-\mathrm{Fc}$ fusion proteins varied in their efficacy to elicit downstream biological effects - similarly as MICA-129Met/Val molecules expressed on L cells despite having a comparable binding avidity to the NKG2D receptor of human primary NK cells. This strongly suggests that the functional difference of the MICA-129Met/Val dimorphism is not explainable alone by variations of NKG2D binding avidity. In addition, the MICA isoforms appear to vary also in their efficacy to transduce signals after binding to NKG2D. The structural basis of this difference remains to be elucidated.

The first alteration that we observed downstream of NKG2D binding was a faster and stronger phosphorylation of Src family kinases in NK cells stimulated by the immobilized MICA-129Met compared to the MICA-129Val isoform. This included the tyrosine residue Tyr419 (or Tyr416 when following the original nomenclature from chicken), which is auto-phosphorylated during activation (Irtegun et al., 2013). Activated Src family kinases are known to phosphorylate ITAMs which are present also in many natural killer receptor or adaptor molecules (Koch et al., 2013). Src family kinases are essential for NKG2D-trigged cytotoxicity in human NK cells although the signals are not transduced via an ITAM (Billadeau et al., 2003). NKG2D has no signaling motif within its short intracellular domain. In human NK cells, the NKG2D receptor associates with the DAP10 adaptor protein (or hematopoietic cell signal transducer, HCST) which carries a tyrosine-based YxxM motif in its cytoplasmic part (Wu et al., 1999). The adaptor DAP12, which can alternatively associate with mouse NKG2D, contains ITAMs. Their phosphorylation induces recruitment and activation of the spleen tyrosine kinase Syk or the $\zeta$-chain-associated protein of $70 \mathrm{kDa}$ (ZAP-70) tyrosine kinase leading to phosphorylation of downstream effectors which finally trigger effector cell activation. We did not find a phosphorylation of these kinases upon NKG2D stimulation. This is in agreement with 
findings that the NKG2D-DAP10 receptor complex, unlike ITAM-containing NK cell receptors, does not require Syk family or ZAP-70 tyrosine kinases for initiation of a downstream signaling cascade (Billadeau et al., 2003; Zompi et al., 2003; Chiesa et al., 2006).

Phosphorylated DAP10 recruits either the p85 subunit of PI3K and subsequently the small adaptor CrkL (Segovis et al., 2009) or Grb2 in association with the guanine nucleotide exchange factor VAV1 and SOS1 (Billadeau et al., 2003; Upshaw et al., 2006; Lanier, 2008). The latter event induces phosphorylation of the effector molecule SLP-76 and the phospholipase PLC- $\gamma 2$ (Upshaw et al., 2006). Through these signaling proteins, $\mathrm{Ca}^{2+}$-flux and cytoskeletal reorganization are induced resulting finally in cytotoxicity and cytokine secretion (Lanier, 2008; Long et al., 2013). However, probing of various blots with further phospho-specific Abs detecting molecules of underlying signaling pathways, including Abs for the p85 (Tyr458)/p55 (Tyr199) subunits of PI3K and the protein kinase Akt (Ser473) or VAV1 (Tyr174), SLP-76 (Tyr128) and PLC- $y 2$ (Tyr759), showed no detectable or only weak signals.

Interestingly, cytokine secretion, in contrast to cytotoxicity, was observed only after NKG2D crosslinking by NKG2D ligands, including MICA (Andre et al., 2004), but not by anti-NKG2D Abs (Billadeau et al., 2003; Andre et al., 2004) although this difference has been questioned recently (Lanier, 2008). In our experiments using MICA for cross-linking, the upstream event of NKG2D signaling - i.e. phosphorylation of Src family kinases - was clearly affected by the MICA-129Met/Val dimorphism. To demonstrate the relevance of this signaling step when using MICA to cross-link NKG2D instead of anti-NKG2D Abs, we utilized the specific Src family kinases inhibitor PP2 and showed that granule exocytosis was indeed completely abolished. The latter experiment suggested moreover that the different efficacies of the MICA-129Met and MICA-129Val variants to elicit NKG2D signaling resulted in different degrees of NK cell degranulation.

Taken together, the MICA-129Met/Val polymorphism does not only affect the binding avidity of NKG2D, both MICA isoforms appeared to differ also in their efficacy to trigger NKG2D-mediated signaling after binding to the immunoreceptor.

\subsubsection{NK cell cytotoxicity}

We tested the degranulation of human NK cells triggered by both recombinant MICA-129-Fc fusion proteins over a broad range of protein concentrations and found that the MICA-129Met variant was a significantly stronger inducer of NKG2D-mediated granule exocytosis than the MICA-129Val variant. 
For both variants the extend of NK cell degranulation increased up to protein concentrations of 10 or $20 \mu \mathrm{g} / \mathrm{ml}$. Afterwards it remained stable or even decreased. Similarly, also MICA-129Met ligands expressed on $L$ transfectants triggered significantly more granule exocytosis of human NK cells than MICA-129Val ligands in terms of CD107a cell surface expression intensity and proportion of CD107apositive NK cells. These experiments showed that the amount of degranulation was highly dependent on the MICA expression intensity on target cells only for the MICA-129Val variant. The expression intensity of MICA-129Met ligands, in contrast, had hardly any effect on the magnitude of NK cell degranulation.

The triggering of NKG2D signals by MICA ligands on target cells requires conjugate formation with NK cells and building of an immunological synapse. Thus, this situation represents the physiological conditions better than receptor stimulation by immobilized recombinant MICA ligands. To clarify further the effect of the MICA-129Met/Val dimorphism on the downstream point - i.e. killing of MICA-expressing target cells - we performed ${ }^{51} \mathrm{Cr}$ release assays. The MICA-129Met variant on $\mathrm{L}$ cells was also a significantly stronger trigger of NK cell cytotoxicity than the MICA-129Val variant. Notably, the expression intensity of the MICA-129Met variant had overall even a negative influence on the killing of target cells, whereas killing increased steadily with expression intensity of the MICA-129Val variant.

${ }^{51} \mathrm{Cr}$ release assays were not only performed with human LAK cells, which contain between $10 \%$ to $15 \%$ NK cells, but also with isolated human NK cells. Analysis revealed similar results but with reduced values for the relative cell lysis of MICA-expressing $L$ targets by isolated NK cells suggesting a better activation of NK cells by IL-2 in a co-culture with other PBMCs or an involvement of a further cell population. Besides expressing a $\gamma \delta$ TCR, human $\gamma \delta$ T cells also express the NKG2D receptor on their cell surface and do not necessarily need additional stimulation of other activating receptors, such as $\mathrm{CD}^{+} \alpha \beta$ T cells do, to be activated (Girardi et al., 2001; Whang et al., 2009). In addition to TCR-dependent recognition, activation of NKG2D-positive $\gamma \delta$ T cells by tumor cell-expressed NKG2D ligands can also trigger cytotoxic effector function (Wrobel et al., 2007). Since human $\gamma \delta$ T cells have been shown to lyse a broad range of epithelial tumor cells with the involvement of NKG2D ligands including MICA (Wrobel et al., 2007), this type of T cells might be involved in killing of the target cells in our experiments. For elucidation, further experiments have to be performed including cytotoxicity assays of isolated $\gamma \delta T$ cells and flow cytometric analyses of the degranulation of these effector cells after exposure to our MICA-129-expressing L cells. Although we have not investigated this $T$ cell subset so far, we assume that the MICA-129Met/Val dimorphism may also have an influence on the cytotoxic activity of $\gamma \delta$ T cells. 


\subsubsection{NKG2D-triggered cytokine release}

The functional effects of the MICA-129Met/Val polymorphism on NKG2D signaling were not restricted to NK cell cytotoxicity. Besides NK cell degranulation and target cell killing we also analyzed IFN- $\gamma$ secretion of purified IL-2-stimulated human NK cells co-cultured with MICA-129Met/Valexpressing $L$ target cells. Our experimental data revealed that the MICA-129Met variant was also a significantly stronger trigger of IFN- $\gamma$ release by NK cells than the MICA-129Val variant. Similarly to NK cell-mediated cytotoxicity, the amount of secreted IFN- $\gamma$ was also highly dependent on the MICA expression intensity on target cells only for the MICA-129Val but not for MICA-129Met variant.

This result is in agreement with a report by Yoshida et al. (2011) who used recombinant MICAglutathione S-transferase (GST)-fusion proteins to analyze IFN- $\gamma$ production from the human NK92MI cell line. They combined in their fusion proteins the MICA-129Met variant with the A9 variant of the transmembrane region and the MICA-129Val variant with the $A 5$ variant. The transmembrane region of MICA, encoded in exon 5, contains a triplet repeat microsatellite polymorphism $(G C T)_{n}$ in the transmembrane region, which varies in the number of alanine-encoding GCT repeats (Mizuki et al., 1997). The MICA ${ }^{129}$ Met;A9-GST protein induced more IFN- $\gamma$ release from the NK92MI cell line than the MICA ${ }^{129}$ Val;A5-GST protein (Yoshida et al., 2011). Thus, our results indicate that the MICA$129 \mathrm{Met} / \mathrm{Val}$ polymorphism is responsible for the varying IFN- $\gamma$ release of primary human NK cells.

\subsection{Influence of the MICA-129 dimorphism on MICA shedding and NKG2D counter-regulation}

Based on our findings regarding the influence of the MICA-129Met/Val polymorphism on functional effects of NK cells the following question came up: Why do the functional NK cell responses elicited by the MICA-129Met in contrast to the MICA-129Val variant not continuously increase with MICA expression intensity on target cells?

The MICA shedding phenomenon is thought to constitute a major counter-regulation mechanism of tumor cells to subvert NKG2D-mediated immunosurveillance (Waldhauer et al., 2008). Therefore, one possibility was that higher MICA expression leads to higher concentration of sMICA, which can inhibit NKG2D signaling by blocking or down-regulation of the receptor (Groh et al., 2002). However, our data showed that MICA-129Met/Val-transfected mouse $L$ cells did not shed MICA thus excluding the possibility that sMICA-129Met blocks NKG2D signaling more efficiently than sMICA-129Val in 
these experiments. Since several human tumor cell lines transfected with the MICA-129Met/Val expression constructs secreted higher amounts of sMICA compared to the corresponding wild type cell lines, the absence of MICA shedding in the L-MICA-129Met/Val transfectants is a feature of mouse $L$ cells and not a feature of the MICA-129Met/Val constructs. Moreover, first experiments using MICA-129Met/Val-expressing human Malme cells showed that the two MICA-129 variants varied in the amount of released SMICA, whereat the MICA-129Met variant exhibited increased MICA shedding compared to the MICA-129Val variant. This may indicate an influence of the MICA-129 dimorphism on the shedding of this NKG2D ligand, possibly mediated by a conformational change.

Besides soluble NKG2D ligands, such as SMICA, also sustained exposure of NK cells to NKG2D ligandexpressing cells can down-regulate the immunoreceptor NKG2D (Coudert et al., 2005; Oppenheim et al., 2005; Wiemann et al., 2005). Therefore, we also investigated whether the MICA-129 dimorphism has an impact on NKG2D expression of IL-2-stimulated human NK cells exposed to L-MICA129Met/Val target cells, since this might potentially result in enhanced down-modulation of NKG2D on NK cells after exposure to the MICA-129Met variant. Indeed, we found a stronger downregulation of NKG2D on NK cells exposed to L-MICA-129Met than L-MICA-129Val target cells. This is in accordance with the finding of Yoshida et al. showing that the MICA ${ }^{129}$ Met;A9-GST fusion protein reduced the NKG2D expression on human NK92MI cells more than the MICA ${ }^{129}$ Val;A5-GST protein (Yoshida et al., 2011). Hence, the explanation for the fact that an enhanced expression of the MICA129Met in contrast to the Val variant of the MICA-129-transfected L cells did not result in continuously stronger functional NK cell responses seems to be an increased NKG2D down-regulation on NK cells exposed to this variant.

Taken together all experimental data, our findings showed that the MICA-129 dimorphism is functionally relevant and fine-tunes NK cell activity (Figure 4.1). The MICA-129Met isoform was functionally characterized by higher NKG2D binding avidity, stronger and faster NKG2D signaling, triggering of more NK cell cytotoxicity, including granule exocytosis and target cell lysis, and IFN- $\gamma$ release but also increased NKG2D down-regulation on NK cells. Notably, the degree of NK cellmediated cytotoxicity and cytokine production increased steadily with the MICA expression intensity, if the MICA-129Val variant was present on target cells. Augmented expression of the MICA-129Met isoform, in contrast, had no or even a negative effect on NK cell function. These data demonstrate a strong interdependency of the MICA expression intensity and the MICA-129 genotype. Furthermore, the stronger capacity of the high avidity MICA-129Met variant to signal via NKG2D itself seems to limit the biological effects of an increased MICA expression intensity by NKG2D counter-regulation. 

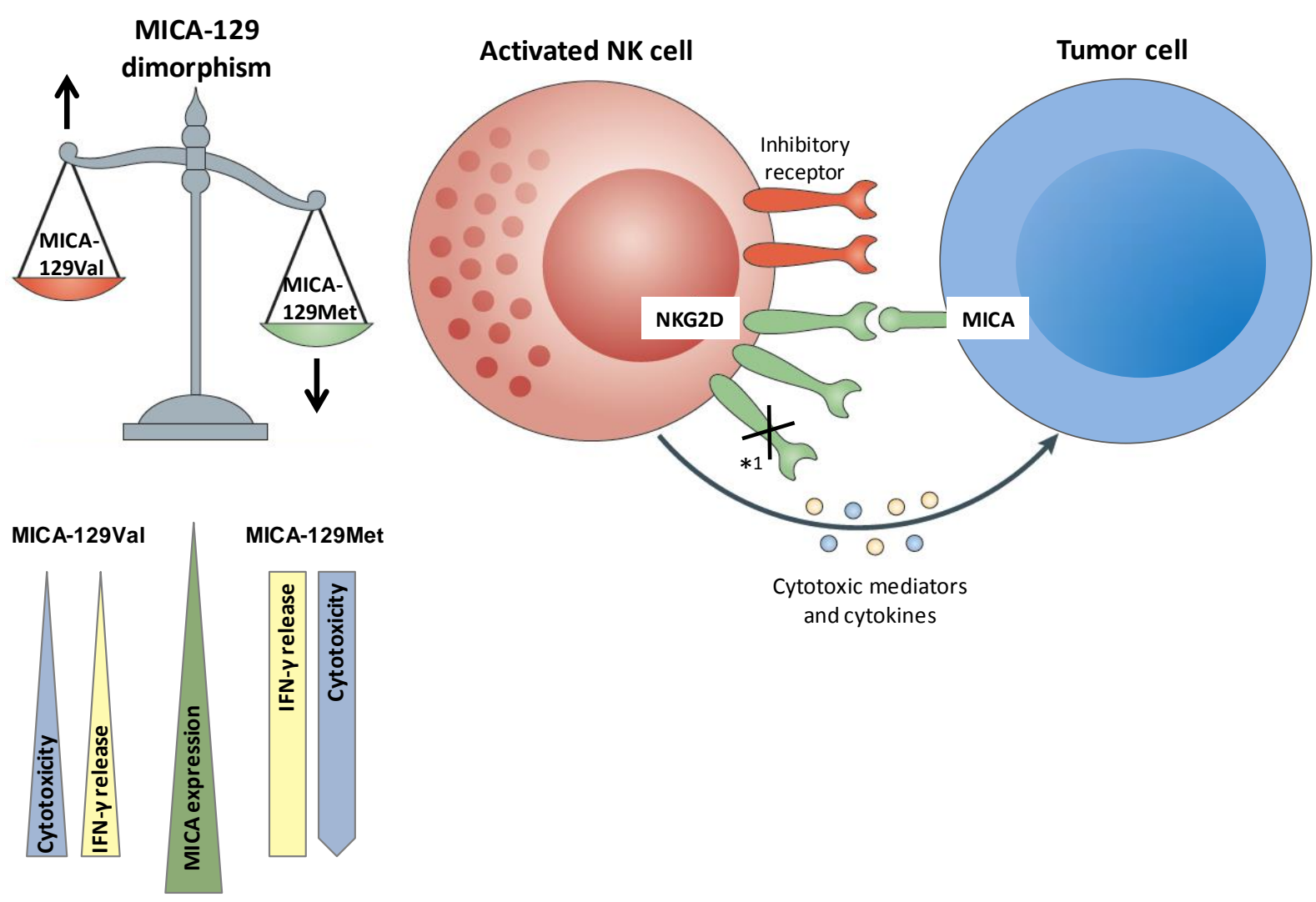

$$
\text { and cytokines }
$$
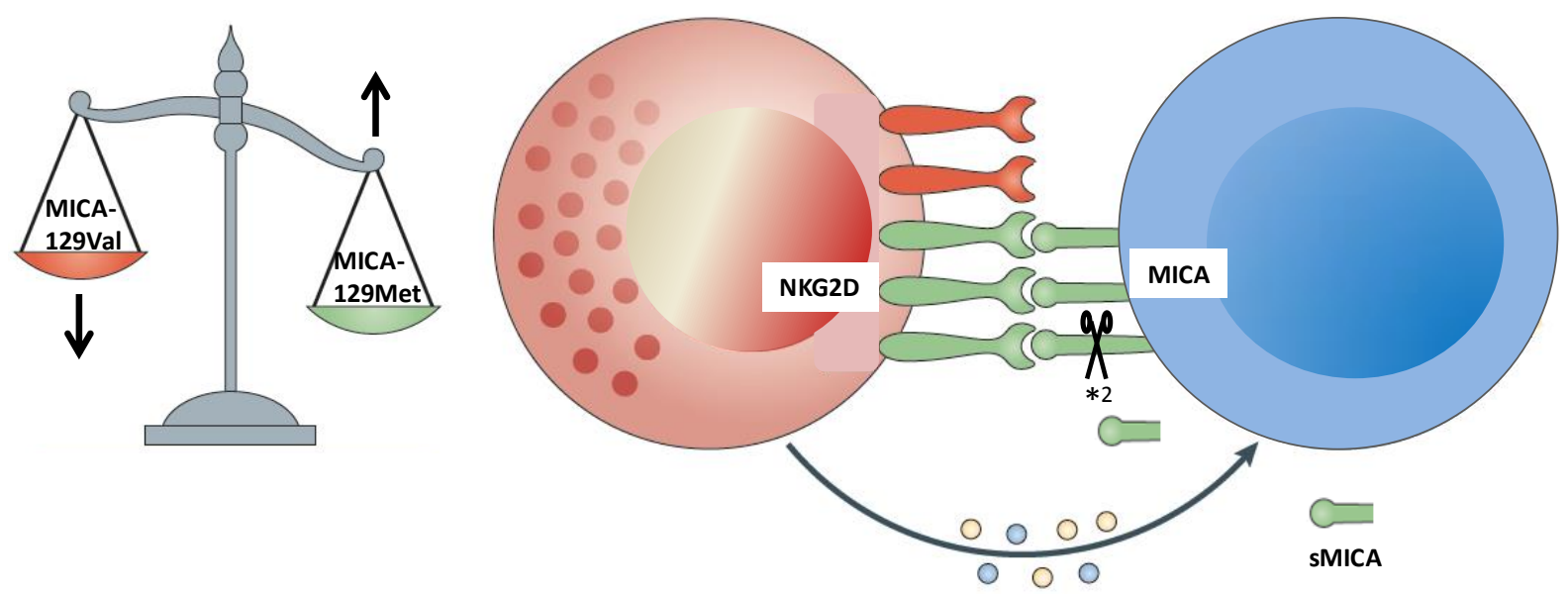

Figure 4.1: Functional effects of the MICA-129Met/Val dimorphism on NK cell activity and tumor-associated counter-regulation mechanisms.

The MICA-129Met/Val dimorphism is functionally relevant and fine-tunes NK cell activity. Especially at low MICA expression intensity (upper panel), the high avidity MICA-129Met variant has stronger functional effects, including triggering of more NK cell cytotoxicity and IFN- $p$ release, than the MICA-129Val variant. However, at high expression levels (lower panel), the low avidity MICA-129Val variant gains advantages. For this variant, the degree of NK cell-mediated cytotoxicity and cytokine production increase steadily with the MICA expression intensity. In contrast, augmented expression of the MICA-129Met variant has no or even a negative effect on NK cell function. This demonstrates a strong interdependency of the MICA expression intensity and the MICA129 genotype. Moreover, the MICA-129Met variant is associated also with increased NKG2D down-regulation on NK cells $\left(*^{1}\right)$ and MICA shedding from tumor cells $\left(*^{2}\right)$. Thus, the stronger capacity of the MICA-129Met variant to signal via NKG2D itself seems to limit the biological effects of an increased MICA expression intensity by tumor-associated counter-regulation mechanisms (Adapted from Vivier et al., 2012). 


\subsection{Association of the MICA-129 dimorphism with the outcome of HSCT}

Allogeneic HSCT offers an option to cure several hematological diseases. Depending on the disease entity, 5-year-survival rates vary, with limitations imposed by severe post-transplant complications such as GVHD, relapse of malignancy and infection (Dickinson, 2008). HLA matching is mandatory to reduce the risk of graft rejection and GVHD, however minor histocompatibility antigens (mHags) also can affect transplant outcome playing a role in both GVHD and GVL mechanisms (Warren et al., 2012). Moreover, an increasing number of studies in the last 15 years have demonstrated the impact of SNPs on the outcome of HSCT (Dickinson, 2008). For instance, SNPs in the TNF- $\alpha$ gene have been associated with an increased risk of GVHD and some of them lead to increased expression of this proinflammatory cytokine, which might explain the observed association with GVHD (Dickinson, 2008). Furthermore, polymorphisms of NK cell receptors, such as KIRs (Cooley et al., 2009; Venstrom et al., 2010), have been shown to play a role in HSCT, thereby suggesting a link between NK responses and GVHD (Moretta et al., 2009). Those SNPs, which alter the regulation of genes or the function of proteins, might not only be useful to predict risks; they might also identify pathophysiological pathways, which could be targeted by new therapeutics.

In this study, we focused on the MICA-129Met/Val dimorphism, which has been associated previously with the risk of cGVHD and relapse after HSCT (Boukouaci et al., 2009). The polymorphism could potentially be causative for the observed disease association due to a higher avidity of MICA129Met than MICA-129Val variants to NKG2D. Additionally, we found that the degree of NK cell cytotoxicity and cytokine production increased steadily with the MICA expression intensity, if the MICA-129Val variant was present on target cells. Augmented expression of the MICA-129Met isoform, in contrast, had no or even a negative effect on NK cell function. This interaction between MICA-129 genotype and MICA expression intensity has to our knowledge not been noticed before but is likely highly important when interpreting MICA-129 disease associations.

Analysis of the cohort undergoing allogeneic HSCT in the University Medical Center in Göttingen revealed an increased probability of survival after HSCT for carriers of MICA-129Met variants. The homozygous MICA-129Met/Met carriers had an increased risk to experience aGVHD, however MICA129 Met variants conferred also a lower probability to die due to this complication. Since this association was observed not only in the whole cohort but also in the subgroup of patients receiving a graft matched for the MICA-129 genotype, the MICA-129 dimorphism is apparently not important as a mHag but likely due to its biological effects on NKG2D signaling. 
Taken together, the presence of MICA-129Met variants appeared to augment GVL and GVH reactions. MICA-129Met variants, especially in homozygous carriers, seemed to support initiation of aGVHD but also to limit the severity of this complication. It has been reported previously that the risk of developing cGVHD was increased for recipients with the MICA-129Val/Val genotype and the risk of relapse was increased for the MICA-129Met/Met genotype (Boukouaci et al., 2009). Thus, the SNP MICA-129 was significantly associated with the outcome of HSCT in two independent cohorts, however it was predictive for different outcome parameters. This could be due to differences in the clinical cohorts, such as different clinical and treatment characteristics, but it could also point towards confounding factors such as expression intensity, which modulate the biological effect of this SNP and need to be taken into account.

In view of the expression pattern of MICA and NKG2D, the MICA-129 dimorphism could affect several cell types and pathophysiological pathways after transplantation. MICA is constitutively expressed in gastrointestinal epithelium (Groh et al., 1996), i.e. a target organ of GVHD. This stress-inducible NKG2D ligand can be up-regulated in many other tissues under conditions of inflammation (Raulet et al., 2013), which occur regularly after pre-conditioning. MICA/B was indeed found in skin and liver during aGVHD (Gannage et al., 2008). MICA is also expressed on many malignancies (Champsaur and Lanier, 2010; Choy and Phipps, 2010; Raulet et al., 2013), including leukemias (Salih et al., 2003; Sconocchia et al., 2005; Boissel et al., 2006; Kato et al., 2007; Diermayr et al., 2008; Nückel et al., 2010; Sanchez-Correa et al., 2011; Hilpert et al., 2012) and lymphomas (Dulphy et al., 2009; Reiners et al., 2013), however the expression intensities and the amounts of sMICA in patient sera were variable (Salih et al., 2002; Sconocchia et al., 2005; Boissel et al., 2006; Nückel et al., 2010; Hilpert et al., 2012). In a recent study including 205 patients, the majority of leukemias were positive for MICA (AML 53\%, ALL 65\%, CML 33\% and CLL 61\%) and MICA was the most frequently detected NKG2D ligand especially among acute leukemias but with quite variable expression intensities (Hilpert et al., 2012). Hence, it is conceivable that the variable MICA expression level on malignant cells modifies the effect of the MICA-129 SNP. Notably, also sMICA was detected most frequently and in high amounts in acute leukemias (Hilpert et al., 2012).

In cancer, the interaction of NKG2D with MICA should activate antitumor NK cell responses but the immunoreceptor is down-regulated when associated with circulating tumor-derived sMICA (Groh et al., 2002; Kaiser et al., 2007). Several clinical studies have shown an association between tumorassociated or soluble NKG2D ligands and disease progression and poor prognosis in different malignancies, including pancreatic and prostate cancer (MICA and MICB) (Wu et al., 2004; Duan et al., 2011), ovarian cancer (ULBP2 and ULBP4) (Li et al., 2009), melanoma (ULBP2) (Paschen et al., 
2009) and multiple myeloma (MICA) (Rebmann et al., 2007). For instance, elevated sMICA plasma levels in high-risk neuroblastoma patients treated with allogeneic IL-2-stimulated NK cells after haplo-identical SCT correlated with impaired NK cell cytotoxicity and showed the influence of shed ligand on tumor immune evasion (Kloess et al., 2010). Moreover, MICA polymorphisms are associated with several diseases related to NK cell activity, such as infection, malignancy, autoimmune disease, graft rejection and GVHD. Underlying mechanisms include NK cell-mediated cytotoxicity as well as MICA shedding producing immunosuppressive sMICA (Choy and Phipps, 2010). It has been reported, e.g., that the MICA-129Val/Val genotype was more frequent in ulcerative colitis patients and that these patients had also higher sMICA levels compared to those with the Met/Val or Met/Met genotype (Zhao et al., 2011). In the HSCT cohort described by Boukouaci and colleagues, the MICA-129Val/Val genotype and increased serum levels of sMICA after HSCT were independently associated with the incidence of CGVHD, i.e. MICA-129 genotypes and SMICA serum levels exerted an independent but additive effect on the cGVHD incidence (Boukouaci et al., 2009). Patients carrying the $\mathrm{Val} / \mathrm{Val}$ genotype and having sMICA level greater than $80 \mathrm{pg} / \mathrm{ml}$ were at high risk of developing cGVHD, whereas the lowest risk was observed for patients with the Met/Met or Met/Val genotype in combination with sMICA level below $80 \mathrm{pg} / \mathrm{ml}$ (Boukouaci et al., 2009). Our analysis of the shedding of MICA-129Met/Val-expressing human Malme cells showed that the MICA-129Met variant exhibited increased MICA shedding compared to the MICA-129Val variant. Furthermore, we found that the MICA shedding was dependent on the MICA expression intensity indicating again the importance of the MICA expression level for data interpretation. Altogether, sMICA appears to be a further factor, which modulates the biological effect of this SNP. Moreover, the presence of anti-MICA Abs before transplantation in the cohort described by Boukouaci et al. (2009) was associated with protection against CGVHD. This inverse relationship between anti-MICA Abs and sMICA suggests an antibodybased neutralization of deleterious effects of sMICA (Boukouaci et al., 2009).

After HSCT, NK cells contribute to GVL effects, provide protection against certain pathogens such as cytomegalovirus and appear to reduce GVHD (Ruggeri et al., 2002; Leung, 2011; Babor et al., 2013; Palmer et al., 2013). Alloreactive donor NK cells contribute to preventing the occurrence of GVHD and graft rejection by killing also recipient APCs and CTLs alongside malignant cells (Locatelli et al., 2013). Parts of these effects could be mediated by recognizing of NKG2D ligands including MICA. However, the overall effect of NKG2D signaling on aGVHD is not clear. Hence, MICA variants eliciting more NK cell cytotoxicity and cytokine release might confer advantages especially with respect to the eradication of malignant cells and the limitation of virus infections. MICA-129Met variants triggering faster and stronger NKG2D responses, presumably contribute to the occurrence of aGVHD as 
observed in our homozygous carriers of MICA-129 variants. The severity of aGVHD, however, might be limited due to a faster and stronger NKG2D counter-regulation resulting in a lower risk to die from this complication. In our HSCT cohort, the MICA-129Val/Val genotype was associated with an increased risk of death due to aGVHD. Inversely, in the cohort described by Boukouaci et al. (2009) the $\mathrm{Val} / \mathrm{Val}$ genotype was associated with an increased incidence of cGVHD. This might be linked to lesser NKG2D down-regulation elicited by the Val/Val genotype which in turn might lead to sustained NK cell activity in contrast to the stronger down-modulated NK cell responses triggered by MICA129Met variants. In parallel, carriers of MICA-129Met variants might profit initially from stronger GVL effects but of limited duration resulting in a higher risk of relapse in homozygous carriers as observed in the before mentioned HSCT cohort (Boukouaci et al., 2009).

Our data showed that the MICA-129Met variant triggers more NK cell activity at low expression intensities, whereas the MICA-129Val variant gains advantages at high expression, at which the MICA-129Met variant already down-regulates NKG2D leading to impaired NK cell function. Both variants may confer advantages and disadvantages in certain situations, such as virus infections, suggesting balancing evolution of MICA alleles. Differences in MICA expression levels in GVHDaffected tissues (Gannage et al., 2008) and on malignant cells (Sconocchia et al., 2005; Boissel et al., 2006; Nückel et al., 2010; Hilpert et al., 2012) could further explain why the SNP was associated with different outcomes in our cohort and the previously investigated cohort (Boukouaci et al., 2009). The situation becomes even more complicated by sMICA (Boukouaci et al., 2009), which can block NKG2D-mediated cytotoxicity and down-regulate NKG2D on NK cells. Although the MICA-129Val/Val genotype and elevated SMICA serum levels after HSCT were independently associated with the incidence of CGVHD, sMICA seems to be a modifying factor (Boukouaci et al., 2009). A further level of complexity is added by anti-MICA Abs (Boukouaci et al., 2009), which can neutralize sMICA but also sensitize MICA expressing cells to complement-dependent cellular cytotoxicity and therefore appear to modulate the effects of the SNP MICA-129 (Zou et al., 2002; Jinushi et al., 2006; Zou and Stastny, 2010).

Besides cytotoxicity, NKG2D-mediated signaling in NK cells triggers also release of cytokines, which modulate further immune reactions. IFN- - , e.g., can up-regulate HLA class I molecules and thereby aggravate T cell-mediated GVHD. Moreover, not only NK cells but also several T cell subtypes, including $\mathrm{CD}^{+} \alpha \beta$ T cells and $\gamma \delta$ T cells, express NKG2D. In addition to TCR-dependent recognition, activation of $\gamma \delta T$ cells by NKG2D ligands can also elicit cytotoxic effector functions. It has been shown that the lysis of several epithelial tumors, such as melanomas, pancreatic adenocarcinomas, 
squamous cell carcinomas and lung carcinoma, by human $\gamma \delta T$ cells involves the NKG2D pathway (Wrobel et al., 2007). Their ability to display potent anti-tumor activity against leukemias among other malignancies and the fact that these cells do not cause GVHD make $\gamma \delta$ T cells to be considered as a promising tool for tumor immunotherapy in the context of allogeneic HSCT (Locatelli et al., 2013). Thus, NKG2D-mediated co-stimulation of $\mathrm{CD}^{+} \alpha \beta$ T cells and stimulation of $\gamma \delta \mathrm{T}$ cells could contribute to GVH or GVL reactions, respectively. Although we have not investigated T cells in our study, we assume that the MICA-129Met/Val dimorphism affects the strength and kinetics of NKG2D signaling also in these cell types.

In conclusion, we have shown that the MICA-129Met/Val polymorphism has a significant impact on the outcome of HSCT. We have demonstrated that it affects the strength and kinetics of NKG2D signaling resulting in differences of NK cell cytotoxicity and cytokine secretion but also NKG2D counter-regulation suggesting that the MICA-129 dimorphism directly affects the outcome of HSCT. Important factors, which modulate the effects of this SNP, are the MICA expression intensity as shown here but also sMICA and anti-MICA Abs as shown previously (Boukouaci et al., 2009). The SNP MICA-129 could be highly informative for the prediction of the outcome of HSCT but likely the confounding factors have to be considered carefully. The SNP could also be predictive for the success of other immunotherapies, e.g., adoptive NK cell transfer, using NK cells to treat MICA-positive malignancies (Leung, 2011; Vivier et al., 2012). Moreover, this might be highly relevant when NKG2D signaling is targeted by new therapies aiming at up-regulation of MICA by histone deacetylase (HDAC) inhibitors (Kato et al., 2007; Diermayr et al., 2008) or blocking of signaling by soluble NKG2D (Hilpert et al., 2012).

\subsection{Open questions - MICA-129 gene expression and adoptive NK cell transfer}

During our experiments, the question came up whether the MICA-129Met/Val polymorphism also has an influence on the MICA gene expression level. Regarding this our first experiments showed a difference in the MICA mRNA expression level but no significant difference in the MICA cell surface expression between MICA-transfected mouse L cells of both MICA-129 variants. The data suggest that for the MICA-129Met variant higher amounts of MICA mRNA are required for a high MICA protein expression compared to the MICA-129Val variant. Additionally, the MICA protein expression 
appears to be more directly dependent on the MICA gene expression level for the MICA-129Val than the Met variant.

Because of these observations we furthermore genotyped 12 human melanoma and 3 breast carcinoma cell lines for the MICA-129 dimorphism and determined the MICA mRNA levels (see Appendix, Table A.1). For the qRT-PCRs, Gapdh (glyceraldehyde 3-phosphate dehydrogenase) was chosen as housekeeping gene for normalization of mRNA amounts. Human erythroleukemia K562 cells, which express MICA, were used as reference cell line and the mRNA expression in this cell line was set to 1 . Amounts of MICA mRNA in the melanoma and breast carcinoma cell lines were quantified relative to those of the K562 cells. Treatment of the cells with the HDAC inhibitor SAHA resulted in an increase of the MICA mRNA amount of all cell lines compared to their untreated counterparts (Table A.1). However, on the basis of these 15 investigated human tumor cell lines it is not possible to make a statement whether an association exists between the MICA-129 genotype and the MICA gene expression level because of the small number of cell lines which were homozygous, especially for the MICA-129Met variant.

One aim of our study was to investigate whether the MICA-129 dimorphism has an influence on the therapeutic efficacy of an experimental adoptive immunotherapy of cancer with activated human NK cells using immunodeficient mouse models.

Preliminary in vivo experiments, in which various clones of MICA-129Met/Val-expressing L cells were s.c. injected into immunodeficient C57BL/6- $\mathrm{Rag}^{-1-} / \mathrm{cpc}^{-/-}$mice, lacking $\mathrm{B}, \mathrm{T}$ and NK cells, revealed different tumor growth rates. However, to answer the question it is important to use MICAexpressing tumor cells of both MICA-129 variants with similar tumor growth rates for the experiments. A further important factor which has to be taken into account is the MICA cell surface expression of L-MICA-129-expressing cells used for future experiments, since the MICA expression intensity affects NK cell-mediated cytotoxicity and IFN- $\gamma$ secretion as shown in our in vitro experiments. To avoid clonal effects the production of comparable cell populations of each MICA-129 variant using a retroviral infection system could be conceivable.

In a pilot study, after s.c. injection of MICA-129Met/Val-expressing L tumor cells into immunodeficient $\mathrm{C} 57 \mathrm{BL} / 6-\mathrm{Rag}^{-1} / \mathrm{Cpc}^{-/-}$mice, the animals were i.v. inoculated with IL-2-stimulated human NK cells. Since it was not possible to detect the transferred NK cells in different taken tissues after autopsy (day 19-39) and since there was no difference in the lifespan between animals treated with NK cells or the PBS control, it seems that the NK cells did not survive long enough in the mice to reveal antitumor effects. Possible reasons therefore could be an insufficient pre-activation of NK cells 
in vitro as shown previously for C57BL/6 mouse NK cells by Ni et al. (2012) or missing stimulation in vivo with cytokines such as IL-2.

Taken together, these preliminary in vivo experiments indicate that it is necessary to further optimize the in vitro stimulation of NK cells and the adoptive NK cell transfer protocol to obtain prolonged NK cell survival and vigorous NK cell activity. For additional NK cell pre-activation, e.g., besides IL-2 the three cytokines IL-12, IL-15 and IL-18 could be added to the NK cells co-cultured together with other PBMCs. It could be also considered to transfer the stimulated human NK cells to tumor-bearing mice which already reveal established tumor growth. Furthermore, rhIL-2 could be administered in parallel to the adoptive NK cell transfer as well as at later time points to improve the survival and function of the transferred NK cells in vivo.

Previous studies of our research group showed also that mouse C.B.-17/Ztm-scid NK cells can kill MICA/B-expressing human melanoma cells in vitro and that HSP70 and inducible NKG2D ligands, such as MICA, synergistically promote the activation of mouse NK cells resulting in a reduced tumor growth and suppression of metastatic disease (Elsner et al., 2007). Based on these findings, it could be investigated whether NK cells of C.B.-17/Ztm-scid or C57BL/6-Rag2 ${ }^{-/-}$mice, which do not possess B and T cells but still have functional NK cells, can efficiently recognize and kill MICA-expressing tumors after injection of L-MICA-129 cells. If this would be the case, the next step would be to analyze whether the MICA-129 dimorphism also has an impact on the NK cell-mediated activity in vivo. 


\section{Summary and Conclusions}

Several studies within the last 15 years have demonstrated the impact of SNPs on the outcome of HSCT. Those SNPs, which alter the regulation of genes or the function of proteins, might not only be useful to predict risks they might also identify new targets for therapy. In this study, we focused on the MICA-129Met/Val polymorphism which has been associated previously with the risk of cGVHD and could be causative itself due to a higher avidity of MICA-129Met than MICA-129Val variants to NKG2D. To validate the biological relevance of the MICA-129 dimorphism, we evaluated whether this SNP affects NKG2D-mediated signaling and NK cell functions, including cytotoxicity and cytokine release, and whether it is associated with the outcome of allogeneic HSCT.

Using transfected cell lines and recombinant proteins for both variants we showed that the MICA129Met isoform was characterized by higher NKG2D binding avidity, faster and stronger NKG2D signaling, triggering of more NK cell cytotoxicity and IFN-y release. At low MICA expression intensity, the Met variant had stronger functional effects than the Val variant. However, the degree of NK cell cytotoxicity and cytokine production increased steadily with expression intensity of the MICA-129Val variant, whereas an enhanced expression of the MICA-129Met isoform had no or even a negative effect on NK cell function. These data demonstrated a strong interdependency of the MICA expression intensity and the MICA-129 genotype. Since the functional NK cell responses elicited by the MICA-129Met in contrast to the MICA-129Val variant did not continuously increase with MICA expression intensity on target cells, we analyzed counter-regulation mechanisms such as tumor cellmediated MICA shedding and NKG2D down-regulation of NK cells. We could exclude the possibility that sMICA-129Met blocks NKG2D signaling more efficiently than sMICA-129Val in these experiments, since MICA-129Met/Val-transfected mouse L cells did not shed MICA. However, the MICA-129Met variant down-regulated NKG2D more efficiently than the MICA-129Val variant. Moreover, experiments with MICA-129Met/Val-expressing human Malme cells suggested that the MICA-129Met variant exhibited also increased MICA shedding. In summary, our data demonstrate that the MICA-129Met/Val polymorphism is functionally relevant and fine-tunes NK cell activity. The effect of this SNP depends on the MICA expression intensity and the generally stronger signaling capacity of the MICA-129Met variant is compromised or even inverted at higher MICA expression intensities.

To elucidate whether the differences between the MICA variants are indeed clinically relevant, the MICA-129 dimorphism was determined in a cohort of patients undergoing allogeneic HSCT in the Department of Hematology and Medical Oncology at the University Medical Center Göttingen (320 genotyped P/D pairs with clinical characteristics). In recipients matched on the MICA-129 genotype, 
MICA-129Met variants increased the chance of survival and reduced the risk to die due to aGVHD, although homozygous carriers had an increased risk to experience this complication after HSCT. Thus, the presence of the high avidity variant of MICA-129 may lead to a favorable outcome of HSCT due to initially stronger NKG2D signaling followed, however, by a more rapid NKG2D counter-regulation. In conclusion, we have confirmed that the MICA-129Met/Val dimorphism has a significant impact on the outcome of allogeneic HSCT. We have shown that it affects the strength and kinetics of NKG2D signaling resulting in differences of NK cell cytotoxicity and cytokine secretion but also NKG2D counter-regulation suggesting that the MICA-129 dimorphism directly affects the outcome of HSCT. Important factors, which modulate the effects of this SNP, are the MICA expression intensity but also sMICA and anti-MICA Abs. Thus, the SNP MICA-129 could be highly informative for the prediction of the outcome of allogeneic HSCT but the MICA expression intensity has likely to be considered. Moreover, the data suggest that new therapy regimens aiming at an up-regulation of MICA to improve tumor cell killing by NK cells might be beneficial only for carriers of the MICA-129Val variant. 


\section{References}

Aktas E, Kucuksezer UC, Bilgic S, Erten G, Deniz G. Relationship between CD107a expression and cytotoxic activity. Cell Immunol. 2009;254(2):149-54.

Alici E. IPH-2101, a fully human anti-NK-cell inhibitory receptor mAb for the potential treatment of hematological cancers. Curr Opin Mol Ther. 2010;12(6):724-33.

Alter G, Malenfant JM, Altfeld M. CD107a as a functional marker for the identification of natural killer cell activity. J Immunol Methods. 2004;294(1-2):15-22.

Amroun $H$, Djoudi $H$, Busson $M$, Allat R, El Sherbini SM, Ramasawmy R, Brun M, Dulphy $N$, Krishnamoorthy R, Toubert A, Charron D, Abbadi MC, Tamouza R. Early-onset ankylosing spondylitis is associated with a functional MICA polymorphism. Hum Immunol. 2005;66(10):1057-61.

Anderson E, Grzywacz B, Wang H, Wang T, Haagenson M, Spellman S, Blazar BR, Miller JS, Verneris MR. Limited role of MHC class I chain-related gene A (MICA) typing in assessing graft-versus-host disease risk after fully human leukocyte antigen-matched unrelated donor transplantation. Blood. 2009;114(21):4753-4754; author reply 4754-5.

Andre $\mathrm{P}$, Castriconi R, Espeli M, Anfossi N, Juarez T, Hue S, Conway H, Romagne F, Dondero A, Nanni M, Caillat-Zucman S, Raulet DH, Bottino C, Vivier E, Moretta A, Paul P. Comparative analysis of human NK cell activation induced by NKG2D and natural cytotoxicity receptors. Eur I Immunol. 2004;34(4):961-71.

Anfossi N, Andre P, Guia S, Falk CS, Roetynck S, Stewart CA, Breso V, Frassati C, Reviron D, Middleton $D$, Romagne $F$, Ugolini $S$, Vivier E. Human NK cell education by inhibitory receptors for MHC class I. Immunity. 2006;25(2):331-42.

Armeanu S, Bitzer M, Lauer UM, Venturelli S, Pathil A, Krusch M, Kaiser S, Jobst J, Smirnow I, Wagner A, Steinle A, Salih HR. Natural killer cell-mediated lysis of hepatoma cells via specific induction of NKG2D ligands by the histone deacetylase inhibitor sodium valproate. Cancer Res. 2005;65(14):63219.

Armeanu S, Krusch M, Baltz KM, Weiss TS, Smirnow I, Steinle A, Lauer UM, Bitzer M, Salih HR. Direct and natural killer cell-mediated antitumor effects of low-dose bortezomib in hepatocellular carcinoma. Clin Cancer Res. 2008;14(11):3520-8.

Ashkenazi A, Dixit VM. Death receptors: signaling and modulation. Science. 1998;281(5381):1305-8.

Babor F, Fischer JC, Uhrberg M. The role of KIR genes and ligands in leukemia surveillance. Front Immunol. 2013;4:27.

Bahram S, Bresnahan M, Geraghty DE, Spies T. A second lineage of mammalian major histocompatibility complex class I genes. Proc Natl Acad Sci U S A. 1994;91(14):6259-63.

Bahram S. MIC genes: from genetics to biology. Adv Immunol. 2000;76:1-60. 
Bauer S, Groh V, Wu J, Steinle A, Phillips JH, Lanier LL, Spies T. Activation of NK cells and T cells by NKG2D, a receptor for stress-inducible MICA. Science. 1999;285(5428):727-9.

Benson DM, Padmanabhan S, Hofmeister CC, Bakan CE, Abonour R, Suvannasankha A, Efebera YA, Squiban PJ, Caligiuri MA, Farag S. A phase I study of IPH2101, a novel anti-inhibitory KIR monoclonal antibody, in patients with multiple myeloma. J Clin Oncol. 2010;28(15S):8139.

Billadeau DD, Upshaw JL, Schoon RA, Dick CJ, Leibson PJ. NKG2D-DAP10 triggers human NK cellmediated killing via a Syk-independent regulatory pathway. Nat Immunol. 2003;4(6):557-64.

Boissel N, Rea D, Tieng V, Dulphy N, Brun M, Cayuela JM, Rousselot P, Tamouza R, Le Bouteiller P, Mahon FX, Steinle A, Charron D, Dombret H, Toubert A. BCR/ABL oncogene directly controls MHC class I chain-related molecule A expression in chronic myelogenous leukemia. J Immunol. 2006;176(8):5108-16.

Boukouaci W, Busson M, Peffault de Latour R, Rocha V, Suberbielle C, Bengoufa D, Dulphy N, Haas P, Scieux C, Amroun H, Gluckman E, Krishnamoorthy R, Toubert A, Charron D, Socie G, Tamouza R. MICA-129 genotype, soluble MICA, and anti-MICA antibodies as biomarkers of chronic graft-versushost disease. Blood. 2009;114(25):5216-24.

Braud VM, Allan DS, McMichael AJ. Functions of nonclassical MHC and non-MHC-encoded class I molecules. Curr Opin Immunol. 1999;11(1):100-8.

Brown MG, Fulmek S, Matsumoto K, Cho R, Lyons PA, Levy ER, Scalzo AA, Yokoyama WM. A 2-Mb YAC contig and physical map of the natural killer gene complex on mouse chromosome 6 . Genomics. 1997;42(1):16-25.

Bryceson YT, March ME, Barber DF, Ljunggren HG, Long EO. Cytolytic granule polarization and degranulation controlled by different receptors in resting NK cells. J Exp Med. 2005;202(7):1001-12.

Bryceson YT, March ME, Ljunggren HG, Long EO. Synergy among receptors on resting NK cells for the activation of natural cytotoxicity and cytokine secretion. Blood. 2006;107(1):159-66.

Bryceson YT, Ljunggren HG, Long EO. Minimal requirement for induction of natural cytotoxicity and intersection of activation signals by inhibitory receptors. Blood. 2009;114(13):2657-66.

Burgess SJ, Marusina Al, Pathmanathan I, Borrego F, Coligan JE. IL-21 down-regulates NKG2D/DAP10 expression on human NK and CD8+ T cells. J Immunol. 2006;176(3):1490-7.

Burshtyn DN, Scharenberg AM, Wagtmann N, Rajagopalan S, Berrada K, Yi T, Kinet JP, Long EO. Recruitment of tyrosine phosphatase $\mathrm{HCP}$ by the killer cell inhibitor receptor. Immunity. 1996;4(1):77-85.

Carrega P, Morandi B, Costa R, Frumento G, Forte G, Altavilla G, Ratto GB, Mingari MC, Moretta L, Ferlazzo G. Natural killer cells infiltrating human nonsmall-cell lung cancer are enriched in CD56 bright CD16(-) cells and display an impaired capability to kill tumor cells. Cancer. 2008;112(4):863-75.

Cartron G, Dacheux L, Salles G, Solal-Celigny P, Bardos P, Colombat P, Watier H. Therapeutic activity of humanized anti-CD20 monoclonal antibody and polymorphism in IgG Fc receptor FcgammaRIIla gene. Blood. 2002;99(3):754-8. 
Castriconi R, Cantoni C, Della Chiesa M, Vitale M, Marcenaro E, Conte R, Biassoni R, Bottino C, Moretta L, Moretta A. Transforming growth factor beta 1 inhibits expression of NKp30 and NKG2D receptors: consequences for the NK-mediated killing of dendritic cells. Proc Natl Acad Sci U S A. 2003;100(7):4120-5.

Catalfamo M, Henkart PA. Perforin and the granule exocytosis cytotoxicity pathway. Curr Opin Immunol. 2003;15(5):522-7.

Cerwenka A. New twist on the regulation of NKG2D ligand expression. J Exp Med. 2009;206(2):265-8.

Champsaur M, Lanier LL. Effect of NKG2D ligand expression on host immune responses. Immunol Rev. 2010;235(1):267-85.

Chiesa S, Mingueneau M, Fuseri N, Malissen B, Raulet H, Malissen M, Vivier E, Tomasello E. Multiplicity and plasticity of natural killer cell signaling pathways. Blood. 2006;107(6):2364-72.

Chitadze G, Bhat J, Lettau M, Janssen O, Kabelitz D. Generation of soluble NKG2D ligands: proteolytic cleavage, exosome secretion and functional implications. Scand J Immunol. 2013;78(2):120-9.

Choy MK, Phipps ME. MICA polymorphism: biology and importance in immunity and disease. Trends Mol Med. 2010;16(3):97-106.

Clayton A, Mitchell JP, Court J, Linnane S, Mason MD, Tabi Z. Human tumor-derived exosomes downmodulate NKG2D expression. J Immunol. 2008;180(11):7249-58.

Cooley S, Trachtenberg E, Bergemann TL, Saeteurn K, Klein J, Le CT, Marsh SG, Guethlein LA, Parham $P$, Miller JS, Weisdorf DJ. Donors with group B KIR haplotypes improve relapse-free survival after unrelated hematopoietic cell transplantation for acute myelogenous leukemia. Blood. 2009;113(3):726-32.

Cooper MA, Fehniger TA, Caligiuri MA. The biology of human natural killer-cell subsets. Trends Immunol. 2001;22(11):633-40.

Cosman D, Müllberg J, Sutherland CL, Chin W, Armitage R, Fanslow W, Kubin M, Chalupny NJ. ULBPs, novel MHC class I-related molecules, bind to CMV glycoprotein UL16 and stimulate NK cytotoxicity through the NKG2D receptor. Immunity. 2001;14(2):123-33.

Coudert JD, Zimmer J, Tomasello E, Cebecauer M, Colonna M, Vivier E, Held W. Altered NKG2D function in NK cells induced by chronic exposure to NKG2D ligand-expressing tumor cells. Blood. 2005;106(5):1711-7.

Cullen SP, Martin SJ. Mechanisms of granule-dependent killing. Cell Death Differ. 2008;15(2):251-62.

Degli-Esposti MA, Smyth MJ. Close encounters of different kinds: dendritic cells and NK cells take centre stage. Nat Rev Immunol. 2005;5(2):112-24.

Dickinson AM. Non-HLA genetics and predicting outcome in HSCT. Int J Immunogenet. 2008;35(45):375-80. 
Diefenbach A, Jamieson AM, Liu SD, Shastri N, Raulet DH. Ligands for the murine NKG2D receptor: expression by tumor cells and activation of NK cells and macrophages. Nat Immunol. 2000;1(2):11926.

Diermayr S, Himmelreich H, Durovic B, Mathys-Schneeberger A, Siegler U, Langenkamp U, Hofsteenge J, Gratwohl A, Tichelli A, Paluszewska M, Wiktor-Jedrzejczak W, Kalberer CP, WodnarFilipowicz $A$. NKG2D ligand expression in AML increases in response to HDAC inhibitor valproic acid and contributes to allorecognition by NK-cell lines with single KIR-HLA class I specificities. Blood. 2008;111(3):1428-36.

Dong Z, Cruz-Munoz ME, Zhong MC, Chen R, Latour S, Veillette A. Essential function for SAP family adaptors in the surveillance of hematopoietic cells by natural killer cells. Nat Immunol. 2009;10(9):973-80.

Doubrovina ES, Doubrovin MM, Vider E, Sisson RB, O’Reilly RJ, Dupont B, Vyas YM. Evasion from NK cell immunity by MHC class I chain-related molecules expressing colon adenocarcinoma. J Immunol. 2003;171(12):6891-9.

Douik H, Ben Chaaben A, Attia Romdhane N, Romdhane HB, Mamoghli T, Fortier C, Boukouaci W, Harzallah L, Ghanem A, Gritli S, Makni M, Charron D, Krishnamoorthy R, Guemira F, Tamouza R. Association of MICA-129 polymorphism with nasopharyngeal cancer risk in a Tunisian population. Hum Immunol. 2009;70(1):45-8.

Dressel R, Johnson JP, Günther E. Heterogeneous patterns of constitutive and heat shock induced expression of HLA-linked HSP70-1 and HSP70-2 heat shock genes in human melanoma cell lines. Melanoma Res. 1998;8(6):482-92.

Dressel R, Elsner L, Quentin T, Walter L, Günther E. Heat shock protein 70 is able to prevent heat shock-induced resistance of target cells to CTL. J Immunol. 2000;164(5):2362-71.

Duan X, Deng L, Chen X, Lu Y, Zhang Q, Zhang K, Hu Y, Zeng J, Sun W. Clinical significance of the immunostimulatory MHC class I chain-related molecule $A$ and NKG2D receptor on NK cells in pancreatic cancer. Med Oncol. 2011;28(2):466-74.

Dulphy N, Berrou J, Campillo JA, Bagot M, Bensussan A, Toubert A. NKG2D ligands expression and NKG2D-mediated NK activity in Sezary patients. J Invest Dermatol. 2009;129(2):359-64.

Eckl J, Buchner A, Prinz PU, Riesenberg R, Siegert SI, Kammerer R, Nelson PJ, Noessner E. Transcript signature predicts tissue NK cell content and defines renal cell acrcinoma subgroups independent of TNM staging. J Mol Med (Berl). 2012;90(1):55-66.

El-Gazzar A, Groh V, Spies T. Immunobiology and conflicting roles of the human NKG2D lymphocyte receptor and its ligands in cancer. J Immunol. 2013;191(4):1509-15.

Elsner L, Muppala V, Gehrmann M, Lozano J, Malzahn D, Bickeböller H, Brunner E, Zientkowska M, Hermann T, Walter L, Alves F, Multhoff G, Dressel R. The heat shock protein HSP70 promotes mouse NK cell activity against tumors that express inducible NKG2D ligands. J Immunol. 2007;179(8):552333. 
Elsner L, Flügge PF, Lozano J, Muppala V, Eiz-Vesper B, Demiroglu SY, Malzahn D, Herrmann T, Brunner E, Bickeböller H, Multhoff $G$, Walter L, Dressel R. The endogenous danger signals HSP70 and MICA cooperate in the activation of cytotoxic effector functions of NK cells. J Cell Mol Med. 2010;14(4):992-1002.

Fang M, Lanier LL, Sigal LJ. A role for NKG2D in NK cell-mediated resistance to poxvirus disease. PLoS Pathog. 2008;4(2):e30.

Farag SS, Caligiuri MA. Human natural killer cell development and biology. Blood Rev. 2006;20(3):123-37.

Fehniger TA, Cooper MA, Caligiuri MA. Interleukin-2 and interleukin-15: immunotherapy for cancer. Cytokine Growth Factor Rev. 2002;13(2):169-83.

Ferlazzo G, Münz C. NK cell compartments and their activation by dendritic cells. J Immunol. 2004;172(3):1333-9.

Frigoul A, Lefranc MP. MICA: Standardized IMGT allele nomenclature, polymorphisms and diseases. Recent Res Devel Human Genet. 2005;3:95-145.

Gannage M, Buzyn A, Bogiatzi SI, Lambert M, Soumelis V, Dal Cortivo L, Cavazzana-Calvo M, Brousse $\mathrm{N}$, Caillat-Zucman S. Induction of NKG2D ligands by gamma radiation and tumor necrosis factor-alpha may participate in the tissue damage during acute graft-versus-host disease. Transplantation. 2008;85(6):911-5.

Garrity D, Call ME, Feng J, Wucherpfennig KW. The activating NKG2D receptor assembles in the membrane with two signaling dimers into a hexameric structure. Proc Natl Acad Sci U $S$ A. 2005;102(21):7641-6.

Gasser S, Orsulic S, Brown EJ, Raulet DH. The DNA damage pathway regulates innate immune system ligands of the NKG2D receptor. Nature. 2005;436(7054):1186-90.

Gaudieri S, Longman-Jacobsen N, Tay GK, Dawkins RL. Sequence analysis of the MHC class I region reveals the basis of the genomic matching technique. Hum Immunol. 2001;62(3):279-85.

Giebel S, Locatelli F, Lamparelli T, Velardi A, Davies S, Frumento G, Maccario R, Bonetti F, Wojnar J, Martinetti M, Frassoni F, Giorgiani G, Bacigalupo A, Holowiecki J. Survival advantage with KIR ligand incompatibility in hematopoietic stem cell transplantation from unrelated donors. Blood. 2003;102(3):814-9.

Gilfillan S, Ho EL, Cella M, Yokoyama WM, Colonna M. NKG2D recruits two distinct adapters to trigger NK cell activation and costimulation. Nat Immunol. 2002;3(12):1150-5.

Gilfillan S, Chan CJ, Cella M, Haynes NM, Rapaport AS, Boles KS, Andrews DM, Smyth MJ, Colonna M. DNAM-1 promotes activation of cytotoxic lymphocytes by nonprofessional antigen-presenting cells and tumors. J Exp Med. 2008;205(13):2965-73.

Girardi M, Oppenheim DE, Steele CR, Lewis JM, Glusac E, Filler R, Hobby P, Sutton B, Tigelaar RE, Hayday AC. Regulation of cutaneous malignancy by gammadelta $T$ cells. Science. 2001;294(5542):605-9. 
Giurisato E, Cella M, Takai T, Kurosaki T, Feng Y, Longmore GD, Colonna M, Shaw AS. Phosphatidylinositol 3-kinase activation is required to form the NKG2D immunological synapse. Mol Cell Biol. 2007;27(24):8583-99.

Gonzalez S, Groh V, Spies T. Immunobiology of human NKG2D and its ligands. Curr Top Microbiol Immunol. 2006;298:121-38.

Goto K, Ota M, Ohno S, Mizuki N, Ando H, Katsuyama Y, Maksymowych WP, Kimura M, Bahram S, Inoko H. MICA gene and ankylosing spondylitis: linkage analysis via a transmembrane-encoded triplet repeat polymorphism. Tissue Antigens. 1997;49(5):503-7.

Graham DB, Cella M, Giurisato E, Fujikawa K, Miletic AV, Kloeppel T, Brim K, Takai T, Shaw AS, Colonna M, Swat W. Vav1 controls DAP10-mediated natural cytotoxicity by regulating actin and microtubule dynamics. J Immunol. 2006;177(4):2349-55.

Griffiths GM. Endocytosing the death sentence. J Cell Biol. 2003;160(2):155-6.

Griggs J, Zinkewich-Peotti K. The state of the art: immune-mediated mechanisms of monoclonal antibodies in cancer therapy. Br J Cancer. 2009;101(11):1807-12.

Groh V, Bahram S, Bauer S, Herman A, Beauchamp M, Spies T. Cell stress-regulated human major histocompatibility complex class I gene expressed in gastrointestinal epithelium. Proc Natl Acad Sci U S A. 1996;93(22):12445-50.

Groh V, Rhinehart R, Secrist H, Bauer S, Grabstein KH, Spies T. Broad tumor-associated expression and recognition by tumor-derived gamma delta T cells of MICA and MICB. Proc Natl Acad Sci U S A. 1999;96(12):6879-84.

Groh V, Rhinehart R, Randolph-Habecker J, Topp MS, Riddell SR, Spies T. Costimulation of CD8alphabeta T cells by NKG2D via engagement by MIC induced on virus-infected cells. Nat Immunol. 2001;2(3):255-60.

Groh V, Wu J, Yee C, Spies T. Tumour-derived soluble MIC ligands impair expression of NKG2D and Tcell activation. Nature. 2002;419(6908):734-8.

Groh V, Bruhl A, El-Gabalawy H, Nelson JL, Spies T. Stimulation of T cell autoreactivity by anomalous expression of NKG2D and its MIC ligands in rheumatoid arthritis. Proc Natl Acad Sci U $S$ A. 2003;100(16):9452-7.

Groh V, Smythe K, Dai Z, Spies T. Fas-ligand-mediated paracrine T cell regulation by the receptor NKG2D in tumor immunity. Nat Immunol. 2006;7(7):755-62.

Groth A, Klöss S, von Strandmann EP, Koehl U, Koch J. Mechanisms of tumor and viral immune escape from natural killer cell-mediated surveillance. J Innate Immun. 2011;3(4):344-54.

Gryder BE, Sodji QH, Oyelere AK. Targeted cancer therapy: giving histone deacetylase inhibitors all they need to succeed. Future Med Chem. 2012;4(4):505-24. 
Guerra N, Tan YX, Joncker NT, Choy A, Gallardo F, Xiong N, Knoblaugh S, Cado D, Greenberg NM, Raulet DH. NKG2D-deficient mice are defective in tumor surveillance in models of spontaneous malignancy. Immunity. 2008;28(4):571-80.

Hamala N, Braun M, Kahlert C, Spille A, Quack C, Rahbari N, Koch M, Weitz J, Kloor M, Zoernig I, Schirmacher P, Brand K, Grabe N, Falk CS. Natural killer cells are scarce in colorectal carcinoma tissue despite high levels of chemokines and cytokines. Clin Cancer Res. 2011;17(4):678-89.

Herberman RB, Nunn ME, Lavrin DH. Natural cytotoxic reactivity of mouse lymphoid cells against syngeneic acid allogeneic tumors. I. Distribution of reactivity and specificity. Int I Cancer. 1975;16(2):216-29.

Heusel JW, Wesselschmidt RL, Shresta S, Russell JH, Ley TJ. Cytotoxic lymphocytes require granzyme $B$ for the rapid induction of DANN fragmentation and apoptosis in allogeneic target cells. Cell. 1994;76(6):977-87.

Hilpert J, Grosse-Hovest L, Grünebach F, Buechele C, Nuebling T, Raum T, Steinle A, Salih HR. Comprehensive analysis of NKG2D ligand expression and release in leukemia: implications for NKG2D-mediated NK cell responses. J Immunol. 2012;189(3):1360-71.

Horng T, Bezbradica JS, Medzhitov R. NKG2D signaling is coupled to the interleukin 15 receptor signaling pathway. Nat Immunol. 2007;8(12):1345-52.

Houchins JP, Yabe T, McSherry C, Bach FH. DNA sequence analysis of NKG2, a family of related cDNA clones encoding type II integral membrane proteins on human natural killer cells. 1991;173(4):101720.

Huenecke S, Zimmermann SY, Kloess S, Esser R, Brinkmann A, Tramsen L, Koenig M, Erben S, Seidl C, Tonn T, Eggert A, Schramm A, Bader P, Klingebiel T, Lehrnbecher T, Passweg JR, Sorensen J, Schwabe $D$, Koehl U. IL-2-driven regulation of NK cell receptors with regard to the distribution of CD16+ and CD16- subpopulations and in vivo influence after haploidentical NK cell infusion. J Immunother. 2010;33(2):200-10.

Imai K, Matsuyama S, Miyake S, Suga K, Nakachi K. Natural cytotoxic activity of peripheral-blood lymphocytes and cancer incidence: an 11-year follow-up study of a general population. Lancet. 2000;356(9244):1795-9.

Irtegun S, Wood RJ, Ormsby AR, Mulhern TD, Hatters DM. Tyrosine 416 is phosphorylated in the closed, repressed conformation of c-Src. PLoS One. 2013;8(7):e71035.

Jamieson AM, Diefenbach A, McMahon CW, Xiong N, Carlyle JR, Raulet DH. The role of the NKG2D imminoreceptor in immune cell activation and natural killing. Immunity. 2002;17(1):19-29.

Jiang X, Zou Y, Huo Z, Yu P. Association of major histocompatibility complex class I chain-related gene A microsatellite polymorphism and hepatocellular carcinoma in South China Han population. Tissue Antigens. 2011;78(2):143-7.

Jinushi M, Takehara T, Tatsumi T, Kanto T, Groh V, Spies T, Kimura R, Miyagi T, Mochizuki K, Sasaki Y, Hayashi N. Expression and role of MICA and MICB in human hepatocellular carcinomas and their regulation by retinoic acid. Int J Cancer. 2003;104(3):354-61. 
Jinushi M, Hodi FS, Dranoff G. Therapy-induced antibodies to MHC class I chain-related protein A antagonize immune suppression and stimulate antitumor cytotoxicity. Proc Natl Acad Sci U S A. 2006;103(24):9190-5.

Jumnainsong $A$, Romphruk AV, Jearanaikoon $P$, Klumkrathok $K$, Romphruk $A$, Luanrattanakorn $S$, Leelayuwat C. Association of polymorphic extracellular domains of MICA with cervical cancer in northeastern Thai population. Tissue Antigens. 2007;69(4):326-33.

Kaiser BK, Yim D, Chow IT, Gonzalez S, Dai Z, Mann HH, Strong RK, Groh V, Spies T. Disulphideisomerase-enabled shedding of tumour-associated NKG2D ligands. Nature. 2007;447(7143):482-6.

Kärre K. Role of target histocompatibility antigens in regulation of natural killer activity: a reevaluation and a hypothesis. In Mechanisms of Cytotoxicity by NK Cells. Herberman RB, Callewaert DM, editors. Academic Press, Orlando, FL. 1985:81-92.

Kärre K, Ljunggren HG, Piontek G, Kiessling R. Selective rejection of H-2-deficient lymphoma variants suggests alternative immune defence strategy. Nature. 1986;319(6055):675-8.

Kato N, Tanaka J, Sugita J, Toubai T, Miura Y, Ibata M, Syono Y, Ota S, Kondo T, Asaka M, Imamura M. Regulation of the expression of MHC class I-related chain A, B (MICA, MICB) via chromatin remodeling and its impact on the susceptibility of leukemic cells to the cytotoxicity of NKG2Dexpressing cells. Leukemia. 2007;21(10):2103-8.

Kiessling R, Klein E, Wigzell H. "Natural" killer cells in the mouse. I. Cytotoxic cells with specificity for mouse Moloney leukemia cells. Specificity and distribution according to genotype. Eur J Immunol. 1975;5(2):112-7.

Kim HS, Das A, Gross CC, Bryceson YT, Long EO. Synergistic signals for natural cytotoxicity are required to overcome inhibition by c-Cbl ubiquitin ligase. Immunity. 2010;32(2):175-86.

Kirsten H, Petit-Teixeira E, Scholz M, Hasenclever D, Hantmann H, Heider D, Wagner U, Sack U, Hugo Teixeira V, Prum B, Burkhardt J, Pierlot C, Emmrich F, Cornelis F, Ahnert P. Association of MICA with rheumatoid arthritis independent of known HLA-DRB1 risk alleles in a family-based and a case control study. Arthritis Res Ther. 2009;11(3):R60.

Kitcharoen K, Witt CS, Romphruk AV, Christiansen FT, Leelayuwat C. MICA, MICB, and MHC beta block matching in bone marrow transplantation: relevance to transplantation outcome. Hum Immunol. 2006;67(3):238-46.

Kloess S, Huenecke S, Piechulek D, Esser R, Koch J, Brehm C, Soerensen J, Gardlowski T, Brinkmann A, Bader P, Passweg J, Klingebiel T, Schwabe D, KoehI U. IL-2-activated haploidentical NK cells restore NKG2D-mediated NK-cell cytotoxicity in neuroblastoma patients by scavenging of plasma MICA. Eur J Immunol. 2010;40(11):3255-67.

Koch J, Steinle A, Watzl C, Mandelboim O. Activating natural cytotoxicity receptors of natural killer cells in cancer and infection. Trends Immunol. 2013;34(4):182-91.

Krockenberger M, Dombrowski Y, Weidler C, Ossadnik M, Hönig A, Häusler S, Voigt H, Becker JC, Leng L, Steinle A, Weller M, Bucala R, Dietl J, Wischhusen J. Macrophage migration inhibitory factor 
contributes to the immune escape of ovarian cancer by down-regulating NKG2D. J Immunol. 2008;180(11):7338-48.

Kröger N, Shaw B, lacobelli S, Zabelina T, Peggs K, Shimoni A, Nagler A, Binder T, Eiermann T, Madrigal A, Schwerdtfeger R, Kiehl M, Sayer HG, Beyer J, Bornhäuser M, Ayuk F, Zander AR, Marks DI; Clinical Trial Committee of the British Society of Blood and Marrow Transplantation and the German Cooperative Transplant Group. Br J Haemotol. 2005;129(5):631-43.

Kubin M, Cassiano L, Chalupny J, Chin W, Cosman D, Fanslow W, Müllberg J, Rousseau AM, Ulrich D, Armitage R. ULBP1, 2, 3: novel MHC class I-related molecules that bind to human cytomegalovirus glycoprotein UL16, activate NK cells. Eur J Immunol. 2001;31(5):1428-37.

Kumanovics A, Takada T, Lindahl KF. Genomic organization of the mammalian MHC. Annu Rev Immunol. 2003;21:629-57.

Lanier LL. Up on the tightrope: natural killer cell activation and inhibition. Nat Immunol. 2008;9(5):495-502.

Lanier LL. DAP10- and DAP12-associated receptors in innate immunity. Immunol Rev. 2009;227(1):150-60.

Lavado-Velenzuela R, Benavides M, Carabantes F, Alonso A, Caballero A. MHC class I chain-related gene A transmembrane polymorphism in Spanish women with breast cancer. Tissue Antigens. 2009;74(1):46-9.

Lee JC, Lee KM, Kim DW, Heo DS. Elevated TGF-beta1 secretion and down-modulation of NKG2D underlies impaired NK cytotoxicity in cancer patients. J Immunol. 2004;172(12):7335-40.

Leelayuwat C, Townend DC, Degli-Esposti MA, Abraham LJ, Dawkins RL. A new polymorphic and multicopy MHC gene family related to nonmammalian class I. Immunogenetics. 1994;40(5):339-51.

Leung W. Use of NK cell activity in cure by transplant. Br J Haematol. 2011;155(1):14-29.

Li P, Willie ST, Bauer S, Morris DL, Spies T, Strong RK. Crystal structure of the MHC class I homolog MIC-A, a gammadelta T cell ligand. Immunity. 1999;10(5):577-84.

Li P, Morris DL, Willcox BE, Steinle A, Spies T, Strong RK. Complex structure of the activating immunoreceptor NKG2D and its MHC class I-like ligand MICA. Nat Immunol. 2001;2(5):443-51.

Li K, Mandai M, Hamanishi J, Matsumura N, Suzuki A, Yagi H, Yamaguchi K, Baba T, Fujii S, Konishi I. Clinical significance of the NKG2D ligands, MICA/B and ULBP2 in ovarian cancer: high expression of ULBP2 is an indicator of poor prognosis. Cancer Immunol Immunother. 2009;58(5):641-52.

Livak KJ, Schmittgen TD. Analysis of relative gene expression data using real-time quantitative PCR and the 2(-delta delta c(t)) method. Methods. 2001;25(4):402-8.

Ljunggren HG, Kärre K. In serach of the'missing self': MHC molecules and NK cell recognition. Immunol Today. 1990;11(7):237-44. 
Locatelli F, Merli P, Rutella S. At the bedside: innate immunity as an immunotherapy tool for hematological malignancies. J Leukoc Biol. 2013;94(6):1141-57.

Long EO. Ready for prime time: Nk cell priming by dendritic cells. Immunity. 2007;26(4):385-7.

Long EO, Sik Kim H, Liu D, Peterson ME, Rajagopalan S. Controlling natural killer cell responses: integration of signals for activation and inhibition. Annu Rev Immunol. 2013;31:227-58.

Lopez-Hernandez R, Valdes M, Lucas D, Campillo JA, Martinez-Garcia P, Salama H, Lopez M, Salgado G, Botella C, Minguela A, Miras M, Alvarez-Lopez MR, Carballo F, Muro M. Association analysis of MICA gene polymorphism and MICA-129 dimorphism with inflammatory bowel disease susceptibility in a Spanish population. Hum Immunol. 2010;71(5):512-4.

Lucas $M$, Schachterle W, Oberle K, Aichele P, Diefenbach A. Dendritic cells prime natural killer cells by trans-presenting interleukin 15. Immunity. 2007;26(4):503-17.

Luo QZ, Lin L, Gong Z, Mei B, Xu YJ, Huo Z, Yu P. Positive association of major histocompatibility complex class I chain-related gene A polymorphism with leukemia susceptibility in the people of Han nationality of Southern China. Tissue Antigens. 2011;78(3):178-84.

Martinez-Borra J, Gonzalez S, Lopez-Vazquez A, Gelaz MA, Armas JB, Kanga U, Mehra NK, LopezLarrea C. HLA-B27 alone rather than B27-related class I haplotypes contributes to ankylosing spondylitis susceptibility. Hum Immunol. 2000;61(2):131-9.

Meresse B, Chen Z, Ciszewski C, Tretiakova M, Bhagat G, Krausz TN, Raulet DH, Lanier LL, Groh V, Spies T, Ebert EC, Green PH, Jabri B. Coordinated induction by IL15 of a TCR-independent NKG2D signaling pathway converts CTL into lymphokine-activated killer cells in celiac disease. Immunity. 2004;21(3):357-66.

Miller JS, Soignier Y, Panoskaltsis-Mortari A, McNearney SA, Yun GH, Fautsch SK, McKenna D, Le C, Defor TE, Burns LJ, Orchard PJ, Blazar BR, Wagner JE, Slungaard A, Weisdorf DJ, Okazaki IJ, McGlave PB. Successful adoptive transfer and in vivo expansion of human haploidentical NK cells in patients with cancer. Blood. 2005;105(8):3051-7.

Mizuki N, Ota M, Kimura M, Ohno S, Ando H, Katsuyama Y, Yamazaki M, Watanabe K, Goto K, Nakamura S, Bahram S, Inoko $\mathrm{H}$. Triplet repeat polymorphism in the transmembrane region of the MICA gene: a strong association of six GCT repetitions with Behcet disease. Proc Natl Acad Sci U S A. 1997;94(4):1298-1303.

Mizuki N, Meguro A, Tohnai I, Gül A, Ohno S, Mizuki N. Association of major histocompatibility complex class I chain-related gene A and HLA-B alleles with Behcet's disease in Turkey. Jpn J Ophthalmol. 2007;51(6):431-6.

Moretta A, Bottino C, Vitale M, Pende D, Cantoni C, Mingari MC, Biassoni R, Moretta L. Activating receptors and coreceptors involved in human natural killer cell-mediated cytolysis. Annu Rev Immunol. 2001;19:197-223.

Moretta A, Pende D, Locatelli F, Moretta L. Activating and inhibitory killer immunoglobulin-like receptors (KIR) in haploidentical haemopoietic stem cell transplantation to cure high-risk leukaemias. Clin Exp Immunol. 2009;157(3):325-31. 
Morishima Y, Sasazuki T, Inoko H, Juji T, Akaza T, Yamamoto K, Ishikawa Y, Kato S, Sao H, Sakamaki H, Kawa K, Hamajima N, Asano S, Kodera Y. The clinical significance of human leukocyte antigen (HLA) allele compatibility in patients receiving a marrow transplant from serologically HLA-A, HLA-B, and HLA-DR matched unrelated donors. Blood. 2002;99(11):4200-6.

Nausch N, Cerwenka A. NKG2D ligands in tumor immunity. Oncogene. 2008;27(45):5944-58.

Ni J, Miller M, Stojanovic A, Garbi N, Cerwenka A. Sustained effector function of IL-12/15/18preactivated NK cells against established tumors. J Exp Med. 2012;209(13):2351-65.

Nice TJ, Coscoy L, Raulet DH. Posttranslational regulation of the NKG2D ligand Mult1 in response to cell stress. J Exp Med. 2009;206(2):287-98.

Nicholson DW. Caspase structure, proteolytic substrates, and function during apoptotic cell death. Cell Death Differ. 1999;6(11):1028-42.

Nitahara A, Shimura H, Ito A, Tomiyama K, Ito M, Kawai K. NKG2D ligation without T cell receptor engagement triggers both cytotoxicity and cytokine production in dendritic epidermal $\mathrm{T}$ cells. $J$ Invest Dermatol. 2006;126(5):1052-8.

Nomura M, Zou Z, Joh T, Takihara Y, Matsuda Y, Shimada K. Genomic structures and characterization of Rae1 family members encoding GPI-anchored cell surface proteins and expressed predominantly in embryonic mouse brain. J Biochem. 1996;120(5):987-95.

Novota P, Zinöcker S, Norden J, Wang XN, Sviland L, Opitz L, Salinas-Riester G, Rolstad B, Dickinson AM, Walter L, Dressel R. Expression profiling of major histocompatibility and natural killer complex genes reveals candidates for controlling risk of graft versus host disease. PLoS One. 2011;6(1):e16582.

Nückel H, Switala M, Sellmann L, Horn PA, Dürig J, Dührsen U, Küppers R, Grosse-Wilde H, Rebmann V. The prognostic significance of soluble NKG2D ligands in B-cell chronic lymphocytic leukemia. Leukemia. 2010;24(6):1152-9.

Olcese L, Lang P, Vely F, Cambiaggi A, Marguet D, Blery M, Hippen KL, Biassoni R, Moretta A, Moretta L, Cambier JC, Vivier E. Human and mouse killer-cell inhibitory receptors recruit PTP1C and PTP1D protein tyrosine phosphatases. J Immunol. 1996;156(12):4531-4.

Oldham RK, Herberman RB. Evaluation of cell-mediated cytotoxic reactivity against tumor associated antigens with 125I-iododeoxyuridine labeled target cells. J Immunol. 1973;111(6):862-71.

Onda H, Ohkibo S, Shintani Y, Ogi K, Kikuchi K, Tanaka H, Yamamoto K, Tsuji I, Ishibashi Y, Yamada T, Kitada C, Suzuki N, Sawada H, Nishimura O, Fujino M. A novel secreted tumor antigen with glycosylphosphatidylinositol-anchored structure ubiquitously expressed in human cancers. Biochem Biophys Res Commun. 2001;285(2):235-43.

Oppenheim DE, Roberts SJ, Clarke SL, Filler R, Lewis JM, Tigelaar RE, Girardi M, Hayday AC. Sustained localized expression of ligand for the activating NKG2D receptor impairs natural cytotoxicity in vivo and reduces tumor immunosurveillance. Nat Immunol. 2005;6(9):928-37. 
Orange JS, Ballas ZK. Natural killer cells in human health and disease. Clin Immunol. 2006;118(1):1-10.

Palmer JM, Rajasekaran K, Thakar MS, Malarkannan S. Clinical relevance of natural killer cells following hematopoietic stem cell transplantation. J Cancer. 2013;4(1):25-35.

Parmar S, Del Lima M, Zou Y, Patah PA, Liu P, Cano P, Rondon G, Pesoa S, de Padua Silva L, Qazilbash MH, Hosing C, Popat U, Kebriaei P, Shpall EJ, Giralt S, Champlin RE, Stastny P, Fernandez-Vina M. Donor-recipient mismatches in $\mathrm{MHC}$ class I chain-related gene $\mathrm{A}$ in unrelated donor transplantation lead to increased incidence of acute graft-versus-host disease. Blood. 2009;114(14):2884-7.

Paschen A, Sucker A, Hill B, Moll I, Zapatka M, Nguyen XD, Sim GC, Gutmann I, Hassel J, Becker JC, Steinle A, Schadendorf D, Ugurel S. Differential clinical significance of individual NKG2D ligands in melanoma: soluble ULBP2 as an indicator of poor prognosis superior to S100B. Clin Cancer Res. 2009;15(16):5208-15.

Petersdorf EW, Gooley TA, Anasetti C, Martin PJ, Smith AG, Mickelson EM, Woolfrey AE, Hansen JA. Optimizing outcome after unrelated marrow transplantation by comprehensive matching of HLA class I and II alleles in the donor and recipient. Blood. 1998;92(10):3515-20.

Platonova S, Cherfils-Vicini J, Damotte D, Crozet L, Vieillard V, Validire P, Andre P, Dieu-Nosjean MC, Alifano M, Regnard JF, Fridman WH, Sautes-Fridman C, Cremer I. Profound coordinated alterations of intratumoral NK cell phenotype and function in lung carcinoma. Cancer Res. 2011;71(16):5412-22.

Pollock RA, Chandran V, Pellett FJ, Thavaneswaran A, Eder L, Barrett J, Rahman P, Farewell V, Gladman DD. The functional MICA-129 polymorphism is associated with skin but not joint manifestations of psoriatic disease independently of HLA-B and HLA-C. Tissue Antigens. 2013;82(1):43-7.

Raache R, Belanteur K, Amroun H, Benyahia A, Heniche A, Azzouz M, Mimouni S, Gervais T, Latinne D, Boudiba A, Attal N, Abbadi MC. Association of major histocompatibility complex class 1 chain-related gene a dimorphism with type 1 diabetes and latent autoimmune diabetes in adults in the Algerian population. Clin Vaccine Immunol. 2012;19(4):557-61.

Radaev S, Sun PD. Structure and function of natural killer cell surface receptors. Annu Rev Biophys Biomol Struct. 2003;32:93-114.

Radosavljevic M, Cuillerier B, Wilson MJ, Clement O, Wicker S, Gilfillan S, Beck S, Trowsdale J, Bahram S. A cluster of ten novel MHC class I related genes on human chromosome 6q24.2-q25.3. Genomics. 2002;79(1):114-23.

Raulet DH. Roles of the NKG2D immunoreceptor and its ligands. Nat Rev Immunol. 2003;3(10):78190.

Raulet DH, Guerra N. Oncogenic stress sensed by the immune system: role of natural killer cell receptors. Nat Rev Immunol. 2009;9(8):568-80.

Raulet DH, Gasser S, Gowen BG, Deng W, Jung H. Regulation of ligands for the NKG2D activating receptor. Annu Rev Immunol. 2013;31:413-41. 
Rebmann V, Schütt P, Brandhorst D, Opalka B, Moritz T, Nowrousian MR, Grosse-Wilde H. Soluble MICA as an independent prognostic factor for the overall survival and progression-free survival of multiple myeloma patients. Clin Immunol. 2007;123(1):114-20.

Reiners KS, Kessler J, Sauer M, Rothe A, Hansen HP, Reusch U, Hucke C, Köhl U, Dürkop H, Engert A, von Strandmann EP. Rescue of impaired NK cell activity in hodgkin lymphoma with bispecific antibodies in vitro and in patients. Mol Ther. 2013;21(4):895-903.

Rincon-Orozco B, Kunzmann V, Wrobel P, Kabelitz D, Steinle A, Herrmann T. Activation of V gamma 9 V delta 2 T cells by NKG2D. J Immunol. 2005;175(4):2144-51.

Roberts Al, Lee L, Schwarz E, Groh V, Spies T, Ebert EC, Jabri B. NKG2D receptors induced by IL-15 costimulate CD28-negative effector CTL in the tissue microenvironment. J Immunol. 2001;167(10):5527-30.

Roda-Navarro P, Reyburn HT. The traffic of the NKG2D/DAP10 receptor complex during natural killer (NK) cell activation. J Biol Chem. 2009;284(24):16463-72.

Romagne F, Andre P, Spee P, Zahn S, Anfossi N, Gauthier L, Capanni M, Ruggeri L, Benson DM Jr, Blaser BW, Della Chiesa M, Moretta A, Vivier E, Caligiuri MA, Velardi A, Wagtmann N. Preclinical characterization of 1-7F9, a novel human anti-KIR receptor therapeutic antibody that augments natural killer-mediated killing of tumor cells. Blood. 2009;114(13):2667-77.

Romagne F, Vivier E. Natural killer cell-based therapies. F1000 Med Rep. 2011;3:9.

Routes JM, Ryan S, Morris K, Takaki R, Cerwenka A, Lanier LL. Adenovirus serotype 5 E1A sensitizes tumor cells to NKG2D-dependent NK cell lysis and tumor rejection. J Exp Med. 2005;202(11):1477-82.

Ruggeri L, Capanni M, Urbani E, Perruccio K, Shlomchik WD, Tosti A, Posati S, Rogaia D, Frassoni F, Aversa F, Martelli MF, Velardi A. Effectiveness of donor natural killer cell alloreactivity in mismatched hematopoietic transplants. Science. 2002;295(5562):2097-100.

Ruggeri L, Mancusi A, Capanni M, Urbani E, Carotti A, Aloisi T, Stern M, Pende D, Perruccio K, Burchielli E, Topini F, Bianchi E, Aversa F, Martelli MF, Velardi A. Donor natural killer cell allorecognition of missing self in haploidentical hematopoietic transplantation for acute myeloid leukemia: challenging its predictive value. Blood. 2007;110(1):433-40.

Salih HR, Rammensee HG, Steinle A. Cutting edge: down-regulation of MICA on human tumors by proteolytic shedding. J Immunol. 2002;169(8):4098-102.

Salih HR, Antropius H, Gieseke F, Lutz SZ, Kanz L, Rammensee HG, Steinle A. Functional expression and release of ligands for the activating immunoreceptor NKG2D in leukemia. Blood. 2003;102(4):1389-96.

Salvarani C, Boiardi L, Mantovani V, Olivieri I, Ciancio G, Cantini F, Salvi F, Malatesta R, Molinotti C, Govoni M, Trotta F, Filippini D, Paolazzi G, Viggiani M. J Rheumatol. 2001;28(8):1867-70.

Sanchez-Correa B, Morgado S, Gayoso I, Bergua JM, Casado JG, Arcos MJ, Bengochea ML, Duran E, Solana R, Tarazona R. Human NK cells in acute myeloid leukaemia patients: analysis of NK cellactivating receptors and their ligands. Cancer Immunol Immunother. 2011;60(8):1195-205. 
Sasazuki T, Juji T, Morishima Y, Kinukawa N, Kashiwabara H, Inoko H, Yoshida T, Kimura A, Akaza T, Kamikawaji N, Kodera Y, Takaku F. Effect of matching of class I HLA alleles on clinical outcome after transplantation of hematopoietic stem cells from an unrelated donor. Japan marrow donor program. N Engl J Med. 1998;339(17):1177-85.

Schrambach S, Ardizzone M, Leymarie V, Sibilia J, Bahram S. In vivo expression pattern of MICA and MICB and its relevance to auto-immunity and cancer. PLoS One. 2007;2(6):e518.

Sconocchia G, Lau M, Provenzano M, Rezvani K, Wongsena W, Fujiwara H, Hensel N, Melenhorst J, Li J, Ferrone S, Barrett AJ. The antileukemia effect of HLA-matched NK and NK-T cells in chronic myelogenous leukemia involves NKG2D-target-cell interactions. Blood. 2005;106(10):3666-72.

Screpanti V, Wallin RP, Ljunggren HG, Grandien A. A central role for death receptor-mediated apoptosis in the rejection of tumors by NK cells. J Immunol. 2001;167(4):2068-73.

Screpanti V, Wallin RP, Grandien A, Ljunggren HG. Impact of FASL-induced apoptosis in the elimination of tumor cells by NK cells. Mol Immunol. 2005;42(4):495-9.

Segovis CM, Schoon RA, Dick CJ, Nacusi LP, Leibson PJ, Billadeau DD. PI3K links NKG2D signaling to a CrkL pathway involved in natural killer cell adhesion, polarity, and granule secretion. J Immunol. 2009;182(11):6933-42.

Shiina T, Tamiya G, Oka A, Takishima N, Yamagata T, Kikkawa E, Iwata K, Tomizawa M, Okuaki N, Kuwano Y, Watanabe K, Fukuzumi Y, Itakura S, Sugawara C, Ono A, Yamazaki M, Tashiro H, Ando A, Ikemura T, Soeda E, Kimura M, Bahram S, Inoko H. Molecular dynamics of MHC genesis unraveled by sequence analysis of the 1,796,938-bp HLA class I region. Proc Natl Acad Sci U $S$ A. 1999;96(23):13282-7.

Shresta S, PPham CT, Thomas DA, Graubert TA, Ley TJ. How do cytotoxic lymphocytes kill their targets? Curr Opin Immunol. 1998;10(5):581-7.

Smyth MJ, Hayakawa Y, Takeda K, Yagita H. New aspects of natural-killer-cell surveillance and therapy of cancer. Nat Rev Cancer. 2002;2(11):850-61.

Smyth MJ, Swann J, Cretney E, Zerafa N, Yokoyama WM, Hayakawa Y. NKG2D function protects the host from tumor initiation. J Exp Med. 2005;202(5):583-8.

Steinle A, Li P, Morris DL, Groh V, Lanier LL, Strong RK, Spies T. Interactions of human NKG2D with its ligands MICA, MICB, and homolgs of the mouse RAE-1 protein family. Immunogenetics. 2001;53(4):279-87.

Stern-Ginossar N, Gur C, Biton M, Horwitz E, Elboim M, Stanietsky N, Mandelboim M, Mandelboim O. Human microRNAs regulate stress-induced immune responses mediated by the receptor NKG2D. Nat Immunol. 2008;9(9):1065-73.

Strong RK, McFarland BJ. NKG2D and related immunoreceptors. Adv Protein Chem. 2004;68:281-312. 
Sutherland CL, Chalupny NJ, Schooley K, VandenBos T, Kubin M, Cosman D. UL16-binding proteins, novel MHC class I-related proteins, bind to NKG2D and activate multiple signaling pathways in primary NK cells. J Immunol. 2002;168(2):671-9.

Tamaki S, Sanefuzi N, Ohgi K, Imai Y, Kawakami M, Yamamoto K, Ishitani A, Hatake K, Kirita T. An association between the MICA-A5.1 allele and an increased susceptibility to oral squamous cell carcinoma in Japanese patients. J Oral Pathol Med. 2007;36(6):351-6.

Tamaki S, Kawakami M, Yamanaka Y, Shimomura H, Imai Y, Ishida J, Yamamoto K, Ishitani A, Hatake $\mathrm{K}$, Kirita T. Relationship between soluble MICA and the MICA A5.1 homozygous genotype in patients with oral squamous cell carcinoma. Clin Immunol. 2009;130(3):331-7.

Tay GK, Witt CS, Christiansen FT, Charron D, Baker D, Herrmann R, Smith LK, Diepeveen D, Mallal S, McCluskey J, et al. Matching for MHC haplotypes results in improved survival following unrelated bone marrow transplantation. Bone Marrow Transplant. 1995;15(3):381-5.

Terme M, Ullrich E, Delahaye NF, Chaput N, Zitvogel L. Natural killer cell-directed therapies: moving from unexpected results to successful strategies. Nat Immunol. 2008;9(5):486-94.

Thomas M, Wills M, Lehner PJ. Natural killer cell evasion by an E3 ubiquitin ligase from Kaposi's sarcoma-associated herpesvirus. Biochem Soc Trans. 2008;36(Pt 3):459-63.

Tian W, Zeng XM, Li LX, Jin HK, Luo QZ, Wang F, Guo SS, Cao Y. Gender-specific associations between MICA-STR and nasopharyngeal carcinoma in a southern Chinese Han population. Immunogenetics. 2006;58(2-3):113-21.

Titus JA, Perez P, Kaubisch A, Garrido MA, Segal DM. Human K/natural killer cells targeted with hetero-cross-linked antibodies specifically lyse tumor cells in vitro and prevent tumor growth in vivo. J Immunol. 1987;139(9):3153-8.

Trinchieri G. Biology of natural killer cells. Adv Immunol. 1989;47:187-376.

Trinchieri G and Gerosa F. Immunoregulation by interleukin-12. J Leukoc Biol. 1996;59(4):505-11.

Upshaw JL, Arneson LN, Schoon RA, Dick CJ, Billadeau DD, Leibson PJ. NKG2D-mediated signaling requires a DAP10-bound Grb2-Vav1 intermediate and phosphatidylinositol-3-kinase in human natural killer cells. Nat Immunol. 2006;7(5):524-32.

Veeramani S, Wang SY, Dahle C, Blackwell S, Jacobus L, Knutson T, Button A, Link BK, Weiner GJ. Rituximab infusion induces NK activation in lymphoma patients with the high-avidity CD16 polymorphism. Blood. 2011;118(12):3347-9.

Venkataraman GM, Suciu D, Groh V, Boss JM, Spies T. Promoter region architecture and transcriptional regulation of the genes for the MHC class I-related chain A and B ligands of NKG2D. $J$ Immunol. 2007;178(2):961-9.

Venstrom JM, Gooley TA, Spellman S, Pring J, Malkki M, Dupont B, Petersdorf E, Hsu KC. Donor activating KIR3DS1 is associated with decreased acute GVHD in unrelated allogeneic hematopoietic stem cell transplantation. Blood. 2010;115(15):3162-5. 
Vesely MD, Kershaw MH, Schreiber RD, Smyth MJ. Natural innate and adaptive immunity to cancer. Annu Rev Immunol. 2011;29:235-71

Vey N, Bourhis J, Dombret H, Bordessoule D, Prebet T, Charbonnier A, Squiban P, Damholt B, Blaise D, Olive D. A phase I study of the anti-natural killer inhibitory receptor (KIR) monoclonal antibody (17F9, IPH2101) in elderly patients with acute myeloid leukemia (AML). J Clin Oncol. 2009;27(15S):3015.

Vivier E, Nunes JA, Vely F. Natural killer cell signaling pathways. Science. 2004;306(5701):1517-9.

Vivier E, Raulet DH, Moretta A, Caligiuri MA, Zitvogel L, Lanier LL, Yokoyama WM, Ugolini S. Innate or adaptive immunity? The example of natural killer cells. Science. 2011;331(6013):44-9.

Vivier E, Ugolini S, Blaise D, Chabannon C, Brossay L. Targeting natural killer cells and natural killer T cells in cancer. Nat Rev Immunol. 2012;12(4):239-52.

von Strandmann EP, Hansen HP, Reiners KS, Schnell R, Borchmann P, Merkert S, Simhadri VR, Draube A, Reiser M, Purr I, Hallek M, Engert A. A novel bispecific protein (ULBP2-BB4) targeting the NKG2D receptor on natural killer (NK) cells and CD138 activates NK cells and has potent antitumor activity against human multiple myeloma in vitro and in vivo. Blood. 2006;107(5):1955-62.

Voskoboinik I, Smyth MJ, Trapani JA. Perforin-mediated target-cell death and immune homeostasis. Nat Rev Immunol. 2006;6(12):940-52.

Waldhauer I, Goehlsdorf D, Gieseke F, Weinschenk T, Wittenbrink M, Ludwig A, Stevanovic S, Rammensee HG, Steinle A. Tumor-associated MICA is shed by ADAM proteases. Cancer Res. 2008;68(15):6368-76.

Wallace GR, Verity DH, Delamaine LJ, Ohno S, Inoko H, Ota M, Mizuki N, Yabuki K, Kondiatis E, Stephens HA, Madanat W, Kanawati CA, Stanford MR, Vaughan RW. MIC-A allele profiles and HLA class I associations in Behcet's disease. Immunogenetics. 1999;49(7-8):613-7.

Walzer T, Dalod M, Robbins SH, Zitvogel L, Vivier E. Natural-killer cells and dendritic cells: "I'union fait la force". Blood. 2005;106(7):2252-8.

Warren EH, Zhang XC, Li S, Fan W, Storer BE, Chien JW, Boeckh MJ, Zhao LP, Martin PJ, Hansen JA. Effect of MHC and non-MHC donor/recipient genetic disparity on the outcome of allogeneic HCT. Blood. 2012;120(14):2796-806.

Wesselkamper SC, Eppert BL, Motz GT, Lau GW, Hassett DJ, Borchers MT. NKG2D is critical for NK cell activation in host defense against Pseudomonas aeruginosa respiratory infection. J Immunol. 2008;181(8):5481-9.

Westermann J, Pabst R. Distribution of lymphocyte subsets and natural killer cells in the human body. Clin Investig. 1992;70(7):539-44.

Whang MI, Guerra N, Raulet DH. Costimulation of dendritic epidermal gammadelta T cells by a new NKG2D ligand expressed specifically in the skin. J Immunol. 2009;182(8):4557-64. 
Wiemann K, Mittrücker HW, Feger U, Welte SA, Yokoyama WM, Spies T, Rammensee HG, Steinle A. Systemic NKG2D down-regulation impairs NK and CD8 T cell responses in vivo. J Immunol. 2005;175(2):720-9.

Wrobel P, Shojaei H, Schittek B, Gieseler F, Wollenberg B, Kalthoff H, Kabelitz D, Wesch D. Lysis of a broad range of epithelial tumour cells by human gamma delta T cells: involvement of NKG2D ligands and T-cell receptor- versus NKG2D-dependent recognition. Scand J Immunol. 2007; 66(2-3):320-8.

Wu J, Song $\mathrm{Y}$, Bakker $\mathrm{AB}$, Bauer S, Spies T, Lanier LL, Phillips JH. An activating immunoreceptor complex formed by NKG2D and DAP10. Science. 1999;285(5428):730-2.

Wu JD, Higgins LM, Steinle A, Cosman D, Haugk K, Plymate SR. Prevalent expression of the immunostimulatory $\mathrm{MHC}$ class I chain-related molecule is counteracted by shedding in prostate cancer. J Clin Invest. 2004;114(4):560-8.

Yoshida K, Komai K, Shiozawa K, Mashida A, Horiuchi T, Tanaka Y, Nose M, Hashiramoto A, Shiozawa S. Role of the MICA polymorphism in systemic lupus erythematosus. Arthritis Rheum. 2011;63(10):3058-66.

Zhao J, Jiang Y, Lei Y, Zou K, Wang C, Huang S, Yi F, Xia B. Functional MICA-129 polymorphism and serum levels of soluble MICA are correlated with ulcerative colitis in Chinese patients. $J$ Gastroenterol Hepatol. 2011;26(3):593-8.

Zompi S, Hamerman JA, Ogasawara K, Schweighoffer E, Tybulewics VL, Di Santo JP, Lanier LL, Colucci F. NKG2D triggers cytotoxicity in mouse NK cells lacking DAP12 or Syk family kinases. Nat Immunol. 2003;4(6):565-72.

Zou Y, Mirbaha F, Lazaro A, Zhang Y, Lavingia B, Stastny P. MICA is a target for complementdependent cytotoxicity with mouse monoclonal antibodies and human alloantibodies. Hum Immunol. 2002;63(1):30-9.

Zou $\mathrm{Y}$, Stastny $\mathrm{P}$. Role of MICA in the immune response to transplants. Tissue Antigens. 2010;76(3):171-6.

Zou Y, Stastny P. Antibodies against major histocompatibility complex class I-related A in transplant recipients. Chin Med J. 2011;124(5):764-70. 


\section{Appendix}

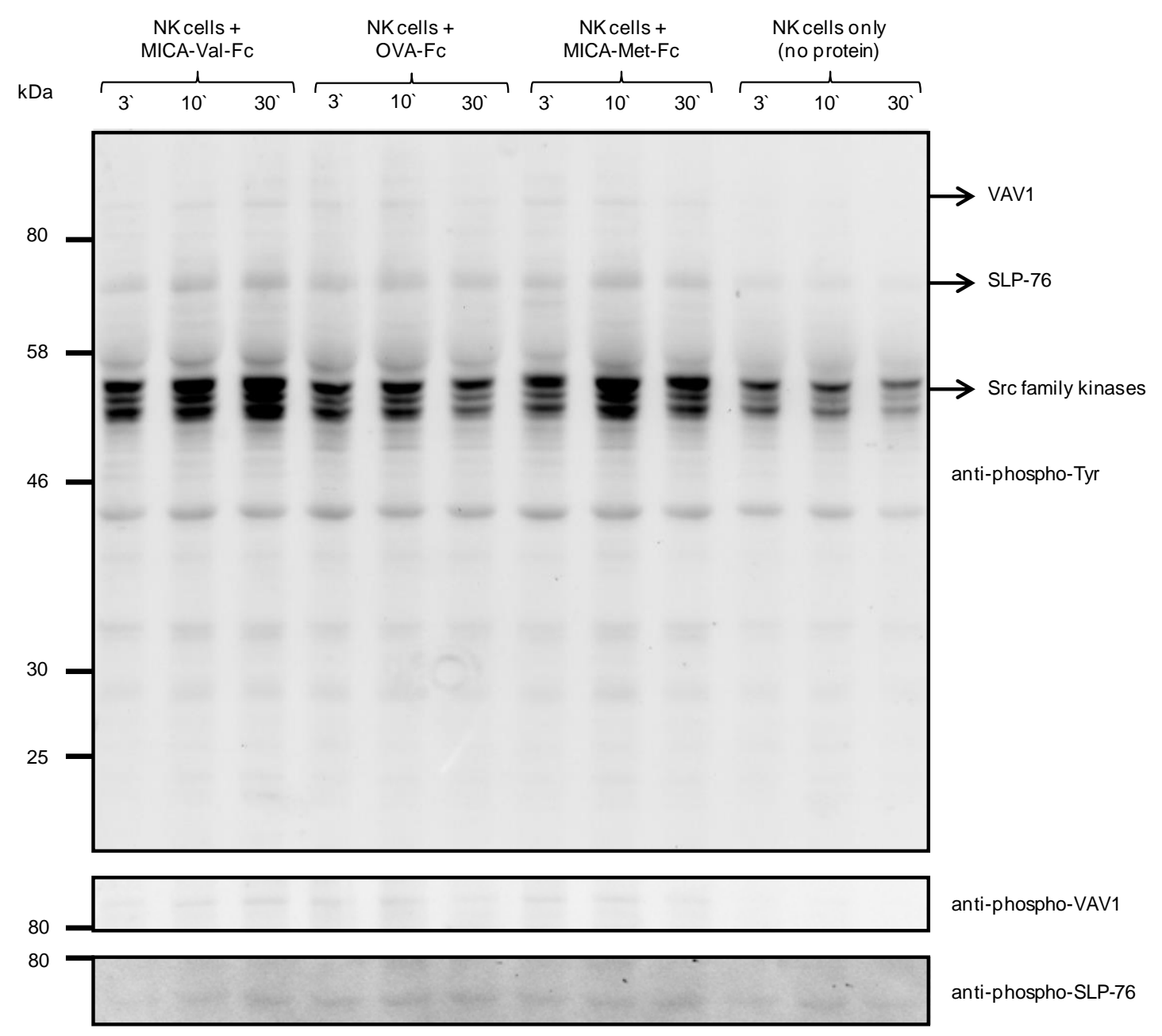

46

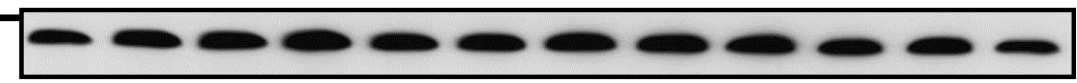

anti- $\beta$-Actin

Figure A.1: NKG2D-mediated phosphorylation of Src family kinases in response to the MICA-129Met-FC protein is faster than in response to the MICA-129Val-Fc protein.

Purified IL-2-stimulated (100 U/ml for 4 days) human NK cells $\left(10^{6}\right)$ were stimulated with immobilized MICA$129 \mathrm{Met} / \mathrm{Val}-\mathrm{mlgG}_{2 \mathrm{a}}-\mathrm{Fc}$ or OVA-mlgG ${ }_{2 \mathrm{a}}$-Fc fusion proteins $(10 \mu \mathrm{g} / \mathrm{ml})$ for 3,10 or $30 \mathrm{~min}$ in microtiter plates. The protein lysates of these cells were separated by SDS-PAGE and the blot was probed with an anti-phospho-Tyr $\mathrm{mAb}$ (upper panel) and an anti- $\beta$-Actin $\mathrm{mAb}$ as loading control. After stripping of the blot membrane with $\beta$ mercaptoethanol-containing buffer, the blot was probed with different anti-phospho-specific Abs for the downstream effectors VAV1 (101 kDa) and SLP-76 (76 kDa) using an anti-phospho-VAV1 (Tyr174) and antiphospho-SLP-76 (Tyr128) Ab. 


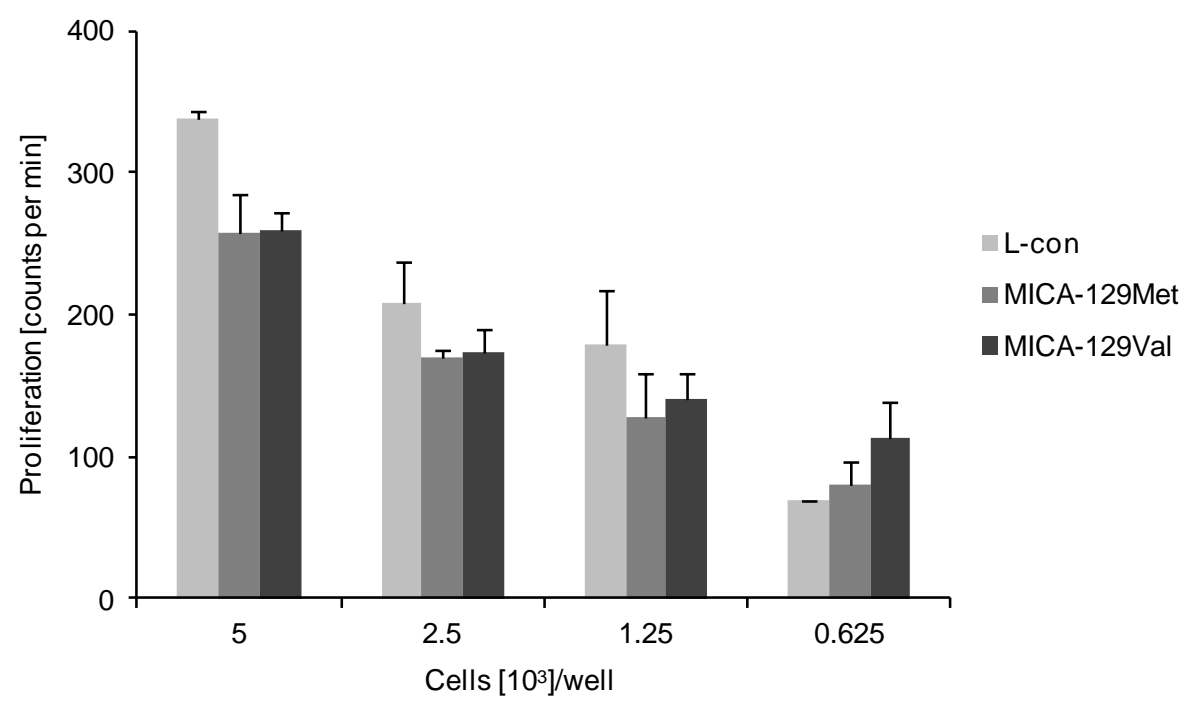

Figure A.2: Proliferation of different mouse $L$ tumor cell lines in vitro.

$\mathrm{A}^{3} \mathrm{H}$-thymidine incorporation assay was performed with L-con cells and three different clones of the L-MICA129Met $(n=3)$ and L-MICA-129Val variant $(n=3)$ to determine cell proliferation. After $24 \mathrm{~h}$ incubation under normal cell culture conditions, $1 \mu \mathrm{Ci} /$ well $^{3} \mathrm{H}$-thymidine was added to the cells and incubated for additional 24 h. Proliferation is indicated by ${ }^{3} \mathrm{H}$-thymidine incorporation (counts per min) and is shown as means of triplicates + SEM for four different cell concentrations $\left(5 \times 10^{3}, 2.5 \times 10^{3}, 1.25 \times 10^{3}\right.$ and $0.625 \times 10^{3}$ cells per $100 \mu \mathrm{l}$ medium and well) of the control cells and the two MICA-129 variants. 
A

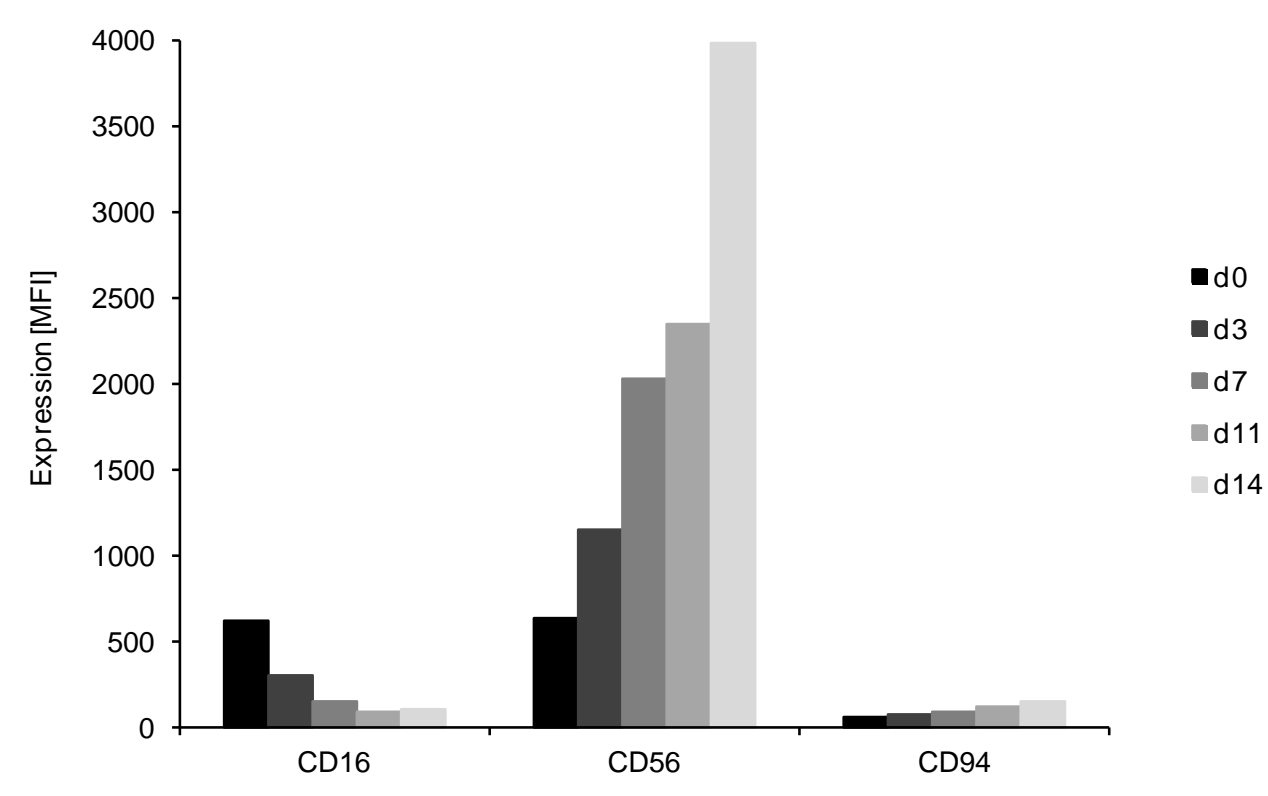

B

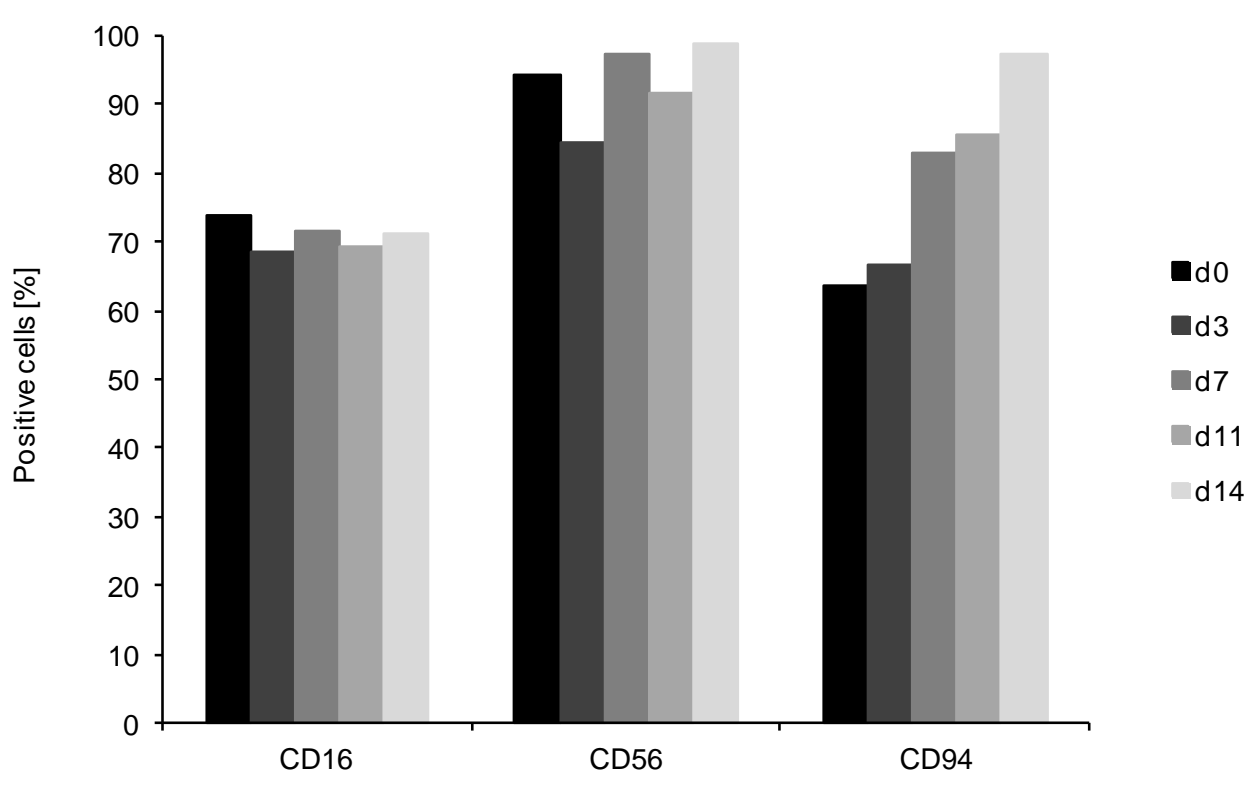

Figure A.3: Co-culture of human NK cells and irradiated human allogeneic PBMCs ('feeder cells').

MACS-isolated human NK cells were co-cultured together with irradiated human allogeneic PBMCs, so-called 'feeder cells', and $250 \mathrm{U} / \mathrm{ml} \mathrm{IL-2} \mathrm{for} 2$ weeks. (A) The MFI of the three NK cell marker CD16, CD56 and CD94 (B) and the percentage of NK cells positive for these cell surface markers were determined by flow cytometry at day (d)0 directly after MACS-isolation and at d3, d7, d11 and d14 of co-culture. 
Table A.1: Genotyping and analysis of the MICA mRNA expression of human tumor cell lines.

\begin{tabular}{|c|c|c|c|}
\hline Cell line & MICA-129 genotype & $n^{5}$ & $\begin{array}{l}\text { Relative MICA gene expression [\%] } \\
\text { mean } \pm \text { SEM }\end{array}$ \\
\hline A375II $\left(\mathrm{Mel}^{1}\right)$ & Met/Val & 2 & $10.71 \pm 1.37$ \\
\hline$+\mathrm{SAHA}^{4}$ & & 1 & 113.55 \\
\hline Ge (Mel) & Met/Val & 2 & $11.31 \pm 0.57$ \\
\hline + SAHA & & 1 & 77.56 \\
\hline HT144 (Mel) & Met/Val & 2 & $360.74 \pm 83.08$ \\
\hline + SAHA & & 1 & 421.83 \\
\hline Juso (Mel) & Val/Val & 2 & $391.12 \pm 40.57$ \\
\hline + SAHA & & 1 & 813.04 \\
\hline Malme (Mel) & Met/Met & 2 & $5.52 \pm 1.76$ \\
\hline + SAHA & & 1 & 205.15 \\
\hline Mel Ei (Mel) & Met/Val & 2 & $37.72 \pm 13.68$ \\
\hline + SAHA & & 1 & 227.63 \\
\hline Mel Ho (Mel) & Met/Val & 2 & $13.42 \pm 2.84$ \\
\hline + SAHA & & 1 & 86.25 \\
\hline Mel Im (Mel) & Met/Val & 2 & $16.36 \pm 0.10$ \\
\hline + SAHA & & 1 & 122.26 \\
\hline Mel La (Mel) & Met/Val & 2 & $115.43 \pm 22.12$ \\
\hline + SAHA & & 1 & 253.15 \\
\hline Mel Wei (Mel) & Met/Val & 2 & $126.01 \pm 34.20$ \\
\hline + SAHA & & 1 & 297.59 \\
\hline Parl (Mel) & Val/Val & 2 & $43.78 \pm 4.19$ \\
\hline + SAHA & & 1 & 442.80 \\
\hline Sk Mel-29 (Mel) & Met/Val & 2 & $10.77 \pm 1.05$ \\
\hline+ SAHA & & 1 & 121.14 \\
\hline WM266-4 (Mel) & Val/Val & 2 & $120.72 \pm 0.14$ \\
\hline+ SAHA & & 1 & 509.82 \\
\hline MCF-7 $\left(\mathrm{BC}^{2}\right)$ & Met/Val & 1 & 67.99 \\
\hline+ SAHA & & 1 & 565.69 \\
\hline MDA-MB (BC) & Val/Val & 1 & 178.18 \\
\hline + SAHA & & 1 & 437.72 \\
\hline T47D (BC) & Met/Met & 1 & 59.05 \\
\hline+ SAHA & & 1 & 854.45 \\
\hline $\mathrm{K} 562\left(\mathrm{EL}^{3}\right)$ & Met/Val & 3 & 100.00 \\
\hline
\end{tabular}

1-3 The abbreviations indicate the type of cancer: Mel $=$ melanoma, $B C=$ breast cancer and $E L=$ erythroleukemia.

${ }^{4}$ The cell lines were treated with $10 \mu \mathrm{M}$ of the HDAC inhibitor SAHA for $20 \mathrm{~h}$ before analysis to increase MICA expression as described previously (Elsner et al., 2010).

${ }^{5}$ Cells were cultured and analyzed at different time points. 


\section{Curriculum vitae}

